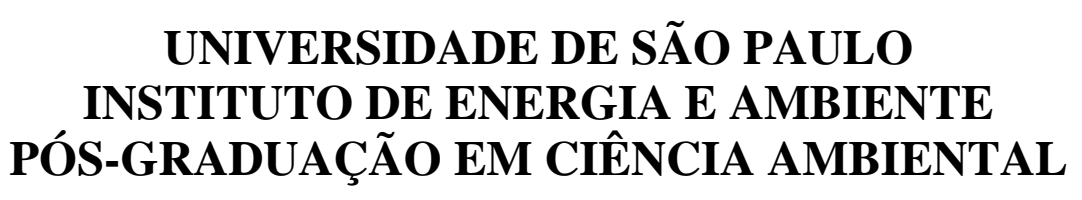

RAVI ORSINI CAMARGO DE SOUZA

VEGETARIANISMO AMBIENTAL: ESTUDO DAS CONTROVÉRSIAS NA RELAÇÃO ENTRE VEGETARIANISMO E EMISSÕES DE GASES DE EFEITO ESTUFA 


\section{VEGETARIANISMO AMBIENTAL: ESTUDO DAS CONTROVÉRSIAS NA RELAÇÃO ENTRE VEGETARIANISMO E EMISSÕES DE GASES DE EFEITO ESTUFA}

Dissertação apresentada ao Programa de PósGraduação em Ciência Ambiental do Instituto de Energia e Ambiente da Universidade de São Paulo para obtenção do título de Mestre em Ciência Ambiental.

Orientadora: Prof ${ }^{\mathrm{a}}$. Dr ${ }^{\mathrm{a}}$. Neli Aparecida de Mello Théry.

Coorientador: Prof. Dr. Stelio Alessandro Marras.

Versão Corrigida

(versão original disponível na Biblioteca do Instituto de Energia e Ambiente e na Biblioteca Digital de Teses e Dissertações da USP) 
AUTORIZO A REPRODUÇÃO E DIVULGAÇÃO TOTAL OU PARCIAL DESTE TRABALHO, POR QUALQUER MEIO CONVENCIONAL OU ELETRÔNICO, PARA FINS DE ESTUDO E PESQUISA, DESDE QUE CITADA A FONTE.

FICHA CATALOGRÁFICA

Souza, Ravi Orsini Camargo de.

Vegetarianismo ambiental: estudo das controvérsias na relação entre vegetarianismo e emissões de gases de efeito estufa. / Ravi Orsini Camargo de Souza; orientadora: Neli Aparecida de Mello-Théry; Co-orientador: Stelio Alessandro Marras. - São Paulo, 2019.

174 f.: il., $30 \mathrm{~cm}$.

Dissertação (Mestrado em Ciência Ambiental) - Programa de PósGraduação em Ciência Ambiental - Instituto de Energia e Ambiente da Universidade de São Paulo.

1. Vegetarianismo - aspectos ambientais. 2. Meio ambiente. 3. Efeito estufa. I. Título. 
Nome: SOUZA, Ravi Orsini Camargo de

Título: Vegetarianismo ambiental: estudo das controvérsias na relação entre vegetarianismo e emissões de gases de efeito estufa

Dissertação apresentada ao Instituto de Energia e Ambiente da Universidade de São Paulo para obtenção do título de Mestre em Ciência Ambiental.

Aprovado em:

\section{Banca Examinadora}

Prof. Dr.

Instituição:

Julgamento:

Prof. Dr.

Instituição:

Julgamento:

Prof. Dr.

Instituição:

Julgamento:

Prof. Dr.

Instituição:

Julgamento: 


\section{AGRADECIMENTOS}

Primeiramente, gostaria de deixar claro que estes parágrafos não conseguem, de fato, expressar o quanto é necessário agradecer a todos que contribuíram para este trabalho. Se há algum mérito no mesmo, não é só fruto de meu esforço individual de pesquisa, reflexão e escrita, mas também, de uma rede de pessoas maravilhosas que tive a felicidade que me cercasse.

Agradeço primeiramente a Deus, Krishna, à Mãe Natureza, Bhumidevi, aos espíritos e entidades, ao cosmos, ao acaso, ou seja lá quais forças possam ter atuado para me inspirar, conduzir e manter durante essa trajetória. Minhas mais sinceras, humildes e respeitosas reverências.

À minha amada companheira Patrícia Muniz, por todo o carinho, amparo, atenção, compreensão, paciência, felicidade, cuidado, delicadeza, inspiração, por ter sido um porto seguro para mim e por ter me segurado em momentos em que nem eu mesmo conseguia. Não há como listar uma quantidade incomensurável de manifestações de amor em um só parágrafo, apenas posso resumir lhe agradecendo por ser a companheira e amiga mais dedicada e feliz que uma alma pode ansiar.

À minha orientadora, Prof. ${ }^{a}$ Dr. ${ }^{a}$ Neli Aparecida de Mello-Théry, por ter aceitado me guiar nesta jornada, pelos incontáveis conselhos, correções, reuniões, instruções, ensinamentos, por todo o apoio emocional, pelos maravilhosos momentos compartilhados e todas as demais formas de dedicação que me foram concedidas com tanto profissionalismo, carinho e generosidade. Ao meu coorientador, Prof. Dr. Stelio Alessandro Marras, por também ter aceitado ser parte deste trabalho, pelas orientações, compreensão e pelo grande apoio intelectual com toda a sensibilidade e percepção antropológica que enriqueceu esta pesquisa e minha visão de mundo.

Aos meus queridos pais, Rita de Cássia e José Ruy, por todo o apoio, carinho e compreensão durante estes anos e, especialmente, por terem me dado muito do que me motivou, em minha criação, a seguir os caminhos que hoje sigo. A meus amados irmãos Nrishinro, Caitanya, Vrinda, Ananda e Nimay, por agregarem tantas coisas belas e momentos maravilhosos em minha vida, pelas risadas, carinho, atenção e muitos outros fatores que foram essenciais para meu coração, especialmente nos últimos anos. À minha querida cunhada, Priscila Almeida, por toda a amizade, apoio, gargalhadas e pelo auxílio com as correções e leituras finais. 
Aos meus amigos, dos quais tanto me orgulho, em especial Guilherme Ranieri, Danilo Sato, Paulo Paiva, Henrique Capati, Henrique Marques, Willian Emerson e Bruno Avellar e Felipe Borges, que foram de grande ajuda para a execução deste trabalho e do mestrado como um todo, com diversas discussões, trocas intelectuais, pensamentos, referências de leitura, além do carinho fraternal ao longo de todo o processo. Também agradeço especialmente a todos os amados amigos, que me apoiaram de alguma forma, me acompanharam e nutriram com tantos momentos maravilhosos, trocas genuínas, gargalhadas e tanto carinho: Aretha Araújo, Gilberto Basseto, Maria Claudia, Laura Luíza, Aline Shirazi, Fabiana Bunemer, Renata Araújo, Ivy Marie, Maíra Maidi, Janaína Pinheiro, Alexandre Souza, Tom Keiji, Regina Nery, Marcelo Augusto, Amanda Cseh, Ana Lúcia Spíndola, Isabella Vallin, Gabriel Trettel, Ernesto Nunes, Tânia Mendonça, Clara Jacq, Julianne Nestlehner, Stella Legnaioli, Juliana Delgado, André Barbosa, Jéssica Palma, Filipe de Oliveira, Marcos Vinícius, Valdir Lamim-Guedes, Carlos Gontijo e à querida Virgínia Bianchi, que se eternizou e deixará saudades, dentre muitos outros cujo nome possa ter esquecido.

À minha querida avó, Terezinha Orsini, pelas orações. Aos meus tios e primos, pelas conversas, dicas e todo o estímulo, além de meu sobrinho Kalki e todos aqueles que me aceitaram, com o coração aberto, como parte de suas famílias e me auxiliaram nos últimos anos, em especial, Isac Muniz e família, Ana Beatriz e Marcia Andréia.

Ao Conselho Nacional de Desenvolvimento Científico e Tecnológico (CNPq), pelo apoio financeiro concedido.

Aos membros das bancas de qualificação e defesa, Prof. ${ }^{a}$ Dr. ${ }^{a}$ Elaine de Azevedo, Prof. ${ }^{a}$ Dr. ${ }^{a}$ Tatiana Gomes Rotondaro e Prof. Dr. Andrea Cavicchioli, pelas valorosas contribuições e avaliação deste trabalho.

Aos professores queridos, especialmente do curso de Gestão Ambiental da Escola de Artes Ciências e Humanidades da USP e do PROCAM, que auxiliaram com preciosas dicas, aulas, muitas conversas, boas referências de leitura e por fazerem parte da minha formação.

À Dr. ${ }^{a}$ Aliane Zappia, à Dr. ${ }^{a}$ Luiza Savietto, à Dr. ${ }^{a}$ Juliana Moraco e ao Dr. Jairo Degenszajn, por ajudarem a cuidar da minha mente e corpo ao longo de todo o processo.

A todos que me auxiliaram na Sociedade Vegetariana Brasileira, aos funcionários do Intituto de Energia e Ambiente, às queridas Suely Bassi e Mirian Mayumi da UMAPAZ, aos colegas do Intituto de Estudos Brasileiros e da Faculdade de Filosofia, Letras e Ciências Humanas e, sobretudo, todos os queridos amigos e colegas da Escola de Artes Ciências e Humanidades.

Sou muito grato a todos vocês. 
“Pobres humanos... Escravos de seus próprios sonhos e presos pelos grilhões do ceticismo, eles são incapazes de vislumbrar e sentir a imensidão da verdadeira não-realidade que os rodeia. Certos de sua superioridade genética, os homens desconhecem as forças motrizes do Universo e julgam-se filhos das estrelas por terem pisado em solo lunar. Tolos pretensiosos... A Mãe-Terra aconchega outros animais muito mais interligados ao nicho macrocósmico. Os insetos e suas regras sociais quase geométricas. As aves e seu instinto de vôo em plena harmonia com o magnetismo polar. Os mamíferos aquáticos e seus mistérios inimagináveis. Tantos exemplos da irracionalidade superior, construídos sobre o primitivismo da Criação." 


\section{RESUMO}

SOUZA, Ravi Orsini Camargo de. Vegetarianismo ambiental: estudo das controvérsias na relação entre vegetarianismo e emissões de gases de efeito estufa. 2019. 174 f. Dissertação (Mestrado em Ciência Ambiental) - Instituto de Energia e Ambiente, Universidade de São Paulo, São Paulo, 2019.

Cada vez mais pessoas estão se tornando adeptas do vegetarianismo em diversos locais do mundo, incluindo o Brasil. Justificativas de caráter ambiental figuram entre as principais motivações para a adoção desta dieta, a qual é considerada por muitos como uma forma de alimentação mais sustentável. Isso se deve ao fato de que a indústria pecuária tem sido apontada como uma das contribuintes mais significativas para muitos dos grandes problemas socioambientais modernos. Paralelamente, há um crescente debate, marcado por controvérsias, sobre o impacto da produção animal, em escalas e lógicas industriais atuais, no aquecimento global antropogênico e, além disso, sobre como uma redução no consumo de alimentos de origem animal poderia contribuir para a mitigação das mudanças climáticas. As declarações, opiniões e argumentos em torno do assunto mostram discordâncias em vários aspectos e em diversos âmbitos, inclusive acadêmico, se entrelaçando em um debate interdisciplinar que envolve estimativas de emissões da pecuária industrial, possibilidades e limitações na adoção de dietas baseadas em plantas, comparativos entre eficiências energéticas e ecológicas, implicações hipotéticas de alterações nos sistemas de criação de animais convencionais, padrões e tendências no consumo de carne, questões de segurança alimentar e nutricional, dentre outras temáticas que agregam complexidade à discussão. $\mathrm{O}$ estudo, que objetivou compreender se um "vegetarianismo ambiental" poderia auxiliar a mitigar emissões antrópicas de gases de efeito estufa, foi guiado pela metodologia da cartografia de controvérsias sociotécnicas, que possibilitou identificar e revisar os tópicos mais importantes em toda a discussão, bem como as principais subcontrovérsias e argumentos que a compõe, especialmente no que diz respeito ao conhecimento científico.

Palavras-chave: Vegetarianismo. Meio ambiente. Controvérsias. Gases de efeito estufa. 


\begin{abstract}
SOUZA, Ravi Orsini Camargo de. Environmental vegetarianism: a study of the controversies in the relation between vegetarianism and the greenhouse gases emissions. 2019. 174 f. Dissertação (Mestrado em Ciência Ambiental) - Instituto de Energia e Ambiente, Universidade de São Paulo, São Paulo, 2019.

People have increasingly been becoming vegetarian all over the world, including Brazil. Environmentally-oriented justifications figure amongst the main motivations for the adoption of this diet, which is considered by many as a more sustainable eating habit. This is due to the fact that the animal industry has been pointed out as one of the most substantial contributor for many of the current large socio-environmental problems. Concurrently, there is an increasing debate, characterized by controversies, about the impact of animal production, in the current logics and dimensions, in anthropogenic global warming and, besides that, about how a decrease in the consumption of animal products could contribute for the mitigation of climate change. The declarations, opinions and arguments regarding the subject show discrepancies in many aspects and in many spheres, including the academic, intertwining in an interdisciplinary debate which involves animal farming emission estimates, possibilities and limitations in the adoption of plant based diets, comparatives between energetic and ecologic efficiencies, hypothetical implications of alterations in the conventional animal farming systems, patterns and tendencies in meat consumption, matters of food and nutritional security, among other matters which add complexity to the discussion. The research, which aimed to comprehend if an "environmental vegetarianism" would help mitigate greenhouse gases anthropic emissions, was guided by the methodology of sociotechnical controversies cartography, which made possible to identify and review the most important topics through the entire discussion, as well as the main subcontroversies and arguments which compose it, especially concerning the scientific knowledge.
\end{abstract}

Keywords: Vegetarianism. Environment. Controversies. Greenhouse gases. 


\section{LISTA DE FIGURAS}

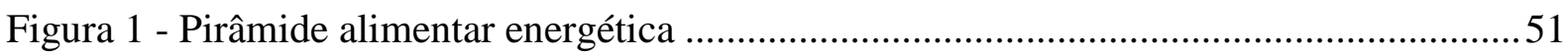

Figura 2 - Uso das terras agricultáveis do planeta............................................................57

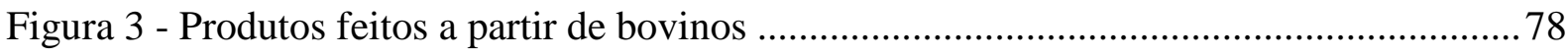

Figura 4 - Emissões de GEE por diferentes setores econômicos ............................................90

Figura 5 - Emissões de GEE no Brasil, por atividade econômica em 2015 ............................ 92

Figura 6 - Bandas de absorção de infravermelho dos principais GEE ...................................96

Figura 7 - Emissões de GEE por setores econômicos com diferentes valores de GWP ..........97

Figura 8 - Comparativo de emissões de GEE de diferentes alimentos e dietas em função de

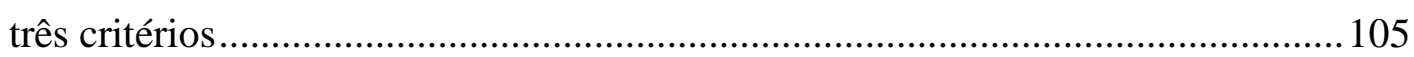

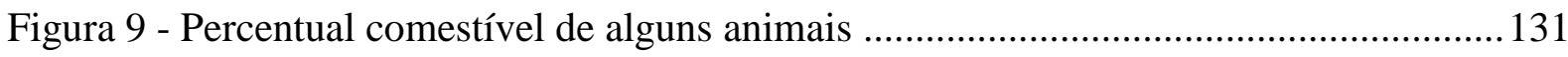

Figura 10 - Hambúrguer feito de larvas bicho-da-farinha (Tenebrio molitor) ........................ 132

Figura 11 - Primeiro hambúrguer produzido em laboratório ................................................... 133

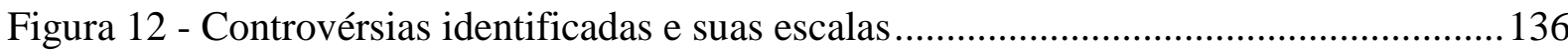




\section{LISTA DE QUADROS}

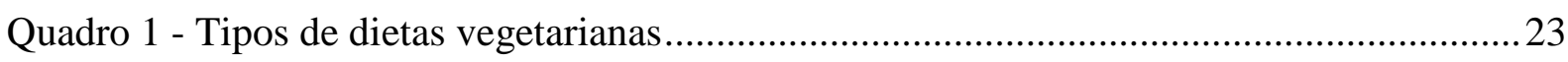

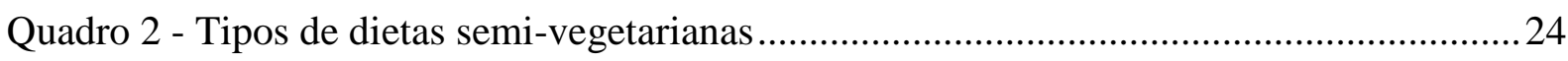

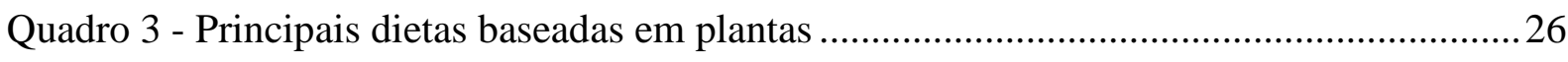

Quadro 4 - Possíveis obstáculos e limitações na transição para dietas baseadas em plantas .119

Quadro 5 - Estratégias de mitigação das emissões da pecuária ligadas aos processos

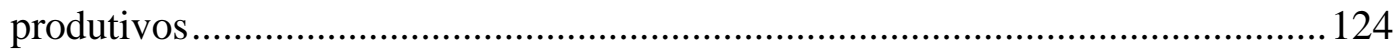




\section{LISTA DE TABELAS}

Tabela 1 - Percentuais de vegetarianos em alguns países

Tabela 2 - Participação do BNDES no capital de empresas relacionadas com a produção animal e em fundos de investimento do agronegócio 68

Tabela 3 - Custo para o capital natural em diferentes atividades econômicas no Brasil 76

Tabela 4 - Possíveis cenários de mudança do clima para 2100. 85

Tabela 5 - Percentuais das emissões antrópicas de GEE atribuídos à pecuária em diferentes estudos

Tabela 6 - Possíveis benefícios globais obtidos mudanças nos padrões de consumo de alimentos de origem animal até 2050 


\section{SUMÁRIO}

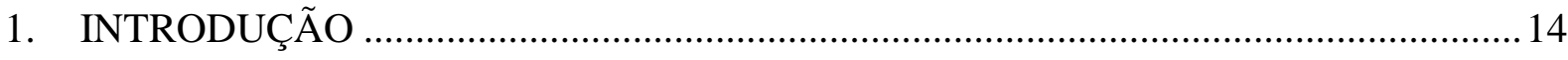

2. O VEGETARIANISMO E SUA DIMENSÃO SOCIOAMBIENTAL ........................... 22

2.1. Vegetarianismos: definições, classificações e estabilizações ...................................22

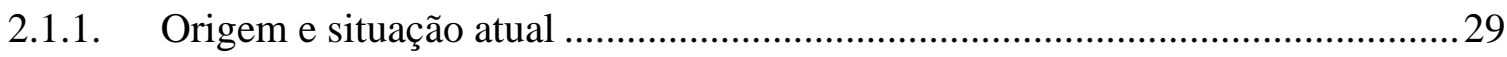

2.1.2. Motivações e discussões que transcendem a dieta .............................................. 32

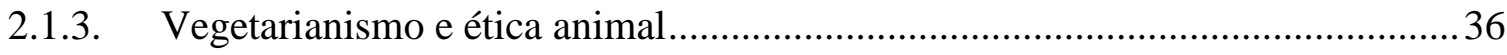

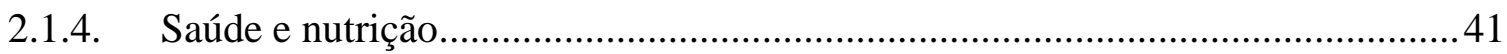

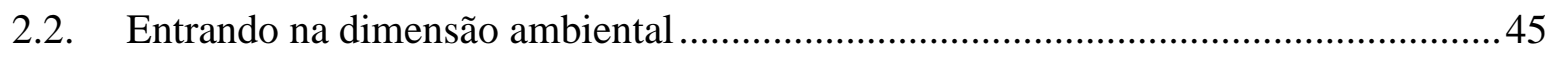

2.2.1. Conexões parciais do vegetarianismo ambiental na história humana .................46

2.2.2. Aspectos ecológicos e eficiência energética..................................................... 49

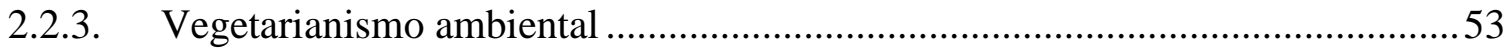

2.2.4. Justificativas e relevâncias científicas do vegetarianismo ambiental: problemas

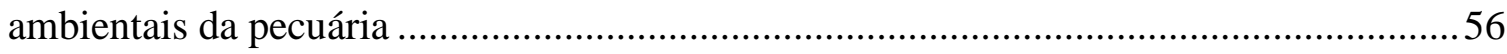

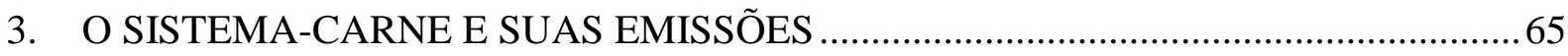

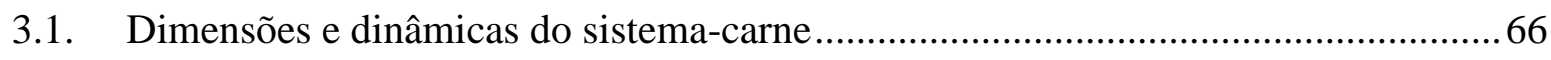

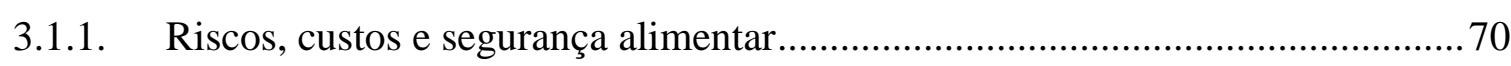

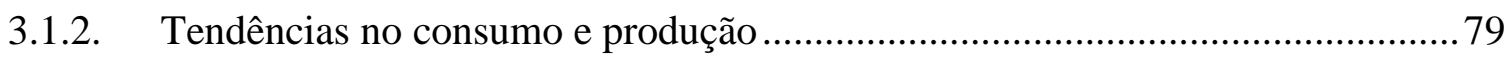

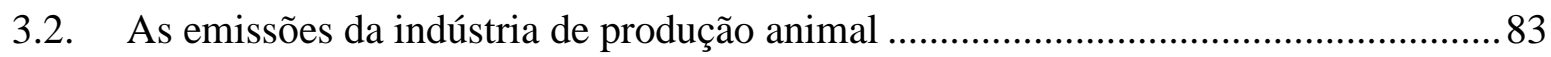

3.2.1. Gases de efeito estufa na pecuária brasileira .................................................. 91

3.2.2. Metano, óxido nitroso e os potenciais de aquecimento global .......................... 95

3.2.3. Mudanças no uso do solo, produção de forragem e outras emissões indiretas .. 98

4. VEGETARIANISMO, DIETAS BASEADAS EM PLANTAS E OUTRAS ALTERNATIVAS: POTENCIAIS, LIMITAÇÕES E CONTROVÉRSIAS ....................... 101

4.1. Potenciais de dietas baseadas em plantas para reduzir emissões ............................ 102

4.1.1. Limitações e críticas: da importância e cultura da carne ao poder do agronegócio

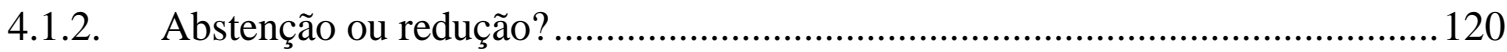

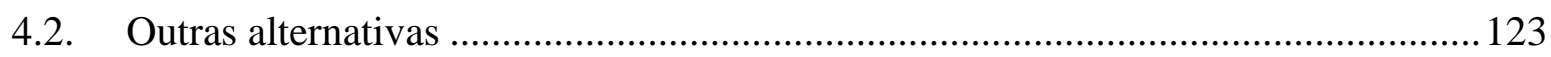

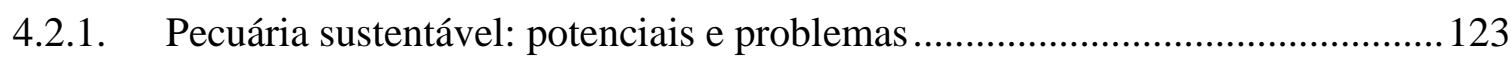

4.2.2. Consumo de carnes menos impactantes .................................................... 128

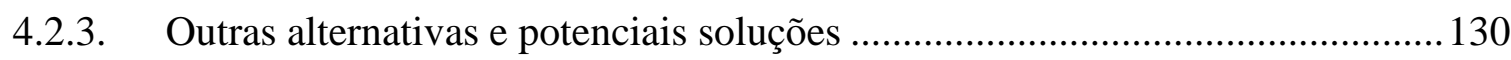

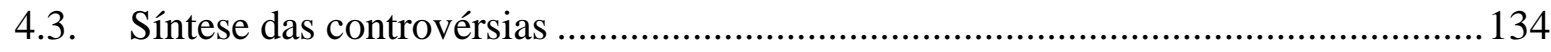




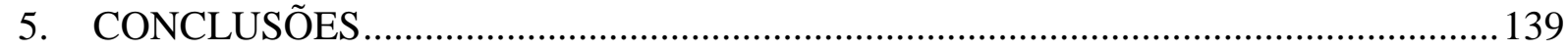

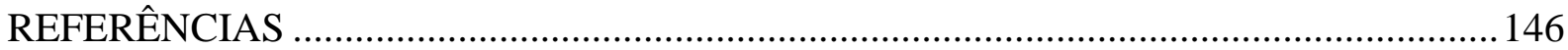




\section{INTRODUÇÃO}

A forma como nos alimentamos está diretamente relacionada ao meio ambiente. Diferentes dietas, bem como os respectivos sistemas produtivos que as suprem, afetam de maneiras distintas, não somente a saúde humana, mas a segurança alimentar e nutricional, a economia, a cultura das populações e os grandes problemas socioambientais modernos (BURLINGAME, 2010). Dentro desse contexto, um dos aspectos mais criticado e discutido nos últimos anos é a ingestão de alimentos de origem animal, principalmente da carne (ESTEVE, 2017; POLLAN, 2006).

Com base em motivações de múltiplas naturezas, um número cada vez maior de pessoas tem adotado dietas vegetarianas em muitos países, incluindo o Brasil (INSTITUTO BRASILEIRO DE OPINIÃO PÚBLICA E ESTATÍSTICA, 2018). O debate sobre a opção entre o consumo e o não-consumo de alimentos de origem animal em nossa dieta vem crescendo, tanto na academia (RUBY, 2012), quanto na sociedade de modo geral, o que tem gerado conflitos (ABONIZIO, 2016), controvérsias, incertezas e instabilidades em diversas esferas (SORDI, 2013). Dentro dessa discussão, questões socioambientais figuram como um fator importante, levando em conta que são uma das principais justificativas para o vegetarianismo (FOX; WARD, 2008; MISHORI, 2017; SOUZA, 2017) e que, além disso, a pecuária industrial moderna tem sido apontada como um dos setores que mais causam impactos ambientais em todo o planeta (FOOD AND AGRICULTURE ORGANIZATION OF THE UNITED NATIONS, 2006).

A concepção desta pesquisa surgiu a partir da união entre o interesse pessoal e familiaridade do autor com o vegetarianismo e sua formação acadêmica em Gestão Ambiental. Além disso, um crescente interesse por controvérsias científicas, bem como as discussões sobre paradigmas, reflexividade e interdisciplinaridade dentro de temáticas ambientais, também contribuíram para o recorte temático e as escolhas metodológicas realizadas.

O presente trabalho objetivou, inicialmente, explorar a temática do vegetarianismo ambiental sob o ângulo das suas controvérsias sociotécnicas. Contudo, devido a amplitude de tópicos que podem ser abordados quando consideramos questões ambientais, a partir do ponto em que a relação entre vegetarianismo e meio ambiente é estabelecida, o estudo foca no tema 
das mudanças climáticas, mais especificamente na mitigação de emissões de gases do efeito estufa relacionados à alimentação.

Poderia o vegetarianismo contribuir para reduzir emissões de gases do efeito estufa? Principalmente no Brasil, país marcado pela pecuária bovina extensiva com grande impacto ambiental, a qual é responsável por grande parcela das emissões nacionais, essa pergunta torna-se relevante. Entretanto, devido à grande importância que alimentos de origem animal possuem na cultura, economia, dieta e em diversos outros aspectos da população brasileira, colocar em cheque a produção e consumo de animais traz consigo controvérsias, dividindo opiniões inclusive no âmbito acadêmico (AZEVEDO, 2013; SORDI, 2013).

Pela natureza controversa do assunto, o presente estudo foi guiado pela Cartografia de Controvérsias $(\mathrm{CC})^{1}$, metodologia desenvolvida pelo antropólogo, sociólogo e filósofo da ciência Bruno Latour, cujo foco de investigação são as controvérsias sociotécnicas², particularmente no âmbito científico. A CC surge como uma versão didática - e, portanto, simplificada - da Teoria-Ator-Rede (TAR) (VENTURINI, 2010a). A TAR é uma corrente de teoria social da área de Estudos da Ciência e Tecnologia, que explica a formação de novos paradigmas e institui princípios para compreendê-los e estuda-los (LATOUR, 2005; LAW; HASSARD, 1999). Também chamada de "Sociologia da Tradução", foi desenvolvida na década de 80, a partir dos estudos de Michel Callon, Bruno Latour, John Law, Madelaine Akrich, dentre outros pesquisadores. Desta teoria derivam todos os princípios observados pela $\mathrm{CC}^{3}$ (FREIRE, 2006).

Trabalhos como os de Latour (2005) e Venturini (2010a, 2010b, 2015) auxiliaram a estabelecer alguns princípios que nortearam a investigação, tais como:

\footnotetext{
${ }^{1}$ Ou Mapeamento de Controvérsias Sociotécnicas.

${ }^{2}$ Podem ser referidas como "sociotécnicas", pois tratam-se de controvérsias que envolvem e confundem, em uma mesma trama, questões sociais (das construções, visões e signos humanos) e técnicas (da natureza "dada" e das coisas "em si").

${ }^{3}$ É necessário salientar que a CC e a TAR não são as únicas formas existentes para abordar controvérsias que envolvam conhecimento científico. Existem outras linhas de pensamento e metodologias que podem ser utilizadas para tal fim, especialmente na área dos estudos da ciência e tecnologia.

${ }^{4}$ Os artigos de Venturini (2010a, 2010b), foram desenvolvidos sob a supervisão de Bruno Latour e elaborados a partir dos principais trabalhos e autores que compõem a TAR. A importância destes dois trabalhos está em suas explicações detalhadas e, ao mesmo tempo, didáticas no que diz respeito à $\mathrm{CC}$, o que facilita não apenas a sua compreensão, mas a sua experimentação, especialmente para estudantes de áreas diferentes das ciências sociais e que não estejam familiarizados com as sutilezas teóricas da TAR. No entanto, para uma maior compreensão, outros trabalhos dos demais autores responsáveis pelo desenvolvimento da Teoria-Ator-Rede foram lidos e considerados pelo autor desta pesquisa.
} 
- Não se deve restringir a sua observação a alguma teoria ou metodologia específica:

A CC, apesar de ser essencialmente descritiva, não proíbe, nem impõe o emprego de teorias e metodologias específicas. Ao contrário: ela é aberta e estimula o uso de outras formas de observação (VENTURINI, 2010a). Tendo em vista esse princípio, no capítulo 2 desta dissertação há o esforço em contemplar diferentes metodologias que estimam a contribuição da pecuária para as emissões antrópicas de GEE.

- A observação deve contemplar o maior número possível de pontos de vista:

Perspectivas de pesquisa nunca são totalmente imparciais. Apesar de alguns pontos de vista oferecerem uma visão mais ampla de certas questões, as observações não escapam de suas origens e de uma série de influências. Portanto, por mais que o trabalho seja estudado por pesquisadores e sejam utilizadas pesquisas supostamente imparciais, sua origem e parcialidade não deve ser ignorada; ao contrário, deve ser também considerada (LATOUR, 2005). Objetividade e imparcialidade podem ser desenvolvidas apenas pela multiplicação dos pontos de observação. Obviamente que, por parte do pesquisador, na construção do trabalho, espera-se a busca pelo maior grau de imparcialidade possível, mas, por conta disso, a CC encoraja, além do ponto de vista que busca imparcialidade adotada pelo pesquisador, a exploração e descrição do maior número possível de pontos de vista parciais. Em resumo, quanto mais numerosa e parcial são as perspectivas em que um fenômeno é considerado, mais objetiva e imparcial será sua observação. Isto é conhecido como "objetividade de segundo grau" (VENTURINI, 2010a). Tal princípio justifica o fato de que, apesar da maioria dos estudos abordados nesta dissertação se tratarem de trabalhos acadêmicos ou de instituições científicas internacionalmente reconhecidas, apresento ao longo do trabalho relatórios de instituições vegetarianas, declarações de autores da indústria que defendem o consumo de carne, dentre outras opiniões de atores que possuem outros interesses, específicos e visíveis.

- Deve-se ouvir as vozes dos atores mais do que suas próprias presunções:

Nunca devemos negligenciar ou desconsiderar observações ou ideias de nenhum dos atores. Tal colocação é fundamental para a CC. Um participante de um fenômeno pode, perfeitamente, ser mais informado do que o próprio pesquisador que estuda este fenômeno. Sendo assim, negligenciar ideias e observações dos atores envolvidos 
apenas por não serem baseadas em metodologia científica, é, no mínimo, arrogância (VENTURINI, 2010a). Este princípio é válido não apenas nas ciências sociais, mas também para as naturais. Negligenciar o ponto de vista dos atores pode prejudicar muito a investigação científica. Segundo as ideias de Latour (2001), o conhecimento científico não é uma substância pura e absoluta, retirada do caos coletivo. Basta observar diversos casos da história da ciência para perceber a falha dessa perspectiva positivista, de uma ciência completamente purificada e imparcial, e do próprio conceito de modernidade em nossa sociedade, que está baseado em tal perspectiva (LATOUR, 2009). Esse princípio influenciou significativamente a elaboração desta dissertação, no sentido de incluir observações, declarações, opiniões e raciocínios cujo autor desta pesquisa discorda, visando respeitar outras visões de mundo e valorizar a diversidade de pensamento.

\section{- As descrições devem ser realizadas de maneira recursiva:}

Novas informações podem não apenas enriquecer, mas transformar as descrições. Logo, é importante para a CC que haja sempre a abertura para modificações (VENTURINI, 2010b). Ao longo da elaboração desta dissertação, diversas correções foram realizadas visando proporcionar descrições mais fidedignas das perspectivas abordadas.

- É preciso simplificar a complexidade de uma maneira respeitosa e representativa:

A realidade envolvendo uma controvérsia geralmente envolve uma grande quantidade de informações e relações que se apresenta de forma complexa. Para ser possível descrever controvérsias em qualquer trabalho (que possui prazos e limitações) é preciso realizar simplificações de forma representativa, evitando causar grandes distorções.

Para definir a visibilidade dos pontos de vista expostos neste trabalho, foram levados em conta três fatores descritos por Venturini (2010b), que definem critérios para a proporcionalidade entre diferentes pontos de vista em um trabalho: representatividade, influência e interesse. A partir destes critérios e princípios estabelecidos pela CC, foi possível realizar uma revisão bibliográfica do tema e, por fim, estruturar esta dissertação em três capítulos que exploram a relação entre vegetarianismo e meio ambiente, com o posterior foco na questão das emissões de GEE. 
1. Representatividade: significa levar em conta o número de participantes que subscrevem e reproduzem um determinado ponto de vista. Nem todas as perspectivas são consideradas de forma igual. O espaço de uma declaração que é compartilhada por múltiplos atores merece mais visibilidade do que uma que é relativamente marginal. No capítulo 3, por exemplo, fica evidente uma concordância generalizada que, via de regra, dietas baseadas em plantas estão relacionadas a menos emissões GEE que aquelas baseadas em alimentos de origem animal, pois a maioria dos trabalhos abordados compartilhava esse ponto de vista. Logo, tal perspectiva possui uma visibilidade maior.

2. Influência: o número de apoiadores de um determinado ponto de vista não é o único critério a se levar em conta. Deve-se dar atenção especial ao que é declarado por aqueles que ocupam posições de poder e influência, uma vez que estes possuem maiores capacidades de influenciar outros atores. Por conta disso, foram levados em conta as opiniões dos principais actantes dentro de assuntos específicos, por exemplo: instituições vegetarianas, quando abordadas as definições do vegetarianismo (capítulo 1), o Painel Intergovernamental sobre Mudanças Climáticas, na discussão acerca de emissões de GEE e mudanças climáticas (capítulos 2 e 3) e estudos de revistas e autores ligados à ciência ambiental, no trabalho como um todo.

3. Interesse: pontos de vista contrários e originais merecem um espaço especial. Mesmo que sejam considerados subversivos, marginais ou ainda que sejam reproduzidos apenas por minorias, é importante dar espaço para opiniões que apresentem um alinhamento diferente das demais. A própria formação de controvérsias depende do surgimento das opiniões contrárias que, geralmente, começam com as minorias. No capítulo 2, por exemplo, é possível encontrar uma descrição do ponto de vista de que a produção de carne é eficiente em termos de energia. Já no capítulo 3, é descrito um estudo em que alguns alimentos de origem vegetal emitiam mais GEE do que certos alimentos de origem animal. Tratam-se de perspectivas marginais, anedóticas ou com critérios muito específicos, as quais estão representadas e são desdobradas, ainda que com uma visibilidade menor.

É preciso salientar alguns fatores que agregam importância a este trabalho. Os debates sobre os diversos impactos ambientais gerados pela indústria de produção animal são marcados por algumas controvérsias. Enquanto, por um lado, a produção animal em grande 
escala é considerada essencial para a segurança alimentar, por outro, ela é apontada como uma forma extremamente impactante e ineficiente de se produzir alimentos. Com isso, as possíveis soluções para o problema também dividem opiniões, abordando desde mudanças nos sistemas produtivos da pecuária, regulações e taxações sobre os mercados de carne, até a modificação dos padrões de consumo de carne das populações, que é onde as Dietas Baseadas em Plantas ${ }^{5}$ e o vegetarianismo se inserem. Dadas as incertezas e instabilidades inerentes às controvérsias sociotécnicas dos temas tratados, esta pesquisa pode ser útil para auxiliar tomadas de decisões técnico-científicas e políticas que envolvam os assuntos aqui abordados.

O próprio protagonismo da produção animal de escala industrial em diversas problemáticas socioambientais modernas, sobretudo no Brasil ${ }^{6}$, também confere importância para o trabalho dentro das ciências ambientais, ainda que mudanças no consumo não representem as únicas opções possíveis para promover sistemas alimentares mais sustentáveis ${ }^{7}$.

Apesar de existirem significativos estudos em outros países, não foram encontradas pesquisas nacionais que abordem o "vegetarianismo ambiental" nesses termos ${ }^{8}$. Notou-se também a escassez de trabalhos brasileiros em outros temas que serão abordados, tais como as controvérsias entre os diferentes percentuais de emissões de GEE atribuídos à pecuária, os potenciais de mitigações, as mudanças climáticas através da abstenção do consumo de carne no Brasil, dentre outras. Ainda, é possível destacar a necessidade de mais estudos nacionais que explorem a real viabilidade política, econômica e social de ações baseadas em mudanças nos padrões de consumo de alimentos de origem animal, de modo a fomentar a sustentabilidade na produção alimentar. Não se pode deixar de lado, igualmente, fatores ligados às ciências sociais ou às ciências naturais, especialmente levando em conta que o tema estudado desvelou relações relevantes entre tópicos de diferentes áreas do conhecimento científico: desde as descrições e detalhes sobre as práticas alimentares que reduzem o consumo de carne (da sociologia da alimentação e do consumo), passando pelas disparidades energéticas existentes entre animais e vegetais (biologia e ecologia), as diferenças nos

\footnotetext{
${ }^{5}$ Tal termo será melhor descrito no capítulo 2 desta dissertação.

${ }^{6}$ Como será apresentado no item 2.2.4.

${ }^{7}$ Vide seção 4.2 .

${ }^{8}$ Com exceção de um artigo publicado recentemente pelo próprio autor desta pesquisa (SOUZA, 2017). Abordaremos melhor este conceito ao longo desta dissertação.
} 
potenciais de aquecimento global do metano (química ambiental), até certas questões macroeconômicas e políticas que influenciam o tema como um todo (economia e geografia).

A primeira seção do primeiro capítulo trata do vegetarianismo como um todo, trazendo definições, conceitos, histórico, motivações, abordando questões de natureza ética e relacionadas à saúde e nutrição, as quais não são o foco desta pesquisa, mas são relevantes quando consideramos o tema. Logo após, a partir do item 1.2 o foco passa a ser a dimensão ambiental, introduzindo o conceito de vegetarianismo ambiental e trazendo à tona um histórico de constatações empíricas, obras relacionadas ao tema, aspectos ecológicos e energéticos relevantes, além de um apanhado com diversas justificativas e suas respectivas referências científicas no que diz respeito à relevância do vegetarianismo para questões ambientais de modo geral.

O capítulo 2 se dedica a compreender a produção, mercado e consumo de animais, que é essencialmente o que está em jogo quando abordamos o vegetarianismo. É possível, portanto, dar ao leitor uma noção da dimensão e principais dinâmicas do sistema-carne ${ }^{9}$, bem como das problemáticas de segurança alimentar, custos ambientais, tendências e projeções no consumo e produção de carne. A segunda parte deste capítulo, procura mostrar qual o impacto específico da pecuária nas mudanças climáticas, com destaque na controvérsia existente entre os estudos que visam estabelecer qual a parcela total de contribuição do setor no aquecimento global antropogênico. Além disso, são abordadas as principais fontes e detalhes sobre as emissões do setor.

Uma vez abordadas as principais informações sobre GEE liberados pela indústria pecuária, bem como um panorama socioambiental geral da indústria de produção animal, o último capítulo discutirá possíveis soluções para mitigar as emissões e promover uma alimentação mais sustentável. Na primeira parte serão abordados os potenciais de Dietas Baseadas em Plantas (DPB), conceito que incluiu as dietas vegetarianas, para mitigar emissões de GEE. Também são levantadas as principais críticas, limitações e obstáculos que reduções nos padrões de ingestão de carne podem enfrentar, além de uma discussão sobre a dicotomia entre as opções de redução (flexitarianismo, dentre outras dietas semi-vegetarianas) e de abstenção (vegetarianismo e o veganismo ${ }^{10}$ ). A segunda parte aborda as soluções para

\footnotetext{
${ }^{9}$ Conceito de Lewgoy e Sordi (2012), que contempla a produção, mercado, consumo e toda a cultura que se estrutura ao redor da carne. Mais detalhes acerca do tema serão abordados ao longo do capítulo 3 desta dissertação.

${ }^{10}$ As diferenças entre "vegetarianismo" e "veganismo" serão melhor abordadas no item 2.1 desta dissertação.
} 
reduzir emissões da carne através de mudanças nos sistemas produtivos, estabelecendo os potenciais e as limitações do mesmo. Também são contempladas e discutidas outras opções, tais como um consumo de carne mais seletivo, no que diz respeito a espécies que são menos impactantes, além de outras possibilidades, como a entomofagia e a carne artificial. 


\section{O VEGETARIANISMO E SUA DIMENSÃO SOCIOAMBIENTAL}

O presente capítulo objetiva apresentar o conceito de vegetarianismo ambiental, conceito fundamental para o desenvolvimento do trabalho e para compreender como toda a discussão referente a redução do consumo de produtos de origem animal em nossa dieta se insere em questões socioambientais maiores. Logo, para explicar esta concepção e exemplificar suas principais ideias, serão apresentados os argumentos mais importantes, bem como seus respectivos embasamentos científicos ${ }^{11}$, que legitimem e demonstrem a ligação entre o "vegetarianismo" e o "ambiental".

Primeiramente, é necessário compreender as definições, classificações, delineamentos, estabilizações e justificativas que embasam o vegetarianismo, para, assim, compreender como esta prática se relaciona a questões de caráter socioambiental, muitas vezes, inclusive embasando-se nessas mesmas questões.

\subsection{Vegetarianismos: definições, classificações e estabilizações}

O termo "vegetarianismo" se refere à prática de não consumir carnes, aves, peixes ou seus subprodutos, mantendo uma dieta baseada em alimentos de origem vegetal, que pode, ou não, incluir o uso de ovos e laticínios (UNIÃO VEGETARIANA INTERNACIONAL, 2018). De acordo com o senso comum, o termo refere-se, simplesmente, a uma dieta isenta do consumo de carnes (AZEVEDO, 2013). Apesar dos delineamentos estabelecidos pelas definições, o conceito abarca uma pluralidade de sistemas alimentares diferentes, dentre os quais, podemos citar alguns como sendo os mais comuns.

O quadro a seguir (Quadro 1) apresenta algumas das principais dietas consideradas vegetarianas, juntamente a uma breve descrição dos alimentos consumidos e não consumidos em cada uma.

\footnotetext{
${ }^{11}$ É preciso ressaltar que, ainda dentro da diversidade de questões que poderíamos categorizar como ambientais, existem outras motivações que não envolvem tão fortemente discussões científicas, mas, dentro do âmbito acadêmico e de um mapeamento de controvérsias sociotécnicas, nos interessa, sobretudo, assuntos que envolvam conhecimento científico.
} 
Quadro 1 - Tipos de dietas vegetarianas

\begin{tabular}{|l|l|}
\hline \multicolumn{1}{|c|}{ Dieta } & \multicolumn{1}{c|}{ Descrição } \\
\hline Vegetarianismo estrito & $\begin{array}{l}\text { Não consome nenhum produto de origem animal na alimentação } \\
\text { (SOCIEDADE VEGETARIANA BRASILEIRA, 2018a). }\end{array}$ \\
\hline Ovolactovegetarianismo & $\begin{array}{l}\text { Não consome carnes, aves, peixes ou seus subprodutos na } \\
\text { alimentação, mas utiliza ovo, leite e laticínios (SOCIEDADE } \\
\text { VEGETARIANA BRASILEIRA, 2018a). }\end{array}$ \\
\hline Lactovegetarianismo & $\begin{array}{l}\text { Não consome carnes, aves, peixes, ovos ou seus subprodutos na } \\
\text { alimentação, mas utiliza leite e laticínios (SOCIEDADE } \\
\text { VEGETARIANA BRASILEIRA, 2018a). }\end{array}$ \\
\hline Ovovegetarianismo & $\begin{array}{l}\text { Não consome carnes, aves, peixes, ou seus subprodutos na } \\
\text { alimentação, mas utiliza ovos (SOCIEDADE VEGETARIANA } \\
\text { BRASILEIRA, 2018a). }\end{array}$ \\
\hline
\end{tabular}

Fonte: Elaborado pelo autor.

Ainda existe o conceito de "semi-vegetarianismo", que é utilizado tanto na literatura científica (DE BACKER; HUDDERS, 2014; HEINRICH BÖLL FOUNDATION, 2014; LACOUR et al., 2018; MULLEE et al., 2017; PERRY; GRACE, 2015; ROTHGERBER, 2014), quanto por organizações vegetarianas (SLYWITCH, 2012) e pela mídia de modo geral (TAYLOR, 2012). A definição é utilizada para enquadrar indivíduos que comem carne em quantidades reduzidas $^{12}$, mas que não são vegetarianos segundo as definições mais aceitas (SLYWITCH, 2012). Algumas das principais dietas semi-vegetarianas estão descritas no Quadro 2, apresentado a seguir. Ainda que exista tal categoria, existem muitos semivegetarianos que frequentemente se autodeclaram vegetarianos, enquanto seus hábitos alimentares continuam incluindo o consumo de "carne que não tem cara de carne"13 (SORDI, 2013).

Apesar de ser possível identificar certo consenso internacional ${ }^{14}$ nas definições mostradas pelos Quadros 1 e 2, é preciso salientar que o que é considerado "vegetarianismo"

\footnotetext{
${ }^{12}$ Valores de referência encontrados são de uma ingestão de carne branca até 3 vezes por semana (SLYWITCH, 2012) ou, ainda, com um consumo ocasional de carnes, de quaisquer tipos, que seja de 1 a 2 vezes por semana (CONSELHO REGIONAL DE NUTRICIONISTAS, 2015).

13 Alimentos que são constituídos majoritariamente de tecido animal, mas cuja aparência não remete à carne, devido ao seu processo de processamento, transformação e preparação (SORDI, 2013).

${ }^{14}$ Por parte das organizações vegetarianas estudadas, suas respectivas produções e em trabalhos acadêmicos abordados nesta pesquisa.
} 
pode variar de acordo com o local, cultura em questão ${ }^{15}$ e até mesmo dentro de uma só região, como mostra, por exemplo, o trabalho de Subramaniam (2011).

Quadro 2 - Tipos de dietas semi-vegetarianas

\begin{tabular}{|l|l|}
\hline \multicolumn{1}{|c|}{ Dieta } & \multicolumn{1}{c|}{ Descrição } \\
\hline $\begin{array}{l}\text { Flexitarianismo ou } \\
\text { reducitarianismo }\end{array}$ & $\begin{array}{l}\text { Consome carne, ovos, leite e laticínios na alimentação } \\
\text { ocasionalmente, ou seja, em taxas reduzidas, além dos } \\
\text { alimentos de origem vegetal (BRIAN, 2017; DE BOER; } \\
\text { SCHÖSLER; AIKING, 2014; HEINRICH BÖLL } \\
\text { FOUNDATION, 2014). }\end{array}$ \\
\hline $\begin{array}{l}\text { Pescetarianismo } \\
\text { Pescovegetarianismo, ou } \\
\text { piscovegetarianismo) }\end{array}$ & $\begin{array}{l}\text { Consome peixes e frutos do mar em sua alimentação, além dos } \\
\text { alimentos de origem vegetal, mas não utiliza outros tipos de } \\
\text { carnes (SLYWITCH, 2010). }\end{array}$ \\
\hline Pollovegetarianismo & $\begin{array}{l}\text { Consome aves em sua alimentação, além dos alimentos de } \\
\text { origem vegetal, mas não utiliza outros tipos de carnes ou peixes } \\
\text { (SLYWITCH, 2010). }\end{array}$ \\
\hline
\end{tabular}

Fonte: Elaborado pelo autor.

Há, ainda, a necessidade de descrever o fenômeno paralelo do "veganismo", que, frequentemente é confundido com o vegetarianismo ${ }^{16}$. O veganismo possui um relação clara e paralela com o vegetarianismo, no entanto, não podem ser dados como sinônimos, uma vez que o ethos do primeiro transcende o aspecto alimentar (NUNES, 2010; SOCIEDADE VEGETARIANA BRASILEIRA, 2018a; SORDI, 2013). De acordo com a definição da The Vegan Society, uma das maiores referências internacionais no tema, fundada em 1944, não se trata de apenas uma dieta, mas, "uma filosofia e modo de vida que procura excluir, na medida do possível e do praticável, todas as formas de exploração e crueldade com animais para alimentação, vestuário ou qualquer outro propósito" (THE VEGAN SOCIETY, 2018, tradução nossa).

Claro que, por abarcar o aspecto alimentar, todo vegano seria, em regra, um vegetariano estrito, mas, ao contrário do vegetarianismo, que pode apresentar motivações

\footnotetext{
15 Para a viabilidade desta pesquisa, apesar de certas desconstruções conceituais feitas ao longo no texto, trabalharemos a partir das definições apresentadas nos Quadros 1 e 2.

${ }^{16}$ Como, por exemplo, em um artigo de junho de 2012, publicado pelo site do Jornal Hoje, da Rede Globo, no qual houve uma confusão entre os termos "vegetariano" e "vegano" (CHAVES, 2012). Há, ainda, trabalhos acadêmicos, como o de Takeuti e Oliveira (2013), que se referem ao veganismo como sendo apenas uma "dieta". Para mais informações acerca da confusão acerca dos limites das duas práticas, vegetarianismo e veganismo, bem como suas respectivas explicações, vide os trabalhos de Sordi (2013) e de Abonizio (2013).
} 
centrais de diversas naturezas (FOX; WARD, 2008; MORTARA, 2013; ROSENFELD; BURROW, 2017; RUBY, 2012), a prática do veganismo é definida, primariamente, por contornos éticos. Além disso, o veganismo abarca diferentes aspectos da vida cotidiana e do consumo que vão além da alimentação, tais como entretenimento, vestuário, locomoção, dentre outros (NUNES, 2010; SOCIEDADE VEGETARIANA BRASILEIRA, 2018a; SORDI, 2013).

Logo, ainda que se trate de uma filosofia de vida presente em diversos locais do Brasil e do mundo e ainda que seu movimento e prática possuam diversidades e pluralidades (ABONIZIO, 2013), resumir o veganismo a uma dieta ou sistema alimentar, ou associá-lo, de forma primária ou estrutural, a motivações de outras naturezas que não a ética, é uma abordagem reducionista e equivocada. Tal conclusão é endossada tanto pelas definições em estudos sobre o veganismo (BRÜGGER, 2009; NUNES, 2010; THE VEGAN SOCIETY, 2018) quanto por seus praticantes e porta vozes ${ }^{17}$. Já no caso do vegetarianismo, as motivações não precisam estar, necessariamente, associadas a contornos éticos.

É importante, também, conhecer o conceito de "Dietas Baseadas em Plantas" (DBP). Podemos defini-lo como um regime alimentar que incentiva o consumo de alimentos integrais de origem vegetal e desestimula a ingestão de carnes, ovos, leite e derivados (TUSO et al., 2013). Apesar de suas similaridades com o vegetarianismo, é um conceito mais abrangente que, na prática, engloba tanto regimes semi-vegetarianos quanto vegetarianos ${ }^{18}$ (ROSENFELD; BURROW, 2017). O Quadro 3 apresenta o detalhamento das principais dietas que podem ser consideradas dentro deste escopo.

Voltando a atenção para a ontologia do vegetarianismo, há uma diversidade de conceitos, delineamentos e práticas que ajudam a definir as imagens identitárias e os contornos do que pode, ou não, ser considerado "vegetariano". No entanto, tal como coloca $\operatorname{Vargas}^{19}$ (2007) e Latour (2005), quando nos aproximamos e conhecemos um fenômeno de perto, as identidades ontológicas se desestabilizam, tudo se heterogeniza, decompõe em

\footnotetext{
${ }^{17} \mathrm{O}$ veganismo, como sendo uma filosofia ou modo de vida embasado e estruturado, sobretudo, por questões éticas relacionadas aos animais, é, de fato, endossado no discurso vegano brasileiro, como mostrado pelo trabalho de Nunes (2010) e em diversas entrevistas e artigos de porta vozes de organizações veganas brasileiras. Vide, por exemplo, artigo de Chaves (2018).

${ }^{18}$ Existem outras definições relevantes derivadas, tais como o "whole food, plant based diets", que diz respeito a uma alimentação integral baseada em plantas, trazendo, portanto, uma ênfase ao consumo de menos alimentos processados e modificados nutricionalmente em seus processos produtivos (TUSO et al., 2013).

${ }^{19}$ Partindo da ótica da monadologia de Gabriel Tarde (TARDE, 2007).
} 
detalhes, relações diversas e complexidade. Tanto as práticas do vegetarianismo, quanto a sua etimologia e definições, não se apresentam de forma exata, sólida ou estática, mas possuem subjetividades intrínsecas e estão em constante discussão e transformação.

Quadro 3 - Principais dietas baseadas em plantas

\begin{tabular}{|l|l|}
\hline \multicolumn{1}{|c|}{ Dieta } & \multicolumn{1}{c|}{ Descrição } \\
\hline Vegetariana estrita & Vide Quadro 1. \\
\hline Vegetariana-crudívora & $\begin{array}{l}\text { Excluem-se os mesmos alimentos que a } \\
\text { dieta vegetariana estrita, mas também não se } \\
\text { consomem alimentos cozidos a temperaturas } \\
\text { superiores à 48 }{ }^{\circ} \text { C. }\end{array}$ \\
\hline Lactovegetariana & Vide Quadro 1. \\
\hline Ovovegetariana & Vide Quadro 1. \\
\hline Ovolactovegetariana & Vide Quadro 1. \\
\hline Integral baseada em plantas ${ }^{20}$ & $\begin{array}{l}\text { Encoraja a ingestão de alimentos de origem } \\
\text { vegetal em sua forma integral, além disso, } \\
\text { limita significativamente a ingestão de } \\
\text { alimentos de origem animal. }\end{array}$ \\
\hline Mediterrânea & $\begin{array}{l}\text { Similar à dieta integral baseada em plantas, } \\
\text { mas com o consumo de frango, ovos, } \\
\text { laticínios e carne vermelha uma ou duas } \\
\text { vezes ao mês. }\end{array}$ \\
\hline
\end{tabular}

Fonte: Adaptado de Tuso et al., 2013.

Para dar um exemplo, de acordo com a etimologia do termo "vegetarianismo", é possível associar o conceito não apenas aos vegetais, mas à palavra em latim "vegetus" que significa forte, saudável e vigoroso (NUNES, 2010). Sob esse ponto de vista, acessaria outras ideias mais amplas do que uma simples relação com os vegetais. Por outro lado, Davis (2011), alega que o termo não se deriva do latim, mas, foi originalmente concebido diretamente à partir da palavra "vegetable"21 junto ao sufixo "arian", formando assim "vegetarian"22.

Apesar das definições mostradas nos quadros anteriores serem relativamente bem aceitas e replicadas ${ }^{23}$, e embora o termo "vegetariano" seja utilizado comumente para se referir a indivíduos ovolactovegetarianos e lactovegetarianos, existe uma discussão,

\footnotetext{
${ }^{20}$ Em inglês: "Whole-foods, plant-based diets".

${ }^{21}$ Da língua inglesa, que significa "vegetal".

${ }^{22}$ Vegetariano.

${ }^{23}$ Como constatado ao longo de todos os trabalhos revisados nesta pesquisa.
} 
frequentemente levantada entre os próprios vegetarianos e veganos, sobre a necessidade de utilização da palavra "estrito". Para alguns defensores deste ponto de vista, o termo "vegetarianismo", por si só, deveria remeter-se a uma dieta exclusivamente baseada em alimentos de origem vegetal ${ }^{24}$, tal como o próprio termo indicaria, não podendo ser associada ao ovolactovegetarianismo ou ao lactovegetarianismo. Além disso, há quem considere a própria definição de vegetarianismo imprecisa, já que muitas pessoas se afirmam vegetarianas, mas consomem carnes brancas e peixes (ABONIZIO, 2013).

Considerando a centralidade e a importância da palavra "vegetal" no conceito de vegetarianismo, bem como a identidade do próprio vegetariano ${ }^{25}$, é intuitiva a conclusão de que os "vegetarianos estritos" consumiriam apenas alimentos de origem vegetal ${ }^{26}$. No entanto, estes, de modo geral, também consomem alimentos do reino Fungi, tais como cogumelos comestíveis (MERCY FOR ANIMALS, 2016; SLYWITCH, 2012) e, evidentemente, alimentos considerados de origem mineral: água e sal. Tal constatação tornaria mais fraco o viés etimológico do argumento, que discorda da existência do conceito de "vegetarianismo estrito".

Dentro desta discussão, ainda é possível encontrar uma crítica direcionada aos que defendem que o "ovolactovegetarianismo" ou o "lactovegetarianismo" não poderia ser considerado uma dieta verdadeiramente "vegetariana", pelo fato de ambas estarem envolvidas com algum grau de exploração e sofrimento animal ${ }^{27}$, fato que, supostamente, não ocorreria com o vegetarianismo estrito, o "verdadeiro vegetarianismo" segundo os defensores dessa argumentação. Entretanto, basta um pouco de conhecimento dos processos produtivos da agropecuária para constatar que, dada a realidade da indústria e consumo atuais, não é possível produzir alimento de origem animal ou vegetal sem alguma morte ou sofrimento animal. Dessa forma, a reinvindicação purista de um certo vegetarianismo desvinculado, de forma absoluta, de toda exploração animal não faz tanto sentido. Mas, cabe ressaltar que isso não anula o fato de que uma dieta vegetariana pode reduzir significativamente o sofrimento e

\footnotetext{
${ }^{24}$ É possível encontrar esse debate em diversos espaços virtuais de discussão acessados por vegetarianos e veganos. Como exemplo, é possível citar um texto da página do site AtmaVeg, onde é argumentado que consumo de qualquer animal ou seus produtos derivados, tais como leite, queijos ou ovos, contraria a ideia e conceito do "vegetarismo" (ATMAVEG, 2018).

25 Descrita e exemplificada mais profundamente no trabalho de Abonizio (2016).

${ }^{26}$ Assumindo a definição biológica tradicional de "vegetal" como organismo pertencente ao reino Plantae.

${ }^{27}$ Argumento que pode ser encontrado em diversas divergência entre vegetarianos como, por exemplo, no site da AtmaVeg (2018).
} 
morte dos animais ${ }^{28}$ e, além disso, a redução nos padrões de consumo de carne pode ser um fator chave para reduzir perdas na biodiversidade futura (MACHOVINA; FEELEY; RIPPLE, 2015; NETHERLANDS ENVIRONMENTAL ASSESSMENT AGENCY, 2010), sem contar com outros benefícios socioambientais que afetam os animais direta e indiretamente. Ademais, segundo a própria União Vegetariana Internacional, o conceito de "vegetarianismo" pode, ou não, incluir o consumo de ovos, mel, leites e derivados (UNIÃO VEGETARIANA INTERNACIONAL, 2018).

Como o foco deste trabalho não é uma discussão conceitual, podemos encerrar esse tópico compreendendo parte da ontologia do vegetarianismo e tendo ciência de que este envolve uma diversidade de conceitos, com suas respectivas concepções e práticas, as quais possuem certas estabilizações ontológicas e, ao mesmo tempo, apresentam algumas controvérsias e discussões. Ainda que algumas revisões bibliográficas indiquem que o termo "vegetariano" pode ser considerado um tanto vago (ABONIZIO, 2013; RUBY, 2012), no que diz respeito às identidades e classificações dos tipo de vegetarianos. É preciso, portanto, reconhecer esse fenômeno e ter respeito às ontologias e especificidades de cada indivíduo ou grupo, especialmente no que concerne às suas autodefinições e imagens identitárias. $\mathrm{O}$ que não significa que, ao mesmo tempo, devemos deixar de prezar por alguma coerência com a realidade das práticas e com conceitos teoricamente aceitos e amplamente estabelecidos.

O ponto conclusivo em comum entre as diferentes definições e práticas tidas como "vegetarianas" é que, via de regra, trata-se de não consumir alimentos de origem animal, em especial, do grupo das carnes. Ainda que se possa, ou não, envolver questões éticas, ambientais, nutricionais, filosóficas e de outra natureza, de modo geral, o vegetarianismo diz respeito ao que se come, ou melhor: ao que não se come. Resumidamente, refere-se a uma dieta, um regime, mas que, no entanto, pode ir, e frequentemente vai, muito além do aspecto alimentar.

\footnotetext{
${ }^{28}$ Há, inclusive, uma discussão sobre a quantidade de animais mortos na produção de alimentos para suprir uma dieta vegetariana em comparação à uma dieta onívora, vide os artigos de Bertonatti (2016) e Chaves (2016) que debatem sobre o assunto. É preciso ressaltar que todo o debate em questão e a crítica vegetariana, evidentemente, gira em torno de animais de tamanho macroscópico e, especialmente, sencientes.
} 


\subsubsection{Origem e situação atual}

As evidências mais aceitas da origem do vegetarianismo remontam à tradição indiana (CARNEIRO, 2003), mais especificamente à civilização védica, que, de acordo com estudiosos, se desenvolveu no subcontinente indiano há, pelo menos, dois milênios A.E.C. (KOCHHAR, 2000). Até os dias atuais, em muitas linhas religiosas advindas da cultura védica, o vegetarianismo configura um importante preceito a ser observado, sendo diretamente relacionado com o princípio de hhimsa $^{29}$.

No entanto, a alimentação vegetariana ou semi-vegetariana na antiguidade não é uma exclusividade dos povos hindus. No Egito antigo, por exemplo, algumas evidências sugerem que certos grupos também sobreviviam com uma alimentação basicamente baseada em plantas (SPENCER, 1996; TOUZEAU et al., 2014).

Nas civilizações greco-romanas, é possível identificar a presença do vegetarianismo através dos escritos de Plutarco, Porfírio e Ovídio (BEARDSWORTH; KEIL, 1992; RUBY, 2012). No entanto, acredita-se que essa prática se disseminou no ocidente de maneira mais expressiva na antiguidade, com a doutrina pitagórica ${ }^{30}$.

Ao longo da história, diversos outros filósofos e autores em geral adotaram e defenderam o vegetarianismo ou, ainda, criticaram o consumo de carne sob diferentes óticas e pontos de vista, tais como: Alexander Pope, Agostinho da Silva, Albert Einstein, Alphonse de Lamartine, Amos Bronson Alcott, David Hartley, Élisée Reclus, Ellen White, Empédocles, Franz Kafka, Georg Friedrich Daumer, George Cheyne, George Bernard Shaw, Gustav Struve, Isaac Newton, John Ray, Johnny Appleseed, Joseph Ritson, Leonardo da Vinci, Lewis Gompertz, Liev Tolstoi, Mahavira, Mahatma Gandhi, Nikola Tesla, Nikolai Leskov, Percy Bysshe Shelley, Quinto Sextio, Rabindranath Tagore, Romain Rolland, Voltaire, William Alcott, dentre muitos outros (PHELPS, 2007; PREECE, 2003, 2009; WILLIAMS, 2003).

\footnotetext{
${ }^{29}$ Traduzido do sânscrito, o termo significa "não violência". Diz respeito a um princípio regulador observado em diversas religiões de origem hindu, tais como o brahmanismo, vishnuísmo, jainísmo e o budismo (WALTERS, 2012). Segundo as escrituras que citam o ahimsa, tais como o Mahabharata, o Iayurveda e os Upanixades, tratase da concepção de que todos os seres vivos, incluindo os animais, possuem uma centelha de energia espiritual divina e, portanto, não se deve causar ansiedade, sofrimento, morte ou qualquer outra forma de violência às outras entidades viventes.

${ }^{30} \mathrm{Um}$ dos primeiros difusores mais proeminentes do vegetarianismo no ocidente teria sido o filósofo e matemático grego Pitágoras. Sua doutrina defendia a ideia de não matar criaturas vivas, seja para o consumo alimentar ou para sacrifícios de outra natureza. Devido a sua influência e ao alcance de sua doutrina e ideias, antes do século XIX a dieta que atualmente nos referiríamos como sendo "vegetariana" era conhecida como "dieta pitagórica" (PHELPS, 2007).
} 
Obviamente, há uma grande assimetria entre os argumentos, visões, motivações, contextos e abordagem destas personalidades citadas. Seria equivocado colocar suas formas de pensar, tão distintas, ainda que se trate de um assunto similar, como a defesa de um mesmo senso vegetariano. Entretanto, são exemplos que ilustram a recorrente presença da noção de que a abstenção do consumo de carne na alimentação humana pode trazer benefícios de alguma natureza ou que tal concepção, ainda, é desejável sob algum ponto de vista.

Atualmente, em todo o mundo, por conta da cultura e religião, a Índia é o país com o maior percentual de vegetarianos, por volta de $40 \%$ da população (KEY; APPLEBY; ROSELL, 2006) e, em países da Europa ocidental o número varia entre $2 \%$ e $9 \%$ (AZEVEDO, 2013). Ainda que os critérios e definições nos levantamentos realizados variem ao redor do mundo, é possível apontar que, além da Índia, países como Alemanha, Austrália, Brasil, Israel, México, Nova Zelândia, Suécia e Taiwan estão entre os que possuem maiores percentuais de vegetarianos em suas populações, como mostra a Tabela 1.

Tabela 1 - Percentuais de vegetarianos em alguns países

\begin{tabular}{|c|c|c|}
\hline País & Percentual de vegetarianos & Referência bibliográfica \\
\hline Alemanha & $10 \%$ & $\begin{array}{l}\text { (O'RIORDAN; STOLL-KLEEMANN, } \\
2015)\end{array}$ \\
\hline Austrália & $11 \%$ & (MORGAN, 2016a) \\
\hline Brasil & $14 \%$ & $\begin{array}{l}\text { (INSTITUTO BRASILEIRO DE OPINIÃO } \\
\text { PÚBLICA E ESTATÍSTICA, 2018) }\end{array}$ \\
\hline Índia & $40 \%$ & (YADAV; KUMAR, 2006) \\
\hline Israel & $13 \%$ & (COHEN, 2015) \\
\hline México & $19 \%$ & (IGUALDAD ANIMAL, 2016) \\
\hline Nova Zelândia & $10.3 \%$ & (MORGAN, 2016b) \\
\hline Suécia & $10 \%$ & (THE LOCAL, 2014) \\
\hline Taiwan & $13 \%$ & (SAWE, 2017) \\
\hline
\end{tabular}

Fonte: Elaborado pelo autor.

O número de adeptos dessa prática no Brasil cresceu consideravelmente nos últimos 20 anos. Segundo o Instituto Brasileiro de Opinião Pública e Estatística (IBOPE), em 2012, $8 \%$ dos brasileiros afirmaram serem adeptos, de alguma forma de vegetarianismo, sendo que as cidades de São Paulo e do Rio de Janeiro possuíam, respectivamente, as maiores concentrações de pessoas de que adotaram essa dieta no país. Podemos ainda ressaltar que, segundo o mesmo estudo, $28 \%$ da população brasileira deseja reduzir, de alguma maneira, o 
consumo de carne (INSTITUTO BRASILEIRO DE OPINIÃO PÚBLICA E ESTATÍSTICA, 2012). Já no ano de 2018, em novo levantamento do IBOPE sobre o assunto, foi constatado que $14 \%$ da população brasileira se declarava vegetariana (INSTITUTO BRASILEIRO DE OPINIÃO PÚBLICA E ESTATÍSTICA, 2018).

Ainda que algumas contestações possam ser feitas em relação a estas pesquisas ${ }^{31}$, é nítido que não apenas os adeptos desse sistema alimentar estão crescendo, mas, o mercado de produtos e serviços focados neste nicho também está aumentando. Segundo a mesma pesquisa de 2018 do IBOPE, 60\% dos entrevistados consumiriam mais produtos veganos se estes tivessem os mesmos preços dos de origem animal (INSTITUTO BRASILEIRO DE OPINIÃO PÚBLICA E ESTATÍSTICA, 2018). No ano de 2018 existiam mais de 240 restaurantes vegetarianos no Brasil (SOCIEDADE VEGETARIANA BRASILEIRA, 2018b). No âmbito internacional, segundo pesquisa publicada pela revista Forbes, com dados da empresa de mídia digital GlobalData PLC, $70 \%$ da população mundial, em especial o público mais jovem, procura, de alguma forma, reduzir o consumo de carne. De acordo com o mesmo estudo, o veganismo nos Estados Unidos da América (EUA) aumentou 600\% entre os anos de 2015 e 2018 (ROWLAND, 2018).

Paralelamente, o interesse pelo assunto é crescente e reflete estas tendências mundiais. No Brasil, segundo o Google Trends, as buscas pelo termo "vegano" na internet aumentaram 14 vezes entre 2012 e 2017 (SOCIEDADE VEGETARIANA BRASILEIRA, 2018b). Há todo um interesse e um mercado em ascensão que atende não só o público estritamente vegetariano, mas muitas pessoas que procuram consumir menos carne por diversos motivos. As empresas especialistas em produtos alimentícios estão atentas a esse fenômeno. O mercado de proteínas vegetais, que era de aproximadamente 7,8 bilhões de dólares em 2013, poderá superar os 11 bilhões de dólares em 2018, segundo relatório da Nutrikéo, empresa francesa de estratégia e consultoria alimentar (NUTRIKÉO, 2015).

\footnotetext{
${ }^{31}$ Na pesquisa do IBOPE de 2018, os participantes foram considerados vegetarianos, ou não, de acordo com sua declaração à pergunta: "o quanto você concorda ou discorda: sou vegetariano". A soma dos que concordavam totalmente ou parcialmente com a afirmação configurou os $14 \%$ (PORTAL G1, 2018a). É possível que uma parcela destas pessoas poderia ser tecnicamente melhor enquadrada como semi-vegetariana.
} 


\subsubsection{Motivações e discussões que transcendem a dieta}

Alimentar-se de uma determinada maneira ao invés de outras, não é apenas uma questão de disponibilidade de alimentos, trata-se, muitas vezes, de uma questão cultural, religiosa e, até mesmo, ideológica ou política ${ }^{32}$. Com o vegetarianismo não é diferente, ele tem sido não apenas um sistema alimentar ou uma dieta, mas uma forma de ativismo alimentar $^{33}$, que envolve questões éticas, ambientais, sociais, nutricionais, científicas e culturais, na qual se defende não apenas a redução da produção e consumo de produtos de origem animal, mas, muitas vezes, sua total eliminação (AZEVEDO, 2013).

Observando sob a ótica do consumo individual, e levando em conta as definições descritas nos Quadros 1 e 2, é possível estabelecer que o conceito de vegetarianismo invocaria uma perspectiva mais próxima, mas não necessariamente homóloga, de uma de abstenção de consumo, ou seja, uma ação de boicote ${ }^{34}$. Já as diferentes formas de semi-vegetarianismo estariam mais próximas de uma perspectiva de redução de consumo. Para Singer:

O vegetarianismo é uma forma de boicote. Para a maioria dos vegetarianos, o boicote é definitivo visto que, uma vez tendo quebrado os hábitos de ingestão de animais, não conseguem aprovar a morte de animais por forma a satisfazer os desejos triviais dos seus palatos (SINGER, 2004, pp. 127).

Por mais que sua definição e prática esteja relacionada direta e objetivamente com a alimentação, o vegetarianismo, muitas vezes, transcende a ideia de regime, dieta ou escolha individual (AZEVEDO, 2013; GREIF, 2002; RUBY, 2012), podendo ser enquadrado como uma forma de ideologia alimentar ${ }^{35}$ e politização do consumo (PORTILHO; CASTAÑEDA, 2008).

Para melhor compreender a gama de questões e dimensões que podem estar envolvidas nesse tema, é preciso entender as motivações por trás da adoção do

\footnotetext{
${ }^{32}$ Especialmente se considerarmos o aspecto alimentar implícito no veganismo que, como foi discutido no 1.1 , assume contornos éticos e político-ideológicos (SORDI, 2013). Entretanto, é preciso ressaltar que consumo de carne não é diferente, pois também se apoia em questões políticas e ideológicas, como mostrará a seção 2.1 deste trabalho.

${ }^{33}$ Para mais detalhes sobre ativismo alimentar, vide Azevedo (2017).

${ }^{34}$ Prática política que diz respeito à abstenção do consumo de determinados serviços e produtos devido a questões sociais ou ambientais (PORTILHO; CASTAÑEDA; CASTRO, 2011).

${ }^{35}$ Para mais detalhes sobre a alimentação no contexto político contemporâneo, vide Portilho e Castaneda (2011). Sobre a discussão dos aspectos ideológicos do vegetarianismo, vide Lawrence (1993) e Azevedo (2013).
} 
vegetarianismo. Segundo os estudos que procuram compreender esse fator, há um gama de argumentos, ideias e justificativas, as quais se apresentam de forma consideravelmente diversificada e abordam diversos aspectos, tais como saúde, nutrição, meio ambiente, ética, direitos dos animais, questões religiosas, dentre outras (AZEVEDO, 2013; HOFFMAN et al., 2013; RUBY, 2012).

Existem trabalhos que propõem classificações e agrupamentos das motivações mais recorrentes para as práticas vegetarianas. Segundo Fox e Ward (2008), tratam-se de três eixos temáticos principais: ética, saúde e meio ambiente. Rothgerber (2014) agrupa em dois eixos principais: saúde e ética, uma vez que, para o autor, as preocupações ambientais estariam dentro da ética. Beardsworth e Keil (1992) utilizam as classificações: moral, saúde, paladar e ambiental. Já Ruby (2012), propõe como categorias: ética, saúde, meio ambiente, religião e até mesmo nojo.

Se considerarmos a complexidade e diversidade das motivações em questão, é possível perceber que elas se apresentam, frequentemente, de forma interligada e, muitas vezes, fundamentam, somam e reforçam umas às outras, podendo, inclusive, confundir-se entre si. Por exemplo, motivações relacionadas com a dimensão socioambiental do vegetarianismo, as quais são o foco dessa pesquisa, poderiam ser tratadas como questões de saúde, se consideramos o campo de saúde ambiental e a nítida conexão existente entre o ambiente e o bem-estar físico e mental do ser humano ${ }^{36}$.

Também seria possível inserir a problemática ambiental levantada nas motivações vegetarianas dentro da categoria de problema de caráter ético ${ }^{37}$. Esta conexão é explorada pelo trabalho de Maturana (2015), no qual o autor declara:

(...) ao se analisar a forma de produção de alimentos na atualidade, percebe-se que há questões éticas a serem analisadas, em especial quando a produção industrial interfere e afeta diretamente a vida de milhares de outras espécies de animais e vegetais e que afeta todo um ecossistema e equilíbrio planetário (MATURANA, 2015, p. 67).

Sejam quais forem as categorias utilizadas para enquadrar as motivações que levam à adoção de um sistema alimentar vegetariano, é possível reconhecer que, primeiramente, há

\footnotetext{
${ }^{36}$ Para mais detalhes sobre saúde ambiental ver Teixeira (2012).

${ }^{37}$ Não que o vegetarianismo seja enquadrado como, necessariamente, uma prática "ética" e o consumo de carne como uma prática "não ética", mas é importante salientar que a discussão sobre o tema envolve assuntos compreendidos dentro do campo da ética.
} 
uma diversidade na natureza e na forma com que essas justificativas e argumentos adotados se apresentam, bem como os temas que elas evolvem (FOX; WARD, 2008; JANSSEN et al., 2016; NUNES, 2010; ROSENFELD; BURROW, 2017; RUBY, 2012). Além disso, segundo algumas pesquisas (ABONIZIO, 2016; FOX; WARD, 2008; ROSENFELD; BURROW, 2017; RUBY, 2012) é possível reconhecer que, de modo geral, tanto no Brasil como em diversos outros países, as motivações consideradas primárias e mais recorrentes costumam estar relacionadas à aspectos éticos ${ }^{38}$ ou relacionadas à saúde ${ }^{39}$. Os motivos relacionados a questões como meio ambiente, ecologia, sustentabilidade e outros temas similares, costumam aparecer de maneira secundária ou complementativa na maior parte das vezes.

Diversas outras dimensões e questões apresentam paralelos e, muitas vezes, se mesclam com as motivações do vegetarianismo. Mesmo se tratando de veganismo e não de vegetarianismo apenas, podemos citar, por exemplo, a teoria feminista-vegana, apresentada por Carol Adams no livro "A política sexual da carne", onde a autora expõe uma forte conexão entre o feminismo e o veganismo, traçando paralelos entre aspectos da exploração animal e o machismo ${ }^{40}$ (ADAMS, 2015).

É possível, ainda, ressaltar as relações do vegetarianismo com certos outros movimentos sociais, o que fomentaria a ideia de que há uma conexão entre diversas formas de opressão, conforme explorado no artigo de Weissheimer (2018). Há, ainda, estudos como o de Caviola, Everett e Faber (2018), que atestam que o especismo possui uma correlação psicológica com outras formas de preconceito, como homofobia, sexismo e racismo.

Diferentes ideologias alimentares que são consideradas alternativas aos processos convencionais de produção, tais como a opção por alimentos orgânicos, tem adquirido, tal qual o vegetarianismo, cada vez mais visibilidade política (PORTILHO; CASTAÑEDA, 2008).

Ainda que não seja o foco deste trabalho esmiuçar os detalhes e relações existentes entre diversos movimentos alternativos aos processos convencionais de consumo de

\footnotetext{
${ }^{38} \mathrm{Ou}$ "morais", como é utilizado em alguns trabalhos (ABONIZIO, 2016; RUBY, 2012). Como maior parte dos trabalhos acadêmicos revisados utilizam o termo "ética", iremos utilizar este para definir o conjunto de motivações.

${ }^{39} \mathrm{Ou}$, como alguns autores preferem, aspectos "nutricionais".

${ }^{40}$ Dentro deste tema há, inclusive, uma controvérsia sobre a relação entre o vegetarianismo e o feminismo, como mostrado no trabalho de Azevedo (2013), que apresenta o contraponto entre a visão feminista vegana de Carol Adams (2015) e a crítica feminista ao vegetarianismo ético feita por Kathryn Paxton George (2000).
} 
$\operatorname{alimentos}^{41}$, é preciso situar o vegetarianismo paralelo a outras formas de ativismo alimentar, tais como a agroecologia e agricultura familiar, o slow food, o movimento de segurança alimentar, o freeganismo, o locavorismo, o comércio justo e, como já citado, a própria agricultura orgânica (AZEVEDO, 2017). Inclusive, tratando-se da resistência ao modelo industrial de produção de carne, especificamente, é preciso ressaltar que não são apenas os grupos vegetarianos e animalistas que apresentam-se como alternativa nesse cenário. Os próprios movimentos de slow food e de locavorismo podem comportar formas de carnivorismo alternativas em suas agendas (WEISS, 2012). De acordo com Sordi (2013, p. 137), talvez mais ameaçador para a cadeia da carne que o vegetarianismo militante, seja o discurso nutricional contemporâneo que prega moderação no consumo de carne, e não exatamente sua abolição.

Enquanto tais alternativas se aproximam da moderação e da redução, tal como a flexibilidade da ideia de dietas baseadas em plantas, o vegetarianismo invoca uma perspectiva mais próxima da abstenção e, por conta disso, é muitas vezes tida como mais radical. Um risco que isso pode trazer, especialmente tendo em vista os obstáculos, discriminações e estigmatizações que os vegetarianos e veganos já enfrentam ${ }^{42}$, é da escolha entre o vegetarianismo e o consumo de carne ser apresentada próxima ao que Pignarre e Stengers (2011) chamam de "alternativa infernal". Seja por parte dos defensores da indústria pecuária, que colocam os modos de consumo e produção de carne atuais como a única escolha em contraponto à abstenção total de carne na dieta e suas possíveis consequências negativas ${ }^{43}$, seja por parte de ativistas que consideram o veganismo como sendo "a única base moral coerente e que não existe posição intermediária moralmente justificável nessa jornada em defesa dos animais" ${ }^{\prime 4}$.

É preciso reconhecer que o veganismo, ou ainda o vegetarianismo estrito, talvez estejam entre as formas de consumo político mais significativos no que diz respeito a trazer à tona discussões sobre os direitos dos animais. No entanto, a defesa de um "fundamentalismo vegetariano", ou de uma visão "purista” do veganismo, que descarta automaticamente todas

\footnotetext{
${ }^{41}$ Ou como Azevedo (2017) define: "comer de outras formas".

42 Alguns exemplos, tais como o estereótipo do vegetariano doente ou a visão da carne como símbolo de masculinidade e virilidade, podem ser encontrados nos trabalhos de Nunes (2010) e Sordi (2013).

${ }^{43}$ É possível ver exemplos dessa abordagem na reportagem publicada pelo Beef Point, onde são apresentados relatos pontuais e pessoais de consequências negativas do vegetarianismo (BEEF POINT, 2017b).

44 Trecho do vídeo "Vegetarianismo não faz sentido" (ARGUMENTOS VEGANOS, 2017) .
} 
as outras abordagens que moderam o consumo de carne e a relação com os animais, bem como as "alternativas infernais" que essa situação gera, traz um risco de uma maior polarização na discussão, bem como pode afastar pessoas de movimentos que desaceleram o consumo e, até mesmo, das próprias ideias vegetarianas. De acordo com Marras (2014):

Por mais respeitáveis que sejam esses movimentos e seus adeptos, considero suas soluções ainda inscritas no pensamento dos lados - e não do aberto -, ainda uma recusa do trânsito ontológico, e com o grave risco de tornar-se algo dogmático, sentencioso (MARRAS, 2014, p. 252).

Por outro lado, por mais que categorias mais flexíveis, como as DBP, possam ser consideradas mais aceitáveis socialmente, a defesa de um certo vegetarianismo ético e estrito, em seu aspecto considerado mais "radical", possui como aliados argumentos bem marcantes e incisivos. Tais argumentos, como, por exemplo, a ideia de abolicionismo animal ${ }^{45}$, acabam por ter também um forte apelo para a aceitação do vegetarianismo e veganismo em muitos casos (BRÜGGER, 2009; FRANCIONE, 2008). Por fim, é possível tanto identificar os riscos de abordagens mais radicais, quanto seu apelo mais assertivo para alguns.

Antes de adentrar as questões socioambientais que tocam o tema, foco desta pesquisa, é necessário compreender panoramicamente algumas das principais ideias envolvidas nestas motivações primárias para vegetarianos: ética e saúde.

\subsubsection{Vegetarianismo e ética animal}

Uma das categorias de motivações para adoção de dietas vegetarianas envolvem aspectos que poderíamos caracterizar como relacionados à ética, de alguma forma (FOX; WARD, 2008; MULLEE et al., 2017; RUBY, 2012). Sob tal ótica, há uma ampla gama de questões envolvidas quando se observa tanto a produção industrial e o consumo massivo de carne, quanto as próprias relações entre humanos e animais na nossa sociedade ocidental moderna. Cada um destes tópicos gera diversas discussões e controvérsias, dentro e fora do âmbito acadêmico, e são objetos de numerosos estudos.

\footnotetext{
${ }^{45} \mathrm{O}$ abolicionismo animal, melhor definido no item 2.1.3, é, por vezes, colocado, por ativistas veganos, em paralelo ao abolicionismo da escravidão humana, o que gera algumas discussões e polêmicas. Tal situação é descrita no trabalho de Nunes (2010).
} 
Sem a pretensão de desdobrar todos os temas, o intuito deste item é trazer à tona algumas das principais questões de natureza ética, frequentemente presentes na discussão. Ainda que tais questões não sejam diretamente relevantes para as problemáticas socioambientais que serão abordadas, elas são estruturais para compreender os contornos do vegetarianismo, tendo em vista sua proeminência nas motivações dos adeptos e sua importância no debate como um todo ${ }^{46}$.

"Direitos dos animais" talvez seja um dos tópicos mais frequentes quando se debate o não-consumo de carne. A visão antiantropocentrista de Singer (2004) expressa bem a ideia de retirar os animais da posição de objeto, os considerando não como propriedades ou como simples meios para fins humanos, mas como sujeitos, inclusos em nossa comunidade moral. É preciso citar, ainda, a existência da Declaração Universal para o Direito dos Animais, proclamada pela UNESCO, em 27 de janeiro de 1978, que visa criar parâmetros para outros países no assunto em questão (ORGANIZAÇÃO DAS NAÇÕES UNIDAS PARA A EDUCAÇÃO A CIÊNCIA E A CULTURA, [s.d.]).

No entanto, para compreender melhor o que distingue a visão de direito dos animais de boa parte dos vegetarianos e veganos, especialmente, é preciso compreender os conceitos de "abolicionismo" e "bem estarismo" animal.

A ideia de abolicionismo animal, estrutural para o veganismo e frequente nas motivações vegetarianas de caratér ético, advoga a abolição de todas as formas de exploração animal, seja para a produção de carne ou para outros fins. Ela se baseia na constatação dos animais como seres senscientes ${ }^{47}$ e considera o veganismo uma espécie de base moral para sua prática (BRÜGGER, 2009; FRANCIONE, 2008). Essa ideia costuma se contrapor ao chamado "bem estarismo animal" ${ }^{48}$, perspectiva que defende que, garantidas boas condições de vida e bem estar ao animal, é legítima a sua criação e abate (BRÜGGER, 2009).

Segundo relatório da Heinrich Boll Foundation (2015),

Os movimentos em defesa do bem-estar dos animais apontam frequentes violações de regulação e crueldade, tais como viagens longas, anestesia inadequada ou sofrimento desmedido quando são golpeados para serem levados aos matadouros. Já os movimentos dos direitos dos animais, por sua vez, criticam o assassinato em série

\footnotetext{
${ }^{46}$ Como demonstrado por Abonízio (2016).

${ }^{47} \mathrm{O}$ conceito de senciência refere-se à capacidade dos seres vivos de experimentarem sensações tais como dor, prazer ou felicidade (SINGER, 2004).

${ }^{48}$ Trata-se de um neologismo que vem de sua versão em inglês: “welfarist”. Adeptos dessa linha de pensamento também são referidos como "reformistas" (BRÜGGER, 2009).
} 
de animais como uma questão de princípios: afirmam que a produção de carne está associada à violência contra os animais. Os ativistas dessa corrente não querem reformar o abate, querem erradicá-lo completamente. Afirmam que a indústria da carne considera os animais como meros produtos, enquanto a sociedade deveria reconhecer sua individualidade e capacidade de sofrer (HEINRICH BÖLL FOUNDATION, 2015, p. 27).

Por parte dos abolicionistas, o termo "holocausto animal" e paralelos com a escravidão humana são frequentemente utilizados para se referir à indústria do abate (GOMES, 2006; NUNES, 2010), o que demonstra a seriedade com que essa situação é tomada dentro desta linha de pensamento.

De modo mais geral, existe todo um movimento crescente de "globalização do bem estar animal" (PARK; SINGER, 2012), o que gera pressão e exigências por parte dos consumidores finais de carne e de países que importam carne. Com isso, surgiram normas, acordos e certificações ${ }^{49}$ tendo em vista a questão do direito dos animais, tanto internacionalmente quanto no Brasil (SORDI, 2013).

Levando em conta a dependência da nossa sociedade para com os animais (o que não é algo atual, mas fruto de uma coevolução), é preciso trazer à tona a perspectiva de que o maior problema não estaria no ato matar estes seres, mas na banalização destas mortes, ou, como ressaltado no trabalho de Marras (2014) e segundo as palavras de Haraway (2011), no "tornar matável". "Não é matar que nos leva ao exterminismo, mas sim tornar os animais matáveis" (HARAWAY, 2011, p. 43). É necessário ressaltar que isso está diretamente relacionado com a conversão do animal em mercadoria em nossos sistemas produtivos.

Toda essa questão do direito dos animais, seja pela abordagem abolicionista, seja pela abordagem bem-estarista, acaba por invocar discussões mais profundas, que remetem a natureza da própria relação humano-animal. Produção pecuária industrial, vivisecção, domesticação: grande parte das dinâmicas que estabelecemos com os animais, em nosso contexto de sociedade ocidental moderna, é caracterizada por relações de poder bem claras.

Para que tais relações se configurem desta forma, existem certos conceitos, perspectivas e pensamentos utilizados para seu embasamento e justificativa. A dicotomia criada entre o animal e o humano é uma destas. De acordo com Ingold (1995), o conceito de animal, arraigado em nossa civilização ocidental atual, carrega consigo uma série de características, ambiguidades, preconceitos e informações. Este conceito possui um

\footnotetext{
49 Tais como a norma de responsabilidade social ISO 26000, que inclui o bem estar dos animais em suas diretrizes (ASSOCIAÇÃO BRASILEIRA DE NORMAS TÉCNICAS, 2010).
} 
importante papel na própria definição do que acaba por ser considerado humano. Em nosso mundo ocidental as palavras "homem" e "animal" podem ser apresentadas com um sentido dicotômico, apresentando duas zonas ontológicas distintas: a animalidade e a humanidade.

O próprio conceito não traz consigo apenas a concepção do somatório de membros da categoria biológica Homo-sapiens, mas anuncia frequentemente uma oposição, uma condição humana única, que é contrária à condição animal. Eis, portanto, a separação entre o ser humano como espécie, ou seja, o animal-humano, e o ser humano como condição, ou como nos é familiar escutar, como pessoa (INGOLD, 1995). Tais separações não só influenciam, mas, embasam a maneira com que lidamos e atuamos para com as outras espécies de animais não-humanos ou até mesmo no que consideramos a vida como um todo (INGOLD, 2011). Nesse contexto, a dicotomia humano-animal, paralela à separação moderna entre os domínios ontológicos de sociedade e natureza e de sujeito e objeto, citados por Latour (2009), gera uma alteridade que facilita uma visão dessubjetificada dos animais. De acordo com Sordi (2013):

\begin{abstract}
(...) o consumo de animais e seus produtos por grupos humanos sempre demandou algum tipo de procedimento técnico-ritual de dessubjetivação dos mesmos, capaz de reificá-los para melhor consumi-los. Cada cultura possui seus próprios meios de proceder esta alquimia simbólica, isto é, seus próprios meios de reificação e dessubjetivação. Nossa sociedade industrial também possui os seus, como bem ilustram os procedimentos de "manejo racional" destinados a administrar a subjetividade animal na produção de carne (SORDI, 2013, p. 122).
\end{abstract}

Para alguns, as perspectivas mecanicistas e antropocêntricas são fundamentais na maneira predatória com que nos relacionamos com a natureza e, portanto, são grande parte da causa dos problemas ambientais que enfrentamos. Nesse âmbito, as manifestações consideradas como especistas, estabelecidas dentro da relação humanos-animais, criticadas por vegetarianos e veganos, seriam uma expressão e consequência do antropocentrismo, intrínseco às formas hegemônicas de conceber a relação sociedade-natureza (BRÜGGER, 2009).

Ainda que toda essa situação gere acusações, por parte de muitos vegetarianos, de crueldade e insensibilidade (ABONIZIO, 2016), outros criticam os traços utópicos do vegetarianismo (SORDI, 2013). Segundo Pondé (2009):

Não há dúvida de que há algo de monstruoso na humanidade, mas o que me espanta nesses "conscientes" é a cegueira para o fato de que a natureza não seja um mar dócil, mas sim um espaço de violência. A humanidade tem algo de monstruoso 
porque ela é parte da natureza. Se dependêssemos desses "conscientes", não teríamos sobrevivido à seleção natural. Teríamos caído paralisados diante da necessidade de matar para sobreviver, por um lado, e pelo outro lado, da dor de consciência por aniquilar a esperança de pequenos antílopes que corriam livres e saltitantes pela savana africana (PONDÉ, 2009).

Ainda dentro deste embate ético entre as ideologias alimentares opostas do vegetarianismo e do carnismo ${ }^{50}$, o número de animais mortos é um assunto em debate. Um artigo de 2015 do naturalista argentino Claudio Bertonatti, com grande repercussão na mídia, apontou que o pensamento de que a dieta vegetariana causa menos mortes e sofrimento animal seria falsa, uma vez que a agricultura é a grande causa de mortes de animais (BERTONATTI, 2016). Ainda que levemos em conta a observação óbvia de que é praticamente impossível manter a produção de alimentos atual sem causar algum dano, é preciso ressaltar que grande parte da agricultura é utilizada para alimentar animais de corte e que, a indústria de produção animal é o fator de maior impacto sobre o desmatamento, perda de habitats e consequente perda da biodiversidade em diversos locais (FOOD AND AGRICULTURE ORGANIZATION OF THE UNITED NATIONS, 2006; FOX, 2000; MACHOVINA; FEELEY; RIPPLE, 2015; NETHERLANDS ENVIRONMENTAL ASSESSMENT AGENCY, 2010). Por fim, ambas as dietas, com ou sem carne, acabam causando algum sofrimento e mortes de animais. Entretanto, há de se levar em conta que, de modo geral, os impactos de dietas vegetarianas são reduzidos nesse aspecto, ainda que não nulos.

As perspectivas opostas, abordadas nos parágrafos anteriores, proveem um panorama da amplitude da discussão e das questões de diversas naturezas que emergem com o vegetarianismo e seu debate ético. No entanto, é preciso ressaltar que existem diversos outros argumentos, discussões e pontos de vista quando tratamos do abate de animais e do consumo de carne, não se resumindo, apenas, a definir como "certo" ou "errado" as diferentes práticas, de uma forma dicotômica.

\footnotetext{
${ }^{50}$ Sistema de crenças e ideologia que justifica a morte de certos animais para o consumo humano. O termo, popularizado especialmente pela psicóloga social Melanie Joy (2010), é uma definição recorrente aos que defendem o consumo de carne e, muitas vezes, é até utilizado como categoria de acusação por parte de defensores dos direitos dos animais.
} 


\subsubsection{Saúde e nutrição}

No que diz respeito à saúde e nutrição, diferentes formas de vegetarianismo são frequentemente associadas à uma maneira mais saudável de se alimentar (NUNES, 2010; ROSENFELD; BURROW, 2017; RUBY, 2012), ainda que isso, muitas vezes, gere controvérsias (SORDI, 2013). Ao mesmo tempo em que o consumo de certos tipos de carne ${ }^{51}$ esteja relacionado com problemas de saúde diversos (LARSSON; ORSINI, 2013), por outro lado, a carne é considerada como um alimento essencial e de alta densidade nutricional, especialmente no que diz respeito a proteínas, ácidos graxos, vitaminas do complexo B e alguns minerais (MEDEIROS, 2008).

Diversos problemas na saúde humana são relacionados diretamente às altas taxas de ingestão de certos produtos de origem animal (BOUVARD et al., 2015; LARSSON; ORSINI, 2013). Alguns estudos apontam uma redução significativa de alimentos de origem animal como uma das principais recomendações para melhorias na saúde da população ${ }^{52}$ (LOCK et al., 2010; SPRINGMANN et al., 2016). As justificativas do vegetarianismo, nesse sentido, geralmente se embasam nos benefícios que as DBP podem proporcionar, como demonstrado por Sringmann (2016).

A carne vermelha processada está relacionada significativamente, de maneira estatística, com maiores taxas de mortalidade (LARSSON; ORSINI, 2013). Por outro lado, alguns estudos (HUNT, 2003; KEY; APPLEBY; ROSELL, 2006) indicam que dietas vegetarianas estritas podem ser insuficientes em vitamina B12 sendo, inclusive, sua suplementação sintética é necessária, de acordo com parecer emitido pelo Conselho Reginal de Nutrição da $3^{\text {a }}$ região do Brasil (CONSELHO REGIONAL DE NUTRICIONISTAS, 2015).

Há, ainda, diversos assuntos que são debatidos e estudados, tais como a preocupação com os níveis de proteínas, ferro e zinco, especialmente em vegetarianos estritos. Existem muitos estudos sobre esses temas, que comparam, sob o ponto de vista nutricional, dietas vegetarianas e onívoras. Segundo Azevedo:

\footnotetext{
${ }^{51}$ Em especial carnes vermelhas processadas.

${ }^{52}$ É preciso ressaltar que os estudos que abordam malefícios e benefícios do não consumo de carne não dizem respeito à outras formas de consumir animais que estão fora da lógica de produção industrial e consumo em massa da sociedade moderna.
} 
Resumindo, o conceito de alimentação sem carne (e saudável) pode ser bastante plural, dependendo do país, do grupo de comensais e da qualidade e origem dos alimentos inclusos na dieta. Por isso, os atores de pesquisas e os dados devem ser levantados e avaliados com rigor, priorizando-se a coerência no perfil dos grupos comparados (AZEVEDO, 2013, p. 280).

As recomendações e as declarações dos estudos científicos variam de acordo com o tipo de dieta vegetariana em questão, além do aspecto que é focado. Resumidamente, é uma ampla gama de pontos para simplesmente definir uma categoria tão plural, como o caso do vegetarianismo, como sendo uma alimentação mais saudável ou não.

É preciso ressaltar que também existe uma discussão sobre a importância do consumo de carne e do ato de caçar no próprio processo evolutivo humano. Segundo os estudos mais recentes, estes dois aspectos foram fundamentais tanto para a evolução do nosso cérebro ${ }^{53}$ quanto para o aparecimento de outras características comportamentais importantes para a nossa espécie (LEROY; PRAET, 2015). De acordo com esse ponto de vista, comer carne seria não apenas um hábito, mas uma atividade biocultural, essencial para o ser humano.

Sem adentrar no debate sobre as importâncias simbólicas do tamanho do cérebro, apesar das evidências históricas de coevolução, Leroy e Praet (2015) afirmam:

Como um recurso precioso de energia e proteína, a carne tem sido relacionada ao desenvolvimento evolutivo dos hominídeos em mamíferos inteligentes e sociais, embora a cadeia de causalidade desse processo permanece incerto (LEROY; PRAET, 2015, p. 202, tradução nossa).

Nessa linha de pensamento, os benefícios para o cérebro, dada a sua alta demanda calórica, ocorreram devido a quantidade de proteína e, principalmente, gordura concentradas na carne. Ou seja, a carne cumpriu seu papel mais como um insumo nutricional e não como um gatilho de desenvolvimento (GAZZANIGA, 2012). Os desafios e necessidades para garantir a segurança alimentar e resolver problemas ${ }^{54}$ é que seriam os verdadeiros responsáveis pelo desenvolvimento de um cérebro maior (LEROY; PRAET, 2015).

\footnotetext{
${ }^{53}$ Existem, inclusive, indícios que mostram que o tamanho médio do cérebro humano diminuiu efetivamente desde a "era dos caçadores e coletores". Entretanto, tal fenômeno, especificamente, não está correlacionado diretamente a alguma mudança no consumo de alimentos de origem animal, mas na diminuição da necessidade do uso de certas habilidades mentais para sobrevivência, as quais passaram a não ser necessárias com as sociedades agrícolas (HARARI, 2017).

${ }^{54} \mathrm{Na}$ qual a caça se inclui, especialmente por sua necessidade de comunicação, organização e planejamento entre indivíduos, mas também é possível citar outros fatores, como a necessidade de desenvolvimento de ferramentas e da linguagem, bem como o domínio do fogo (KAPLAN et al., 2000).
} 
O ponto defendido pelos vegetarianos é que podemos suprir o cérebro, e o corpo de forma geral, com gorduras e proteínas de origem vegetal, as quais produzimos em abundância atualmente, e que, se consumidas corretamente, vão funcionar da mesma maneira que as de origem animal (SORDI, 2013). Logo, no vegetarianismo não há nenhum risco de atrofia cerebral, ou sequer de níveis mais baixos de inteligência ${ }^{55}$, como, por exemplo, é demonstrado por um estudo de coorte de Gale et al. (2007).

Tratando-se ainda do argumento que defende uma dependência evolutiva do ser humano para com o consumo de carne, segundo alguns autores (EVANS-PRITCHARD, 2008; INGOLD, 1988; WILKIE, 2010), apesar das evidências da forte presença da caça na trajetória humana, o consumo de carne como principal motivo da criação acontece tardiamente na história da própria domesticação animal, uma vez registros etnográficos sugerem que as funções principais de diversas espécies costumava ser, primeiramente, a sua força de trabalho e transporte, seus subprodutos e como valor de troca. Nestes casos o consumo de carne surgia quando os animais sofriam mortes acidentais ou em casos de sacrifícios (SORDI, 2013).

Deixando de lado o aspecto evolutivo e nutricional individual, existem também outros tópicos relevantes com relação à saúde pública. Em países "em desenvolvimento", treze tipos de zoonoses, originárias de bois, galinhas e porcos, estão associadas com mais de dois milhões de mortes e 2,4 bilhões de casos de infecção humana anualmente (INTERNATIONAL LIVESTOCK RESEARCH INSTITUTE, 2012). Há também o problema de contaminação das águas, uma vez que o setor pecuário é, provavelmente, a maior fonte setorial de poluição de corpos hídricos no planeta (FOOD AND AGRICULTURE ORGANIZATION OF THE UNITED NATIONS, 2006).

A resistência humana à certos medicamentos e a proliferação de bactérias resistentes ${ }^{56}$ também estão associadas diretamente à pecuária, por conta do uso excessivo (muitas vezes, mal administrado) de antibióticos por esse setor (REARDON, 2014), seja para prevenção de doenças, seja para a aceleração do processo de crescimento dos animais (HEINRICH BÖLL

\footnotetext{
55 A ideia do consumo de carne como um sinônimo de superioridade intelectual, inclusive, já fomentou teses racistas, como o caso implícito no trabalho de Wherry (1913), que defendeu que um dos fatores que permitiu o domínio colonial do Império Britânico sobre a Índia foi o alto consumo de proteínas animais pelos ingleses, em contraste com a dieta vegetariana o povo hindu (AZEVEDO, 2013).

56 Também chamadas de "superbactérias", que podem ser transmitidas dos animais para os seres humanos de diversas formas (HEINRICH BÖLL FOUNDATION, 2015).
} 
FOUNDATION, 2015). Diversos estudos ${ }^{57}$ abordam tal questão e trazem à tona os riscos envolvidos na saúde pública e ambiental.

No que diz respeito às variações do "saudável", dentro do próprio espectro de diferentes carnes que compõem a dieta humana, é preciso ressaltar que há graduações nas carnes consideradas mais ou menos saudáveis, dependendo do aspecto nutricional levado em conta. Se levarmos em conta o teor de gordura por exemplo, carnes de aves costumam ser consideradas mais saudáveis do que carnes suínas e bovinas (MARÇAL et al., 2016). A mesma variação ocorre em função do grau de processamento e do modo de produção envolvido: a carne vermelha processada está associada a um maior risco de mortalidade que a não processada (LARSSON; ORSINI, 2013) e alimentos oriundos de animais criados em sistemas intensivos são, geralmente, considerados menos saudáveis que aqueles que provêm de sistemas extensivos $^{58}$ (EMPRESA BRASILEIRA DE PESQUISA AGROPECUÁRIA, 2018a; HEINRICH BÖLL FOUNDATION, 2015).

A soma de questões nutricionais individuais, problemas de zoonoses, contaminações, bactérias resistentes, além dos problemas ambientais ${ }^{59}$ da produção e consumo de carne, configura um cenário de forte impacto, ainda não tão bem dimensionado, sobre a saúde da população como um todo (HEINRICH BÖLL FOUNDATION, 2015). Tudo isso faz com que haja um extenso e controverso debate sobre a relação entre dietas vegetarianas e saúde. Como o objetivo do trabalho não é focar esse aspecto, uma vez já que reconhecemos a existência, pluralidade e natureza dessa discussão, é preciso estabelecer algumas premissas relacionadas à saúde e nutrição, fundamentais para o desenvolvimento do restante da pesquisa ${ }^{60}$ :

- Dietas vegetarianas, quando bem planejadas, promovem normalmente o crescimento, desenvolvimento e manutenção adequado do ser humano, podendo ser adotadas em qualquer ciclo de vida (CONSELHO REGIONAL DE NUTRICIONISTAS, 2015; MELINA; CRAIG; LEVIN, 2016).

\footnotetext{
${ }^{57}$ Tais como os de Hayes et al. (2004) Sapkota et al. (2011) e Jackson et al. (2004).

${ }^{58}$ A carne bovina brasileira, predominantemente produzida em sistemas de corte extensivos, é frequentemente considerada como sendo de alta qualidade, seja pelo uso muito baixo ou nulo de antibióticos nesses sistemas (BEEF POINT, 2001; SORDI, 2013) ou pela alimentação do boi com plantas forrageiras, considerada como mais natural (AMARAL et al., 2012).

${ }^{59}$ Esses problemas ambientais serão melhor desenvolvidos ao longo desta dissertação.

${ }^{60}$ Longe de estabelecer tais premissas como verdades absolutas ou de suprimir as controvérsias e debates por detrás do assunto, a discussão do vegetarianismo e suas possibilidades de caráter socioambiental, foco dessa pesquisa, só se faz possível se partirmos do princípio de que se trata de um regime alimentar seguro, e, portanto, possível, para o ser humano sob o ponto de vista médico e nutricional.
} 
- O consumo de carnes ou de outros alimentos de origem animal não é absolutamente imprescindível para uma alimentação saudável (MELINA; CRAIG; LEVIN, 2016; MINISTÉRIO DA SAÚDE, 2014).

- Qualquer dieta mal planejada, seja ela onívora ou vegetariana possui o potencial de ser prejudicial à saúde, levando à deficiências nutricionais (CONSELHO REGIONAL DE NUTRICIONISTAS, 2015).

- O Homo sapiens é considerado como uma espécie onívora, ou seja, pode se nutrir tanto de alimentos de origem vegetal quanto de origem animal (HARARI, 2017; MAZOYER; ROUDART, 2010). Em conclusão, a constituição biológica do ser humano não exclui a possibilidade de se adotar dietas vegetarianas (CONSELHO REGIONAL DE NUTRICIONISTAS, 2015).

- Na maior parte dos casos, reduzir o consumo de carne não representa um conflito entre saúde e meio ambiente (MACDIARMID, 2013).

\subsection{Entrando na dimensão ambiental}

Apesar de geralmente não aparecer como um motivador primário, uma das justificativas mais frequentes para a adoção de dietas vegetarianas diz respeito ao aspecto ambiental (FOX; WARD, 2008; MORTARA, 2013; ROSENFELD; BURROW, 2017; RUBY, 2012). Preocupações de caráter socioambiental e as noções de sustentabilidade ${ }^{61}$ estão, cada vez mais, sendo associadas ao vegetarianismo, como mostram diversos estudos (AZEVEDO, 2013; CAPUTO et al., 2012; FOX, 2000; GAARD, 2002; GREIF, 2002; LINDEMAN; SIRELIUS, 2001; LOPES, 2013; MORTARA, 2013; SALONEN; HELNE, 2012; SORDI, 2013; WALTERS, 2012).

Antes de apresentar tais informações que desvelam a dimensão socioambiental do tema e ajudam a traçar o contorno de um vegetarianismo ambiental, é possível observar, através de uma revisão histórica de determinadas ideias e constatações empíricas que vão de encontro à discussão.

\footnotetext{
${ }^{61}$ Ainda que a ideia de sustentabilidade possa envolver outras questões, além da estritamente ambiental. Para mais detalhes sobre a diversidade de dimensões e tópicos relacionados a conceito, ver Sachs (1993), Jacobi (1996) e Veiga (VEIGA, 2010, 2014).
} 


\subsubsection{Conexões parciais do vegetarianismo ambiental na história humana}

A recomendação de uma dieta que se baseie em alimentos de origem vegetal, ao invés daqueles de origem animal ${ }^{62}$, visando critérios que, atualmente, poderíamos enquadrar dentro da noção de sustentabilidade ${ }^{63}$ ou das questões ambientais, não é uma ideia contemporânea. É possível traçar uma origem empírica de tais constatações até culturas e épocas mais antigas (GREIF, 2002; HARRIS, 1990; JAIN, 1982; THOMS, 2010).

No que diz respeito à origem do vegetarianismo, propriamente, as evidências mais aceitas dessa prática remontam à tradição indiana (BONTEMPO, 2003; CARNEIRO, 2003). Desde essa provável origem, já é possível encontrar um aspecto ambiental concomitante ${ }^{64}$.

O movimento em massa de adoção deste sistema alimentar ocorreu na Índia, século VI AEC, juntamente à transição de sociedades pastoris para sociedades agrícolas e ao aumento da população. Na região em questão, a limitação na criação de animais para o corte teria sido a forma de manter um núcleo populacional maior com uma quantidade menor de recursos (GREIF, 2002). Segundo Harris (1990) e Jain (1982), tal movimento, que inclusive teria sido incorporado e difundido posteriormente pelas tradições religiosas védicas ${ }^{65}$, foi também uma forma de evitar guerras e outros conflitos sociais.

Apesar das conjecturas que apontam a possível gênese do vegetarianismo na Índia, a economia de certos recursos através de uma alimentação baseada em vegetais não é uma concepção exclusiva dessa região, ou sequer do oriente. Se tomarmos o berço da civilização ocidental como exemplo, é possível identificar, nas palavras escritas por Platão, em seu diálogo socrático "República", escrito no século IV AEC, uma alusão a ideias que atualmente consideramos relacionadas à sustentabilidade. Na obra, há uma passagem em que Sócrates defende que a introdução da pecuária prejudica o equilíbrio de uma cidade, levando à necessidade de conquista de novos territórios e às guerras (PLATÃO, 2016).

\footnotetext{
${ }^{62} \mathrm{Ou}$, até mesmo, que defenda a abstenção de certos alimentos de origem animal.

${ }^{63}$ Tal como menores taxas de uso de recursos naturais e a redução do desmatamento. Segundo Perry e Grace (2015), a opção de se reduzir a ingestão produtos de origem animal envolve fortemente a ideia de "consumo sustentável" de Bryant e Goodman (2014).

${ }^{64}$ É preciso deixar claro que noções de ambiente e sustentabilidade são concepções próprias de nosso contexto moderno, muitos dos exemplos de constatações empíricas citados neste item não operam sob estas mesmas noções, mas possuem certas relações que podemos enquadrar no que Strathern (2004) definiria como "conexões parciais".

${ }^{65}$ Tais como o vaishnavismo, bramanísmo, vixnuísmo e outras tradições religiosas dentro da cultura hinduísta, cuja prática do vegetarianismo é um tido como um importante preceito (MACEDO, 2017), ainda que não seja explicitamente relacionado a questões ambientais em suas escrituras ou ensinamentos mais tradicionais.
} 
Segundo Thoms (2010), a concepção de um "vegetarianismo ambiental", apesar da emergência recente como conceito, possui um passado nitidamente identificável no século XVIII. É possível, por exemplo, citar a declaração do teólogo e filosofo britânico William Paley, que argumentava que "um pedaço de terra capaz de suprir comida de origem animal para a subsistência de dez pessoas, deveria sustentar, pelo menos, o dobro do número com grãos, raízes e leite" (PALEY, 1838, p. 343, tradução nossa).

Outro autor, contemporâneo e conterrâneo de Paley, expressou uma visão semelhante. Trata-se do filósofo e economista britânico Adam Smith. Em sua obra, "The Wealth of Nations", publicada em 1776, o autor expõe que "um milharal de produtividade moderada produz uma quantidade de comida para o homem muito maior que a melhor pastagem de igual extensão" (SMITH, 2007, p. 120, tradução nossa). Para Thoms (2010), as constatações comparativas das discrepâncias de produtividade de alimentos entre terras destinadas à agricultura e à pecuária influenciaram políticas econômicas utilitaristas e esforços para garantir a segurança alimentar e saúde de algumas populações ao longo da história ${ }^{66}$.

$\mathrm{Na}$ contemporaneidade, podemos citar algumas obras que exprimem perspectivas semelhantes e se destacam nesse sentido. O nutricionista e químico Henry Sherman (1919), em seu livro "Permanent gains from the food conservation movement", já defendia a dieta vegetariana como uma das melhores formas de poupar recursos alimentícios para soldados na Primeira Guerra Mundial. No entanto, a primeira publicação de impacto sobre o tema foi o livro "Diet for a small planet" de Frances Moore Lappé (1982). Em tal obra, que teve mais de dois milhões de cópias comercializadas, a autora discutia a participação da pecuária em diversas problemáticas, tais como destruição de ecossistemas e outras questões socioeconômicas como pobreza e desigualdade, através de uma abordagem que expunha fatores econômicos, ecológicos e sociais, (GREIF, 2002).

Outra obra com significativa importância foi o livro "Diet for a New America", de John Robbins (2012), originalmente lançado em 1987, que seguiu uma linha similar ao trabalho de Lappé, abordando também outros temas, como direitos dos animais e questões de saúde. Posteriormente, o livro "Beyong Beef: The rise and fall of the cattle culture", de

\footnotetext{
${ }^{66}$ Como, por exemplo, o caso de líderes nazistas que, durante épocas de escassez de alimentos nas décadas de 1930 e 1940, atacavam fazendeiros que utilizavam, para alimentar animais, grãos que poderiam estar sendo destinados ao povo alemão (CANTOR; BONAH; DÖRRIES, 2010). Para alguns autores na alemanha, inclusive, o vegetarianismo e as preocupações ambientais, são associadas a ideias de extrema direita e noções de superioridade racial, perspectiva que mostra uma visão muito contrária ao estereótipo do vegetarianismo ligado a movimentos de contracultura e posições políticas de esquerda (AZEVEDO, 2017).
} 
Jeremy Rifkin (1993), também aborda problemas ambientais e socioeconômicos associados à produção animal (GREIF, 2002).

Com o aumento mundial no consumo de carne nas últimas décadas e a respectiva expansão da indústria de produção animal em diversos países (HEINRICH BÖLL FOUNDATION, 2014), bem como com a crescente preocupação com os grandes problemas socioambientais modernos, toda a discussão dessa problemática foi, gradativamente, se tornando mais visível e sendo objeto de diversos estudos acadêmicos.

Já no século XXI, uma das publicações mais completas e de maior impacto sobre a temática foi o relatório "Livestock's long shadow: environmental issues and options", publicado pela Food and Agriculture Organization of the United Nations (FAO) (2006). Trata-se de um extenso trabalho científico, que envolveu a participação de especialistas de diversas áreas, no qual é apresentado o panorama de problemas ambientais diretamente relacionados com a pecuária industrial, juntamente aos potenciais técnicos e possíveis abordagens políticas para mitigação destes problemas. Segundo o estudo, "o setor da pecuária emerge como um dos dois ou três contribuintes mais significantes para os problemas ambientais mais sérios, em todas as escalas do local ao global" (FOOD AND AGRICULTURE ORGANIZATION OF THE UNITED NATIONS, 2006, p. XX, tradução nossa).

Observando os exemplos citados nos parágrafos anteriores, desde os povos indianos do século VI AEC, passando pelo diálogo socrático de Platão, os trabalhos dos dois filósofos ingleses, até os marcantes e populares livros da década de 80, é possível perceber a pluralidade de situações e contextos, em diversos aspectos. Sem o intuito de estabelecer um "vegetarianismo ambiental" anacrônico, que una todos os casos, é possível identificar certas conexões parciais (STRATHERN, 2004) entre tais constatações, feitas em realidades díspares:

- Comparativamente, produzir alimentos de origem animal ${ }^{67}$, de modo geral, demanda uma quantidade maior de certos recursos quando comparados a alimentos de origem vegetal.

\footnotetext{
${ }^{67}$ Especialmente a carne bovina, mas muitos dos casos citados também abordam problemas relacionados ao impacto da criação de aves, suínos e, até mesmo, do impacto da pesca e criação de peixes.
} 
- Em muitos contextos, a adoção de uma dieta com menos carne pode trazer benefícios, como a redução da necessidade de terras para a produção alimentar e a diminuição no uso de alguns recursos.

É preciso ressaltar, entretanto, que tais conexões são consideravelmente relativas. Os problemas ambientais associados a uma forma específica de alimentação variam de acordo com muitos de outros fatores, não apenas em função do consumo ou abstenção de carne ou produtos de origem animal. Por outro lado, como será demonstrado em seções posteriores deste trabalho, apesar de exceções, uma assimetria ambiental generalizada entre a produção de alimentos de origem animal e vegetal se verifica tanto no campo hipotético ${ }^{68}$ quanto na prática, o que explica o protagonismo do setor pecuário nas problemáticas ambientais modernas e justifica os diversos estudos acadêmicos que mostram que a adoção de DBP pode trazer significativos benefícios para o cenário socioambiental global ${ }^{69}$.

É significantemente amplo comparar, de maneira universal, dietas vegetarianas e onívoras. No entanto, observando as constatações empíricas e científicas resgatadas na revisão bibliográfica, é necessário reconhecer que a relação existente entre níveis baixos ou nulos de consumo de alimentos de origem animal e certos benefícios ambientais não é algo isolado ou inédito.

\subsubsection{Aspectos ecológicos e eficiência energética}

Para analisar as constatações que indicam disparidades ecológicas entre a produção animal e a produção vegetal de modo geral, bem como os dados que demonstram o protagonismo da pecuária industrial em grande parte dos problemas ambientais modernos em diversas escalas (FOOD AND AGRICULTURE ORGANIZATION OF THE UNITED NATIONS, 2006; HEINRICH BÖLL FOUNDATION, 2014), é preciso compreender certos princípios básicos da ecologia, mais especificamente as regras de como se dá a transferência de energia entre níveis tróficos nas pirâmides alimentares.

Grande parte da energia existente na biosfera em diversas formas, incluindo a energia química, que está presente nas moléculas dos alimentos que consumimos, possui como sua

\footnotetext{
${ }^{68}$ Vide a explicação sobre a pirâmide energética alimentar do item 2.2.2.

${ }^{69}$ Alguns exemplos destes estudos podem ser encontrados no capitulo 4 desta dissertação.
} 
fonte original a radiação solar que incide no planeta ${ }^{70}$. Esta radiação luminosa é captada por organismos autótrofos, como bactérias, algas e plantas, e é convertida pelo processo de fotossíntese. Tais organismos, também chamados de produtores primários, compõem a base de nossa pirâmide alimentar e sustentam as diversas formas de vida pertencentes a outros níveis tróficos, lhes fornecendo energia. No entanto, este montante de energia captado e convertido por esses organismos não estará disponível em sua totalidade para os consumidores primários ou para o resto da pirâmide alimentar. Na verdade, via de regra, uma parcela muito pequena será aproveitada (ODUM; BARRETT, 2008).

Aproximadamente $10 \%$ da energia da base é de fato absorvida e utilizada pelo nível superior, e assim sucessivamente, sendo que esse montante de $90 \%$ costuma ser gasto em processos metabólicos, acabando por se dissipar na forma de calor, nas fezes e transpiração (GREIF, 2002).

A Figura 1, um exemplo gráfico da pirâmide energética, ilustra esse processo. A energia de base dos produtores é de $10000 \mathrm{kcal} / \mathrm{g} / \mathrm{ano}$; já no nível trófico dos consumidores primários, sustentados pelo consumo dos produtores, há uma perda de $90 \%$ da energia, e assim por diante.

Isso significa que optar por DBP, como é o caso do vegetarianismo, significa escolher basear a alimentação em níveis mais baixos da pirâmide alimentar. Por outro lado, a inclusão de carnes e produtos de origem animal levariam à necessidade de uma quantidade de energia muito maior para que se sustente tais níveis superiores ${ }^{71}$ (GREIF, 2002; LAMIM-GUEDES, 2012).

\footnotetext{
${ }^{70}$ Com exceção da energia oriunda do decaimento de isótopos radioativos no interior do planeta, a qual gera calor no interior do planeta e mantém o magma do núcleo da terra em estado líquido, mas que não influencia tanto na biosfera quanto a energia solar (GROTZINGER; JORDAN, 2014).

${ }^{71}$ É preciso ressaltar que as pirâmides alimentares podem ser construídas à partir de três fatores: número de indivíduos, biomassa e energia. Nos três casos, os níveis trófico superiores também costumam decrescer similarmente ao comportamento exemplificado da pirâmide energética. Ou seja, o raciocínio geralmente também vale quando consideramos a quantidade de biomassa ou o número de indivíduos (PELISSARI; TEIXEIRA, 2013; RICKLEFS, 2010).
} 
Figura 1 - Pirâmide alimentar energética

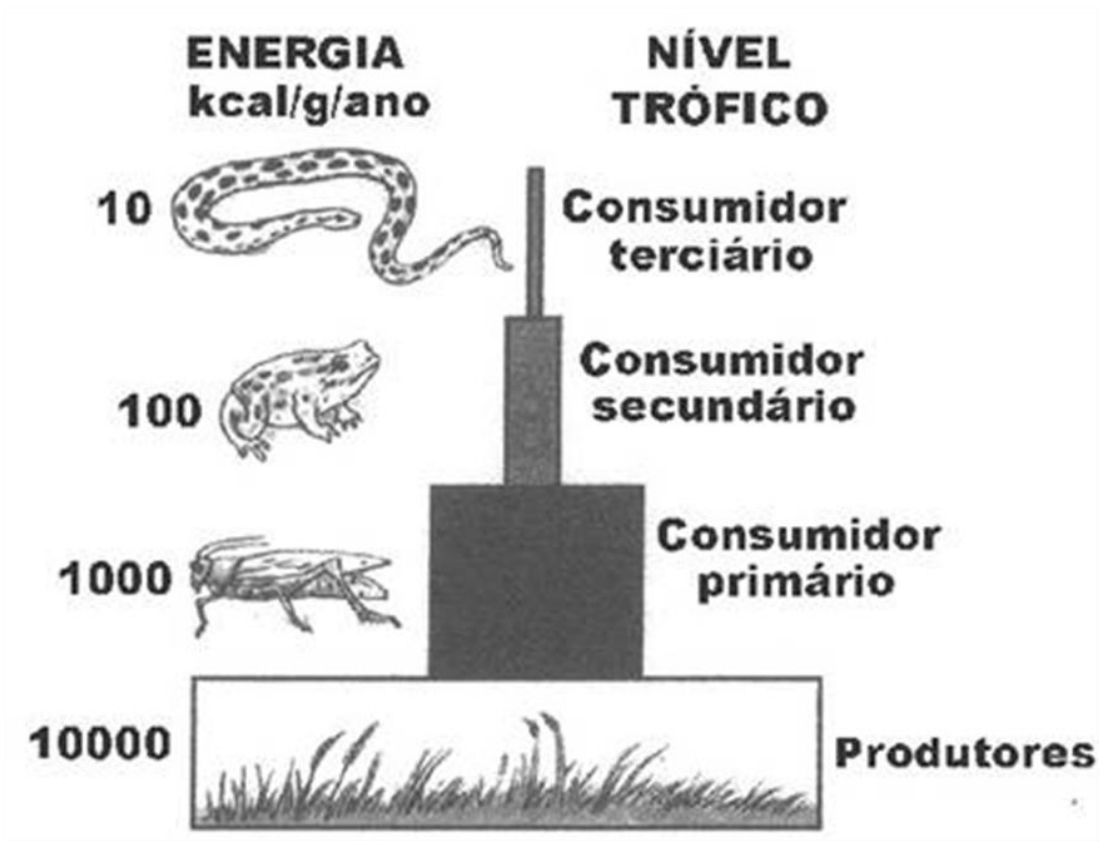

Fonte: (LAMIM-GUEDES, 2012).

Em suma, este raciocínio explica o fato de que, em sistemas pecuários intensivos ${ }^{72}$, para cada caloria presente na carne de um animal, são gastas, em média, dez calorias para sua alimentação (CASSIDY et al., 2013). Já em sistemas extensivos ${ }^{73}$ de gado bovino, são necessárias grandes extensões de áreas para pastagem, as quais seriam muito mais produtivas em termos de biomassa e energia caso fossem disponibilizadas para agricultura (GUIDOTTI et al., 2015). Ainda que tais informações configurem médias e cálculos genéricos, tal fator se verifica a maior parte das vezes, se levarmos em conta que grande parcela da produção global de grãos é destinada para alimentar gado em países com forte produção animal intensiva (HEINRICH BÖLL FOUNDATION, 2014) e que, por outro lado, existe o predomínio das pastagens como atividade que mais ocupa territórios em países com uma forte pecuária extensiva, como é o caso do Brasil (BARONA et al., 2010; GUIDOTTI et al., 2015; RIVERO et al., 2009). Também é o que explica que, em média, sejam necessárias áreas ao menos três

\footnotetext{
${ }^{72}$ Sistemas de criação de animais em confinamento e que envolvem, de modo geral, um maior grau de procedimentos tecnológicos. Os principais animais utilizados em produções intensivas são: bovinos, bufalinos, suínos, ovinos, caprinos, patos, frangos, perus e coelhos (HEINRICH BÖLL FOUNDATION, 2015). Também pode ser chamada de pecuária super-intensiva (MELADO, 2007).

${ }^{73}$ Sistemas de criação de animais baseado na ocupação de grandes áreas, o qual, geralmente, envolve um menor grau de procedimentos tecnológicos.
} 
vezes maiores para alimentar alguém que inclua alimentos de origem animal no cardápio ${ }^{74}$ do que uma pessoa com uma dieta vegetariana (CASSIDY et al., 2013).

Os percentuais de transferência de energia, no entanto, tal como os recursos necessários e os impactos ambientais de criar animais, variam de acordo com o ecossistema em questão e os organismos envolvidos, dentre outros fatores (FOOD AND AGRICULTURE ORGANIZATION OF THE UNITED NATIONS, 2006; HEINRICH BÖLL FOUNDATION, 2014; ODUM; BARRETT, 2008). Mas, apesar de existirem diversos casos e exceções, a disparidade energética da produção animal frente à produção agrícola, se verifica na maior parte das vezes. No Brasil, por exemplo, segundo estudo de Guidotti et al. (2015),

\begin{abstract}
(...) a agricultura produz uma quantidade muito maior de proteína e energia do que a pecuária e com eficiência muito superior. Em 2006 a produção total de proteína da agricultura foi 25 vezes maior do que da pecuária, ocupando uma área 2,6 vezes menor que a de pastagem. As projeções para 2020 indicam que esta diferença deve se acentuar (GUIDOTTI et al., 2015, p. 1).
\end{abstract}

Tal disparidade energética faz com que o fluxo de matéria e energia, bem como os recursos necessários para a produção animal seja, comparativamente, mais intenso do que a produção vegetal. Isso acaba por implicar em um maior grau de externalidades e impactos ambientais envolvidos com a pecuária do que com a agricultura ${ }^{75}$ (BARONI et al., 2007). Segundo o relatório de 2014 desenvolvido pelo Conselho Empresarial Brasileiro para o Desenvolvimento Sustentável (CEBDS), em parceria com a Agência Alemã para a Cooperação Internacional (GIZ), para cada 1 milhão de reais de receita produzida com pecuária extensiva no Brasil, geram-se 22 milhões de reais de impacto ambiental ${ }^{76}$ que não são compensados ou sequer contabilizados. Para estabelecer um comparativo, segundo o mesmo estudo, para cada 1 milhão de reais de receita gerada com produção de soja no Brasil, os impactos não chegam nem a 3 milhões de reais ${ }^{77}$ (CARREIRA; RE'EM; TARIN, 2015).

Entretanto, sob outro ponto de vista, a carne também pode ser considerada um alimento energeticamente eficiente. Alimentos de origem animal, de modo geral, costumam

\footnotetext{
${ }^{74}$ De acordo com padrões de dieta ocidentais em países desenvolvidos.

${ }^{75}$ Sendo a pecuária bovina, mais especificamente a extensiva, a atividade mais extrema nesse aspecto.

${ }^{76}$ Seguindo este raciocínio, se os custos de tais externalidades fossem contabilizados no preço da carne bovina brasileira, sua produção, na verdade, causaria prejuízos e seria inviável economicamente (HEINRICH BÖLL FOUNDATION, 2015).

${ }^{77}$ Vide Tabela 3, no item 3.1.1.
} 
ter maior quantidade de energia por massa do que os de origem vegetal. A alta densidade calórica $^{78}$, juntamente com a densidade nutricional, dão à carne, muitas vezes, o status de alimento nobre e extremamente nutritivo (MEDEIROS, 2008; MONTANARI, 2008). Isso frequentemente transparece nos discursos daqueles que defendem o sistema-carne, pois, segundo essa visão exemplificada no trabalho de Sordi (2013) “o boi seria uma espécie de máquina capaz de transformar a energia humanamente inaproveitável da fibra de celulose em energia que somos capazes de assimilar, como carne, leite e derivados" (SORDI, 2013, p.111).

A controvérsia entre estes dois pontos de vista, da carne eficiente ou ineficiente no aspecto energético, depende, sobretudo, se a consideramos isoladamente, observando apenas sua densidade calórica, ou se a pensamos inserida em uma cadeia alimentar, levando em conta o sistema de produção e as trocas e fluxos de matéria e energia envolvidas.

Adotando uma perspectiva mais sistêmica e ecológica, é possível compreender, portanto, que uma ineficiência energética generalizada da produção de alimentos de origem animal frente aos alimentos de origem vegetal, explica certas assimetrias entre pecuária e agricultura no que diz respeito a aspectos ambientais (HERRERO et al., 2015). Por conta disso, as DBP, como é o caso do vegetarianismo, são frequentemente apontadas como sendo energeticamente mais eficientes e, de modo geral, mais sustentáveis (HERRERO et al., 2015; PIMENTEL; PIMENTEL, 2003; SABATÉ; SORET, 2014; VINNARI; VINNARI, 2014). Neste fator ecológico, portanto, reside a justificativa teórica mais basal para o vegetarianismo ambiental (SOUZA, 2017).

\subsubsection{Vegetarianismo ambiental}

Nas últimas décadas temos observado o crescimento do movimento ambientalista, o aumento da preocupação com as grandes problemáticas socioambientais modernas em diversas esferas, as conferências internacionais para a conservação da biodiversidade e para as mudanças climáticas. O vegetarianismo possui uma relação com todo este panorama, dado que a terceira motivação mais comum para a sua adoção são questões relacionadas as meio

\footnotetext{
${ }^{78} \mathrm{O}$ conteúdo energético de 100 gramas de carne bovina magra assada, por exemplo, é de 213 kcal (ROÇA, 2011).
} 
ambiente (ABONIZIO, 2016; BEARDSWORTH; KEIL, 1992; FOX; WARD, 2008; MISHORI, 2017; RUBY, 2012).

Tal relação existente entre vegetarianismo e meio ambiente se embasa, de modo geral, na justificativa de que, atualmente, a indústria de produção animal é um dos setores ambientalmente mais impactantes, do nível local ao global (CAPUTO et al., 2012; FOOD AND AGRICULTURE ORGANIZATION OF THE UNITED NATIONS, 2006; HEINRICH BÖLL FOUNDATION, 2014; SCHUCK; RIBEIRO, 2015; WALTERS, 2012), e que as dietas vegetarianas se apresentariam como uma alternativa alimentar mais sustentável frente a esse cenário (CAPUTO et al., 2012; FOX, 2000; FOX; WARD, 2008; GREIF, 2002; MISHORI, 2017; SABATÉ; SORET, 2014; WALTERS, 2012).

O conceito de "vegetarianismo ambiental", que vem emergindo em trabalhos acadêmicos, livros, reportagens na mídia e em outros meios de comunicação, expressa bem a perspectiva do vegetarianismo como um possível caminho para a sustentabilidade alimentar (CANTOR; BONAH; DÖRRIES, 2010; CAPUTO et al., 2012; MISHORI, 2017; MORTARA, 2013; SOUZA, 2017; SUBRAMANIAM, 2011; WALTERS, 2012). Apesar do uso frequente do termo na bibliografia internacional e do seu crescente emprego, seja em artigos científicos ou na mídia e internet de modo geral (CAPUTO et al., 2012), não foram encontrados trabalhos brasileiros que explorem especificamente este conceito e as ideias que o sustentam ${ }^{79}$.

Ainda seriam necessários mais estudos, especialmente de caráter etnográfico, para compreender melhor os "vegetarianos ambientais" 80 e se há uma concordância generalizada desse termo entre os atores desse cenário e os estudiosos do assunto. No entanto, dado o que foi exposto, seria possível arriscar uma definição para o "vegetarianismo ambiental" como a abstenção, ou até mesmo a redução ${ }^{81}$, do consumo de alimentos de origem animal na dieta humana por motivações de caráter ambiental.

\footnotetext{
${ }^{79} \mathrm{Na}$ literatura científica brasileira, existem diversos trabalhos que abordam o vegetarianismo como um todo. No entanto, o cenário atual carece de estudos que abordem com exclusividade a dimensão ambiental do tema. A única exceção encontrada, como já mencionado na nota de rodapé 8 , trata-se do artigo produzido pelo próprio autor desta dissertação, intitulado "Vegetarianismo ambiental", publicado no XVIII Encontro Nacional da Associação Nacional de Pós-Graduação e Pesquisa em Ambiente e Sociedade (SOUZA, 2017).

${ }^{80}$ Possíveis adeptos do vegetarianismo cuja motivação primária sejam questões ambientais.

${ }^{81}$ As definições de vegetarianismo não se limitam apenas a uma abstenção total de alimentos de origem animal de qualquer espécie, como demonstrado no item 2.1 desta dissertação.
} 
É possível, também, utilizar o termo para se referir à dimensão ambiental dentro do vegetarianismo ${ }^{82}$, ainda que, geralmente, esta não se apresente como uma justificativa primária e que ela mescle ou se confunda com motivações de outra natureza, tais como questões de ética ou de saúde.

Sabe-se que, no que se refere à esfera acadêmica, o tema do vegetarianismo tem levantado crescentes discussões e controvérsias (AZEVEDO, 2013; SORDI, 2013), apresentase como um campo de estudo em ascensão (RUBY, 2012). Logo, a parcela ambiental do tema apresenta uma interessante possibilidade de pesquisa, não só por este fator, mas pela própria importância das discussões de segurança alimentar e pela maneira com que envolve os grandes problemas ambientais no cenário global.

Também é preciso ressaltar que, apesar de não ser correto nomear a existência de um "veganismo ambiental" a princípio, tendo em vista que o veganismo se define por contornos primordialmente éticos, podemos afirmar que as motivações ambientais, sem dúvida, integram o conjunto de justificativas veganas e estão presentes em seus debates (ABONIZIO, 2013).

Revisando a literatura científica sobre o tema, podemos observar que as principais justificativas que embasam o vegetarianismo ambiental se baseiam, sobretudo, em constatações e estudos que mostram os problemas socioambientais da indústria pecuária. É preciso ressaltar que, por mais que haja uma grande quantidade de tópicos importantes que podem ser discutidos neste âmbito, tratar de todas as relações entre os problemas socioambientais modernos e a indústria da carne seria uma abordagem equivocada para esta dissertação, pois escapa ao foco deste trabalho, o vegetarianismo, e, além disso, seria redundante, tendo em vista que existem outros trabalhos que já o fazem ${ }^{83}$. Desdobrar e explorar, com algum aprofundamento, as controvérsias sociotécnicas em todas estas relações seria, ainda, um esforço demasiado para uma dissertação de mestrado.

No entanto, faz-se necessário apresentar algumas das principais informações e dados que demonstram a relevância do tema, auxiliando a circunscrever a rede de assuntos que o

\footnotetext{
${ }^{82}$ Trabalhos como o de Caputto (2012) e de Mishori (2017) utilizam o conceito de "vegetarianismo ambiental" para se referir a um movimento e o debate público de suas possibilidades.

${ }^{83}$ Como, por exemplo, o trabalho de Schuck e Ribeiro (2015), além do relatório da Organização das Nações Unidas para Agricultura e Alimentação em relatório de 2006, uma das publicações mais completas e proeminentes sobre o tema (FOOD AND AGRICULTURE ORGANIZATION OF THE UNITED NATIONS, 2006).
} 
vegetarianismo ambiental toca e dando uma noção do alcance e natureza do debate, especialmente tendo em vista o conhecimento científico.

\subsubsection{Justificativas e relevâncias científicas do vegetarianismo ambiental: problemas ambientais da pecuária}

Em nossa sociedade moderna, anualmente, criamos e abatemos mais de setenta bilhões de animais terrestres, sem contar com um montante muito maior de animais aquáticos, para nosso consumo alimentar ${ }^{84}$. Levando em conta que cada um destes animais necessita de terra, água, alimento e energia, percebe-se que esse quadro pode causar alterações em ecossistemas, além de gerar grandes quantidades de resíduos que vão para atmosfera, solo água (FOOD AND AGRICULTURE ORGANIZATION OF THE UNITED NATIONS, 2018; HEINRICH BÖLL FOUNDATION, 2014). Sendo assim, é possível ter uma rápida noção da magnitude dos fluxos de matéria e energia envolvidas nessa indústria.

Mesmo existindo perspectivas diferentes para observar os dados de uso e ocupação do solo pela indústria de produção animal ${ }^{85}$, de modo geral, a pecuária é apontada como uma das atividades que mais ocupa territórios atualmente. Existem diversas formas de quantificar a ocupação deste setor. O artigo de Foley et al. (2011) apresenta alguma destas: segundo o trabalho, cerca de $75 \%$ das terras agricultáveis do mundo são utilizadas, direta ou indiretamente $^{86}$, pela pecuária, seja por áreas de pastagem ou por cultivos agrícolas que são destinados à alimentação de animais, como mostra o gráfico na Figura 2. Mais precisamente,

\footnotetext{
${ }^{84}$ É necessário pontuar, a partir deste subcapítulo, que os impactos ambientais relacionados com a pecuária dizem respeito, sobretudo, à produção animal que segue lógicas industriais, em grande escala e velocidade, as quais suprem a demanda de uma sociedade de consumo em massa. Outras lógicas de produção animal, que não seguem estes padrões e que, por diversos motivos, são mais sustentáveis, não devem ser associadas a tais problemas ambientais.

${ }^{85}$ Um dos pontos que causam divergências neste tópico é se as áreas que são utilizadas para a produção de forragem deveriam ser consideradas como solo ocupado para produção animal ou não. De acordo com a maior parte das pesquisas revisadas, o padrão identificado é de que o território ocupado diretamente pela agricultura para produção de forragem é considerado separadamente à pecuária, ainda que haja essa relação indireta (ESHEL et al., 2014; FOLEY et al., 2011; FOOD AND AGRICULTURE ORGANIZATION OF THE UNITED NATIONS, 2006).

${ }^{86}$ Diretamente, como pastagem, ou indiretamente, como cultivos que são destinados à alimentação de animais. Nessa perspectiva, o montante total das terras agricultáveis destinadas a pecuária equivalem, portanto, a, aproximadamente, 3,73 bilhões de hectares (FOLEY et al., 2011).
} 
$26 \%$ das terras não cobertas por gelo do planeta são utilizadas como pastagem, enquanto $12 \%$ são destinadas para a agricultura ${ }^{87}$ (FOLEY et al., 2011).

Figura 2 - Uso das terras agricultáveis do planeta

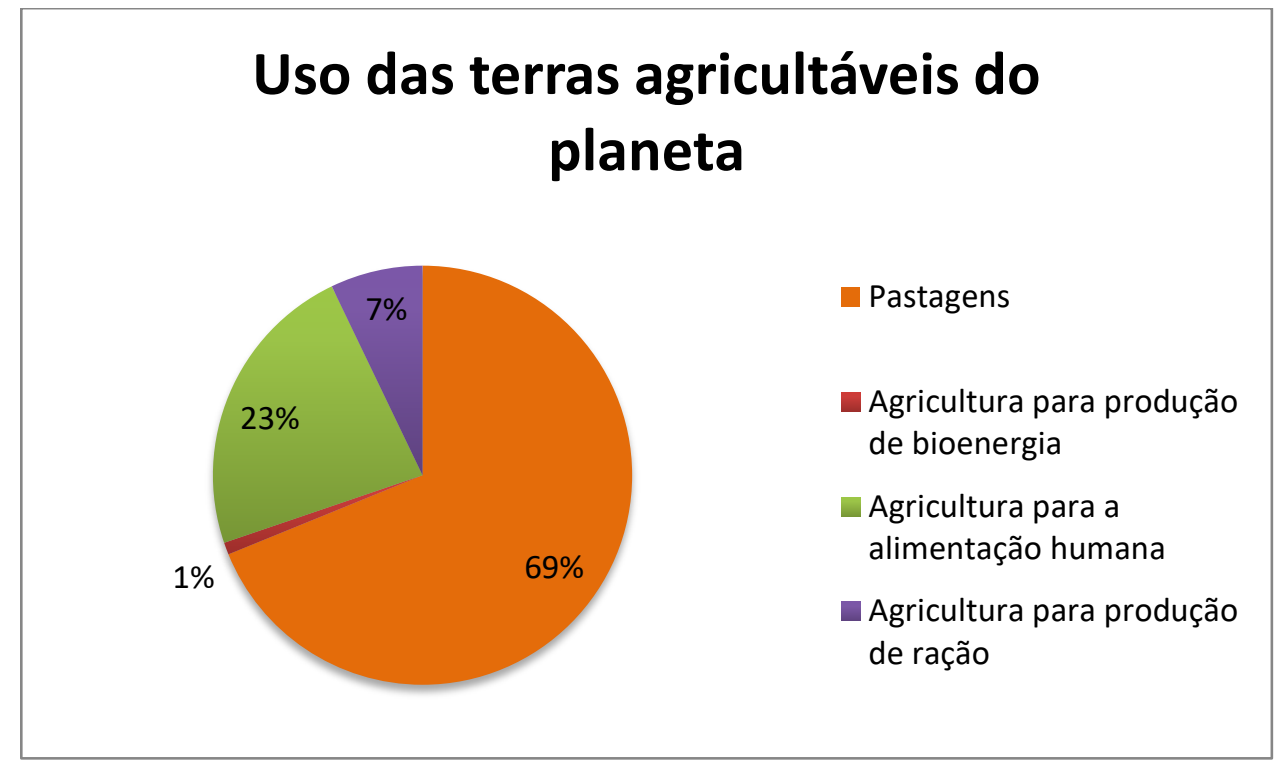

Fonte: Adaptado de Foley et al., 2011.

Um fato que é necessário ressaltar é que, apesar de utilizar a maioria das terras agricultáveis do planeta, a produção animal fornece apenas $33 \%$ das proteínas consumidas no planeta e apenas $17 \%$ do consumo mundial de quilocalorias ${ }^{88}$ (ROJAS-DOWNING et al., 2017).

No Brasil, a situação com relação à ocupação do solo não é diferente. A criação de gado bovino desponta como a atividade econômica que mais ocupa território no país, sendo que, em segundo lugar, está a produção de soja, a qual é também associada à produção de carne (HEINRICH BÖLL FOUNDATION, 2015; INSTITUTO BRASILEIRO DE GEOGRAFIA E ESTATÍSTICA, 2006). Segundo os dados mais atualizados sobre o tema, aproximadamente $20 \%$ do território nacional é coberto por pastagens ${ }^{89}$ (ASSOCIAÇÃO BRASILEIRA DAS INDÚSTRIAS EXPORTADORAS DE CARNES, 2018; HEINRICH

\footnotetext{
${ }^{87}$ Sendo que $35 \%$ da massa total de cultivos agrícolas produzidos no mundo são alocados para a alimentação de animais (FOLEY et al., 2011).

${ }^{88}$ Isso corrobora com a perspectiva de que pecuária seria uma forma de produzir alimentos energeticamente ineficiente, conforme apresentado no item 2.2.2.

${ }^{89}$ É preciso reforçar o fato de que as pastagens, sejam elas naturais ou artificiais, vem sendo ocupadas majoritariamente pela pecuária bovina (AMARAL et al., 2012; THÉRY; MELLO, 2005).
} 
BÖLL FOUNDATION, 2015), enquanto a agricultura, por sua vez, ocupa $8 \%$ (EMPRESA BRASILEIRA DE PESQUISA AGROPECUÁRIA, 2017).

Resumidamente, se considerarmos o planeta como um todo, há uma predominância da pecuária como atividade antrópica que mais ocupa terras, especialmente se levarmos em conta a parcela da produção vegetal que é destinada para alimentação de animais. Apesar disso, a quantidade de alimentos, calorias e proteínas produzidas pela agricultura é consideravelmente maior que a pecuária ${ }^{90}$, diferenciação que se acentua em países com grande atividade de pecuária bovina extensiva, como é o caso do Brasil (FOOD AND AGRICULTURE ORGANIZATION OF THE UNITED NATIONS, 2006; GUIDOTTI et al., 2015).

Um dos problemas ambientais centrais inseridos dentro da questão de uso e ocupação do solo para a indústria de produção animal é o desmatamento e suas respectivas consequências. Desde os anos 70, o Brasil tem sofrido extensivo desmatamento, em especial na região da Amazônia, por conta da atividade pecuária (BARONA et al., 2010). Aproximadamente $80 \%$ da área desmatada no país entre 1990 e 2005 é atribuída à pecuária, por conta da criação de pastos (FOOD AND AGRICULTURE ORGANIZATION OF THE UNITED NATIONS, 2016).

A Amazônia representa um dos principais biomas desmatados nas últimas décadas. Entre os anos de 1990 e 2002, 80\% do crescimento do gado bovino brasileiro ocorreu nesta região, em especial na região conhecida como "arco do desmatamento"91 (KAIMOWITZ et al., 2017). Ao todo, a maior parte da área desmatada na Amazônia foi transformada em pastagem (EMPRESA BRASILEIRA DE PESQUISA AGROPECUÁRIA; INSTITUTO NACIONAL DE PESQUISAS ESPACIAIS, 2011).

Enquanto a Amazônia representa a principal fronteira de expansão da pecuária, no cerrado a atividade se consolidou de maneira contundente, uma vez que concentra a maior parte da produção do país. Cerca de um terço de seu território é ocupado por pastagens (MINISTÉRIO DO MEIO AMBIENTE, 2011), as quais abrigam, pelo menos, $40 \%$ do rebanho bovino do Brasil, além de $42 \%$ da área desse bioma ser ocupada por plantações de soja (HEINRICH BÖLL FOUNDATION, 2015).

\footnotetext{
${ }^{90}$ Isso se explica pela ineficiência ecológica descrita no capítulo 1.2.2.

${ }^{91}$ Área da Amazônia legal onde ocorrem altos índices de desmatamento, principalmente por conta da criação de pastagens. Trata-se de uma faixa que representa a principal fronteira de expansão agropecuária do país e se estende do Maranhão até o Acre, passando pelos estados do Pará, Tocantins, Mato Grosso, Amazonas e Roraima (DOMINGUES; BERMANN, 2012).
} 
Além disso, outros biomas brasileiros com significativa presença da indústria pecuária são o Pantanal e os Pampas. Em ambos os casos a criação de gado bovino prevalece como a principal forma de uso da terra e há também uma forte correlação com o desmatamento (ABDON et al., 2006; ECHER et al., 2015; MINISTÉRIO DO MEIO AMBIENTE, 2007).

Apesar dos dados e do notável protagonismo da pecuária para o uso do solo e desmatamento no Brasil, limitar a questão somente a esse setor é um tanto reducionista. $\mathrm{O}$ cenário de desmatamento atual não é algo simples ou que possui apenas uma causa, trata-se um fenômeno mais complexo.

Existem diversos ciclos de desmatamento, que podem ser identificados nas dinâmicas brasileiras, sendo que, cada um destes, pode envolver causas diretas, tais como: a conversão de áreas florestais para agricultura ou criação de gado, exploração madeireira, mineração, incêndios; e causas indiretas, tais como: política inadequada de investimentos em infraestrutura, subsídios para o agronegócio, ausência de governança e fiscalização adequada por parte do governo, problemas fundiários, demanda por produtos florestais, situação do mercado e dos preços de produtos cultivados em áreas antes ocupados por florestas, dentre outros (FUNDAÇÃO BRASILEIRA PARA O DESENVOLVIMENTO SUSTENTÁVEL, 2010). No entanto, apesar da complexidade do assunto e da multiplicidade de fatores, é preciso reconhecer, dadas as estatísticas sobre o uso do solo, que a produção animal é protagonista na ocupação do território brasileiro.

Devido a esta grande capacidade de ocupar áreas, aponta-se, frequentemente, a pecuária como fator antrópico de maior impacto na perda de habitats, representando o setor que mais influencia na taxa de extinção de espécies globalmente (FOOD AND AGRICULTURE ORGANIZATION OF THE UNITED NATIONS, 2006; MACHOVINA; FEELEY; RIPPLE, 2015). Existem estudos que indicam que uma redução no consumo de carne pela população mundial pode ser o fator chave para a diminuição da perda da biodiversidade futura (MACHOVINA; FEELEY; RIPPLE, 2015) e tal redução teria um potencial de, sozinha, evitar a perda da biodiversidade futura em até $60 \%$ até 2050 (NETHERLANDS ENVIRONMENTAL ASSESSMENT AGENCY, 2010).

Além disso, água, alimentos, energia, combustíveis e outros insumos são produzidos e/ou alocados em grandes quantidades, sendo que, de modo geral, a indústria de produção animal é uma das que mais utiliza recursos (FOOD AND AGRICULTURE ORGANIZATION OF THE UNITED NATIONS, 2006; STAVE; KOPAINSKY, 2015). 
Quando se discute a redução ou abstenção do consumo de produtos de origem animal por motivações socioambientais, a questão dos recursos naturais também acaba sendo abordada.

O elevado gasto de combustíveis fósseis da pecuária em comparação à agricultura, por exemplo, é um fator frequentemente levantado. Segundo relatório da FAO (2006), produzir 1 quilograma $(\mathrm{kg})$ de carne consome 13 vezes mais combustível fóssil do que um $1 \mathrm{~kg}$ de alimentos de origem vegetal.

No que diz respeito ao consumo de cultivos, boa parte do gado criado atualmente não se alimenta apenas de pasto, mas, nos sistemas produtivos industriais, sua forragem pode consistir em milho, soja, trigo dentre outros grãos. Mesmo nos EUA, onde grande parte do cultivo de milho é destinado para a produção de etanol, $44 \%$ é destinada para suprir a alimentação de animais na pecuária. Na União Europeia (UE), 45\% do trigo é utilizado para mesmo fim (HEINRICH BÖLL FOUNDATION, 2015). Segundo dados da FAO (2006), mais de $97 \%$ do farelo de soja e $60 \%$ da produção global de cevada e milho são destinados para alimentar animais de corte. No final das contas, diversos alimentos acabam sendo investidos na produção de carne ao invés de serem alocados diretamente para a alimentação humana. Entretanto, o principal problema apontado por quem argumenta contra a produção animal industrial seria uma suposta perda envolvida nesse processo (GREIF, 2002; LAMIMGUEDES, 2012; SORDI, 2013), sendo que, para a produção de um $1 \mathrm{~kg}$ de carne bovina são necessários, em média, $7 \mathrm{~kg}$ de ração ${ }^{92}$ (FOOD AND AGRICULTURE ORGANIZATION OF THE UNITED NATIONS, 2006).

Claro que estas informações que relacionam quantidade de alimentos necessários para a produção animal, citadas anteriormente, são médias que variam de local para local; entretanto, elas expressam um uso ineficiente de recursos vegetais na produção animal, em conformidade com as disparidades ecológicas citadas no item 2.2.2. De modo geral, para cada caloria presente na carne de um animal criado em sistemas intensivos, são gastas dez calorias para sua alimentação (CASSIDY et al., 2013). Além disso, se considerarmos a quantidade de alimentos utilizada para a produção animal, seria possível alimentar cerca de 3,5 bilhões de seres humanos, metade da população do planeta (ESTEVE, 2017). Por conta destes números, muitas vezes é discutida a relação da indústria de produção animal com a fome (ABONIZIO, 2016).

\footnotetext{
${ }^{92}$ Existem trabalhos que apontam números ainda maiores, como 18 quilos de grão para cada quilo de carne (SLYWITCH, 2010).
} 
Apesar de haver debates e controvérsias sobre o assunto, é necessário salientar que a problemática da fome é complexa e não se trata apenas da simples oferta de alimentos, mas envolve outros fatores, como problemas com distribuição e desperdício de alimentos e, sobretudo, a pobreza (YASBEK, 2003). A redução do consumo de produtos de origem animal, por si, não é suficiente para reduzir a fome no mundo (AZEVEDO, 2013). Para dar um exemplo, o aumento significativo da produção e produtividade agrícola, propiciado pela "revolução verde", não implicou em um maior acesso aos alimentos para as populações mais pobres (MAZOYER; ROUDART, 2010). No entanto, é possível identificar que as altas taxas de consumo de carne influenciam nos preço de grãos ${ }^{93}$ e nas dinâmicas de uso da terra da agricultura $^{94}$, além de causar outros impactos, no sentido de concentrar a posse das terras e prejudicar a segurança alimentar ${ }^{95}$, acabando por influenciar, ainda que indiretamente na questão da fome (ESTEVE, 2017; HEINRICH BÖLL FOUNDATION, 2015). É possível identificar, portanto, controvérsias e complexidades no que diz respeito aos impactos da pecuária industrial na problemática da fome.

Dentro deste tópico maior, que questiona o elevado consumo de recursos por parte da produção animal industrializada, há um debate em torno do gasto de água desse setor (SORDI, 2013). Apesar da maior parte da água utilizada no mundo ser destinada à agricultura, estimativas indicam que pelo menos um terço do montante de água gasto no planeta acaba sendo destinado à pecuária, não apenas para dessedentação de animais, mas, especialmente, para produção de forragem e ração, o que estaria dentro da parcela maior atribuída à agricultura (HEINRICH BÖLL FOUNDATION, 2015).

Um dado frequentemente levantado é que são necessários, em média, 15500 litros de água para a produção de $1 \mathrm{~kg}$ de carne bovina ${ }^{96}$, enquanto, o gasto da produção de um $1 \mathrm{~kg}$ de vegetais ou cereais é, geralmente, dez vezes menor (MEKONNEN; HOEKSTRA, 2012). Segundo um estudo de Hoekstra e Mekonnen (2011), 22\% da pegada hídrica da humanidade vêm do consumo de carne, configurando o segundo maior gasto, seguido pelo consumo de

\footnotetext{
${ }^{93}$ Apesar disso, é preciso ressaltar que tal influência nos preços não é vertiginosa e possui limitações sólidas. Segundo Abramovay (2000), o aumento futuro no consumo de carne, por parte dos países em desenvolvimento, não causará uma drástica explosão nos preços de cereais e oleaginosas.

94 Devido à demanda agrícola sobre a produção de forragem que alimenta animais criados em sistemas intensivos.

${ }^{95} \mathrm{O}$ item 3.1.1 aborda mais profundamente o tema.

${ }^{96}$ Existem estudos que citam números ainda maiores, chegando até mesmo à 100 mil litros de água por quilo de carne bovina produzida (WALDMAN, 2003).
} 
leite de derivados ${ }^{97}$. É necessário ressaltar que estes números são médias mundiais e, portanto, variam muito de acordo com local e outros fatores. Uma vaca criada em sistemas intensivos, por exemplo, consome muito mais água do que as que estão em extensivos (HEINRICH BÖLL FOUNDATION, 2015). Em outro estudo, de Herrera et al. (2015), estima-se que a pecuária utiliza entre $25 \%$ e $32 \%$ de toda a água doce do planeta.

A água inserida dentro do processo produtivo de alguma mercadoria, muitas vezes referida como água virtual, nem sempre é levada em conta quando determinamos os custos de sua produção. Quando exportamos ou circulamos produtos de origem animal, estamos, portanto, exportando água virtual através dele, aumentando a pressão sobre esse recurso e contribuindo, muitas vezes, para a escassez hídrica em certos locais. Sob este aspecto, o Brasil aparece como o segundo maior exportador de água virtual do mundo, por conta de seus produtos agropecuários (HOEKSTRA; MEKONNEN, 2012).

Segundo previsões, se o consumo de carne continuar crescendo, a quantidade necessária de água para cultivar forragem pode dobrar até o meio do século. Se considerarmos os panoramas atuais e futuros om relação à escassez hídrica, somados aos cenários de aumento na demanda por carne, a injeção desse recurso na pecuária se tornaria cada vez mais questionável (HEINRICH BÖLL FOUNDATION, 2015), o que posicionaria a produção e o consumo de carne como uma grande problemática no que diz respeito à escassez hídrica, ainda que haja toda uma controvérsia a respeito do tema (SORDI, 2013).

É possível até mesmo conectar o tópico dos recursos hídricos e do desmatamento pela indústria pecuária, se levarmos em conta os "rios aéreos" descritos por Nobre (2014). Nesse raciocínio, o desmatamento na Amazônia, fomentado, sobretudo, pela abertura de pastos, acaba por prejudicar os fluxos de evapotranspiração, que abastecem a atmosfera com umidade, a qual alimenta chuvas nas regiões Sul e Sudeste do Brasil. Ou seja, a produção de bois na Amazônia possui uma relação, ainda que indireta, com a precipitação em São Paulo por exemplo, e portanto, com a situação de reservatório de água que abastecem grandes populações urbanas.

A problemática da poluição ambiental desponta como um dos tópicos mais salientes dentro da discussão do vegetarianismo ambiental. Uma boa parcela do debate se baseia em uma argumentação que aborda a poluição gerada pela indústria de produção animal, ainda que

\footnotetext{
${ }^{97}$ Que equivalem a 7\% da pegada hídrica (HOEKSTRA; MEKONNEN, 2012).
} 
também haja controvérsias a respeito. A questão do aquecimento global desponta como a mais discutida dentro do assunto (CAPUTO et al., 2012).

A volatilização de compostos diversos e, de modo geral, as emissões na atmosfera associadas à indústria de produção animal, tem-se tornado, cada vez mais, uma grande preocupação socioambiental (FOOD AND AGRICULTURE ORGANIZATION OF THE UNITED NATIONS, 2006, 2013a; GOODLAND; ANHANG, 2009; HERRERO et al., 2015). As emissões de gases do efeito estufa, em especial o metano $\left(\mathrm{CH}_{4}\right)$, oriundas da cadeia produtiva da pecuária industrial, possuem um papel central em toda essa discussão. Apesar disso, outros fatores são colocados em pauta no que diz respeito à poluição atmosférica: emissões de amônia, ácidos graxos, gás sulfídrico, o próprio dióxido de carbono $\left(\mathrm{CO}_{2}\right)$, dentre outros (HEINRICH BÖLL FOUNDATION, 2014). São assuntos que aparecem frequentemente na literatura científica e, além disso, são colocados em pauta em disputas públicas, quando se discute os problemas ambientais do consumo de produtos de origem animal.

Segundo relatório da World Wide Fund for Nature (WWF), cerca de 36\% da pegada ecológica paulistana ${ }^{98}$ se dá pelo consumo de produtos de origem animal, enquanto os produtos de origem vegetal correspondem a $18 \%{ }^{99}$ (BECKER et al., 2012).

De acordo com Marlow et al. (2009), os insumos agrícolas totais necessários na produção de uma dieta vegetariana costumam envolver 2,9 vezes menos água, 13 vezes menos fertilizante, 1,4 vezes menos pesticidas e 2,5 vezes menos energia primária.

Segundo Waldman (2011), a pecuária é também o setor que produz a maior parcela de resíduos sólidos gerados: 39\% do lixo produzido mundialmente, seguido da mineração (que corresponde a 38\%), da agricultura (com 19\%), sendo que os resíduos sólidos urbanos correspondem a apenas $2,5 \%$. O que é mais facilmente compreendido se levarmos em conta os grandes fluxos de matéria e energia envolvidos na indústria pecuária.

As discussões possíveis entre vegetarianismo e meio ambiente não se pautam exclusivamente pelos impactos da pecuária ou por supostos benefícios na adoção de DBP para reduzir a demanda por recursos naturais e combater as problemáticas socioambientais. Existem outras temáticas que também podem ser estudadas. É possível explorar, por exemplo,

\footnotetext{
${ }^{98}$ Em proporção por recursos ecológicos.

${ }^{99}$ Uma parcela destes, no entanto, é destinada à alimentação dos animais, apesar de ser contabilizada como recurso agrícola (BECKER et al., 2012).
} 
as possibilidades do assunto dentro da educação ambiental, como é feito pelos trabalhos de Lamim-Guedes (2012), Siqueira (2014) e Ribeiro (2016). Isso, inclusive, leva ao questionamento acerca de se o vegetarianismo ambiental poderia apresentar possibilidades dentro da educação ambiental ou correria o risco de se enquadrar como uma forma de "adestramento ambiental" ${ }^{100}$. Em suma, são muitas possibilidades e justificativas que conectam os dois assuntos.

\footnotetext{
${ }^{100}$ O artigo de Brugger (2009) explora essa discussão, mas com um foco maior em questões como o especismo e antropocentrismo. Para maiores detalhes sobre o conceito de "adestramento ambiental", ver Brugger (1994).
} 


\section{O SISTEMA-CARNE E SUAS EMISSÕES}

Como mostrado pelo capítulo anterior, a discussão da relação entre vegetarianismo e meio ambiente parte, sobretudo, do preceito de que a indústria de produção animal ${ }^{101}$ é uma das mais impactantes em termos ambientais. Dada a centralidade da carne e de seu sistema produtivo nas críticas vegetarianas, a importância de compreender melhor tais objetos de acusação se faz presente. Para conhecer melhor os atores e fatores mais importantes no tema, é necessário, portanto, compreender a produção, o mercado e o próprio consumo de carne.

Abordando estes elementos pela perspectiva mais ampla de um "sistema-carne"102, é possível englobar diversos fatores que tornam possível todo o ciclo pecuário no Brasil, sendo composto não apenas pela produção em si, mas pela demanda, consumo, mercado, paradigmas e crenças; o agronegócio como um todo e sua influência política. A centralidade, deste sistema em questão, na "carne" se dá pela importância do elemento, não apenas como o principal produto da indústria pecuária em termos de quantidade e faturamento (ASSOCIAÇÃO BRASILEIRA DAS INDÚSTRIAS EXPORTADORAS DE CARNES, 2018), mas, por também ser o ponto principal no discurso dos atores que compõem ou que criticam este sistema ${ }^{103}$ (SORDI, 2013).

Nesse sentido, o item 2.1 e seus subitens, detalham algumas das informações básicas sobre os principais elementos que estruturam e fazem possível com que haja a produção e o consumo de carne, especialmente no contexto brasileiro. Estes itens providenciam o necessário para aprofundar a questão central da pesquisa e abordar controvérsias com uma maior amplitude de pontos de vista e conhecimentos sobre este objeto de crítica do vegetarianismo ambiental.

Entretanto, passando para o foco deste trabalho, a questão específica das emissões de GEE, dentro desse âmbito do sistema-carne, são abordadas no item 2.2. Para isto,

\footnotetext{
${ }^{101}$ É necessário ressaltar que a indústria de produção animal não se resume somente a alimentos, tais como carne, laticínios e ovos. Existem muitos outros produtos que são oriundos dos animais e que não estão envolvidos necessariamente com a alimentação humana. Entretanto, a força motriz desta indústria é, essecialmente, a produção de carne, uma vez que a maior parte de seu faturamento se dá nesse sentido, seja no mercado interno ou em exportações (ASSOCIAÇÃO BRASILEIRA DAS INDÚSTRIAS EXPORTADORAS DE CARNES, 2018).

${ }^{102}$ Sordi (2013) utiliza o conceito "sistema-carne" e o tem como objeto de pesquisa no âmbito brasileiro.

${ }^{103}$ No debate em questão, o uso elemento "carne" é recorrente, tanto para os indivíduos e organizações que apoiam, defendem e sustentam a pecuária, quanto nos discursos, argumentações e definições de vegetarianos, veganos e críticos em geral.
} 
naturalmente, a atenção deve se direcionar para o polo da produção e, especificamente, para o conhecimento científico sobre as relações entre a produção animal e as mudanças climáticas.

\subsection{Dimensões e dinâmicas do sistema-carne}

A população humana consiste em cerca de sete bilhões e meio de indivíduos (WORLDOMETERS, 2018) e, todo o ano, especialmente por conta da alimentação, criamos e abatemos um número dez vezes maior de animais terrestres, mais de setenta bilhões, além de uma quantidade ainda maior de animais aquáticos (FOOD AND AGRICULTURE ORGANIZATION OF THE UNITED NATIONS, 2018). O número de animais para esta destinação é tão grande que o gado corresponde a $60 \%$ da biomassa total de mamíferos do planeta, enquanto os seres humanos correspondem a $36 \%$ e animais selvagem somam apenas 4\% (BAR-ON; PHILLIPS; MILO, 2018).

No Brasil, a produção não é menos significativa. Uma das afirmações mais frequentes para expor este cenário é a maior quantidade de cabeças de gado bovino que de pessoas existente no país: 221 milhões (ASSOCIAÇÃO BRASILEIRA DAS INDÚSTRIAS EXPORTADORAS DE CARNES, 2018) e 207 milhões, respectivamente ${ }^{104}$ (INSTITUTO BRASILEIRO DE GEOGRAFIA E ESTATÍSTICA, 2017).

No ano de 2017, o Brasil ocupou o posto de país com maior rebanho bovino do mundo, sendo que a pecuária nacional, como um todo, contribuiu com 6,82\% do PIB (Produto Interno Bruto) do país ${ }^{105}$, movimentou 523 bilhões de reais, criou mais de oito mil empregos. Ao todo, no mesmo ano, a pecuária bovina exportou mais de 407 mil cabeças de gado e produziu 9,7 milhões de Toneladas Equivalentes de Carcaça (TEC). O único país que supera, em quantidade, a produção de carne bovina brasileira é os EUA (ASSOCIAÇÃO BRASILEIRA DAS INDÚSTRIAS EXPORTADORAS DE CARNES, 2018). Apesar do protagonismo da pecuária bovina no cenário nacional, a suinocultura e a avicultura nacionais também possuem um sucesso semelhante (SORDI, 2013).

\footnotetext{
${ }^{104}$ Ambos os dados são médias referentes ao ano de 2017.

105430 bilhões de reais especificamente, o que correspondeu a 31\% do PIB do agronegócio (ASSOCIAÇÃO BRASILEIRA DAS INDÚSTRIAS EXPORTADORAS DE CARNES, 2018).
} 
O Brasil possui três das oito maiores indústrias de carne ${ }^{106}$ do planeta: a JBS S. A., em primeiro lugar, a Brasil Foods (BRF S. A.), em quarto lugar, e a Marfrig Global Foods, ${ }^{107} \mathrm{em}$ oitavo lugar (HEINRICH BÖLL FOUNDATION, 2015). O protagonismo do país em exportações de produtos animais ${ }^{108}$ é uma das consequências da reestruturação na produção nacional, que ocorreu na década de 90, na qual houve uma intensificação nas pautas de exportação em commodities agrícolas e minerais (LAPLANE; SARTI, 2005; LISBOA, 2009).

A liderança do Brasil no mercado internacional de carnes é resultado de uma gama de fatores que asseguraram o crescimento da atividade pecuária (CARVALHO; ZEN, 2017). O aumento do estoque bovino nas últimas décadas, estratégia decisiva para a situação atual, só foi possível devido à expansão das áreas de pasto no Centro-Oeste do país, bem como o desenvolvimentos de sistemas de engorda, o auxílio de técnicas de inseminação artificial, seleção genética dos animais, utilização de novas pastagens forrageiras, dentre outras ações (HEINRICH BÖLL FOUNDATION, 2015).

Além disso, é preciso destacar os grandes investimentos e subsídios feitos no setor. Entre os anos de 2000 e 2011 o Banco Nacional de Desenvolvimento Econômico e Social (BNDES) desembolsou aproximadamente 19,4 bilhões de reais para a pecuária ${ }^{109}$. 30\% deste valor foi referente ao ano de 2008, no qual o banco lançou a política das "campeãs nacionais", onde houve grande apoio financeiro com uma participação acionária nas maiores empresas brasileiras (AMARAL et al., 2012). Destacam-se como beneficiários dessa política a JBSFriboi, a Mafrig Global Foods e a BRF. Os recursos investidos nestes grupos foram utilizados, especialmente, para a compra e aquisição de outras empresas. A Tabela 2Tabela 2 mostra a participação do BNDES no capital de algumas dessas companhias. Tendo em vista a situação, é possível concluir que uma boa parte do sucesso da indústria pecuária brasileira foi propiciada pelo investimento do dinheiro dos contribuintes.

\footnotetext{
${ }^{106}$ Em termos de faturamento em vendas de alimentos no período de 2011 até 2014 (HEINRICH BÖLL FOUNDATION, 2015).

${ }^{107}$ Em 2013 a Mafrig Global Foods vendeu boa parte das suas unidades produtoras de aves e suínos para a JBS (MAMONA, 2015).

${ }^{108}$ A exportação de boi vivos é o exemplo mais significativo neste âmbito (ASSOCIAÇÃO BRASILEIRA DAS INDÚSTRIAS EXPORTADORAS DE CARNES, 2018; BEEF POINT, 2010). Existe a participação importante de outras categorias como, por exemplo, os produtos embutidos e os miúdos, mas estes costumam representar uma parcela menor nas exportações pecuárias (ASSOCIAÇÃO BRASILEIRA DAS INDÚSTRIAS EXPORTADORAS DE CARNES, 2018).

${ }^{109}$ Valor referente a somatória dos investimentos na produção, abate e processamento (AMARAL et al., 2012).
} 
Tabela 2 - Participação do BNDES no capital de empresas relacionadas com a produção animal e em fundos de investimento do agronegócio

\section{Empresa/Fundo de investimento}

JBS S. A.

Marfrig Global Foods S. A.

LBR - Lácteos Brasil S. A.

Ouro Fino Saúde Animal S. A.

Brasil Agronegócio (Fundo de investimento)

\section{Participação do BNDES}

$$
21,32 \%
$$

$33,74 \%$

$30,28 \%$

$12,26 \%$

$20,11 \%$

Fonte: Banco Nacional de Desenvolvimento Social, 2018.

A JBS-Friboi é o caso de maior sucesso e está entre as dez principais empresas internacionais de alimentos e bebidas. A empresa figura como a maior produtora de carne bovina e de frango do planeta, com faturamentos que ultrapassavam até mesmo as maiores gigantes da indústria alimentícia, como a Unilever, Cargill, Tyson Foods e a Danone, tendo uma imensa capacidade de produção e uma exportação que alcança 150 países $^{110}$ (HEINRICH BÖLL FOUNDATION, 2015).

Apesar do sucesso da pecuária brasileira como maior exportadora mundial, enviando carne bovina para diversos locais do planeta, em especial, Hong Kong, China, Egito, Rússia, Irã e UE, a exportação corresponde a apenas $20 \%$ da produção nacional de carne. A maior parte, na verdade, é destinada ao mercado interno - cerca de 80\% (ASSOCIAÇÃO BRASILEIRA DAS INDÚSTRIAS EXPORTADORAS DE CARNES, 2018). O consumo médio pelo brasileiro aumentou significativamente até o ano de 2015, por conta do crescimento econômico ocorrido no país a partir de 2003, sendo que a carne bovina e o leite constituíram, conjuntamente, $18,7 \%$ de sua dieta. O aumento no consumo de produtos de origem animal nos países do BRICS ${ }^{111}$ também se deu por conta do mesmo fator: as classes médias emergentes nestes países trouxeram consigo uma nova demanda por estes alimentos (ESTEVE, 2017; HEINRICH BÖLL FOUNDATION, 2015).

\footnotetext{
${ }^{110}$ Apesar dos abalos sofridos com a operação "Carne Fraca" (vide item 2.1.2) e o escândalo político envolvendo a delação premiada dos irmãos Batista, em 2017 (para mais detalhes ver Ruediger (2017)), a JBS dobrou seu lucro no mesmo ano (CUNHA, 2018) e, em 2018, ainda figurava como a líder mundial na produção de carne bovina (PORTAL G1, 2018b).

111 Acrônimo utilizado inicialmente para se referir ao grupo BRIC: Brasil, Rússia, Índia e China. Com a integração formal da África do Sul ao grupo em 2011, a sigla foi mudada para BRICS. Estes países compõem cerca de $40 \%$ da população mundial (JONY; RIBEIRO; FRACALOSSI DE MORAES, 2012).
} 
Como alguns estudos sugerem (DELGADO, 2003; HUANG; BOUIS, 1996; VRANKEN et al., 2014), o aumento na renda de populações com menor poder aquisitivo traz consigo o crescimento no consumo de carne em diversos locais do mundo, incluindo o Brasil (CARVALHO, 2007; KIRINUS et al., 2013; SCHLINDWEIN; KASSOUF, 2006). Além disso, especialmente nos países "em desenvolvimento", as noções de progresso e de modernidade tem sido fortemente associadas a este alimento. Na Índia, o país com a maior tradição e população vegetariana do planeta, uma postura e identidade "não vegetariana" simboliza, em alguns setores, um elevado "status social", uma vez que, nestes casos, o "comer carne" estaria relacionado ao suposto progresso material de um modo de vida mais ocidentalizado (ESTEVE, 2017).

$\mathrm{Na}$ América Latina também é possível perceber que não apenas o consumo de alimentos de origem animal tem aumentado nos últimos 20 anos, mas que a pecuária está ligada aos modos de vida de uma forma ampla e diversa. Desde os rituais sociais mais íntimos, como o churrasco com a família e amigos, até os estereótipos oferecidos aos turistas, como o do vaqueiro, passando pelo desenvolvimento de economias familiares e definições de políticas internacionais. Diversos aspectos da sociedade, dentro da maior região de expansão do agronegócio do planeta, a América Latina, estão intimamente associados ou estruturados nos animais e naquilo que os rodeia (HEINRICH BÖLL FOUNDATION, 2015). O sistemacarne que estamos vivendo e observando vai, portanto, muito além da simples questão de se produzir e consumir carne (SORDI, 2013).

A produção, que supre as crescentes demandas da população brasileira, segue lógicas industriais. Por exemplo, as aves que são encontradas nos supermercados do país não são mais de galinhas caipiras que andam livremente por sítios e se alimentam de grãos remanescentes de colheitas: tratam-se de animais com ciclos de vida cada vez mais reduzidos e otimizados, confinados em pequenos espaços (de 20 a $50 \mathrm{~cm}$ ), nutridos com soja e recebendo grandes quantidades de antibióticos (DIAS, 2009; HEINRICH BÖLL FOUNDATION, 2015).

No caso da produção de bovinos, em modelos mais tradicionais, os animais pastavam ao ar livre e eram criados em médios e pequenos rebanhos, sendo que estes, geralmente, eram abatidos em locais próximos. A carne produzida no processo era consumida localmente, em taxas menores do que as atuais. Tal modelo está praticamente extinto atualmente (SORDI, 2013). 
O advento da indústria pecuária propiciou não apenas uma quantidade muito maior de animais sendo criados, abatidos e processados, mas também possibilitou o distanciamento progressivo entre o local onde o animal é criado e onde ele será abatido, bem como do consumidor final (DIAS, 2009). A pecuária bovina norte americana é um exemplo dessa otimização. Nos sistemas de criação intensivos do país, onde os animais são alimentados com ração e se desenvolvem confinados, pode alcançar-se uma capacidade de abater bois com uma média de $700 \mathrm{~kg}$, em um tempo de apenas 24 meses (SORDI, 2013).

$\mathrm{O}$ processo e as mudanças que propiciaram o aumento significativo na produção e consumo de carne e produtos de origem animal, de modo geral, tem sido chamado de "revolução pecuária" (ALLIEVI; VINNARI; LUUKKANEN, 2015; DELGADO et al., 1999). Seguindo um padrão paralelo à "revolução verde", especialmente no seu aspecto produtivista, o novo sistema pecuário estabelecido modificou definitivamente a dieta de grande parte a população e promoveu a concentração empresarial no setor (ESTEVE, 2017). Apesar de propiciar o aumento significativo da produção e produtividade agrícola, a "revolução verde" não cumpriu completamente com seu suposto objetivo de erradicação da fome ${ }^{112}$ e, além disso, aumentou a concentração fundiária, causou dependência dos agricultores aos OGMs (Organismos Geneticamente Modificados) e aos insumos industriais (como os agrotóxicos), prejudicou seriamente a cultura de pequenos produtores e propiciou o advento de grande parte dos principais problemas socioambientais modernos (MAZOYER; ROUDART, 2010). Analogamente, a "revolução pecuária" também permitiu o aumento significativo da produtividade $^{113}$ (ESTEVE, 2017), mas acabou gerando e agravando diversos impactos ambientais e sociais e, com isso, trouxe consigo riscos à segurança alimentar como um todo, gerando críticas e divergências na abordagem do assunto (MICHELINI; LAHSEN, 2016).

\subsubsection{Riscos, custos e segurança alimentar}

O aumento da eficiência e velocidade na produção animal, por parte das grandes indústrias, acabou também por concentrar o poder deste mercado em poucas empresas e

\footnotetext{
112 Apesar de contribuir positivamente para a redução da fome, há de se levar em conta que prdutividade e quantidade de alimentos não são os únicos fatores em questão, mas, há de se considerar desigualdade social, pobreza, desperdício, dificuldade ao acesso dos alimentos, dentre outros.

${ }^{113}$ É preciso ressaltar que, ao contrário da "revolução verde", não foram encontrados indícios de que a "revolução pecuária" tenha se promovido com um discurso de combate a fome.
} 
grupos. Além disso, os processos produtivos, tais como o abate, vêm se tornando cada vez mais centralizados em todo o mundo. Ocorreu uma transição generalizada de uma pecuária camponesa, diversificada, local, familiar e de capacidade produtiva limitada, para modelos monopólicos, corporativistas, intensificados, com capacidade de alcançar consumidores distantes. Por um lado, isso trouxe uma capacidade produtiva massiva, o atendimento de demandas elevadas, uma maior capacidade para a exportação ${ }^{114}$, a concentração dos fluxos econômicos e atraiu investimentos significativos; por outro lado, gerou grandes impactos socioambientais, aumentou significativamente as vulnerabilidades do sistema produtivo alimentar, inerentes ao seu crescimento abrupto, e acabou prejudicando e ameaçando a existência dos pequenos produtores, que não possuem capacidade para competir com tais sistemas (ESTEVE, 2017).

Dentre os exemplos de tais vulnerabilidades, que emergem com o rápido crescimento do setor e com suas novas lógicas produtivas, é possível citar o alerta emitido pela Associação Brasileira de Proteína Animal (ABPA), durante a greve de caminhoneiros do Brasil em $2018^{115}$. Segundo o comunicado da ABPA, 1 bilhão de aves e 20 milhões de suínos poderiam morrer por conta da falta de ração na ocasião (ASSOCIAÇÃO BRASILEIRA DE PROTEÍNA ANIMAL, 2018), o que expõe um exemplo da fragilidade desta lógica produtiva que envolve uma grande escala e velocidade. Além disso, é possível citar os problemas de saúde ligados à resistência a antibióticos, citados no item 2.1.4. Em ambientes intensificados, os patógenos se propagam com maior rapidez ${ }^{116}$ e o desenvolvimento de bactérias resistentes é acelerado $^{117}$. De modo geral, manejar volumes tão grandes de animais e de alimentos com garantias de segurança tem sido um desafio ainda maior, levando em conta as deficiências no monitoramento e rastreamento existentes na indústria alimentar. Por conta das diversas vulnerabilidades inerentes à produção animal em larga escala, seguradoras e suas avaliações de risco também estão se tornando parte integrantes do processo industrial (HEINRICH BÖLL FOUNDATION, 2015).

\footnotetext{
${ }^{114}$ Ainda assim, é preciso ressaltar que apenas cerca de $10 \%$ da produção mundial de carne é destinada para a exportação, a maior parte abastece os mercados internos (HEINRICH BÖLL FOUNDATION, 2015).

${ }^{115}$ Paralização nacional de caminhoneiros autônomos no Brasil, devido às oscilações no preço dos combustíveis. Consequentemente, o transporte de ração, insumo essencial para criadores de animais intesivos, foi gravemente prejudicado.

${ }^{116} \mathrm{O}$ que não se aplica à pecuária bovina nacional, uma vez que a maior parte dela é realizada de forma extensiva, não havendo tanta necessidade do uso de antibióticos.

${ }^{117}$ Como é o caso do surgimento da Influenza Aviária A (H5N1), conhecida como "gripe aviária" detectada pela primeira vez no sul da China, em granjas de gansos (HEINRICH BÖLL FOUNDATION, 2015).
} 
Se levarmos em conta todo esse sistema e seus riscos, especialmente aqueles relacionados com as problemáticas socioambientais inerentes ao sistema pecuário atual ${ }^{118}$, é pertinente trazer à tona a discussão de segurança alimentar e nutricional. Existem diversos pontos que podem ser discutidos dentro deste âmbito, tais como a qualidade e sanidade dos alimentos, hábitos e cultura alimentares, além da sustentabilidade dos sistemas alimentares (MALUF; MENEZES, 2004). Além das ameaças diretas à biodiversidade como um todo (MACHOVINA; FEELEY; RIPPLE, 2015; NETHERLANDS ENVIRONMENTAL ASSESSMENT AGENCY, 2010), a crescente perda da diversidade alimentar está relacionada diretamente com o setor pecuário ${ }^{119}$ (ESTEVE, 2017; FOOD AND AGRICULTURE ORGANIZATION OF THE UNITED NATIONS, 2006). De acordo com a Declaração de Interlaken para os recursos genéticos:

\begin{abstract}
A erosão e a perda contínuas de recursos genéticos, animais para a alimentação e a agricultura comprometeriam os esforços realizados para alcançar a segurança alimentar, melhorar o estado nutricional humano e potencializar o desenvolvimento rural (ORGANIZAÇÃO DAS NAÇÕES UNIDAS PARA AGRICULTURA E ALIMENTAÇÃO, 2010, p. 1).
\end{abstract}

De acordo com o “Atlas da Carne”, produzido pela Heinrich Boll Foundation:

\begin{abstract}
A baixa diversidade genética das raças comerciais aumenta a sua vulnerabilidade a pragas e doenças, assim como representa riscos no longo prazo para a segurança alimentar, ao excluir opções para responder aos desafios ambientais, às condições de mercado e às necessidades sociais do futuro: aspectos que são imprevisíveis. Diante das mudanças climáticas, a perda da diversidade genética dos animais ameaça a sustentabilidade no longo prazo não só das comunidades de pastores como dos sistemas pecuários industriais (HEINRICH BÖLL FOUNDATION, 2015, p. 37) .
\end{abstract}

Um estudo de Michielini e Lahsen (2016) explora as implicações da pecuária brasileira na segurança alimentar. $\mathrm{O}$ trabalho apresenta uma interessante situação paradoxal no cenário do agronegócio Brasileiro:

enquanto a literatura científica aponta cada vez mais a necessidade de reduzir a produção e o consumo de carne para fortalecer a segurança alimentar em longo prazo, os entrevistados apresentam a produção pecuária como essencial para garantir

\footnotetext{
118 Tais como os impactos ambientais da indústria de produção animal, citados no item 2.2.

${ }^{119}$ Estima-se que, nos últimos 100 anos, cerca de $75 \%$ da diversidade agrícola tenha desaparecido (ESTEVE, 2017).
} 
a segurança alimentar em níveis nacional e mundial (MICHELINI; LAHSEN, 2016, p. 112).

A proliferação de riscos, vulnerabilidades e externalidades inerentes aumentam paralelamente à complexidade e velocidade das cadeias produtivas e fluxos de matéria e energia do sistema-carne. Quando ocorre a dramatização pública (BECK, 1992) de tais riscos, também são multiplicadas as narrativas conflitantes e os pontos de vista divergentes sobre o próprio sistema produtivo em questão (SORDI, 2013).

Há, por um lado, estudos acadêmicos que apontam riscos, em diversos aspectos, trazidos pelas altas taxas de produção e consumo de carne (CARREIRA; RE'EM; TARIN, 2015; FOOD AND AGRICULTURE ORGANIZATION OF THE UNITED NATIONS, 2006; MATURANA, 2015; MICHELINI; LAHSEN, 2016); por outro lado, o suprimento dessa demanda e o aumento da produtividade por parte da pecuária é apontado por representantes da indústria e pela mídia como um fator essencial para a manutenção da segurança alimentar (MICHELINI; LAHSEN, 2016) ${ }^{120}$.

Paralelamente, é necessário destacar que há uma divergência nos enfoques dados ao próprio conceito de segurança alimentar dentro de diferentes contextos. A UE, por exemplo, adota uma perspectiva mais baseada no "princípio da precaução"121, enquanto, nos EUA, as tomadas de decisões se baseiam em avaliações de risco e de custo-benefício (HEINRICH BÖLL FOUNDATION, 2015).

Os problemas relacionados às condições de trabalho também precisam ser destacados. A disputa por preços mais competitivos é refletido nos desrespeitos a leis trabalhistas e em altos índices de acidentes, lesões e problemas psicológicos nos empregados ${ }^{122}$ de abatedouros e frigoríficos ${ }^{123}$ (DIAS, 2009; ONG REPÓRTER BRASIL, 2013; SORDI, 2013). Em suma, o sistema-carne possui uma das cadeias produtivas que mais gera riscos aos seus

\footnotetext{
120 Além dos exemplos citados por Michelini e Lahsen (2016), é possível também observar esse discurso na mídia, como o caso dos artigos de Ometto (2018) e Hill (2007).

${ }^{121}$ De acordo com Goldim (2002), o princípio da precaução trata-se da "garantia contra os riscos potenciais que, de acordo com o estado atual do conhecimento, não podem ser ainda identificados. Este Princípio afirma que a ausência da certeza científica formal e a existência de um risco de um dano sério ou irreversível requer a implementação de medidas que possam prever este dano". Para mais detalhes sobre o princípio da precaução ver Santos e Beleza (2014).

122 O documentário “Carne e Osso" (CAVECHINI; BARROS, 2011), lançado em 2011, expõe a situação precária de trabalho em diversos frigoríficos do Brasil.

123 É importante ressaltar, no entanto, a importância da introdução de abatedouros públicos ou privados, especialmente em regiões mais pobres, como uma ação essencial para a promoção da higiene e segurança no processamento dos animais (HEINRICH BÖLL FOUNDATION, 2015).
} 
trabalhadores $^{124}$ (MINISTÉRIO DA PREVIDÊNCIA SOCIAL; MINISTÉRIO DO TRABALHO E EMPREGO, 2009; SORDI, 2013).

A pecuária também costuma liderar flagrantes de trabalhos análogos à escravidão no campo. Segundo dados da "lista suja do trabalho escravo", produzidos pela Divisão de Fiscalização para Erradicação do Trabalho Escravo (DETRAE), do Ministério do Trabalho e Emprego (TEM), o maior número de trabalhadores resgatados nessas condições em contexto rural vinham do setor pecuário (CAMPELO, 2017; LOCATELLI, 2018; LYRA, 2012). Além disso, segundo dados do Atlas do trabalho escravo no Brasil, o aumento no rebanho bovino brasileiro coincide espacialmente com as áreas onde mais ocorre a libertação e resgate de trabalhadores em condição análoga a de escravo (THÉRY et al., 2012).

Apesar dos problemas trabalhistas do setor, é preciso ressaltar que a cadeia da carne bovina brasileira mantém, aproximadamente, 7 milhões de empregos (INSTITUTO DE MANEJO E CERTIFI CAÇÃO FLORESTAL E AGRÍCOLA, 2015), além do fato de que a economia de uma parte significativa dos municípios brasileiros se baseia na agropecuária (INSTITUTO BRASILEIRO DE GEOGRAFIA E ESTATÍSTICA, 2015). Em pequena escala, a criação de gado pode, inclusive, reduzir a pobreza, contribuir para a igualdade de gênero e possibilitar uma dieta saudável (HEINRICH BÖLL FOUNDATION, 2015).

Ainda que levemos em conta a significativa contribuição para o PIB e empregos no Brasil, além do evidente sucesso econômico das empresas no setor, algumas possíveis consequências negativas, advindas do atual poder produtivo pecuário centralizado em poucas empresas, podem ser elencadas (HEINRICH BÖLL FOUNDATION, 2015):

- Apropriação das margens de lucro dos pequenos criadores pelos grandes frigoríficos;

- Concentração do mercado e formação de oligopólios, bem como a consequente possibilidade de elevação do preço para os consumidores finais;

- Falta de garantias de que os investimentos e capital exportados neste $\operatorname{setor}^{125}$ vão, de alguma forma, retornar ao Brasil;

- Utilização de recursos federais, que deveriam ser destinados para o desenvolvimento social nacional, em atividades que geram empregos em outros países;

\footnotetext{
${ }^{124}$ Segundo o Ministério da Previdência Social e o Ministério do Trabalho e Emprego, as atividades de trabalho deste setor possuem riscos, em média, três vezes maiores do que outras atividades (MINISTÉRIO DA PREVIDÊNCIA SOCIAL; MINISTÉRIO DO TRABALHO E EMPREGO, 2009)

${ }^{125}$ Isso se baseia especialmente na compra de frigoríficos em outros países. Prática que foi realizada, por exemplo, pela JBS-Friboi, com o apoio de investimentos do BNDES, como uma forma estratégica de acesso a mercados estrangeiros pela empresa. (HEINRICH BÖLL FOUNDATION, 2015).
} 
- O desbalanço entre uma economia baseada na exportação de commodities e a dependência da importação de produtos com maior grau de tecnologia, reforçado por um banco que deveria fomentar o desenvolvimento.

- O faturamento, obtido com os recursos dos contribuintes, acaba se concentrando nas mãos de poucas empresas e de poucos acionistas, sem contar as externalidades ambientais que acabam recaindo sobre a população e gerando mais custos para o próprio governo $^{126}$.

No que diz respeito aos abatedouros e frigoríficos, as críticas direcionadas à indústria animal têm-se intensificado e escândalos envolvendo o setor geram pressão e exigências às empresas, influenciando na redução do consumo em países industrializados (ESTEVE, 2017). Um exemplo disso foi a operação "Carne Fraca", conduzida pela Polícia Federal do Brasil, que investigou a adulteração e problemas envolvendo higiene na produção das maiores empresas nacionais, tais como a JBS e a BRF (BRITISH BROADCASTING CORPORATION NEWS, 2017; SILVA, 2016). A operação gerou uma queda na exportação brasileira (DEPARTAMENTO INTERSINDICAL DE ESTATÍSTICA E ESTUDOS SOCIOECONÔMICOS, 2017) e afetou a confiança da comunidade internacional no setor, com diversos países declarando embargos e restrições (PINTO, 2017). Os requisitos e envolvidos na exportação também são um elemento importante, uma vez que diversos países que importam carne do Brasil estão entre os mais exigentes com relação aos parâmetros fitossanitários, bem estar animal, rotulagem e outros critérios (DEPARTAMENTO INTERSINDICAL DE ESTATÍSTICA E ESTUDOS SOCIOECONÔMICOS, 2017). A adequação a esses critérios acaba por elevar o custo de produção (MIRANDA, 2001).

Aprofundando na questão, o preço de comercialização da carne não reflete no seu verdadeiro custo. Para calcular seu real valor, deve-se levar em conta não apenas o preço pago pelo consumidor final, mas aquele pago pelo contribuinte ${ }^{127}$ e pela natureza (SCHUCK; RIBEIRO, 2015). No que tange o aspecto da natureza, foco deste trabalho, é possível dizer que a pecuária bovina brasileira representa um custo inigualável, mesmo levando em conta outras atividades que não estão relacionadas com produção de alimentos diretamente, mas que costumam figura como as mais impactantes em termos ambientais. Na Tabela 3 são

\footnotetext{
${ }^{126}$ Vide a disparidade econômica entre receita e impactos ambientais na pecuária bovina nacional, citada na Tabela 3.

${ }^{127}$ Como é o exemplo do investimento feito pelo BNDES em favor de grandes empresas pecuárias brasileiras, já mencionado anteriormente.
} 
apresentados dados de um relatório que contabiliza o verdadeiro custo ambiental envolvido em diversas atividades econômicas no Brasil. Nele, é possível perceber a disparidade da pecuária bovina, mesmo frente a refinamento de petróleo e mineração.

Tabela 3 - Custo para o capital natural em diferentes atividades econômicas no Brasil

\section{Atividade econômica}

Pecuária bovina

Refinamento e mistura de óleos e gorduras

Aquicultura

Abate e processamento de animais

Agricultura de algodão

Agricultura de soja

Agricultura de cana

Fabricação de cimento

Fabricação de fertilizante

Fabricação de celulose

Exploração madeireira

Mineração de minério de ferro

Transporte aéreo
Custo ambiental em milhões reais (para cada 1 milhão de reais em receita gerada)

Fonte: Adaptado de Carreira; Re'em; Tarin, 2015.

É possível afirmar que a produção de carne em questão, em lógicas industrializadas brasileiras, se sustenta através do dano ambiental que causa, não apenas de forma direta, com os pastos e os criadouros, mas também de forma indireta, considerando a produção de forragem. Em síntese, se o preço final da carne refletisse todos estes custos ocultos, tal pecuária seria uma atividade economicamente inviável. Estes custos não são pagos pelas indústrias, mas, recaem sobre a população na forma de externalidades diversas (GREIF, 2002).

É necessário ressaltar que os custos ocultos, no entanto, não são exclusivos à pecuária, mas estão em diversos outros produtos e atividades econômicas, tal como é possível observar na Tabela 3. O ponto central, no caso, é o elevado valor destes custos na indústria pecuária brasileira.

Por fim, também há questão do tratamento para com os animais nas diversas etapas produtivas na cadeia da carne, o que acaba gerando um grande debate devido às frequentes 
violações ao bem-estar animal cometidas na indústria ${ }^{128}$. As organizações, autores e movimentos com posturas abolicionistas ${ }^{129}$, por sua vez, vão além e criticam a própria existência de toda a indústria, acusam a mesma de tratar os animais como produto e se opõem à ideia da necessidade do consumo de alimentos de origem animal, colocando, muitas vezes, o vegetarianismo e o veganismo como alternativas a esse sistema dito "cruel" e "desnecessário" (PHELPS, 2007).

Por conta deste e diversos outros motivos ${ }^{130}$, os principais atores brasileiros interessados na manutenção e crescimento da pecuária, tais como a ABIEC (Associação Brasileira das Indústrias Exportadoras de Carne), tem reconhecido, abertamente, que é necessário defender o valor social da carne e do gado como unidade de valor. Nessa perspectiva, além de defensores dos direitos dos animais, organizações vegetarianas e veganas, ativistas e ambientalistas, a parcela da comunidade científica que critica aspectos da produção animal também é colocada como um obstáculo. Campanhas e ações que, por um lado, contrabalanceiam as alegações de risco feitas pelos críticos à carne e, por outro, reativam a importância da produção animal como parte essencial da economia e cultura brasileira, tem sido desenvolvidas e fomentadas, visando alcançar e influenciar diversas $\operatorname{esferas}^{131}$ (SORDI, 2013). As grandes empresas pecuárias têm lançado mão de diferentes ações para contrapor todo o movimento em prol da redução do consumo de carne, no qual não apenas o vegetarianismo, mas diversas outras formas de ativismo alimentar se inserem.

Este cenário integra uma parte do que Legoy e Sordi (2012) se referem como as "guerras da carne", onde defensores e críticos da carne geram intensas discussões e $\operatorname{conflitos}^{132}$. É preciso ressaltar, dentro deste âmbito, a importância que a legitimidade científica possui. Dentro da estrutura fluidificada das disputas envolvendo a situação futura e atual da carne, grande parte das argumentações são marcadas pela invocação de informações e dados de natureza acadêmica. Seja para decidir se a carne é um alimento saudável ou não, mensurar seu valor positivo ou negativo em aspectos econômicos, ou ainda nos dados que

\footnotetext{
${ }^{128}$ Diz respeito especialmente ao sofrimento desnecessário infringido aos animais no processo produtivo. Diversos exemplos, tais como crueldade, violência desnecessária, transporte em condições inadequadas, dentre outros, podem ser encontrados no trabalho de Singer (SINGER, 2004).

${ }^{129}$ Descritos e exemplificados no item 2.1.3.

${ }^{130}$ Tais como a discussão de impactos ambientais da pecuária, abordada no item 2.2 , ou as denúncias de trabalho análogo à condição de escravo, citadas nos parágrafos anteriores.

${ }^{131}$ Alguns exemplos podem ser encontrados no trabalho de Sordi (2013).

${ }^{132}$ Para mais detalhes sobre os conflitos gerados pela questão do vegetarianismo ver Abonízio (2016)
} 
correlacionam a indústria pecuária com os problemas socioambientais modernos, é possível identificar uma presente busca pela legitimidade científica dos discursos. Tal fenômeno se relaciona diretamente com a natureza controversa do debate a respeito do vegetarianismo, uma vez que o tema representa parte integrante das disputas nas "guerras da carne" (SORDI, 2013).

Figura 3 - Produtos feitos a partir de bovinos

\section{Produtos feitos a partir de bovinos}

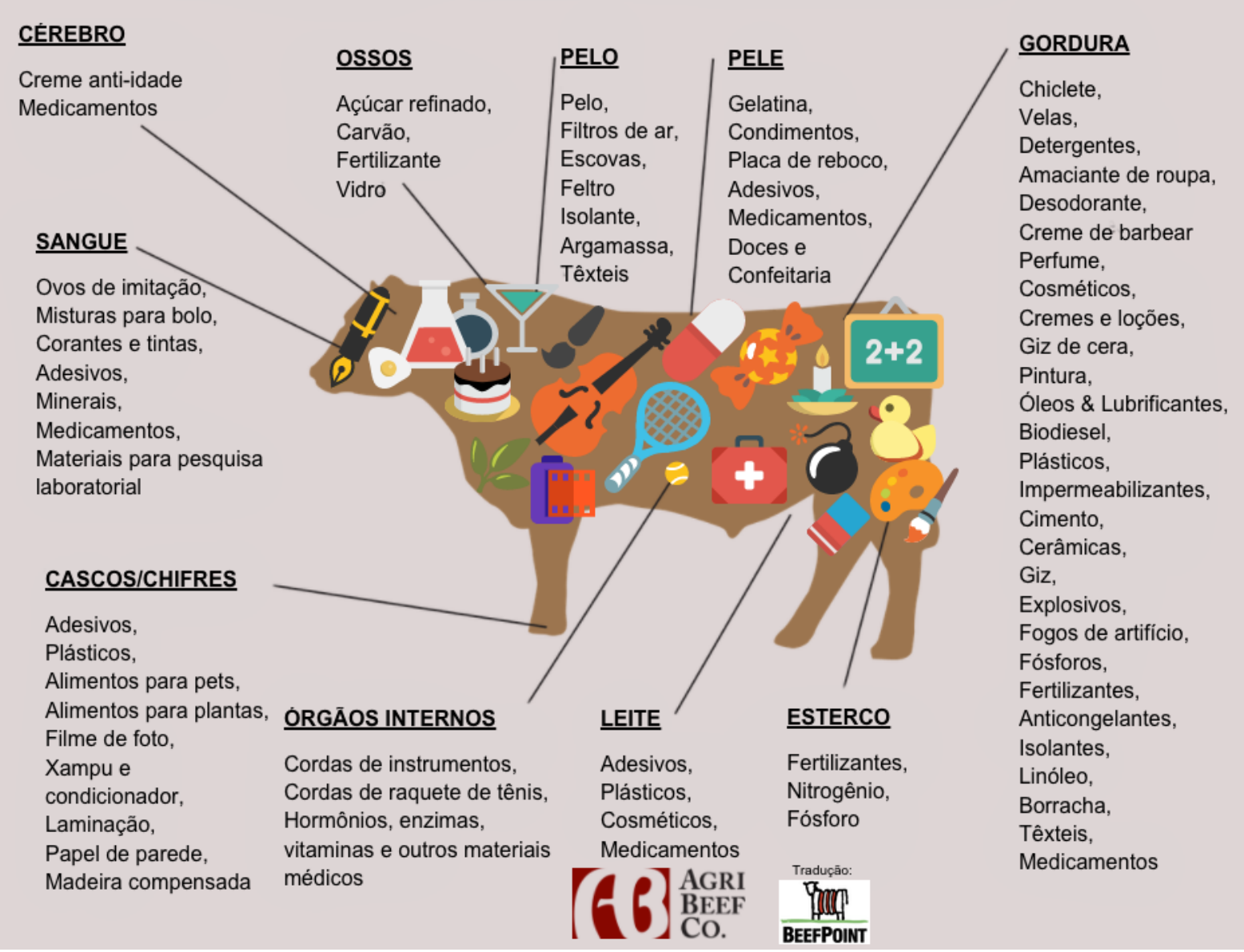

Fonte: Beef Point, 2016.

A defesa do gado, como unidade de valor, não está exclusivamente ligada a alimentação. A indústria do couro, por exemplo, supre a produção de calçados, vestuário de modo geral, móveis, a cadeia automotiva, dentre outros setores, movimentando bilhões de reais (AGÊNCIA BRASILEIRA DE DESENVOLVIMENTO INDUSTRIAL, 2011). Outras matérias, produzidas direta e indiretamente a partir do boi, agregam valor à indústria animal, 
tais como gelatina, sebo, chifres, cascos, bílis, renina para produzir "coalho", substâncias para remédios, adubo, dentre outras. Resumidamente, quase todas as partes dos animais podem ser aproveitadas de alguma forma e suprem diversos outros setores. A Figura 3 exemplifica essa situação:

\subsubsection{Tendências no consumo e produção}

Não há como desconectar o polo da produção, como modalidade de interação entre humanos e animais, do polo do consumo, como prática alimentar cultural e socialmente mediada. Tampouco é possível excluir os consumidores como partes integrantes do sistemacarne (SORDI, 2013). Faz-se necessário, portanto, compreender como este importante ator se insere na discussão e sustenta essa cadeia e suas tendências, bem como a produção acompanha e influencia tudo isso.

Do mesmo modo que maior parte da produção de carne se transformou significativamente, o consumo acompanhou e retroalimentou, tal mudança. Atualmente, o consumidor pode encontrar uma variedade de cortes com aparência fresca e cor viva, apesar dos dias de armazenamento, em mostruários refrigerados, seja em supermercados próximos ou nos próprios açougues, tendência que se faz presente, inclusive, em países de economia emergente. Além do aumento do poder aquisitivo de classes médias, outros fatores foram decisivos para isso. Em diversos locais do mundo, incluindo o Brasil, o aumento nas taxas de consumo de carne está intimamente relacionado com a rápida expansão das grandes cadeias de supermercado. Elas trouxeram novos métodos e padronizações, pois os modelos tracionais de produção e distribuição da carne não eram suficientes para suprir as demandas. Devido a todas as mudanças ocorridas na chamada "revolução pecuária", o consumo de carne, que há 20 ou 30 anos era um privilégio em diversos locais do planeta, hoje tornou-se um hábito (ESTEVE, 2017; HEINRICH BÖLL FOUNDATION, 2015).

Em suma, o crescimento demográfico e o processo de urbanização também contribuíram para mudança nos padrões consumo nos BRICS, mas o fator de maior peso nessa equação está relacionado à ascensão das classes médias e ao aumento do poder econômico dos consumidores. Apenas entre os anos de 2003 e 2012, o consumo de carne mundial cresceu 6,3\% (ESTEVE, 2017) e projeções indicam que, se as tendências não 
mudarem, a demanda total por carne no planeta pode chegar a crescer até $73 \%$ até $2050^{133}$ (FOOD AND AGRICULTURE ORGANIZATION OF THE UNITED NATIONS, 2011) e a demanda global por produtos de origem animal, como um todo, irá dobrar até 2050 nas nações “em desenvolvimento"134 (ROJAS-DOWNING et al., 2017).

Em certos locais, os panoramas são ainda mais consideráveis nesse sentido, como é o caso da demanda por carne de aves no sul da Ásia, onde estima-se um aumento de setes vezes até 2050. A futura preferência por frango no lugar de outros tipos de carne se deve, em boa parte, pelo preço. Além de serem as aves domesticadas mais disseminadas até hoje (HARARI, 2017), tratam-se de um dos tipos de gado ${ }^{135}$ mais eficientes em termos de conversão de alimentos. A carne de porco também possui uma lógica similar ao frango: ambos os animais costumam ser criados em sistemas de confinamento, seu custo acaba sendo reduzido e sua produção é uma interessante fonte para suprir a demanda por carne mais barata, especialmente levando em conta o contexto dos países em desenvolvimento ${ }^{136}$ (HEINRICH BÖLL FOUNDATION, 2015).

De modo geral, o setor da pecuária (que já é grande) e o consumo de carne mundial crescem em um ritmo acelerado, devido ao aumento populacional e, sobretudo, às mudanças nos padrões de consumo (HERRERO et al., 2015). Concomitantemente a todo esse crescimento, há uma tendência antagônica: um número cada vez maior de pessoas está comendo menos carne ou, até mesmo, deixando de comê-la. Movimentos de consumo político, ideologias alimentares e motivações de diversas naturezas tem levado muitas pessoas a repensar a alimentação de origem animal. No entanto, ainda é preciso ressaltar que comer muita ou pouca carne - ou ainda se tornar vegetariano -, não é uma questão de opção para muitos. Diversas pessoas não possuem um amplo espectro de escolhas no que diz respeito à alimentação, seja por limitações econômicas ou por indisponibilidade dos alimentos,

\footnotetext{
${ }^{133}$ Considerando como ponto inicial a demanda total por carne referente ao ano de 2010.

134 É preciso levar em conta que, com a recente crise econômica e política brasileira, deflagrada a partir 2014, tanto o consumo interno quanto a exportação de carne sofreram quedas, como mostra Lima (2018). Logo, dadas as instabilidades e incertezas envolvidas no atual mercado brasileiro, as projeções para demandas futuras podem ser diferentes.

135 Apesar de não ser muito comum, o termo "gado" pode ser utilizado para criação de aves domésticas, uma vez que a palavra se refere à um "conjunto de animais" (DICIO, 2018). O termo "gado de bico" também já foi empregado popularmente, como mostra o trabalho de Maduro (2007).

${ }^{136}$ As carnes de porco, frango e boi, juntas, correspondem a $88 \%$ de toda a carne desossada consumida no planeta (FOOD AND AGRICULTURE ORGANIZATION OF THE UNITED NATIONS, 2018).
} 
especialmente em contextos de crise (DREWNOWSKI; SPECTER, 2004; ESTEVE, 2017; JABS; DEVINE, 2006).

Apesar do crescimento global do consumo da demanda por carne ter ocorrido especialmente nos países "em desenvolvimento", na verdade, é nos países industrializados e “desenvolvidos" que o consumo é maior. Austrália, EUA, Israel, Canadá e diversos países da UE possuem as maiores taxas do planeta (FOOD AND AGRICULTURE ORGANIZATION OF THE UNITED NATIONS, 2013c), ainda que estas tenham alcançado níveis máximos e se estagnado na maior parte das vezes (VRANKEN et al., 2014). Há evidências que indicam que, em um primeiro momento, o aumento da renda da população eleva o consumo de carne até certo patamar e, após isso, aconteceria o que Vranken et al. (2014) nomeia como uma "segunda transição nutricional”, na qual ocorreria uma gradual substituição para proteínas de origem vegetal.

Nos EUA, por exemplo, ocorreu uma queda de $9 \%$ no consumo de carne entre os anos de 2007 e 2012 (WILLET, 2014). Seja pelas desconfianças com relação à qualidade da carne e do sistema produtivo, pelo bem-estar dos animais, por motivações de caráter socioambiental ou por uma crescente rejeição visando certos critérios de saúde, as tendências destes consumidores tem preocupado a indústria pecuária (MARTINKO, 2018). Na mídia, publicações relacionadas à nutrição e estilo de vida "fitness" enfatizam a importância de dietas com baixa ingestão de carne, associando isto a um estilo de vida saudável e moderno (HEINRICH BÖLL FOUNDATION, 2015).

Os consumidores, especialmente aqueles com alto poder aquisitivo e maior engajamento em questões ambientais e sociais, estão cada vez mais preocupados em obter carne que seja produzida de maneira ética, sustentável e com qualidade (FONT-I-FURNOLS; GUERRERO, 2014). Em resposta a isso, algumas companhias lançaram mão de estratégias de marketing com rotulagens próprias, inserindo selos e atestados de qualidade em seus produtos, visando, assim, convencer o consumidor final da existência dos padrões desejados em suas cadeias produtivas. De modo geral, tais estratégias, mais flexíveis, simples, com baixas garantias e menor necessidade de mudanças, são muito mais utilizadas pelas empresas do que adoção de sistemas de certificação por terceiros (RIBEIRO, 2008). Um exemplo interessante de sistema de certificação é o da "carne orgânica", que possui critérios como a ausência de OGMs e de antibióticos na criação dos animais, a origem local dos animais e da ração, dentre outros fatores (CARRIJO; ROCHA, 2002). Ainda que seja uma forma 
interessante de regular a produção e informar diversos atributos para o consumidor, apenas $2 \%$ da carne comercializada em países industrializados é produzida dentro de tais parâmetros (HEINRICH BÖLL FOUNDATION, 2015).

Devido a todas as instabilidades e tendências de descrecimento do consumo de produtos de origem animal em países industrializados, grandes empresas do próprio setor pecuário e da indústria alimentícia de modo geral também tem dedicado investimentos ao mercado de proteínas alternativas (NUTRIKÉO, 2015). É possível citar o exemplo da empresa americana Tyson Foods, uma das maiores produtoras de carne do planeta, que comprou uma participação na Memphis Meats, startup que produz carne em laboratório ${ }^{137}$ (SORVINO, 2018), ou ainda o caso da Maple Leaf Foods, grande processadora de carne canadense, que adquiriu a Lightlife Foods, uma das principais fabricantes de produtos refrigerados de proteína vegetal dos EUA (BEEF POINT, 2017a).

Voltando para as tendências da pecuária brasileira em si, dadas as estreitas margens de lucro da carne em um cenário cada vez mais competitivo, a produtividade na indústria foca na melhoria da eficiência e na redução de custos. A abertura de capital e a internacionalização das empresas também se fazem presentes na grandes transformações ocorridas nacionalmente (CARVALHO; ZEN, 2017). A consolidação das estruturas multinacionais torna a coexistência com pequenos produtores praticamente impossível, ameaçando, portanto, uma importante fonte de renda para grupos mais pobres (HEINRICH BÖLL FOUNDATION, 2015).

No que diz respeito às mudanças na cadeia produtiva, apesar de certas mudanças apontarem para um maior grau na adoção de novas tecnologias, homogeneização de alguns processos, diversificação de atividades e novas formas de comercialização, a heterogeneidade é uma característica marcante na produção nacional. Sistemas considerados de alta qualidade, com tecnologia e gestão mais avançada, coexistem com sistemas extensivos, marcados por padrões precários, baixa produtividade e um alto impacto ambiental (CARVALHO; ZEN, 2017).

Especificamente no que diz respeito à pecuária bovina, a marcante preferência nacional pelos sistemas extensivos de baixa tecnologia e alto impacto ambiental são motivadas não apenas pela sua simplicidade, mas pelo seu baixo custo de produção (AMARAL et al., 2012). A reduzida dependência de insumos, como a forragem, aliada às

${ }^{137}$ A "carne artificial” ou carne produzida em laboratório é melhor abordada no item 3.2.4 desta dissertação. 
diversas facilidades na posse de terra, faz com que a produção de engorda de bovinos no Brasil esteja entre as mais baratas do planeta (CARVALHO; ZEN, 2017). Além disso, a pecuária tem sido escolhida por diversos produtores, especialmente em contextos de desmatamento, devido a sua alta liquidez econômica (VIEIRA, 2016).

Por mais que as lógicas extensivas mais impactantes ainda representem maioria da pecuária bovina nacional, a intensificação, com o seu respectivo aumento da produtividade devido a técnicas e tecnologias diversas, tem sido apontada como possível solução para uma produção futura mais sustentável (AMARAL et al., 2012). Entretanto, apesar de reduzir a necessidade de áreas para pastagem, dentre outros possíveis benefícios, a intensificação também traz consigo alguns problemas no que diz respeito à transferência de impactos para o setor agrícola e aos custos elevados.

Sob um ponto de vista econômico mais tradicional e reducionista ${ }^{138}$, o mercado de corte representa, tal qual o agronegócio como um todo, um futuro promissor para o Brasil, levando em conta que ainda há uma grande disponibilidade de terra e água no país (CARVALHO; ZEN, 2017). Por outro lado, sob uma perspectiva mais holística e sistêmica, levando em conta questões socioambientais, saúde pública, segurança alimentar, sobrevivência de pequenos produtores, dentre outros critérios abordados, ainda que haja uma intensificação da pecuária bovina, o cenário futuro de aumento na demanda e produção de carne no Brasil traz consigo diversas preocupações.

\subsection{As emissões da indústria de produção animal}

De acordo com a literatura investigada, o vegetarianismo é relevante em termos ambientais devido à forte relação existente entre a indústria de produção animal e os grandes problemas socioambientais modernos. Nossa sociedade gera diversos impactos ambientais, em escalas cada vez mais significativas, que têm como consequência problemáticas cada vez mais complexas. Nesse âmbito, seria possível discutir e aprofundar a influência e relevância da produção e consumo de carne em cada uma das questões ambientais abordadas no item 2.2. Entretanto, a questão das mudanças climáticas, mais especificamente sua causa antrópica central, as emissões de GEE, foi escolhida como foco deste trabalho por diversos motivos, conforme explicitado na introdução desta dissertação.

${ }^{138}$ Que não leva em conta riscos ou custos socioambientais e outras externalidades da indústria. 
A influência humana no aquecimento global e, portanto, nas mudanças climáticas, é, atualmente, um ponto consensual na comunidade científica. Em uma ampla revisão realizada por Cook et al. (2013) foi constatado que, dentre os trabalhos científicos que abordavam o tema, 97,2\% endossaram o aquecimento global antropogênico (AGA) ${ }^{139}$. Segundo o Quinto Relatório de Avaliação (AR5 ${ }^{140}$ ) do Painel Intergovernamental sobre Mudanças Climáticas (IPCC), o aquecimento global, estimado em aproximadamente $0,85^{\circ} \mathrm{C}$ entre o período de 1880 e 2012, é inequívoco (INTERGOVERNMENTAL PANEL ON CLIMATE CHANGE, 2014a). O consenso sobre a contribuição humana nas mudanças climáticas é cada vez mais evidente na comunidade científica internacional (COOK et al., 2013) e brasileira (ALISSON, 2018).

A principal causa disso, com elevado grau de certeza, são as emissões de GEE oriundas das atividades humanas. As estimativas do relatório mostram que, se tendências atuais de emissões atuais se mantiverem, o aquecimento poderá alcançar $4,8^{\circ} \mathrm{C}$ até $2100^{141}$, gerando diversas consequências ${ }^{142}$, dentre as quais podemos destacar: significativas alterações dos sistemas climáticos (com o aumento de eventos extremos, como ciclones ou ondas de calor); elevação do nível médio do mar; mudanças nas correntes marítimas; alterações nos ecossistemas e seus serviços; aumento dos processos de desertificação; perdas da biodiversidade; riscos para a segurança alimentar e para a saúde pública e até mesmo para o patrimônio histórico e cultural. O que afetará negativa e profundamente a política, a economia e a sociedade como um todo (INTERGOVERNMENTAL PANEL ON CLIMATE CHANGE, 2014a). Este cenário de mudanças climáticas possui, inclusive, o potencial de não só ameaçar, mas de extinguir a civilização humana como um todo (GLOBAL CHALLENGES FOUNDATION, 2018).

A Tabela 4 apresenta os cenários de mudança na temperatura média global para 2100. É preciso salientar que cenários que não contam com esforços adicionais para restringir as emissões atuais da humanidade levam a caminhos que variam entre RCP6.0 e RCP8.5.

\footnotetext{
${ }^{139}$ Logo, esta dissertação também parte do princípio do AGA.

${ }^{140}$ Em inglês, "Assessment Report".

${ }^{141}$ Mudança da temperatura média global da superfície do planeta referente ao cenário RCP8.5 (Representative Concentration Pathway 8.5) do AR5, que representa a projeção menos otimista, que diz respeito às redução de emissões antropogênicas de GEE, mas que, ainda assim, está dentro de uma faixa provável de ocorrência (INTERGOVERNMENTAL PANEL ON CLIMATE CHANGE, 2014a).

${ }^{142}$ É preciso ressaltar que o grau de probabilidade e confiabilidade variam entre as possíveis consequências.
} 
Tabela 4 - Possíveis cenários de mudança do clima para 2100.

\begin{tabular}{|c|c|c|c|}
\hline Cenário & Detalhamento & $\begin{array}{c}\text { Média de } \\
\text { aquecimento } \\
\text { global }\left({ }^{\circ} \mathrm{C}\right)\end{array}$ & $\begin{array}{c}\text { Faixa de } \\
\text { variação de } \\
\text { provável }\left({ }^{\circ} \mathrm{C}\right)\end{array}$ \\
\hline RCP2.6 & $\begin{array}{l}\text { Cenário com uma mitigação rigorosa de } \\
\text { emissões de GEE }\end{array}$ & 1 & 0,3 até 1,7 \\
\hline RPC4.5 & $\begin{array}{l}\text { Cenário intermediário, com mitigação } \\
\text { parcial de emissões de GEE }\end{array}$ & 1,8 & 1,1 até 2,6 \\
\hline RCP6.0 & $\begin{array}{l}\text { Cenário intermediário, com mitigação } \\
\text { parcial de emissões de GEE }\end{array}$ & 2,2 & 1,4 até 3,1 \\
\hline RCP8.5 & Cenário com alto grau de emissões de GEE & 3,7 & 2,6 até 4,8 \\
\hline
\end{tabular}

Fonte: Adaptado de Intergovernmental Panel on Climate Change, 2014a.

Tratando-se da relação do assunto com a pecuária, um dos estudos mais proeminentes que procurou quantificar a contribuição da produção animal para o AGA foi o relatório “Livestock's long shadow: environmental issues and options", de 2006. Segundo o estudo, a pecuária seria responsável por cerca de $18 \%$ das emissões antropogênicas totais de GEE do planeta, em dióxido de carbono equivalente $\left(\mathrm{CO}_{2} \mathrm{eq}\right)^{143}$ (FOOD AND AGRICULTURE ORGANIZATION OF THE UNITED NATIONS, 2006), sendo que:

\begin{abstract}
O setor pecuário é responsável por $9 \%$ das emissões antropogênicas de $\mathrm{CO}_{2}$. A maior parte disso deriva de mudanças no uso da terra - especialmente do desmatamento - causadas pela expansão de pastagens e terras aráveis para o cultivo de ração. A pecuária é responsável por partes muito maiores de alguns gases com potencial muito maior para aquecer a atmosfera. O setor emite 37 por cento de metano antropogênico (com 23 vezes o potencial de aquecimento global de $\mathrm{CO}_{2}$ ), a maior parte da fermentação entérica por ruminantes. Emite $65 \%$ de óxido nitroso $\left(\mathrm{N}_{2} \mathrm{O}\right)$ antropogênico (com 296 vezes o potencial de aquecimento global de $\mathrm{CO}_{2}$ ), a grande maioria do esterco. O estoque vivo também é responsável por quase dois terços $(64 \%)$ das emissões antrópicas de amônia, que contribuem significativamente para a chuva ácida e a acidificação dos ecossistemas (FOOD AND AGRICULTURE ORGANIZATION OF THE UNITED NATIONS, 2006. p. XXI, tradução nossa).
\end{abstract}

O estudo da FAO, que utilizou uma Avaliação do Ciclo de Vida (ACV) como técnica de quantificação, demonstrou um alto nível de emissões no setor, uma vez que, segundo o trabalho, o setor de transportes, comumente colocado como uma das maiores fontes de GEE, seria responsável por uma quantidade menor do que a indústria de produção animal (FOOD

\footnotetext{
${ }^{143}$ Medida padronizada utilizada internacionalmente para quantificar os potenciais de aquecimento global de diferentes GEE e outros componentes. Trata-se da concentração de uma certa mistura de dióxido de carbono $\left(\mathrm{CO}_{2}\right)$, em condições específicas, que geraria uma forçante radiativa (FR) equivalente a uma quantidade ao componente ou gás em questão, em um dado momento e condição (INTERGOVERNMENTAL PANEL ON CLIMATE CHANGE, 2014c).
} 
AND AGRICULTURE ORGANIZATION OF THE UNITED NATIONS, 2006). Esta informação trouxe para o setor uma grande responsabilidade e relacionou fortemente a mitigação das mudanças climáticas com questões relacionadas à produção de carne.

Isso desdobrou uma grande discussão envolvendo ativistas contrários a produção de carne, ambientalistas, representantes da indústria pecuária e de alguns pesquisadores que contestaram os números do relatório, em especial, envolvendo o Dr. Frank Mitloehner, da Universidade da Califórnia. Mitloehner alegou que os números das emissões do setor em questão foram calculados de forma diferente do setor de transporte, crítica aceita de forma aberta por Pierre Gerber, pesquisador membro da FAO e um dos responsáveis pela próxima publicação da organização sobre o assunto ${ }^{144}$ (JAMIESON, 2010).

É importante destacar que, tanto nacionalmente, quanto internacionalmente, as emissões variam de acordo com o tipo de produção, tanto na quantidade de $\mathrm{CO}_{2}$ eq total emitida, quanto na diversidade e distribuição de poluentes. Também é preciso salientar que, dessa forma, a carne bovina se destaca como a produção pecuária mais impactante em termos de GEE $^{145}$ (FOOD AND AGRICULTURE ORGANIZATION OF THE UNITED NATIONS, 2013a; TOORN; BROEK; WORRELL, 2017).

Antes da publicação do próximo relatório da FAO sobre o assunto, surgiu, em 2009, um polêmico estudo com grande repercussão, realizado por Goodland e Anhang (2009), especialistas em avaliação ambiental do World Watch Institute (WWI). No trabalho, que contestou a publicação de 2006 da FAO, os pesquisadores declararam alguns pontos que acabaram por suprimir a real contribuição do gado para as emissões de GEE. Dentre as principais críticas dos pesquisadores com relação à metodologia utilizada na publicação da FAO, é possível citar o uso do potencial de aquecimento global (GWP) ${ }^{146}$ de 100 anos do metano, ao invés do GWP de $20 \operatorname{anos}^{147}$, a exclusão das emissões referentes à respiração

\footnotetext{
${ }^{144} \mathrm{O}$ relatório "Tackling Climate Change Through Livestock: A global assessment of emissions and mitigation opportunities", de 2013 (FOOD AND AGRICULTURE ORGANIZATION OF THE UNITED NATIONS, 2013a).

${ }^{145}$ A disparidade da carne bovina nesse sentido é melhor abordada no item 4.1 e 4.2.2.

${ }^{146}$ Em inglês, Global Warming Potencial (GWP): trata-se de "um índice que mede a forçante radiativa após uma emissão de uma massa unitária de uma dada substância, acumulada ao longo de um período de tempo escolhido, relativa à da substância de referência, o dióxido de carbono" (INTERGOVERNMENTAL PANEL ON CLIMATE CHANGE, 2014c, p.124).

${ }^{147}$ A mudança é significativa, pois o GWP de 20 anos do metano é consideravelmente maior do que o 100 anos, sendo que, atualmente, equivalem a 72 e 25 , respectivamente, de acordo com o IPCC (INTERGOVERNMENTAL PANEL ON CLIMATE CHANGE, 2018).
} 
animal $^{148}$ e a subestimação do montante de animais na indústria. Mantendo o GWP de 100 anos para todos os GEE, com exceção do metano, e adotando outras mudanças, o percentual de contribuição da pecuária para o AGA, seria de pelo menos 51\%. Segundo os autores,

\begin{abstract}
Se esse argumento estiver correto, isso implica que a substituição de produtos animais por alternativas melhores seria a melhor estratégia para reverter as mudanças climáticas. Na verdade, essa abordagem teria efeitos muito mais rápidos nas emissões de gases de efeito estufa e em suas concentrações atmosféricas do que em ações para substituir os combustíveis fósseis por energias renováveis (GOODLAND; ANHANG, 2009, p. 11 tradução nossa).
\end{abstract}

Apesar da discrepância dos resultados com outros trabalhos similares, o estudo de Goodland e Anhang (2009) foi relativamente bem recebido e, inclusive, citado em algumas agências da $\mathrm{ONU}^{149}$, instituições internacionais, trabalhos acadêmicos ${ }^{150}$ e na mídia de modo geral. Entretanto, isso gerou diversas contestações. Em um artigo de Herrero et al. (2011) são apontadas diversas críticas ao trabalho publicado pelo WWI, como o fato deste não ter sido revisado por pares, ter supostamente enfatizado demais os impactos negativos da pecuária, bem como a errônea utilização do GWP de 20 anos do metano. Também é ressaltada a importância de serem adotadas as convenções e metodologias bem estabelecidas cientificamente, como aquelas utilizadas pelo IPCC. Apesar disso, Herrero et al. (2011) concorda com a opinião de Goodland e Anhang (2009) de que as estimativas sobre mudanças de uso da terra, processamento e transporte, utilizadas no trabalho da FAO (2006), são deliberadamente conservadoras.

Em 2013, a FAO publicou o relatório "Tackling climate change through livestock: A global assessment of emissions and mitigation opportunities", um trabalho que abordou não apenas as emissões da pecuária, mas as possibilidades de mitigação existentes dentro deste âmbito. De acordo com o estudo, o setor seria responsável por 14,5\% das emissões antrópicas de GEE, sendo que, dentro desse montante, a produção de carne bovina e de leite seriam as maiores contribuintes, representando $41 \%$ e $20 \%$ das emissões na indústria animal, respectivamente, seguidas pela da carne de porco $(9 \%)$ e de aves $(8 \%)$. É preciso destacar

\footnotetext{
${ }^{148}$ As convenções mais adotadas tratam a respiração animal como sendo integrantes ao ciclo de carbono de curto prazo e, portanto, são excluídas dos cálculos (GOODLAND; ANHANG, 2009).

${ }^{149}$ Como, por exemplo, pela Organização das Nações Unidas para a Educação, a Ciência e a Cultura (UNESCO) (KANALY et al., 2010) e pelo Programa das Nações Unidas para o Meio Ambiente (UNEP) (UNITED NATIONS ENVIRONMENT PROGRAMME, 2013).

${ }^{150}$ Como nos trabalhos de Mishori (2017), Herrero et al. (2011) e Baker, Shin e Kim (2016).
} 
também que, nessa indústria em questão, as principais fontes de GEE são a produção e processamento de ração (45\%), a fermentação entérica ${ }^{151}(39 \%)$ e o estrume (10\%) (FOOD AND AGRICULTURE ORGANIZATION OF THE UNITED NATIONS, 2013a).

Apesar de ambos os relatórios da FAO, de 2006 e de 2013, basearem-se em ACV, é preciso ressaltar que a segunda publicação possui algumas diferenças com relação à primeira, dentre as quais estão a mudanças nos valores de GWP atualizados pelo IPCC, a utilização de uma nova estrutura computacional, dentre outras mudanças.

No entanto, os fatores que levaram a considerável redução no percentual total de emissões estão relacionados, especialmente, com a contabilização de GEE oriundos do estrume e das mudanças no uso da terra. Em ambos os casos, por conta de questões metodológicas, houve uma considerável redução nos valores. As emissões estimadas relacionadas ao desmatamento para abertura de pastagens ou para produção de forragem, reduziram de 2,4 para 0,65 $\mathrm{Gt}$ (gigatoneladas) de $\mathrm{CO}_{2} \mathrm{eq}$ (FOOD AND AGRICULTURE ORGANIZATION OF THE UNITED NATIONS, 2013a).

Não existe uma única metodologia universal para mensurar emissões de GEE. Entretanto, o IPCC fornece diretrizes e métodos, geralmente aceitos na comunidade científica, para abordar o assunto ${ }^{152}$. A estimativa de 2013 da FAO seguiu certas diretrizes estabelecidas pelo IPCC e, atualmente, é a mais utilizada como referência no assunto ${ }^{153}$. Entretanto, a abordagem de ciclo de vida utilizada neste trabalho difere da metodologia de inventários de GEE comumente utilizada e recomendada pelo $\mathrm{IPCC}^{154}$, não apenas na forma de mensuração, mas também nas próprias categorias de setores estabelecidos para atribuir parcelas de emissões.

As abordagens focadas na cadeia produtiva, como a ACV, rastreiam todas as emissões relacionadas à produção pecuária, incluindo as indiretas, como, por exemplo, os GEE

\footnotetext{
${ }^{151}$ Processo digestivo de herbívoros ruminantes que libera metano na atmosfera.

${ }^{152}$ Como, por exemplo, os valores de GWP de diferentes gases e diretrizes para elaboração de inventários de emissões.

${ }^{153}$ Apesar de um maior grau de aceitação na comunidade científica e de seu uso crescente em estudos acadêmicos, as outras estimativas não deixam de ser citadas frequentemente em diversos trabalhos nacionais, internacionais e na mídia, o que apenas ressalta a controvérsia no assunto.

${ }^{154}$ É exigido que os países que reportam o perfil das suas emissões na Convenção-Quadro das Nações Unidas sobre a Mudança do Clima (UNFCCC) utilizem as diretrizes para inventários nacionais de GEE do IPCC (UNITED NATIONS FRAMEWORK CONVENTION ON CLIMATE CHANGE, 2018).
} 
oriundos da produção de forragem e do transporte dos animais ${ }^{155}$ (FOOD AND AGRICULTURE ORGANIZATION OF THE UNITED NATIONS, 2013a). Já os inventários nacionais do IPCC são divididos por categorias setoriais, tais como a agropecuária, transporte e mudanças no uso do solo, o que acaba por diluir as emissões indiretas envolvidas com a pecuária em outras atividades.

É possível citar a recomendação, feita por diversos cientistas ambientais, de que as emissões indiretas, incluindo aquelas referentes à geração de insumos, produção, transporte, processamento, consumo e descarte, devem ser contabilizadas em levantamentos de GEE do setor pecuário (HEINRICH BÖLL FOUNDATION, 2015), o que justifica a abordagem da ACV. Por outro lado, também existe a notável importância do IPCC, bem como de suas diretrizes metodológicas, em termos de convenção e aceitação dentro da comunidade científica no que tange os temas do aquecimento global e das mudanças climáticas (LEITE, 2015), o que, por sua vez, legitima a metodologia de inventário proposta pela organização. Sem dúvida, não se tratam de duas perspectivas excludentes ou em competição, mas são escolhas que levam a resultados diferentes para uma mesma questão ${ }^{156}$.

Nas estatísticas mais gerais do AR5, por exemplo, as emissões da pecuária são consideradas dentro da categoria denominada como AFOLU (Agriculture, Forestry and Other Land Use), a qual consiste em uma rede que inclui agropecuária, silvicultura e outros usos do solo, e que corresponde a $24 \%$ das emissões antropogênicas totais de GEE, como mostra a Figura 4.

Indo além das principais estatísticas que atribuem uma maior ou menor responsabilidade da pecuária para o AGA, é preciso considerar que existem diversas formas de abordar essa questão. Pode-se destacar, entretanto, que a principal variante entre as estimativas do IPCC e da FAO é a forma como as emissões indiretas de mudanças no uso do solo são alocadas (HERRERO et al., 2015).

\footnotetext{
${ }^{155}$ Existem trabalhos, como o de Aan de Torn, Van den Broek e Worrel (2017), que abordam especificamente as incertezas e fatores que devem ser considerados no estudo de emissões de GEE em diferentes etapas dos ciclos de vida da cadeia produtiva da carne.

${ }^{156}$ No caso, "qual a contribuição da pecuária para o AGA?".
} 
Figura 4- Emissões de GEE por diferentes setores econômicos

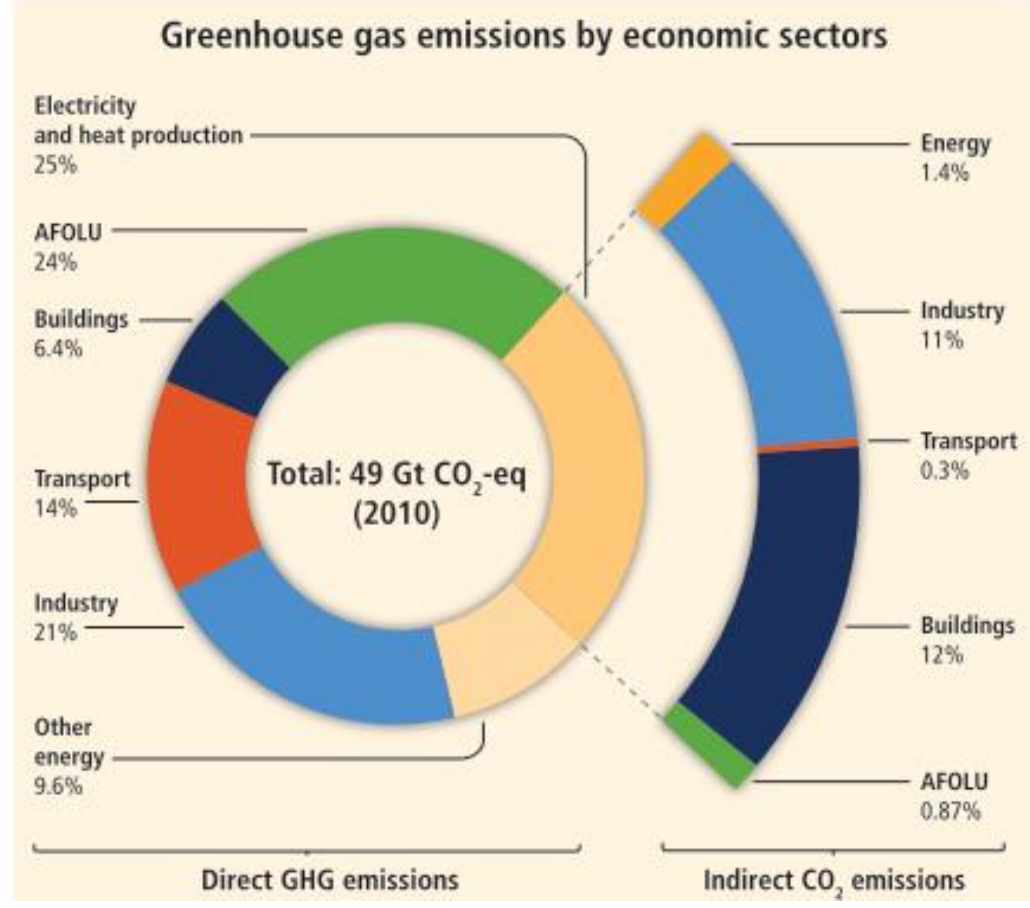

Fonte: Intergovernmental Panel nn Climate Change, 2014a.

É possível encontrar outros trabalhos que mensuram a contribuição da pecuária em nível internacional e nacional, entretanto, os mais citados na bibliografia estudada foram as estimativas da FAO e do $\mathrm{WWI}^{157}$. Além disso, eles representam bem a amplitude e discrepância nos estudos dentro desta controvérsia e levantam os principais pontos de discordância, como, por exemplo, o GWP do metano e a contabilização das emissões oriundas das mudanças no uso do solo. Outras estimativas existentes, que podem trazer diferentes percentuais de contribuição da pecuária para o $\mathrm{AGA}^{158}$, possuem como principal diferença entre si a inclusão ou exclusão das emissões indiretas, como as oriundas da produção de soja para ração e do desmatamento para abertura de pastagens, por exemplo (HEINRICH BÖLL FOUNDATION, 2014).

Como é comum ocorrer em uma controvérsia sociotécnica (VENTURINI, 2010a), a falta de consenso científico e a variabilidade nos valores, com relação à contribuição da pecuária para as emissões de GEE, acabam por gerar confusão em formuladores de políticas

\footnotetext{
${ }^{157}$ Constatação feita durante a realização deste trabalho. Tal afirmação, no entanto, poderá ser melhor embasada, em estudos futuros, com o uso de análises bibliométricas.

${ }^{158}$ Como, por exemplo, os 8\% citados no trabalho de O'Mara (2011), ou 32\% mencionados no atlas da Heinrich Boll Foundation (2015).
} 
públicas e na sociedade de modo geral (HERRERO et al., 2011). Em conclusão, neste ponto, que representa uma questão basal para iniciar reflexões sobre consequências socioambientais e a relevância de mudanças na dieta para a sustentabilidade da nossa sociedade moderna, a relação entre o sistema-carne e o aquecimento global já se estabelece como um ponto controverso no que diz respeito ao seu grau de influência.

\subsubsection{Gases de efeito estufa na pecuária brasileira}

Tratando-se especificamente do Brasil, há também certa controvérsia no que diz respeito à contribuição da pecuária nas emissões de GEE, sendo que, de modo geral, os pontos discordantes entre as estimativas estão relacionados a questões bem similares à controvérsia das emissões globais do setor. Opções metodológicas e a inclusão de emissões indiretas, dentre outras escolhas, geraram estudos cujos resultados divergem significativamente entre si.

Segundo dados do Sistema de Estimativa de Emissões de Gases de Efeito Estufa (SEEG), produzido pelo Observatório do Clima $^{159}$ (2017), a agropecuária, como um todo, foi responsável por $22 \%$ das emissões de GEE brasileiras ${ }^{160}$, sendo que, deste montante, $84 \%$ são provenientes da produção animal. Ou seja, nesse trabalho, aproximadamente $18,5 \%$ das emissões nacionais são atribuídas ao subsetor da pecuária. O relatório em questão seguiu as recomendações e moldes para elaboração de inventários do IPCC; logo, o montante de 18,5\% não engloba certas emissões indiretas como, por exemplo, aquelas referentes a mudanças no uso da terra para abertura de pastagens, sendo que estas se diluem em outras categorias, como mudança no uso do solo.

\footnotetext{
${ }^{159}$ Trata-se de uma organização da qual participam cerca de 37 entidades da sociedade civil brasileira, como o Greenpeace Brasil, o Instituto de Manejo e Certificação Florestal e Agrícola (IMAFLORA), o Instituto Socioambiental (ISA), a WWF Brasil, o SOS Mata Atlântica, dentre outros. A organização tem como objetivo tratar das mudanças climáticas em um contexto brasileiro.

${ }^{160}$ Valor referente às estimativas de emissões brutas, ou seja, não é descontada, na estimativa, a remoção do $\mathrm{CO}_{2}$ pelo crescimento de vegetação (OBSERVATÓRIO DO CLIMA, 2018b).
} 
Figura 5 - Emissões de GEE no Brasil, por atividade econômica em 2015

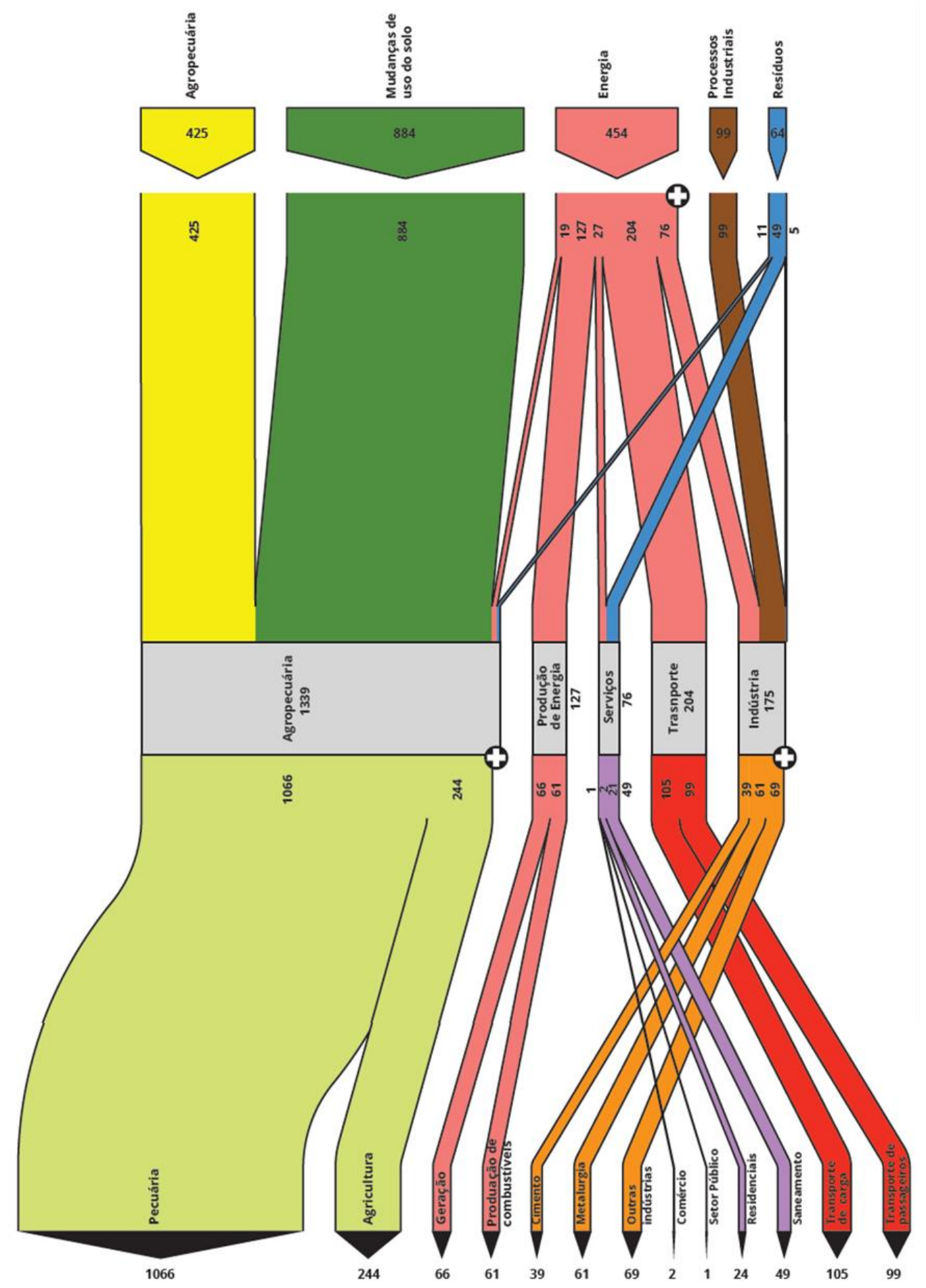

Fonte: Observatório do Clima, 2017.

Ainda tratando das estimativas feitas pelo Observatório do Clima (2017), é necessário ressaltar que reorganizando as emissões de GEE brasileiras por atividade econômica, e não por setores, já torna possível identificar um absoluto protagonismo da pecuária. A Figura 5 
mostra essa reorganização em que, no topo, percebe-se a configuração por setores e na parte de baixo é separada pelas atividades econômicas. Com isso, pode-se identificar que, das 1886 milhões de toneladas de $\mathrm{CO}_{2}$ eq emitidas no país, 1066 milhões odem ser atribuidas à atividade pecuária. Ou seja, observando os mesmos dados sob esta outra ótica, é possível considerar que a indústria de produção animal corresponde a cerca de $60 \%$ do que é emitido no Brasil. É notável a diferença nos valores que podem ser estabelecidos, dentro de um mesmo estudo e metodologia, em função do modo como se observa e se agrupa as emissões.

É possível, também, citar a última Estimativa Anual de Emissões de Gases de Efeito Estufa no Brasil, realizada pelo Ministério da Ciência, Tecnologia e Inovação (2017), em que todo setor agropecuário corresponderia a $25 \%$ das emissões antrópicas brutas de GEE nacionais. Como o levantamento também seguiu diretrizes técnicas estabelecidas pelo IPCC, não é possível identificar separadamente a contribuição da pecuária. Entretanto, o estudo aponta que maior parte dos GEE referentes à agropecuária (57\%) se dá pela fermentação entérica de ruminantes. Observa-se que a mesma questão da diluição da contribuição da pecuária em outras categorias se aplica nesta estimativa, uma vez que a conversão de florestas em pastagem é, segundo o levantamento, o maior fator contribuinte para o montante de emissões brutas do setor de mudanças no uso do solo ${ }^{161}$.

Outras estimativas, que circulam em estudos acadêmicos e na mídia, podem ser encontradas. A contribuição atribuída à pecuária nas emissões de GEE do Brasil varia muito: é possível encontrar citações que apontam $17 \%{ }^{162}$ (OBSERVATÓRIO DO CLIMA, 2018a), 18,5\% (OBSERVATÓRIO DO CLIMA, 2017), 42\% (ZEN et al., 2008) até 69\% (LAHSEN, 2017). É preciso destacar, portanto, que, apesar da publicação de inventários que seguem as convenções metodológicas do IPCC, ainda existem opiniões e posições consideravelmente divergentes a respeito (AMARAL et al., 2012). Apesar disso, é possível observar que, de modo geral, o setor pecuarista brasileiro está associado com uma parcela significativa das emissões nacionais de GEE (MICHELINI; LAHSEN, 2016), ainda que boa parte destas sejam atribuídas a outras categorias de forma indireta.

\footnotetext{
${ }^{161}$ Setor que mais contribui, segundo a estimativa, correspondendo a $38 \%$ das emissões brutas de GEE no Brasil (MINISTÉRIO DA CIÊNCIA, TECNOLOGIA, INOVAÇÕES E COMUNICAÇÕES, 2017).

${ }^{162}$ Dado referente ao rebanho bovino, especificamente.
} 
Por fim, percebe-se que os resultados obtidos dependem significativamente de como as informações são interpretadas, agrupadas e apresentadas. Em todos os casos observados, porém, fica claro que a pecuária brasileira:

- Tem como fonte principal de GEE a criação de gado bovino de corte e de leite;

- Emite diretamente maior parte dos GEE, através da fermentação entérica $\left(\mathrm{CH}_{4}\right)$, com uma parcela de contribuição menor oriunda de dejetos dos animais $\left(\mathrm{CH}_{4}\right.$ e $\left.\mathrm{N}_{2} \mathrm{O}\right)$ e de fertilizantes sintéticos $\left(\mathrm{N}_{2} \mathrm{O}\right)$;

- Está associada com a conversão, envolvendo desmatamento e queimadas, de florestas em pastagens, processo que compõe a maioria das emissões brutas $\left(\mathrm{CO}_{2}\right)$ em mudanças no uso do solo no país.

Por fim, a Tabela 5 sintetiza as principais estimativas do percentual de emissões antrópicas de GEE atribuídas à pecuária, no nível internacional e nacional. É notável a variação entre valores estabelecidos pelos diferentes estudos.

Tabela 5 - Percentuais das emissões antrópicas de GEE atribuídos à pecuária em diferentes estudos

\begin{tabular}{|c|c|c|c|}
\hline $\begin{array}{c}\text { Percentual } \\
\text { estabelecido }\end{array}$ & Escopo & Metodologia & Referência \\
\hline $8 \%$ & Internacional & Inventário de GEE & (O’MA2RA, 2011) \\
\hline $14,5 \%$ & Internacional & $\mathrm{ACV}$ & $\begin{array}{l}\text { (FOOD AND AGRICULTURE } \\
\text { ORGANIZATION OF THE } \\
\text { UNITED NATIONS, 2013a) }\end{array}$ \\
\hline $18 \%$ & Internacional & $\mathrm{ACV}$ & $\begin{array}{l}\text { (FOOD AND AGRICULTURE } \\
\text { ORGANIZATION OF THE } \\
\text { UNITED NATIONS, 2006) }\end{array}$ \\
\hline $51 \%$ & Internacional & $\mathrm{ACV}$ & (GOODLAND; ANHANG, 2009) \\
\hline $18,5 \%$ & Brasil & Inventário de GEE & $\begin{array}{l}\text { (OBSERVATÓRIO DO CLIMA, } \\
2017 \text { ) }\end{array}$ \\
\hline $42 \%(1)$ & Brasil & Inventário de GEE & (ZEN et al., 2008) \\
\hline
\end{tabular}

Fonte: Elaborado pelo autor.

(1) Tal estimativa, entretanto, não considera a existência de emissões geradas por queimadas e desmatamento para estabelecer este percentual, vide página 4 de Zen et al. (2008). 


\subsubsection{Metano, óxido nitroso e os potenciais de aquecimento global}

Uma grande e significativa parcela das emissões de GEE da pecuária, tanto no Brasil quanto mundo, são atribuídas ao metano $\left(\mathrm{CH}_{4}\right)$ - cuja fonte é a fermentação entérica, o processo digestivo de mamíferos ruminantes, tais como bovinos, ovinos, caprinos e bubalinos, e ao óxido nitroso $\left(\mathrm{N}_{2} \mathrm{O}\right.$ ) (FOOD AND AGRICULTURE ORGANIZATION OF THE UNITED NATIONS, 2013a). Para compreender a relevância destes gases no que diz respeito ao efeito estufa, é necessário abordar questões de natureza físico-químicas.

Os GEE, sejam eles de fontes antropogênicas ou naturais, elevam a temperatura atmosférica através da absorção de radiação infravermelha (IV), majoritariamente emitida pela superfície terrestre (BAIRD; CANN, 2011). Esse processo ocorre quando a radiação IV incidente interage com a molécula do GEE em questão, gerando alterações vibracionais na mesma. Cada uma destas alterações ${ }^{163}$ está relacionada com a absorção de uma determinada faixa de frequência dentro do espectro infravermelho, sendo que cada espécie química vai possuir um conjunto específico de variações. Por fim, isso significa que a distribuição das bandas de absorção no espectro IV, por conta das particularidades da geometria daquela molécula, influencia diretamente no GWP de um GEE (ATKINS; JONES, 2012; LOBATO; LAGO, 2004; TOLENTINO; ROCHA-FILHO, 1998).

Observando os espectros de absorção de IV dos principais GEE encontrados na atmosfera, expressos na Figura 6, é possível perceber, observando as linhas vermelhas, que o $\mathrm{CH}_{4}$ possui bandas de absorção que não se sobrepõem às do $\mathrm{CO}_{2}{ }^{164}$. Além disso, os picos de absorção do $\mathrm{CH}_{4}$ que se sobrepõem aos do vapor de água ${ }^{165}$ são maiores e, portanto, possuem um potencial de absorção maior nestes pontos. Isso ocorre de maneira ainda mais significativa com o $\mathrm{N}_{2} \mathrm{O}$.

\footnotetext{
${ }^{163}$ Existem alguns tipos de alterações vibracionais possíveis, que podem ocorrer a depender da geometria molecular: estiramento assimétrico, estiramento simétrico e as deformações angulares simétricas no plano, assimétricas no plano, simétricas fora do plano e assimétricas fora do plano (HAACK, 2010).

${ }^{164}$ Se uma sobreposição nas bandas de absorção de diferentes gases ocorre, o valor de GWP destes acaba sendo reduzido.

${ }^{165} \mathrm{O}$ vapor de água, cuja maioria das emissões são oriundas de fontes não antrópicas, trata-se do GEE mais abundante na atmosfera (NATIONAL CENTERS FOR ENVIRONMENTAL INFORMATION, 2018).
} 
Figura 6 - Bandas de absorção de infravermelho dos principais GEE

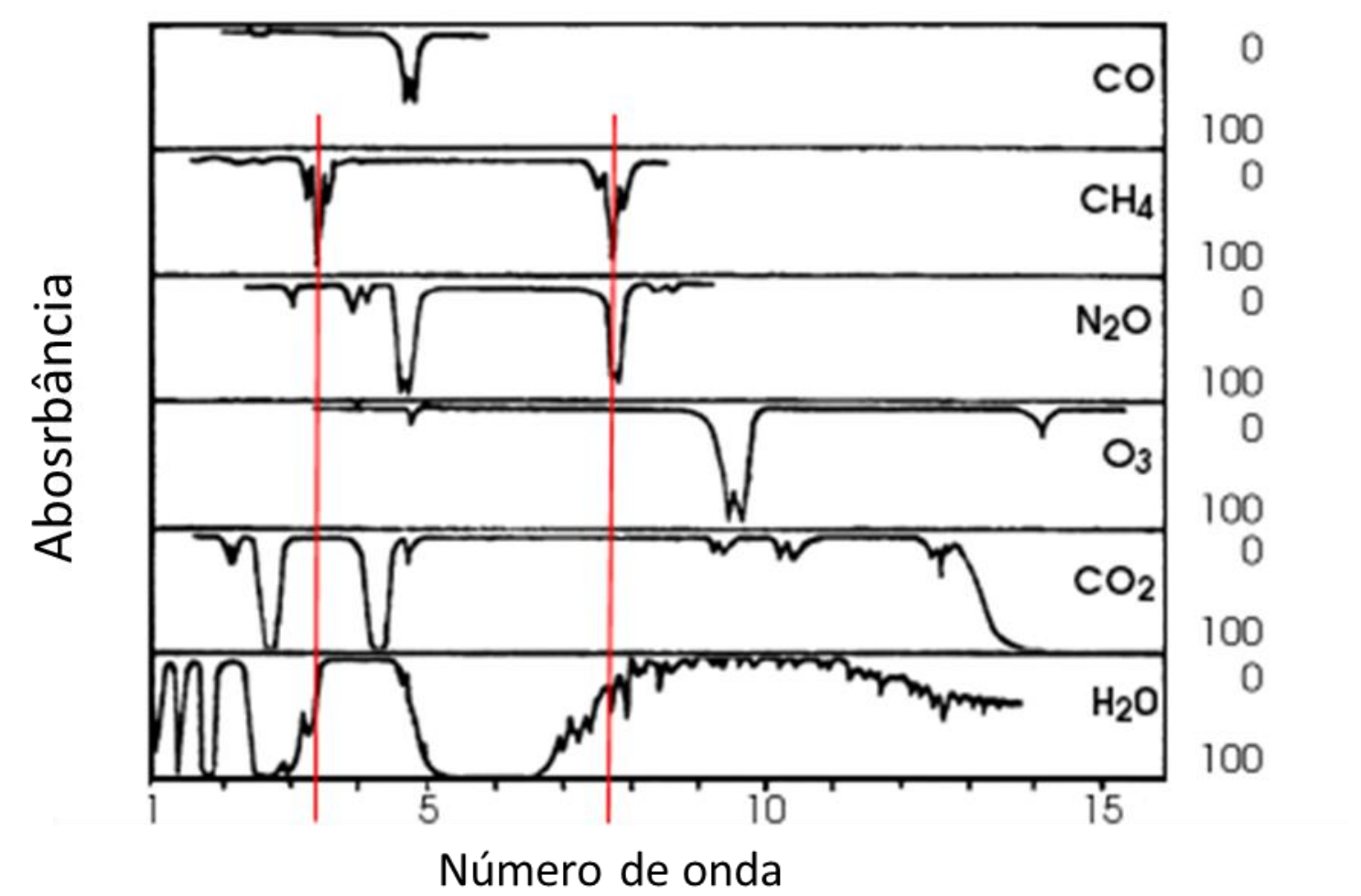

Fonte: Adaptado de NASA, 1999.

Podemos concluir, portanto, que estes fatores fazem com que o $\mathrm{CH}_{4}$ e o $\mathrm{N}_{2} \mathrm{O}$ tenham um GWP maior do que o $\mathrm{CO}_{2}$, o que faz, também, com que seus impactos potenciais no AGA sejam, em termos relativos ${ }^{166}$, mais elevados.

Os dejetos dos animais e a utilização de fertilizantes sintéticos nitrogenados constituem a maior parte das emissões de $\mathrm{N}_{2} \mathrm{O}$ da pecuária. Ainda que, no setor pecuário, a quantidade destas emissões seja menor em termos absolutos que as de $\mathrm{CH}_{4}$ e de $\mathrm{CO}_{2}$, o elevado fator de GWP do $\mathrm{N}_{2} \mathrm{O}$ acaba conferindo grande importância ao mesmo. Utilizando valores atualizados do GWP, estabelecidos pelo IPCC, é possível destacar que 1 tonelada de $\mathrm{N}_{2} \mathrm{O}$ causa o mesmo efeito no aquecimento da atmosfera que 310 toneladas de $\mathrm{CO}_{2}$, em um horizonte de tempo de 100 anos (INTERGOVERNMENTAL PANEL ON CLIMATE CHANGE, 2018).

No caso do metano, há um contínuo debate sobre seu real potencial de aquecimento na atmosfera e os valores de GWP do mesmo tem sofrido revisões nos últimos anos (ETMINAN

\footnotetext{
${ }^{166}$ Em termos absolutos o $\mathrm{CO}_{2}$ ainda é o maior contribuinte para o AGA, dada a quantidade deste GEE que é emitida (INTERGOVERNMENTAL PANEL ON CLIMATE CHANGE, 2014a).
} 
et al., 2016; SHINDELL et al., 2009). Segundo o estudo de Etminan et al. (2016), a FR do metano seria

cerca de $25 \%$ mais alta (aumentando de $0,48 \mathrm{Wm}-2$ para $0,61 \mathrm{Wm}-2$ ) em comparação com o valor da avaliação do Painel Intergovernamental sobre Mudanças Climáticas (IPCC) de 2013; o potencial de aquecimento global de 100 anos é 14\% superior ao valor do IPCC (ETMINAN et al., 2016, p. 615 tradução nossa).

Além disso, é preciso destacar a discrepância entre o GWP de 20 e de 100 anos do $\mathrm{CH}_{4}$, que correspondem aos valores de 72 e 21, respectivamente. As convenções estabelecidas pelo IPCC recomendam a utilização do GWP de 100 anos. Entretanto, uma vez que o $\mathrm{CH}_{4}$ possui uma vida atmosférica média ${ }^{167}$ de 12 anos (INTERGOVERNMENTAL PANEL ON CLIMATE CHANGE, 2014a), em um curto período de tempo este gás pode contribuir mais para o aquecimento global do que o fator 21 sugere (GOODLAND; ANHANG, 2009; SHINDELL et al., 2009).

O gráfico apresentado na Figura 7, retirado do AR5, mostra como a contribuição setorial nas emissões de GEE totais muda em função de GWP de diferentes escalas de tempo. É possível observar que a contribuição do setor agropecuário (agriculture) se eleva consideravelmente no gráfico B, o que se deve, especialmente, pela diferença entre os valores de GWP de 20 e de 100 anos do $\mathrm{CH}_{4}$ (INTERGOVERNMENTAL PANEL ON CLIMATE CHANGE, 2014a).

Figura 7 - Emissões de GEE por setores econômicos com diferentes valores de GWP

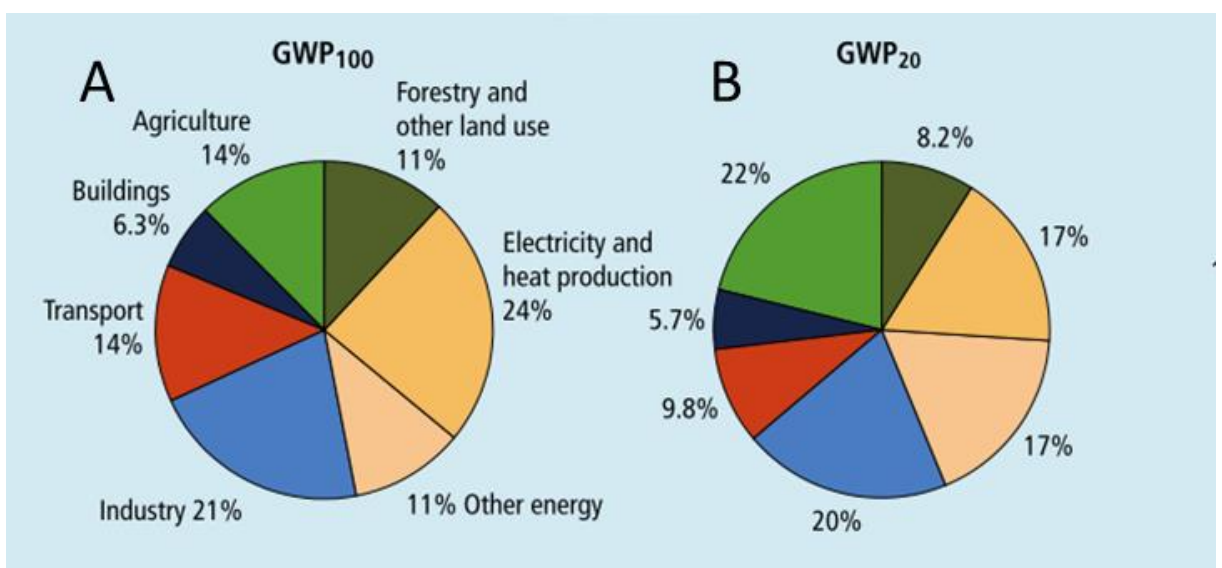

Fonte: Intergovernmental Panel on Climate Change, 2014a.

${ }^{167}$ Outro fator que influencia diretamente o valor do GWP de um determinado GEE. 
Logo, a variação entre os percentuais de emissões de GEE atribuídos à pecuária se dá, não apenas pela escolha entre a utilização de um GWP de 20 ou de $100 \operatorname{anos}^{168}$, mas, pela variação nos fatores de GWP ${ }^{169}$. A constante revisão destes potenciais (ETMINAN et al., 2016; SHINDELL et al., 2009), bem como a discordância na utilização dos mesmos (GOODLAND; ANHANG, 2009), adiciona incerteza à problemática e aumenta a disparidade entre possíveis resultados.

\subsubsection{Mudanças no uso do solo, produção de forragem e outras emissões indiretas}

Como colocado anteriormente, uma grande parcela das emissões da indústria de produção animal, geralmente as indiretas, acaba sendo alocada em outras categorias ou setores.

A alta demanda de forragem pela pecuária acaba por impulsionar e pressionar a produção agrícola em nível nacional e internacionalmente. Como já detalhado, cerca de 35\% da produção agrícola mundial (em massa) é destinada para a alimentação de animais (FOLEY et al., 2011) e, se consideramos também a somatória de todos os subprodutos agregados à alimentação animal, tais como pasta de semente de soja, palha e colza, é possível afirmar que três quartos de todas as terras de cultivo do planeta são utilizadas na produção de forragem (HEINRICH BÖLL FOUNDATION, 2015). Consequentemente, grande parte dos GEE oriundos da agricultura também está relacionada com a produção animal e, dependendo da metodologia utilizada, podem ou não ser considerados como emissões da pecuária.

Os estudos que utilizam ACV geralmente costumam incluir nas estimativas da pecuária as emissões da produção de forragem, da transformação de florestas em pastagens e do transporte e processamento dos animais, enquanto os inventários realizados com base nas diretrizes do IPCC não o fazem. Além de indicar uma certa controvérsia sociotécnica no assunto, isso acaba trazendo confusão para a população e para os formuladores de políticas (HERRERO et al., 2011).

\footnotetext{
${ }^{168}$ Questão apresentada anteriormente e especialmente abordada nas críticas de Goodlan e Anhang (2009).

${ }^{169}$ Como é o caso do estudo da FAO de 2013, que utilizou GWP atualizados para o metano, diferentes daqueles utilizados no relatório de 2006 (FOOD AND AGRICULTURE ORGANIZATION OF THE UNITED NATIONS, 2013a).
} 
Além disso, a categoria "agropecuária", utilizada por alguns estudos (MINISTÉRIO DA CIÊNCIA, TECNOLOGIA, INOVAÇÕES E COMUNICAÇÕES, 2017; OBSERVATÓRIO DO CLIMA, 2017), une duas atividades que possuem uma disparidade muito grande entre si, tanto no que diz respeito às emissões de GEE, quanto nos impactos ambientais de modo geral. Apesar de alguns fatores justificarem a existência de tal agrupamento $^{170}$, especialmente tendo em vista diretrizes do IPCC para elaboração de inventários de GEE no Brasil, é possível perceber que tal união acaba ocultando a discrepância ambiental existente entre as duas atividades.

Como já foi abordado anteriormente, a pecuária é a atividade humana que mais ocupa terras (ASSOCIAÇÃO BRASILEIRA DAS INDÚSTRIAS EXPORTADORAS DE CARNES, 2018; HEINRICH BÖLL FOUNDATION, 2015) e desmata no Brasil (FOOD AND AGRICULTURE ORGANIZATION OF THE UNITED NATIONS, 2016). Nos inventários de GEE brasileiros, porém, as emissões referentes à transformação de florestas em pastos acaba sendo alocada na categoria "mudanças de uso do solo", setor que apresenta o maior grau de incerteza nas estimativas nacionais (OBSERVATÓRIO DO CLIMA, 2017). Também é possível perceber que isso acaba por diluir ainda mais as emissões ligadas à produção de carne.

Todo o panorama traz consigo algumas perguntas: qual contribuição efetiva da pecuária para o aquecimento global? Como as emissões indiretas devem ser contabilizadas nas estimativas? Abordagem setoriais dos inventários de GEE acabam por dissolver a responsabilidade da indústria de produção animal em outros setores (mudanças no uso do solo)? Faz sentido a utilização de categorias como "agropecuária", que fundem em um só grupo duas atividades econômicas (agricultura e pecuária) com grande disparidade nas emissões e nos impactos ambientais?

Ainda que não haja uma relação explícita, tais questões influenciam significativamente na forma com que o vegetarianismo ambiental pode ser considerado, sobretudo se levarmos em conta o aquecimento global. Também, a discussão sobre os potenciais de redução de emissões antrópicas de GEE por meio da adoção de DBP e da redução do consumo de carne,

\footnotetext{
${ }^{170}$ Como o ponto em comum de que ambas as atividades são as principais fontes produtoras de alimentos para a humanidade, estando frequentemente associadas dentro do contexto rural (MAZOYER; ROUDART, 2010). Além disso, é preciso destacar o fato de que o termo "agriculture", em inglês (CAMBRIDGE DICTIONARY, 2018) e em francês (LAROUSSE DICTIONNAIRE, 2018), engloba a produção animal e vegetal de alimentos, não sendo, portanto, equivalente ao conceito de "agricultura" em português; ou seja, trata-se de um falso cognato.
} 
a necessidade e relevância de uma produção animal mais sustentável e a formulação de políticas públicas e ações nesse sentido, dependem do quanto o sistema-carne é considerado relevante no que diz respeito às mudanças climáticas. 


\section{VEGETARIANISMO, DIETAS BASEADAS EM PLANTAS E OUTRAS ALTERNATIVAS: POTENCIAIS, LIMITAÇÕES E CONTROVÉRSIAS}

Dentre as ações possíveis que podem contribuir para sociedades mais sustentáveis no contexto moderno, mudanças de hábitos, valores e atitudes ligadas ao consumo tem tido sua importância cada vez mais destacada (PORTILHO; CASTAÑEDA; CASTRO, 2011; QUEIROZ; GOMES; PORTILHO, 2012; ZANIRATO; ROTONDARO, 2016). Tratando-se especificamente do nosso sistema alimentar, por conta das questões ambientais envolvidas com a indústria de produção animal, particularmente no que se refere às emissões de GEE, a redução no consumo de carne, a adoção de DBP (FOX, 2000; FOX; WARD, 2008; MISHORI, 2017; PIMENTEL; PIMENTEL, 2003; SABATÉ; SORET, 2014; VINNARI; VINNARI, 2014) e até mesmo o vegetarianismo (FOX, 2000; GREIF, 2002; MISHORI, 2017; SALONEN; HELNE, 2012; SOUZA, 2017) tem sido apontados como possíveis soluções para o problema.

Apesar de DBP, redução no consumo de carne e vegetarianismo não representarem exatamente as mesmas coisas (TUSO et al., 2013), é possível compreender a correlação e as diferenças existentes entre estas ideias. Em um nível estritamente individual, a concepção do vegetarianismo realmente implica na perspectiva mais próxima da abstenção ${ }^{171}$, ou seja, de um boicote total, enquanto o conceito de DBP e a redução no consumo de carne trazem consigo uma noção mais aberta, a qual comporta a desaceleração ou moderação. No entanto, se adotamos uma escala mais ampla, considerando o aumento no número de adeptos em uma população que, majoritariamente, possui uma alimentação onívora, é possível considerar o vegetarianismo como uma forma de redução do consumo de carne total ${ }^{172}$.

Quando tratamos dos possíveis benefícios ambientais que a sociedade pode alcançar diminuindo a demanda animal, podemos, portanto, unir a discussão do vegetarianismo com a das DBP e da redução no consumo de carne, uma vez que todas estas mudanças acabam produzindo o mesmo efeito sob um ponto de vista sistêmico: a desaceleração da indústria de

\footnotetext{
${ }^{171}$ Ainda que existam dietas semi-vegetarianas, que são confundidas com as vegetarianas, a ideia de abstenção do consumo de carne costuma ser intrínseca ao conceito e à prática do vegetarianismo, como demonstrado no item 1.1 desta dissertação.

${ }^{172}$ A menos que assumamos um ponto de vista hipotético onde a população deixa totalmente de consumir carne ou produtos de origem animal de modo geral, o que consiste em um dos cenários realizados, por exemplo, no trabalho de Springmann et al. (2016).
} 
produção animal. Ademais, o fato do vegetarianismo ser uma das categorias das Dietas Baseadas em Plantas corrobora com tal união.

Por conta disso, neste capítulo, a relação entre o decrescimento no consumo de carne e a mitigação de emissões de GEE será abordada, seja pela ação do vegetarianismo ou de outras formas de redução, como as DBP. Posteriormente, as limitações, críticas e objeções específicas relacionadas a tais mudanças também são expostas, além das principais abordagens, que não envolvam abstenção ou redução do consumo de carne, para reduzir emissões de GEE da indústria de produção animal.

\subsection{Potenciais de dietas baseadas em plantas para reduzir emissões}

Sabe-se que o sistema alimentar global é um dos fatores principais que influenciam as mudanças climáticas (VERMEULEN; CAMPBELL; INGRAM, 2012). Logo, as emissões globais de GEE dependem altamente de nossos padrões alimentares (ESHEL et al., 2006; GIROD; VAN VUUREN; HERTWICH, 2014; MARLOW et al., 2009; POPP; LOTZECAMPEN; BODIRSKY, 2010; STEHFEST et al., 2009).

Evidentemente, no caso dos GEE emitidos pelo sistema-carne, estes costumam ser muito mais vinculados ao polo da produção que do consumo. Por conta deste fator, existem diversas medidas que podem ser tomadas, em múltiplas escalas e naturezas, para mitigar emissões no ciclo produtivo da carne (HERRERO et al., 2015; TOORN; BROEK; WORRELL, 2017). Além disso, maior parte dos estudos a respeito do assunto também estão focados nas reduções que podem ser feitas na cadeia produtiva, não no consumo (ROJASDOWNING et al., 2017). Entretanto, é preciso lembrar que sem demanda não há como existir produção. Logo, também é possível desacelerar os impactos da indústria de produção animal no aquecimento global por meio de mudanças nos padrões alimentares da população ${ }^{173}$ (LACOUR et al., 2018; SPRINGMANN et al., 2016).

Não apenas a FAO, mas também a OMS e diversas outras grandes organizações internacionais reconhecem a necessidade de mudar nossa alimentação por diversas razões (HEINRICH BÖLL FOUNDATION, 2015). Tendo em vista as tendências de consumo e as previsões na demanda global por carne, que pode dobrar ao longo dos próximos 30 anos,

\footnotetext{
${ }^{173}$ O termo "coprodutor", por exemplo, vem sendo utilizado para se referir aos consumidores, de modo a colocalos como parte integrante do processo produtivo e não apenas como elementos passivos (HEINRICH BÖLL FOUNDATION, 2015).
} 
(ALEXANDRATOS; BRUINSMA, 2012) além de uma população que, no ano de 2050, será composta de 9,6 bilhões de pessoas e, em 2100, de 11,2 bilhões de pessoas (UNITED NATIONS, 2017), suprir essa demanda futura de alimentos de maneira sustentável e saudáve ${ }^{174}$ representa um dos principais desafios futuros da humanidade (FOOD AND AGRICULTURE ORGANIZATION OF THE UNITED NATIONS, 2011; REGANOLD; WACHTER, 2016).

Segundo a FAO:

As dietas sustentáveis são aquelas com baixos impactos ambientais que contribuem para a segurança alimentar e nutricional e para uma vida saudável para as gerações presentes e futuras. As dietas sustentáveis são protetoras e respeitam a biodiversidade e os ecossistemas, são culturalmente aceitáveis, economicamente justas e acessíveis; nutricionalmente adequadas, seguras e saudáveis; enquanto otimiza recursos naturais e humanos (BURLINGAME, 2010, p. 7, tradução nossa).

Nesse sentido, ainda que possam haver controvérsias, principalmente relacionadas à parte econômica e cultural ${ }^{175}$, as $\mathrm{PBD}$, dentro das quais o vegetarianismo se inclui, são consideradas, de modo geral, mais sustentáveis por alguns estudos (GREIF, 2002; PIMENTEL; PIMENTEL, 2003; SABATÉ; SORET, 2014). Especificamente se considerarmos as emissões de GEE antropogênicos e, consequentemente, as mudanças climáticas, esta declaração costuma se manter (SABATÉ; SORET, 2014; SPRINGMANN et al., 2016; TILMAN; CLARK, 2014).

Tilman e Clark (2014) realizaram uma revisão de 120 trabalhos de ACV que abrangeram cerca de 82 tipos de cultivos e produtos de origem animal, permitindo comparar as emissões de diferentes tipos de dietas por quilocaloria, por grama de proteína e por porção. $\mathrm{O}$ estudo mostrou que os alimentos de origem vegetal emitem menos GEE do que os alimentos de origem animal. O gráfico apresentado na Figura 8 mostra o comparativo entre os diferentes tipos de alimentos, referentes à dieta onívora, mediterrânea, pescetariana ${ }^{176} \mathrm{e}$ vegetariana. É possível perceber que, nos três critérios de comparação utilizados, as maiores

\footnotetext{
${ }^{174}$ Ressaltando que o "saudável" não diz respeito apenas ao individual, mas ao coletivo, especialmente quando incluímos questões ambientais.

${ }^{175}$ Como a participação da pecuária na economia nacional, os empregos que a mesma gera ou ainda a importância da carne para a cultura brasileira.

${ }^{176}$ Vide Quadros 1 e 2 para definições destas dietas.
} 
quantidades de emissões estão nas carnes ${ }^{177}$, seguidas pelos derivados de leite e ovos, sendo que os alimentos que compões as PBD e a alimentação vegetariana emitem menos GEE comparativamente (TILMAN; CLARK, 2014). Existem outros estudo que corroboram essa posição (BERNERS-LEE et al., 2012; CARLSSON-KANYAMA; GONZÁLEZ, 2009; PATHAK et al., 2010).

Segundo artigo recente publicado pela revista Nature (SPRINGMANN et al., 2018), a maior parte das emissões do setor agropecuário global (entre 72 e 78\%) é atribuída à pecuária. Nesse contexto, levando em conta também as projeções de aumento na demanda futura por carne, aumento da população, dentre outros fatores, "as mudanças no consumo de carne dominam os impactos nas emissões de GEE” (SPRINGMANN et al., 2018, p.521 tradução nossa).

Para Lahsen (2017), a diminuição nas emissões de GEE através da alimentação representa uma solução "especialmente potente". Segundo a autora, reduções individuais do consumo de carne podem ser realizadas com relativa facilidade e as alternativas baseadas em plantas costumam ser, geralmente, mais adequadas nutricionalmente e mais viáveis economicamente. Já reduções de GEE através de mudanças para fontes de energia alternativas é opção que, financeiramente, é menos acessível, além de depender de esferas macro políticas e econômicas, as quais estão sob influência direta de interesses contrários. Para os pesquisadores que concordam com ess perspectiva, a sociedade de baixo carbono, portanto, pode ser melhor suportada através de mudanças na alimentação, em especial, através da carne (DE BOER; DE WITT; AIKING, 2016).

Existem ainda, outros autores, como Reisinger e Clarck (2018), que argumentam que essas medidas de mitigação nas emissões de GEE ligadas ao consumo de carne, não relacionadas diretamente ao $\mathrm{CO}_{2}$, podem representar uma importante contribuição para alcançar as rigorosas metas estabelecidas pelo Acordo de Paris.

\footnotetext{
177 É necessário destacar, novamente, a disparidade da carne de ruminantes como alimento com maior quantidade de emissões de GEE, sendo, por exemplo, 250 vezes maior do que leguminosas em comparação por grama de proteína (TILMAN; CLARK, 2014).
} 
Figura 8 - Comparativo de emissões de GEE de diferentes alimentos e dietas em função de três critérios

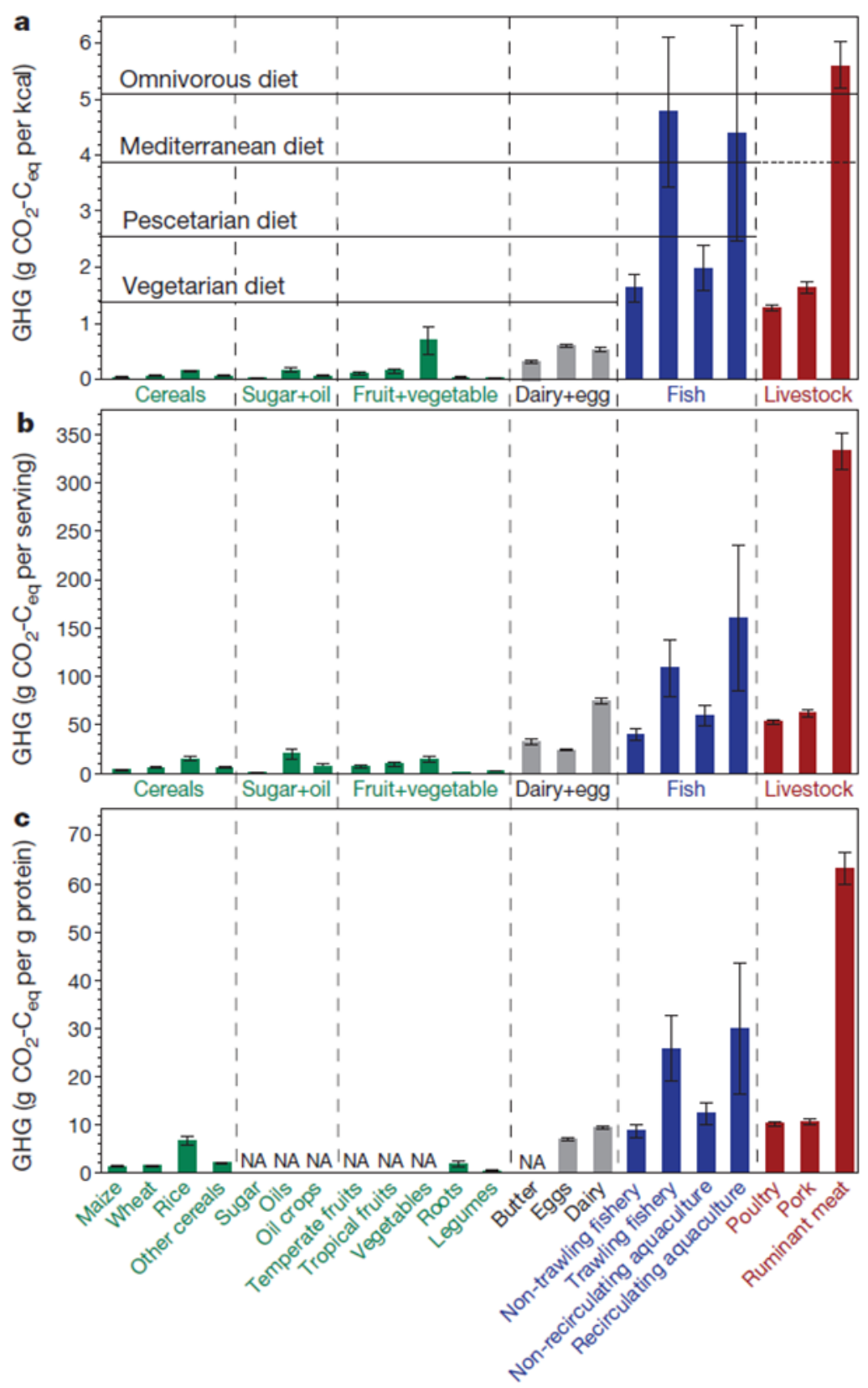

Fonte: Tilman; Clark, 2014.

Cerca de $75 \%$ das terras aráveis do planeta são utilizadas pela pecuária, direta ou indiretamente (FOLEY et al., 2011). Entretanto, a carne fornece apenas 30\% da proteína e 15\% da energia total consumida pela humanidade (HERRERO et al., 2015). As discrepâncias energéticas e ecológicas entre a produção animal e vegetal fazem com que, comparativamente, a pecuária seja menos eficiente no uso de recursos naturais. Segundo Stehfest et al. (2009), no cenário hipotético extremo de uma total eliminação dos alimentos de 
origem animal na dieta humana, seria possível suprir a demanda alimentícia da população projetada para 2050 com uma área agrícolas menor do que a utilizada atualmente, reduzindo, inclusive, as emissões globais de GEE em cerca de 7,8 Gts de $\mathrm{CO}_{2}$ eq ao ano. Já em uma projeção onde apenas a carne de ruminantes é excluída e substituída por outros alimentos, esse número reduz para 5,8 $\mathrm{GT} \mathrm{CO}_{2} \mathrm{eq}$ ao ano. Com a adoção de padrões de consumo de carne que sigam diretrizes para dietas saudáveis o número reduz para $4,3 \mathrm{Gt} \mathrm{CO}_{2} \mathrm{eq}$ ao ano (STEHFEST et al., 2009).

Além disso, ainda tratando-se da maior eficiência no uso do solo com sistemas alimentares baseados em vegetais, é preciso destacar que o tema não se limita à questão da redução nas emissões GEE, mas também envolve a viabilidade hipotética da alimentação orgânica mundial e a total eliminação da futura demanda por terras agrícolas, tudo isso simultaneamente. O estudo de Erb et al. (2016), que envolveu a projeção de 500 cenários alimentares globais, concluiu que só seria possível alimentar a população de 9,6 bilhões de pessoas de 2050, com uma produção orgânica e sem a necessidade de desmatar ou aumentar as áreas de cultivo que são utilizadas atualmente ${ }^{178}$, apenas se fossem adotados padrões alimentares vegetarianos ou $\mathrm{DBP}^{179}$ mundialmente ${ }^{180}$ (ERB et al., 2016). Outros estudos, tais como Lacour et al. (2018) e Reganold e Wachter (2016), corroboram essa relação: menores níveis de impactos ambientais na alimentação orgânica estão associados diretamente a dietas baseadas em plantas.

$\mathrm{O}$ artigo de Springman et al. (2016) também analisa o impacto de mudanças na dietas em diferentes cenários alimentares e suas consequências globais nas emissões de GEE, saúde e economia até 2050. Além de uma projeção base, que segue as tendências e padrões atuais do consumo de produtos de origem animal e que foi utilizada como padrão de comparação, os outros cenários resultantes do estudo são apresentados na Tabela 6. É notável o potencial que uma dieta que elimine o consumo alimentos derivados de animais possui: reduzir até $70 \%$ das emissões futuras de GEE associadas à alimentação, diminuir a mortalidade global em até 10\%

\footnotetext{
${ }^{178}$ Refere-se ao total de áreas ocupadas pela agropecuária mundial do momento referente aos dados de uso e ocupação do solo utilizados no estudo (ERB et al., 2016).

${ }^{179}$ Isso se deve, especialmente, pelo fato de que a pecuária orgânica, apesar de menos impactante em diversos outros aspectos, acaba demandando, comparativamente, áreas muito maiores para a produção do que sistemas intensivos de criação (SUNDRUM, 2001).

${ }^{180}$ Tal constatação endossa, parcialmente, a relação existente entre os movimentos em prol do vegetarianismo e da alimentação orgânica, citados anteriormente.
} 
e gerar uma economia global de até 1,4 trilhões de dólares por ano, tudo isso até o ano de $2050^{181}$.

Tabela 6 - Possíveis benefícios globais obtidos mudanças nos padrões de consumo de alimentos de origem animal até 2050

\begin{tabular}{|c|c|c|c|}
\hline $\begin{array}{l}\text { Cenário de } \\
\text { mudança }\end{array}$ & $\begin{array}{c}\text { Redução nas } \\
\text { emissões de GEE } \\
\text { associadas à } \\
\text { alimentação }\end{array}$ & $\begin{array}{c}\text { Redução na } \\
\text { mortalidade } \\
\text { (milhões de mortes } \\
\text { evitadas por ano) }\end{array}$ & $\begin{array}{l}\text { Economia com } \\
\text { saúde pública (em } \\
\text { dólares por ano) }\end{array}$ \\
\hline $\begin{array}{l}\text { Redução global do } \\
\text { consumo de carne } \\
\text { para padrões } \\
\text { considerados } \\
\text { saudáveis }\end{array}$ & $29 \%$ & 5,1 & 735 bilhões \\
\hline $\begin{array}{l}\text { Mudança global para } \\
\text { uma dieta } \\
\text { ovolactovegetariana }\end{array}$ & $44 \%$ até $55 \%$ & 7,3 & 973 bilhões \\
\hline $\begin{array}{l}\text { Mudança global para } \\
\text { uma dieta } \\
\text { vegetariana estrita }\end{array}$ & $63 \%$ até $70 \%$ & 8,1 & 1,067 trilhão \\
\hline
\end{tabular}

Os cenários apresentados pelos trabalhos de Stehfest et al. (2009), Erb et al. (2016) e Springmann et al. (2016) mostram potenciais muito benéficos para adoção de DBP, no que diz respeito a promover uma produção alimentar mais sustentável (o que, por si só, já deve ser levado em consideração) e apontam uma possível direção. Entretanto, para discutir a real viabilidade dos cenários propostos, seria necessário levar em conta fatores políticos, econômicos e sociais que não são contemplados por tais pesquisas.

Apesar dos diversos estudos demostrando que, de modo geral, menores taxas de consumo de carne e a priorização da produção vegetal implicaria na redução das emissões de GEE e no uso mais eficiente das terras, é preciso salientar que existem exceções para essa regra. Há locais onde a vegetação e o solo, originalmente, não são propícios para cultivos agrícolas, o que acaba fazendo que a criação de animais seja uma forma de produção de alimentos mais barata e viável (HERRERO et al., 2011). Entretanto, essas situações não são representativas do quadro geral, sendo que maior parte dos pastos ocupa áreas que poderiam

\footnotetext{
${ }^{181}$ No estudo, as emissões são calculadas em $\mathrm{CO}_{2}$ eq; a redução de mortalidade se dá, especialmente, pela diminuição de doenças crônicas ligadas as altas taxas de consumo de carne e a economia global se deve à minimização nos gastos com saúde pública e nos dias de trabalho perdidos por conta de doenças especificamente ligadas à problemática em questão (SPRINGMANN et al., 2016).
} 
ser utilizadas para fins agrícolas (GREIF, 2002) ou que, originalmente, se tratavam de florestas e foram desmatadas (FOOD AND AGRICULTURE ORGANIZATION OF THE UNITED NATIONS, 2016).

Especificamente com relação ao Brasil, não foram encontrados estudos que mostrem percentuais exatos de mitigação nas emissões de GEE nacionais que podem ser alcançadas reduzindo ou eliminando o consumo de carne. Entretanto, é possível identificar que no Brasil, por conta da forte pecuária bovina extensiva que domina o setor pecuário nacional, as emissões e impactos ambientais da indústria da produção animal são ainda mais significativos, como mostram alguns estudos (CARREIRA; RE'EM; TARIN, 2015; GUIDOTTI et al., 2015).

No ano de 2016, a agricultura brasileira produziu 25 vezes mais proteína que a pecuária, utilizando uma área 2,6 vezes menor; além disso, gerou energia suficiente para alimentar 641 milhões de pessoas enquanto a produção animal alimentou apenas 17 milhões. No mesmo ano, a produção agrícola nacional emitiu 1,4 toneladas de GEE por tonelada de proteína produzida, enquanto as emissões da pecuária foram de 220 toneladas de GEE por tonelada de proteína produzida (GUIDOTTI et al., 2015).

Além disso, é possível citar o relatório "Natural capital risk exposure of the financial sector in Brazil" (CARREIRA; RE'EM; TARIN, 2015), que expõe a disparidade de custos ambientais não inclusos no preço final da carne: para cada 1 milhão de reais em receita com pecuária extensiva bovina brasileira, geram-se, em média, 22 milhões de reais em impactos ambientais $^{182}$.

Por conta desse panorama e das constatações científicas sobre o assunto, a diminuição do consumo de animais também acaba sendo uma ação recomendada para mitigar as emissões de GEE no Brasil. Alguns estudos enfatizam a redução de carne, especialmente a bovina, na dieta brasileira como uma estratégia de mitigação (BECKER et al., 2012; COSTA, 2018; GREIF, 2002).

Medidas que procuram viabilizar a redução no consumo de carne já estão presentes na realidade brasileira, como o "Segunda sem carne"183, publicações e ações de ONGs

\footnotetext{
${ }^{182}$ No levantamento em questão, nenhuma outra atividade econômica atingiu metade do custo natural da pecuária bovina. Para dar uma noção da discrepância, o plantio de soja, atividade agrícola com finalidade alimentícia mais impactante do relatório, gerou 2,9 milhões de reais em impactos ambientais para cada milhão de reais em receita (CARREIRA; RE'EM; TARIN, 2015). Vide Tabela 3.

${ }^{183}$ Campanha da Sociedade Vegetariana Brasileira (SVB) que procura promover a substituição dos alimentos de origem animal pelos de origem vegetal no cardápio dos brasileiros uma vez por semana.
} 
vegetarianas e veganas, dentre outras $^{184}$ (AZEVEDO, 2013, 2015; NUNES, 2010). Até mesmo as recomendações vindas de órgãos governamentais são encontradas. Segundo o Guia Alimentar para a População Brasileira, produzido pelo Ministério da Saúde (MINISTÉRIO DA SAÚDE, 2014):

a diminuição da demanda por alimentos de origem animal reduz notavelmente as emissões de gases de efeito estufa (responsáveis pelo aquecimento do planeta), o desmatamento decorrente da criação de novas áreas de pastagens e o uso intenso de água (MINISTÉRIO DA SAÚDE, 2014, p. 31).

Não foram encontradas políticas públicas que tenham como objetivo abordar o problema das mudanças climáticas através de mudanças no consumo de carne no Brasil, até porque tais propostas podem esbarrar em questões delicadas. Entretanto, alguns autores, tais como Costa (2018) e Maturana (2015), argumentam que o governo deveria intervir no assunto. Para Costa (2018),

o desafio do governo brasileiro está em promover o acesso aos alimentos das famílias de menor renda direcionando as dietas primordialmente ao consumo de alimentos de origem vegetal e evitando o consumo em excesso para tornar o sistema alimentar brasileiro eficiente e menos emissor (COSTA, 2018, p. 64).

Um projeto de lei, fruto de uma parceria da SVB e entidades gestoras de restaurantes, foi vetado pelo Governador do Estado de São Paulo, em 2018. A proposta era estabelecer uma substituição compulsória da carne por outros alimentos de origem vegetal toda as segundasfeiras nos restaurantes e refeitórios de órgãos públicos (PORTAL DO GOVERNO, 2018). Outra ação similar, também promovida pela SVB, é a campanha “Opção Vegana”, iniciativa que visa auxiliar estabelecimentos que sirvam refeições a implementar ou ampliar seus pratos sem produtos de origem animal, oferecendo para os interessados consultoria gratuita e material de apoio sobre para tal (SOCIEDADE VEGETARIANA BRASILEIRA, 2018c).

Outro ponto cada vez mais discutido é a questão da taxação na produção carne e a alocação de subsídios para os alimentos de origem vegetal, principalmente tendo em vista mitigar emissões de GEE e alcançar melhorias na saúde. Segundo relatório da FAIRR (2017), (Farm Animal Investment Risk and Return) a carne está seguindo o mesmo caminho que o tabaco, ou seja, tornando-se um produto que sofrerá significativa taxação, no intuito de ter seu

${ }^{184}$ O trabalho de Laestadius et al. (2014) se dedica à análise de fatores que influenciam decisões de ONGs em realizar campanhas na redução do consumo de carne tendo em vista questões climáticas. 
consumo reduzido. De acordo com o relatório, a mudança da postura internacional para com a pecuária pode mudar significativamente, de subsidiadora para taxadora.

Entretanto, por mais que existam evidências que apontem que a carne pode se tornar um dos próximos bens sujeitos a impostos comportamentais (FARM ANIMAL INVESTMENT RISK \& RETURN, 2017), é preciso considerar diversos outros fatores que dificultariam isso no Brasil, tais como a importância da produção e consumo de carne na economia e cultura nacional (ASSOCIAÇÃO BRASILEIRA DAS INDÚSTRIAS EXPORTADORAS DE CARNES, 2018), o poder político-econômico do agronegócio no país (MICHELINI; LAHSEN, 2016), dentre outros.

O tema apresenta-se, incialmente, como uma controvérsia, uma vez que a taxação da carne, para amenizar as mudanças climáticas, pode ser considerada inevitável (THE GUARDIAN, 2017), enquanto, para outros, tal ação irá apenas prejudicar os mais pobres (NOOR, 2019).

Voltando para o tópico principal, sinteticamente, é possível perceber que há um grande potencial nas DBP e no vegetarianismo para a mitigar emissões de GEE, tanto internacionalmente quanto no Brasil. Logo, a maior parte da literatura científica estudada endossa uma redução no consumo de produtos de origem animal na dieta humana para tal finalidade $^{185}$. De modo geral, isso vai de acordo com as recomendações da UNEP (HERTWICH; VAN DER VOET; TUKKER, 2010) e do IPCC. De acordo com o AR5, mudança para DBP é uma das ações recomendadas para reduzir as emissões de GEE por meio da demanda e consumo:

\begin{abstract}
As emissões de GEE podem ser reduzidas por meio de mudanças na demanda de alimentos, sem comprometer a saúde e o bem-estar com (1) a redução as perdas e desperdícios de alimentos na cadeia de suprimentos, bem como durante o consumo final; (2) mudança das dietas para menos alimentos intensivos em GEE, por exemplo, substituição de produtos de origem animal por alimentos à base de plantas, mantendo quantitativa e qualitativamente o conteúdo proteico adequado, em regiões com alto consumo de produtos de origem animal; e (3) redução do consumo excessivo em regiões onde isso é predominante (INTERGOVERNMENTAL PANEL ON CLIMATE CHANGE, 2014b p. 838, tradução nossa).
\end{abstract}

De acordo com relatório do IPCC, uma redução no consumo de produtos de origem animal na dieta humana possui o potencial de redução de $34 \%$ até $64 \%$ das emissões de GEE

\footnotetext{
${ }^{185}$ Evidentemente, seriam necessários mais estudos e revisões bibliográficas para definir o quão alto é o grau de concordância nesse aspecto.
} 
relacionadas ao uso da terra até 2050 . No entanto, o relatório adverte que essa transição pode ser dificultada por questões diversas (SMITH et al., 2014).

Os benefícios da diminuição da carne na alimentação para as mudanças climáticas podem até superar a questão do consumo local, dependendo do contexto. De acordo com o estudo de Weber e Matthews (2008), nos EUA, a eliminação da carne vermelha da dieta em apenas um dia semana reduz mais emissões de GEE do que comprar 100\% dos alimentos de origem local $^{186}$.

É possível encontrar alguns estudos contrários a essa posição geral, como, por exemplo o trabalho de Tom, Fischbeck e Hendrickson (2016), que teve grande repercussão na mídia sob os seguintes títulos: "Dietas vegetarianas e saudáveis podem ser piores para o meio ambiente" (REA, 2015) ou "Alface é três vezes pior do que o bacon, declaram cientistas" (GOSDEN, 2015). Seguindo as comparações realizadas pelo trabalho, certos vegetais poderiam apresentar emissões até três vezes maiores do que certos tipos de carnes, o que, em grande parte, pode ser afirmado por conta das particularidades dos sistemas produtivos analisados, somado ao método de comparação utilizado no estudo: calorias. A densidade calórica de hortaliças é muito baixa quando comparada com a da carne, o que acentuaria a assimetria entre a comparação de emissões de GEE dos alimentos em questão.

Além disso, existem vegetais que são produzidos em estufas, transportados por aviões e consumidos em pontos distantes do local de produção (CARLSSON-KANYAMA; GONZÁLEZ, 2009). Nestas situações as emissões da produção vegetal se elevam e podem até superar as das carnes.

Apesar de sua grande repercussão na mídia, tais casos que colocam os vegetais acima das carnes em termos de emissões, representam exceções ${ }^{187}$, uma vez que diversos outros estudos corroboram o potencial hipotético de mitigação de emissões através de mudanças na dieta, especialmente com relação à carne (BAJŽELJ et al., 2014; BERNERS-LEE et al., 2012; GREEN et al., 2015; HEDENUS; WIRSENIUS; JOHANSSON, 2014; POPP; LOTZECAMPEN; BODIRSKY, 2010; SMITH et al., 2013).

\footnotetext{
${ }^{186}$ É preciso ressaltar, no entanto, que o estudo diz respeito à realidade norte americana e não leva em conta muitos outros benefícios culturais, econômicos e sociais do locavorismo, focando apenas na questão das mudanças climáticas.

${ }^{187}$ O trabalho de Carlsson-Kanayama e Gonzales (2009) aborda alguns exemplos de tais exceções.
} 
A maior parte dos estudos existentes, entretanto, são baseados em mudanças hipotéticas $^{188}$. Sabe-se relativamente pouco sobre a real eficácia e alcance de mudanças nos sistemas alimentares e no consumo de carne (HERRERO et al., 2015). Nesse sentido, apesar dos estudos mostrarem que é possível reduzir significativamente as emissões de GEE mudando as taxas de consumo carne, críticas, limitações e incertezas podem ser levantadas e a real viabilidade dessa mudança pode ser colocada em questão.

\subsubsection{Limitações e críticas: da importância e cultura da carne ao poder do agronegócio}

Apesar de uma concordância indentificada sobre os potenciais benefícios de se reduzir o consumo de carne como forma de mitigar emissões de GEE, a discussão sobre mudanças na dieta da população acaba sendo algo muito mais sensível por diversos fatores. Nesse sentido, algumas questões precisam ser destacadas.

Levando em conta a prevalência da fome, desnutrição e insegurança alimentar em diversos locais do mundo, é preciso ter cuidado ao tentar interferir em padrões alimentares. Em alguns casos específicos, discutir a redução de alimentos de origem animal pode colocar em risco a nutrição (GODFRAY et al., 2010; INTERGOVERNMENTAL PANEL ON CLIMATE CHANGE, 2014b) e, além disso, envolve alguns fatores econômicos, culturais e de saúde pública (HEINRICH BÖLL FOUNDATION, 2015).

Em diversas regiões do mundo, o gado utilizado para produzir carne é alimentado com plantas que não são adequadas para o consumo humano ou que são cultivadas em terras inapropriadas para cultivos agrícolas, as quais possuem altos estoques de carbono. Nestes contextos, a produção de alimentos por animais em pastoreio contribui significativamente para a segurança alimentar (GILL; SMITH; WILKINSON, 2009; INTERGOVERNMENTAL PANEL ON CLIMATE CHANGE, 2014b; WIRSENIUS, 2003).

Também é preciso enfatizar que os potenciais benefícios ambientais da redução no consumo de carnes dizem respeito, sobretudo, ao nosso contexto de consumo moderno, que é suprido por lógicas industriais de produção em massa. A pesca de subsistência, desenvolvida por algumas populações ribeirinhas (SANTOS; SANTOS, 2005), a caça de subsistência, praticada por certos povos indígenas na Amazônia (PIMENTA, 2004), além de outras lógicas

${ }^{188}$ Por isso, justamente, tratamos de "potenciais" neste subcapítulo. 
em que o consumo de animais é realizado localmente (AZEVEDO, 2015) em taxas muito reduzidas estão entre os exemplos em que a perspectiva do vegetarianismo ambiental, ou a ideia mais geral da necessidade de reduzir a carne visando benefícios socioambientais, não faz tanto sentido.

Especialmente no contexto de uma sociedade industrial de consumo em massa, as consequências da forma com que nos alimentamos extrapola a esfera pessoal. Nesse sentido, a carne possui um destaque especial como um dos elementos da dieta humana que mais amplia impactos ambientais em diversas escalas (FOOD AND AGRICULTURE ORGANIZATION OF THE UNITED NATIONS, 2006). Apesar disso, a comida é, também, um assunto muito pessoal (AZEVEDO, 2013), que envolve questões como familiaridade, pertencimento, rotina, relaxamento (HEINRICH BÖLL FOUNDATION, 2015) e, até mesmo, afetividade (TAVARES, 2018).

A redução no consumo de animais torna-se mais complexa se consideramos que a carne é um dos alimentos mais consumidos no Brasil (SOUZA et al., 2013), com grande importância em nossa cultura alimentar, sendo o "ritual do churrasco"189 o exemplo mais proeminente desta relação. Trata-se, portanto, de um hábito profundamente enraizado, que extrapola o aspecto puramente alimentar e compõe parte da identidade cultural em algumas regiões, como é o caso emblemático da cultura gaúcha (HEINRICH BÖLL FOUNDATION, 2015; RIBEIRO; CORÇÃO, 2013; SORDI, 2013).

Sendo assim, há uma diversidade de produtos de origem vegetal que são colocados como substitutos, não apenas no seu aspecto nutricional ${ }^{190}$, mas, em características que cumprem outras funções. O "churrasco vegano", por exemplo, muitas vezes é feito com preparados vegetais fibrosos, cuja textura se assemelha à carne quando assados. Entretanto, existem fortes críticas com relação à aceitação de tais substitutos ${ }^{191}$ (SORDI, 2013), especialmente se levamos em conta o status de "alimento absoluto" que a carne possui para a

\footnotetext{
${ }^{189}$ Maciel (1996) aborda a perspectiva ritualística do churrasco.

${ }^{190}$ Muitos dos alimentos de origem vegetal que são apontados como substitutos da carne adquirem este status por conta de sua alta densidade protéica, uma vez que essa é uma das principais características nutricionais atribuídas à carne (ROÇA, 2011).

${ }^{191}$ O churrasco vegetariano, ou seja, sem a presença da carne de origem animal, pode ser considerada por muitos como uma perda de autenticidade. Entretanto, se observarmos o modo dinâmico que a culinária se desenvolve historicamente, essa postura essencialista não possui respaldo (ALTOÉ, 2017). Além disso, o sabor também é relevante, uma vez que, especialmente dentro de movimentos mais recentes de valorização da carne, existe um discurso sobre o "sabor superior" da carne, colocando-a, portanto, como algo insubstituível do ponto de vista gastronômico (PARRY, 2010).
} 
estilo de vida ocidental moderno (FISCHLER, 1990), além de todos os outros fatores que lhe agregam importância. É possível observar, ainda, a estreita dependência que os corpos de muitos possuem para com a carne, seja ela física, cultural, psíquica ou de outra natureza.

É necessário também enunciar algumas questões políticas, econômicas e midiáticas que são estruturais em toda a problemática. O trabalho de Lahsen (2017) revisou a cobertura dos jornais brasileiros sobre a relação entre carne e mudanças climáticas e identificou tendências ligadas ao silêncio e à minimização do problema. Segundo a autora, embora a pecuária configure a maior fonte de emissões de GEE no Brasil ${ }^{192}$, apenas $0,14 \%$ dos artigos jornalísticos revisados que tratavam de mudanças climáticas relacionavam carne e clima. $\mathrm{Ou}$ seja, apesar da importância, o tema possui sua atenção reduzida e é ainda mais subdesenvolvido na mídia brasileira do que em países como os EUA, Espanha, Itália e no Reino Unido ${ }^{193}$. São fornecidas algumas explicações políticas e econômicas preliminares para tal situação:

\begin{abstract}
Dadas essas forças formidáveis em favor de uma ênfase contínua na produção de carne, apesar de suas consequências desastrosas, a mídia é especialmente necessária como uma força para fazer intervenções em normas e modos de pensar dominantes. Numerosos relatórios recentes (OPEN SOCIETY INSTITUTE, 2008; REPORTERS WITHOUT BORDERS, 2013) identificam um forte mecanismo de controle operando através da mídia latino-americana e que serve interesses de elites e de negócios. Esses mecanismos incluem elementos repressivos dos períodos da ditadura que permaneceram em vários lugares ou se transformaram em meios mais sutis de censura e controle (LAHSEN, 2017, p. 31, tradução nossa).
\end{abstract}

Sobre tal relação com a mídia a autora detalha:

\begin{abstract}
Os governos da região também abusam de seus poderes financeiros e regulatórios sobre a mídia, por exemplo, usando fundos de publicidade e processos de licenciamento dos quais a mídia depende para sua sobrevivência, para recompensálos ou puni-los. No Brasil, a distinção entre o formidável lobby agrícola do país e seu governo é turva (MACHADO, 2013), e uma parte considerável dos políticos eleitos do país - muitos deles parte do lobby do agronegócio - também são donos de mídia, apesar de proibições constitucionais contra isso (LAHSEN, 2017, p. 31, tradução nossa).
\end{abstract}

É de se esperar, portanto, o desconhecimento da população sobre o assunto, o que pode dificultar ainda mais as mudanças no consumo de carne. Existem iniciativas, entretanto,

\footnotetext{
192 Realidade não compartilhada por outros países.

${ }^{193}$ Sendo que, neste países o tema também possui uma atenção minimizada na cobertura jornalística.
} 
que procuram reverter esse quadro. Em 2014 foi lançado o documentário "Cowspiracy: the sustainability secret" (COWSPIRACY, 2014), que realiza uma denúncia ao apresentar evidências de que grandes ONGs ambientalistas estariam recebendo doações das empresas responsáveis pela pecuária industrial para que suas campanhas ignorassem a responsabilidade da indústria de produção animal nas problemáticas ambientais atuais. Apesar das polêmicas e conflitos gerados, especialmente entre ativistas e ONG's de proteção ambiental, o documentário recebeu diversos prêmios em categorias de cinema focados em meio ambiente. Em um trecho do documentário, o jornalista, ativista e autor Michael Pollan comenta o silêncio das organizações ambientais sobre o problema da carne:

Porque essas organizações tem sócios, entende? Muitas delas. Eles tentam maximizar o número de pessoas que fazem doações. E se eles forem taxados de anticarne ou afrontarem os hábitos diários das pessoas (...) isso vai diminuir o financiamento (COWSPIRACY, 2014, 15min56s, tradução nossa).

O escritor ativista, educador e autor Will Tuttle endossa:

\begin{abstract}
Eles não querem atacar a principal força motriz da devastação ambiental, que é a agricultura animal (pecuária) por causa dos negócios. E eles querem se assegurar de ter uma fonte confiável de financiamento (...). É como quando temos uma família problemática e o pai é um alcoólatra, o que é uma coisa que ninguém pode comentar. Todo mundo desvia do assunto e mesmo assim ele é a principal causa da destruição dos relacionamentos familiares, porque ninguém quer falar sobre isso (COWSPIRACY, 2014, 16min12s, tradução nossa).
\end{abstract}

Paralelamente a toda essa exposição recente dos impactos da pecuária, no Brasil, em 2018, foi lançado o documentário ${ }^{194}$ "Sob a pata do boi” (SÁ, 2018). Apesar de não focar na questão das emissões de GEE, o documentário expõe toda a íntima relação existente entre a pecuária bovina e o desmatamento da Amazônia. Além disso, trabalhos e campanhas de ativistas e grupos vegetarianos, como a publicação "Comendo o Planeta" (SCHUCK; RIBEIRO, 2015), relatório desenvolvido pela Sociedade Vegetariana Brasileira (SVB) que se baseia em conhecimento científico moderno para mostrar os impactos ambientais da pecuária em diversos aspectos, bem como reportagens em grandes veículos de mídia ${ }^{195}$, dentre outras

\footnotetext{
194 Também premiado internacionalmente.

195 Como, por exemplo, a reportagem publicada pela BBC (British Broadcasting Corporation) em 2016, intitulada "O que aconteceria se o mundo inteiro virasse vegetariano?" (NUWER, 2016), a qual cita o artigo científico de Springmann (2016) e de outros especialistas.
} 
ações, estão informando a população sobre a relação entre pecuária e os problemas socioambientais modernos. A própria procura pelo vegetarianismo ambiental e pelos benefícios que a redução de carne pode trazer nesse sentido, estão sendo cada vez mais pesquisados na internet e discutidos online (CAPUTO et al., 2012).

É possível reconhecer dentro das "guerras da carne" (LEWGOY; SORDI, 2012), que as questões ambientais tem sido um ponto de intensa disputa em crescimento. Mudanças nos padrões de consumo de carne também dependem do conhecimento da população sobre o assunto, além de esbarrar nas forças políticas e econômicas que o agronegócio possui no Brasil (LAHSEN, 2017).

No entanto, tais forças atuantes não possuem sua origem restrita à corrupção dos governos e mídias latino-americanos, pois. De acordo com o estudo de Galaz et al. (2018), $68 \%$ de todo o capital estrangeiro ${ }^{196}$ de nove grandes empresas de soja e carne que atuam na Amazônia, foi transferido através de paraísos fiscais. Essa evidência expõe parte da influência internacional em toda problemática.

É preciso salientar que, muito além de interesses políticos, econômicos e supostas manipulações midiáticas de actantes com grandes poderes, soma-se o fato de que todo o sistema-carne se enraíza em diversos outros aspectos e dependências de nossa sociedade brasileira moderna (SORDI, 2013). Logo, desengajar-se de tudo isso é uma atitude duplamente difícil, a qual vai muito além de uma simples "escolha alimentar".

Tendo em vista a necessidade urgente que nosso país possui na adoção de medidas de mitigação das emissões de GEE, a ausência de estudos nacionais que relacionem mudanças nas dietas com possíveis reduções de GEE são escassos. Esse desconhecimento, somado a toda a minimização do problema em outras esferas acaba por gerar ainda mais incertezas na formulação de políticas públicas que visem mitigar emissões sem comprometer a saúde pública e a segurança alimentar e nutricional (COSTA, 2018).

Existem ainda questões macro e microeconômicas que influenciam no assunto. Deixando de lado a concepção equivocada de que o vegetarianismo é uma opção elitista ${ }^{197}$

\footnotetext{
196 Trata-se do capital estrangeiro (26,9 bilhões de dólares) investigado, recebido por nove grandes empresas nos setores da soja e carne bovina do Brasil, dentre elas: Bertin, JBS, Marfrig e Minerva (PÁGINA 22, 2018).

${ }^{197}$ Como no discurso do diretor de sustentabilidade da ABIEC, na ocasião do Congresso Internacional da Carne em 2011, que coloca o vegetarianismo como "coisa de elitista" (SORDI, 2013).
} 
somente acessível quando se possui uma renda mais elevada ${ }^{198}$, quando tratamos de populações com poder aquisitivo menor é essencial proteger o acesso das mesmas a uma alimentação variada e sadia. Nesse sentido, interferências ou impedimentos no consumo de proteínas animais pode acabar sendo algo problemático, tendo em vista pessoas com dietas já limitadas por fatores econômicos e sociais, o que não ocorre tanto com classes com um alto poder aquisitivo (HEINRICH BÖLL FOUNDATION, 2015).

Constantemente a importância econômica da indústria de produção animal também é destacada, não apenas por sua participação no PIB brasileiro (ASSOCIAÇÃO BRASILEIRA DAS INDÚSTRIAS EXPORTADORAS DE CARNES, 2018), mas pelo fato de que a cadeia de carne bovina mantém cerca de 7 milhões de empregos (INSTITUTO DE MANEJO E CERTIFI CAÇÃO FLORESTAL E AGRÍCOLA, 2015), além da agropecuária ser uma atividade estrutural para a economia de diversos municípios do país (INSTITUTO BRASILEIRO DE GEOGRAFIA E ESTATÍSTICA, 2015).

Entretanto, tal importância econômica é rigidamente confrontada quando os elevados custos de externalidades socioambientais são inclusos nas equações econômicas (CARREIRA; RE'EM; TARIN, 2015). Nesse sentido, portanto, existem aqueles que declaram que o decrescimento no consumo é um caminho desejável (SCHUCK; RIBEIRO, 2015), enquanto outros propõem que as mudanças tecnológicas seriam suficientes para dar conta da parte ambiental do problema, como será melhor abordado no item 4.2. De fato, sejam quais forem as soluções é necessário levar a dimensão econômica em conta, especialmente em um país com significativa exportação de carne e expressiva produção agropecuária, como é o caso do Brasil.

A influência de mudanças no consumo de carne na economia depende de diversas outras questões. O estudo de Lock et al. (2010), utilizou modelagem de sistemas complexos para estimar os efeitos na economia em uma transição alimentar para padrões de dietas com o consumo de carne reduzido. No Brasil, por exemplo, com uma redução hipotética de 33\% do consumo doméstico de alimentos de origem animal em geral, estimou-se um efeito positivo de 22 milhões de reais no PIB. Por outro lado, caso haja uma redução de 18\% no consumo

\footnotetext{
${ }^{198}$ Tal ideia pode ser sido originada pelo fato de que a adoção do vegetarianismo e do veganismo são associadas à um maior poder aquisitivo (MEDEIROS, 2017; RUBY, 2012). Logo, há um nicho de mercado que paga mais caro por produtos especializados, os quais são produzidos em menor escala e que possuem, muitas vezes, ingredientes integrais e orgânicos em sua formulação (QUEIROZ; SOLIGUETTI; MORETTI, 2018). Entretanto, refeições vegetarianas nutricionalmente adequadas e equivalentes aquelas com carne, produzidas com ingredientes simples, não implicam em custos necessariamente mais elevados (LOBATO et al., 2016).
} 
doméstico de carne, estima-se um efeito negativo de 50 milhões no PIB. São constatações interessantes e que mostram, portanto, que precisar exatamente os efeitos econômicos na adoção de DBP (LOCK, 2010) é um processo complexo e dinâmico.

Outro ponto importante a ser ressaltado é que, ainda que a carne esteja associada a maiores emissões de GEE de modo geral, certos alimentos de origem vegetal também podem ter impactos ambientais bem elevados, dependendo de alguns fatores. Ainda que não representem uma grande parcela da produção vegetal e tratem-se de casos específicos, alguns vegetais cultivados em estufas, transportados por grandes distâncias podem se equiparar ou, até mesmo, superar as emissões das carnes (TOM; FISCHBECK; HENDRICKSON, 2015).

$\mathrm{O}$ aumento da demanda por quinoa por diversos consumidores do mundo ${ }^{199}$, por exemplo, acabou impactando o mercado nos locais da produção, transformando um alimento tradicionalmente consumido pelas populações mais pobres do Peru e da Bolívia em um produto inacessível para as mesmas (AZEVEDO, 2015).

Por mais benefícios hipotéticos que as DBP possam trazer para a sustentabilidade e segurança alimentar e por mais que, se analisarmos todo o conhecimento compilado por este trabalho, seja possível perceber que as produções animais e vegetais possuem discrepâncias ecológicas e energéticas basais, é necessário considerar que a produção vegetal também pode ser significativamente impactante. Logo, é preciso atenção no que se refere às dinâmicas de produção, transporte, armazenamento e consumo destes alimentos.

Resta ainda, questionar a eficácia dos discursos, políticas e ações que visam a redução do consumo de carne visando critérios de saúde e sustentabilidade. A maior parte das análises realizadas possuem pouca consideração às restrições e preferências dos consumidores que, em muitos casos, tendem a ser bem conservadoras com relação a mudanças (HERRERO et al., 2015).

O artigo de Vinnari e Vinnari (2014) cita algumas das principais medidas de governança, estratégicas, táticas e operacionais, que têm sido sugeridas e realizadas em outros países, visando uma transição sustentável para DBP, além dos principais obstáculos enfrentados para tal. O Quadro 4 traz alguns destes obstáculos que podem prejudicar transições para DBP. Ainda que seja possível questionar algumas das formas de categorizar

\footnotetext{
${ }^{199}$ Destaca-se a aceitação da quinoa pelos consumidores que procuravam alimentos para dietas saudáveis e vegetarianas (AZEVEDO, 2015).
} 
tais obstáculos no quadro em questão ${ }^{200}$, é interessante observar a diversidade de fatores que podem ser elencados.

Quadro 4 - Possíveis obstáculos e limitações na transição para dietas baseadas em plantas

\begin{tabular}{|c|c|}
\hline Dimensão & Obstáculos e limitações \\
\hline \multirow[t]{4}{*}{ Social } & $\begin{array}{l}\text { Saúde humana: crença na necessidade nutricional de alimentos de origem } \\
\text { animal em uma alimentação saudável }\end{array}$ \\
\hline & $\begin{array}{l}\text { Participação: algumas pessoas não estão integradas ao sistema agropecuário } \\
\text { moderno }(1)\end{array}$ \\
\hline & $\begin{array}{l}\text { Empoderamento: estruturas institucionais atuais capacitam as pessoas a } \\
\text { consumirem carne }\end{array}$ \\
\hline & $\begin{array}{l}\text { Coesão social: atual coesão social em torno da carne, sendo a mesma } \\
\text { considerada como um alimento mais saboroso ou nobre }\end{array}$ \\
\hline \multirow[t]{3}{*}{ Econômico } & $\begin{array}{l}\text { Equidade: a perspectiva de que os produtores têm o direito de ganhar à } \\
\text { medida que investiram no atual sistema de produção de alimentos }\end{array}$ \\
\hline & $\begin{array}{l}\text { Eficiência: crença na excelência e eficiência do moderno sistema de } \\
\text { produção de alimentos }\end{array}$ \\
\hline & $\begin{array}{l}\text { Desenvolvimento: preocupação com o bem-estar econômico dos produtores e } \\
\text { atores da agroindústria }\end{array}$ \\
\hline \multirow[t]{3}{*}{ Ambiental } & $\begin{array}{l}\text { Biodiversidade: desconhecimento da ligação entre o consumo de alimentos e } \\
\text { a pressão resultante sobre o meio ambiente, que reduz a biodiversidade }\end{array}$ \\
\hline & $\begin{array}{l}\text { Capacidade de carga: desconhecimento da ligação entre consumo de } \\
\text { alimentos e mudança climática; por exemplo, perturbação do ciclo de } \\
\text { nitrogênio ou restrições de água doce }\end{array}$ \\
\hline & $\begin{array}{l}\text { Abordar questões globais: a falta de interesse dos consumidores e atores do } \\
\text { setor público e privado como questões ambientais ainda não influenciam a } \\
\text { vida diária da maioria das pessoas }\end{array}$ \\
\hline \multirow[t]{3}{*}{ Cultural } & $\begin{array}{l}\text { Identidade cultural: importância do consumo de carne para a identidade } \\
\text { cultural, ou seja, a separação entre humanos e animais }\end{array}$ \\
\hline & $\begin{array}{l}\text { Mantendo as tradições: a facilidade de continuar os hábitos atuais, a falta de } \\
\text { conhecimento sobre a produção moderna de alimentos e as falsas crenças } \\
\text { sobre nossas dietas históricas }\end{array}$ \\
\hline & $\begin{array}{l}\text { Aderir às normas culturais: disposição para obedecer a normas culturalmente } \\
\text { determinadas para evitar a reclusão. Ou seja, comer o que os outros comem }\end{array}$ \\
\hline \multirow[t]{2}{*}{ Animal } & $\begin{array}{l}\text { Bem-estar animal: os seres humanos consideram que possuem atributos } \\
\text { supremos em comparação com outros animais ou desconsideram os atributos } \\
\text { de outros animais }\end{array}$ \\
\hline & $\begin{array}{l}\text { Direitos dos animais: os humanos não se consideram animais de todo devido, } \\
\text { por exemplo, a crenças religiosas }\end{array}$ \\
\hline
\end{tabular}

Fonte: Traduzido e adaptado de Vinnari; Vinnari, 2014.

${ }^{(1)}$ Logo, não faz sentido lhes cobrar mudanças para solucionar problemas causados por tais sistemas.

${ }^{200}$ Como, por exemplo, as separações feitas entre o social e o cultural, que se confundem. 
Evidentemente, não é possível aprofundar em todos os obstáculos existentes, tampouco localizá-los e repensá-los na realidade brasileira. Entretanto, tendo em vista a complexidade da questão, futuros estudos poderiam analisar melhor as limitações, obstáculos bem como os custos administrativos e sociais que uma transição para DBP pode gerar no país.

Finalmente, é necessário estabelecer que, havendo ou não mudanças na dieta da população, é preciso que ela tenha acesso à informação científica que seja representativa sobre a relação entre pecuária e emissões de GEE. Assim, portanto, será mais fácil discutir e exigir as políticas necessárias para as mudanças nos nossos sistemas alimentares, estejam elas focadas na produção, mercado ou consumo.

Também faz-se clara a importância da não imposição do vegetarianismo ou das DBP, bem como de afastar os julgamentos morais ou discriminações ao consumo de carne (AZEVEDO, 2013). Deve-se respeitar, portanto, a diversidade alimentar e levar em conta as importâncias que a produção e consumo de carne possui para muitos, sem deixar, obviamente, de reconhecer e encarar os seus significativos impactos socioambientais, especialmente no que diz respeito das emissões de GEE no Brasil.

Deve-se, portanto, reconhecer que, tal qual os critérios que definem uma dieta sustentável, de acordo com a FAO (BURLINGAME, 2010), as formas de alimentação que propõem reduzir o consumo de carne, sejam as DBP ou vegetarianismo, também devem levar em conta aceitação cultural, acessibilidade e serem economicamente justas.

Considerar todos estes fatores citados neste item não significa se render à um conservadorismo ou preciosismo no consumo de carne, até porque, obviamente, sabemos que sem aceitar que são necessárias mudanças, seja lá quais estas forem, qualquer perspectiva de progresso para uma sociedade mais sustentável se perde. Trata-se, na verdade, de reconhecer, por um lado resistências para a adoção das DBP e, por outro lado, compreender as importantes questões e elementos que devem ser levados em conta em toda a discussão.

\subsubsection{Abstenção ou redução?}

Como já foi explicado anteriormente, DBP é um conceito consideravelmente mais abrangente, que engloba desde o vegetarianismo até dietas semi-vegetarianas. Sob um ponto de vista macro, o crescimento do vegetarianismo em uma população que come carne pode significar uma redução no consumo total de animais, tendo em vista os fluxos de matéria e 
energia envolvidos nos processos de produção e consumo. No entanto, é preciso reconhecer que, especialmente em um nível individual, discutir a possibilidade da abstenção total ou da redução são coisas consideravelmente diferentes, com implicações distintas.

Por um lado, perspectivas que trazem a ideia de redução do consumo, seja da carne ou de produtos de origem animal de modo geral, são tidas como menos radicais e, portanto, mais acessíveis. Diversos consumidores ao redor do planeta optaram por abordagens que estão mais relacionadas com a dimensão e velocidade, dois fatores que são estruturais para a forma impactante com que a indústria de produção animal tem-se desenvolvido (HEINRICH BÖLL FOUNDATION, 2015).

Dada a forma com que o sistema-carne se configura, principalmente em um país como o Brasil, as ideias vegetarianas e veganas acabam esbarrando em uma resistência maior do que as visões reducitarianistas, correndo o risco de antagonizar e excluir os que não concordam com essa visão (MISHORI, 2017) e, até mesmo, de se tornar algo dogmático e sentencioso $^{201}$ (MARRAS, 2014). É possível que, por conta de sua maior acessibilidade e disseminação no tecido social, o comedido discurso da moderação seja mais ameaçador para a indústria de produção animal, até porque isso não vai contra as próprias indicações dos especialistas e cientistas que defendem o consumo de carne na dieta humana, uma vez que os mesmos frequentemente pontuam a importância da moderação em algum grau (SORDI, 2013).

O flexitaritarianismo, reducitarianismo e dietas semi-vegetarianas de modo geral estão sendo cada vez mais recomendadas como uma das soluções para o "trilema" dieta-ambientesaúde (BRIAN, 2017; TILMAN; CLARK, 2014). As recomendações sobre o que objetivamente seria essa "moderação da carne" variam. Alguns estudos que visam estabelecer limites sustentáveis nas taxas de consumo recomendam um máximo semanal de aproximadamente 500g (EATING BETTER, 2018); também há aqueles que aconselham retirá-la do cardápio pelo menos uma vez por semana; ainda outros sugerem reduzir o tamanho das porções de alimentos de origem animal (DE BOER; SCHÖSLER; AIKING, 2014). É possível encontrar, até mesmo, declarações de que precisamos reduzir a ingestão

\footnotetext{
${ }^{201}$ Existem pesquisas como as de Monin (2007) e Minson e Monin (2012) que abordam julgamentos morais feitos entre vegetarianos e não vegetarianos. Neste ponto é preciso enunciar ainda que, da mesma forma que o vegetarianismo corre o risco de levar à uma postura dogmática ou fundamentalista, a defesa do consumo de carne também pode incorrer em posturas similarmente intolerantes. O próprio conceito do "carnismo", explorado por Joy (2010) explicita bem essa ideia de uma visão do "comer carne" que é baseada em uma inquestionabilidade e, até mesmo, em preconceitos. É portanto, um risco em comum entre os dois lados.
} 
para até cerca de 60 gramas por semana ${ }^{202}$ (COWSPIRACY, 2014). É possível expressar a necessidade de estudos que estipulem possíveis quantidades específicas de redução, dadas as condições nutricionais, limitações culturais e sociais de mudanças na dieta e especificidades do sistema alimentar brasileiro.

Apesar da maior aceitabilidade das perspectivas de redução da carne, houve um notável crescimento do vegetarianismo em diversos locais do mundo nas últimas décadas, incluindo o Brasil. O alcance máximo que a adoção de dietas que eliminam totalmente alimentos de origem animal em nossa população ainda é incerto. No entanto, é preciso ressaltar que, apesar de serem consideradas menos populares e mais radicais por muitos, essas posturas de abstenção também apresentam alguns apelos exclusivos, o que pode ser um fator que contribui para dar mais força às mudanças individuais.

Tanto a prática de um vegetarianismo estrito baseado no princípio do abolicionismo animal, quanto o próprio veganismo, que está necessariamente ligado às questões éticas, partem do princípio de que o consumo de carne, em qualquer quantidade, seria errado. Essa ideia, para muitos adeptos de dietas vegetarianas, é o fator central que permite uma transição significativa na dieta e no estilo de vida (BRÜGGER, 2009; FRANCIONE, 2008; NUNES, 2010; QUEIROZ; SOLIGUETTI; MORETTI, 2018). Logo, em diversos casos, mudanças na alimentação só foram fomentadas e possíveis através da perspectiva da abstenção. Ou seja, o "parar totalmente" também pode ser importante para muitas pessoas, seja por representar para estes a "única forma" de praticar certos princípios éticos ${ }^{203}$ ou por ser uma maneira mais simplista de estabelecer restrições ${ }^{204}$.

Além disso, é possível citar o fato de que, generalizadamente, a redução das emissões de GEE é mais significativa com a eliminação total da carne do que com uma redução parcial (SPRINGMANN et al., 2016; TILMAN; CLARK, 2014). De acordo com o gráfico apresentado na Figura 8, além dos demais estudos citados, outros derivados animais, além da carne, também costumam ter um impacto mais elevado do que as opções de origem vegetal,

\footnotetext{
${ }^{202}$ Opinião do jornalista, ativista e autor de diversos livros sobre alimentação, Michael Pollan, expressada no documentário Cowspirancy (2014).

${ }^{203}$ Alguns exemplos podem ser encontrados no trabalho de Nunes (2010). É preciso deixar evidente que essa dinâmica de total abstenção não torna mudanças alimentares individuais necessariamente mais resilientes, duradoras ou desejáveis para todos. Trata-se, apenas, de um ponto essencial para muitos.

${ }^{204}$ Nesse sentido é possível tomar o exemplo de pessoas que preferem mudar hábitos alimentares o fazendo de forma abrupta, simplesmente eliminando o que pretendem deixar de consumir. É preciso ressaltar, no entanto, que, de modo geral, as transições para vegetarianismo feitas de forma gradual são consideradas mais fáceis e menos problemáticas (SOCIETÀ SCIENTIFICA DI NUTRIZIONE VEGETARIANA, 2018).
} 
no que diz respeito a emissões de GEE. Logo, a opção pessoal de se abster destes produtos pode somar ainda mais à mitigação das mudanças climáticas. Estes são exemplos de fatores que podem agregar importância às tomadas de decisões individuais ligadas à abstenção total.

Levando em conta os pontos ressaltados anteriormente, os quais podem influenciar na aceitação da redução ou da abstenção do consumo de carne, talvez seja possível afirmar que a DBP seja de fato uma categoria adequada para recomendações, uma vez que ela permite a liberdade de escolha entre um boicote total ou diversos graus de moderação, ao mesmo tempo que deixa claro qual a direção da mudança necessária em nossa alimentação: menos animais, mais plantas.

\subsection{Outras alternativas}

Nem todas as possíveis soluções para reduzir as emissões de GEE na nossa alimentação estão ligadas à redução ou abstenção do consumo de alimentos de origem animal. Muito pelo contrário: existem numerosas alternativas para promover uma pecuária sustentável, novas tecnologias de produção de carne menos impactantes e, até mesmo, o consumo seletivo de certas espécies de animais, estão entre as opções que também podem contribuir para uma alimentação mais sustentável e que, portanto, devem ser levadas em conta em todo o debate.

\subsubsection{Pecuária sustentável: potenciais e problemas}

Devido à disparidade energética existente entre a produção animal e vegetal, a produção de alimentos de origem animal costuma emitir uma quantidade maior de GEE que alimentos de origem vegetal, comparativamente. A produção de $1 \mathrm{~kg}$ de carne bovina brasileira pode chegar uma possuir pegada de carbono ${ }^{205}$ de até $726 \mathrm{~kg}$ de $\mathrm{CO}_{2} \mathrm{eq}^{206}$ (CEDERBERG et al., 2011), enquanto os valores médios da produção de $1 \mathrm{~kg}$ de substitutos de origem vegetal estão entre 1 ou 2 kg de $\mathrm{CO}_{2}$ eq (NIJDAM; ROOD; WESTHOEK, 2012).

\footnotetext{
${ }^{205}$ Estimativas de emissões de GEE envolvidas com o ciclo de vida de um determinado produto (CEDERBERG et al., 2011).

${ }^{206}$ No caso, carne bovina brasileira produzida em área desmatada (CEDERBERG et al., 2011).
} 
Os números são significativos e corroboram os potenciais que mudanças nos padrões de consumo de carne possuem para mitigar as mudanças climáticas.

Quadro 5 - Estratégias de mitigação das emissões da pecuária ligadas aos processos produtivos

\begin{tabular}{|c|c|}
\hline Estratégia de mitigação & Ações possíveis \\
\hline Sequestro de carbono & $\begin{array}{l}\text { Plantio de árvores e medidas de } \\
\text { compensação do carbono emitido }\end{array}$ \\
\hline Minimizar fermentação entérica & $\begin{array}{l}\text { Aumentar o teor de gordura e proteína na } \\
\text { dieta dos animais, melhoria da qualidade da } \\
\text { forragem, uso de suplementos, uso de } \\
\text { antimetanogênicos (vacinas que suprimem } \\
\text { as emissões de metano) }\end{array}$ \\
\hline Gestão do estrume & $\begin{array}{l}\text { Encurtar a duração do armazenamento, uso } \\
\text { de digestores anaerópios, melhorar o tempo } \\
\text { e a aplicação do esterco, cobrir o } \\
\text { armazenamento, mudanças nas dietas dos } \\
\text { animais }\end{array}$ \\
\hline Gestão dos fertilizantes & $\begin{array}{l}\text { Aumento na eficiência no uso do nitrogênio } \\
\text { através de melhoramentos genéticos das } \\
\text { espécies que alimentarão os animais, } \\
\text { utilização de fertilizantes orgânicos nas } \\
\text { plantações, realização de testes regulares de } \\
\text { solo, melhorias tecnologias nos fertilizantes, } \\
\text { redução da necessidade de fertilizantes com } \\
\text { o plantio de leguminosas junto às pastagens }\end{array}$ \\
\hline Manejo dos animais & $\begin{array}{l}\text { Combinações genéticas de certas espécies, } \\
\text { melhorias e promoção da saúde do animal, } \\
\text { aumento da eficiência reprodutiva, redução } \\
\text { do rebanho improdutivo, reduções nas taxas } \\
\text { de mortalidade }\end{array}$ \\
\hline Manejo das pastagens & $\begin{array}{l}\text { Adoção de técnicas pastoreio mais } \\
\text { eficientes, seleção de espécies adequadas } \\
\text { para alimentar os animais, plantio de } \\
\text { leguminosas para aumentar estoques de } \\
\text { carbono }\end{array}$ \\
\hline Intensificação sustentável & $\begin{array}{l}\text { Ações que aumentem eficiência da produção } \\
\text { minimizando a necessidade de terras }\end{array}$ \\
\hline
\end{tabular}

Fonte: Adaptado de Herrero et al., 2015; Rojas-Downing et al., 2017. 
Entretanto, a maior parte das propostas e da produção científica existentes atualmente não foca no polo do consumo, mas em como a produção pecuária pode ser mais sustentável ${ }^{207}$. Tendo em vista reduzir não só as emissões de GEE, mas outros impactos ambientais associados, existem diversas ações enunciadas como soluções. O Quadro 5 resume algumas das principais opções de mitigação ligadas à indústria animal.

$\mathrm{O}$ manejo dos dejetos dos animais também pode reduzir as emissões de $\mathrm{CH}_{4}$ e, especialmente, de $\mathrm{N}_{2} \mathrm{O}$. Existem situações onde se pode realizar o armazenamento do esterco, o que já pode minimizar perdas por lixiviação e volatilização (SMITH et al., 2008); nestes casos pode-se aplicar técnicas simples, como a compactação ou cobertura do esterco (CHADWICK et al., 2011), ou abordagens mais complexas envolvendo a digestão anaeróbia (CLEMENS et al., 2006). Os problemas de tais técnicas é que costumam ser viáveis apenas em sistemas intensivos, onde os animais estão confinados e o esterco é coletado com mais facilidade. Na maior parte do planeta, e especialmente no Brasil, o esterco é depositado no campo. A melhoria nos métodos de aplicação dos dejetos, como forma de adubar plantações de grãos e de forragem, também pode reduzir substancialmente a volatilização nesse sentido (HERRERO et al., 2015).

Existe uma grande variedade de aditivos e melhorias alimentares que podem ser feitas na alimentação dos ruminantes que reduzem substancialmente as emissões de $\mathrm{CH}_{4}$, os quais podem incluir aceptores de elétrons alternativos, antibióticos, enzimas, culturas probióticas dentre outros (GERBER et al., 2013). Aumentar a qualidade e a digestibilidade da forragem e da ração oferecida aos animais também contribui para mitigações. Há de se considerar, entretanto, que com tais mudanças também pode ocorrer o aumento na produtividade animal, o que, apesar de reduzir a intensidade das emissões, pode trazer um aumento líquido das emissões, pois pode acabar por incentivar os produtores a aumentar o tamanho dos rebanhos (THORNTON; HERRERO, 2010).

O manejo dos animais também traz opções para a mitigação. Melhorias na saúde dos animais, combinações genéticas, elevação da eficiência reprodutiva estão entre os fatores que podem reduzir a carga de animais improdutivos e, portanto, reduzir emissões de GEE. Similarmente às melhorias na alimentação, o aumento na produtividade decorrente de tais ações também pode, em cenários rentavelmente favoráveis, incentivar o aumento do número

\footnotetext{
${ }^{207}$ É preciso ressaltar que a maior parte das pesquisas existentes se concentram em reduzir GEE de emissões de ruminantes, dada a sua participação dominante nas emissões totais da produção animal (HERRERO et al., 2015).
} 
de animais em uma propriedade, o que reduziria a eficácia das medidas como forma de mitigação (GERBER et al., 2013; HERRERO et al., 2015).

No Brasil, entretanto, tendo em vista que a maior parte das emissões da pecuária estão associadas às mudanças no uso da terra, mais especificamente à conversão de florestas em pastos (BARRETO, 2015), as soluções que focam esse aspecto possuem uma grande relevância. As próprias pastagens, se manejadas corretamente, podem estocar consideráveis quantidades de carbono e otimizar a produção de forragem (BARRETO, 2015; HENDERSON et al., 2015), o que pode ser economicamente atraente em diversas situações (SMITH et al., 2008).

A intensificação sustentável, a recuperação de pastagens degradadas e a integração da pecuária com a lavoura pode reduzir as áreas necessárias para a produção agropecuária futura. De acordo com Amaral et al. (2012), o processo de intensificação já estaria ocorrendo no Brasil, ainda que de maneira mais lenta, uma vez que a quantidade de bovinos cresceu $12 \%$ entre 1995 e 2006, e a área de pastagem diminuiu 3\% no período. Atualmente, cerca de 95\% da produção bovina nacional é criada em sistemas de pastagem (EMPRESA BRASILEIRA DE PESQUISA AGROPECUÁRIA, 2018b).

Em suma, o panorama futuro da pecuária sustentável no Brasil se estrutura, sobretudo, na intensificação e no aumento da produtividade, mas também agrega outras soluções (AMARAL et al., 2012). Está sendo construído um consenso sobre a ideia de que a intensificação pode ser a solução para frear o desmatamento no país (RETTMANN, 2013; VALE; ANDRADE, 2012). Entretanto, limitações e críticas também são levantadas quando analisamos a viabilidade de tais mudanças.

A intensificação baseada na alimentação com ração ${ }^{208}$, frequentemente, acaba transferindo os impactos da pecuária para a agricultura, uma vez que grandes áreas de cultivo acabam sendo necessárias para alimentar os animais. É preciso levar em conta ainda que a intensificação, no contexto brasileiro, pode implicar custos mais elevados, tendo em vista as tecnologias e infraestrutura necessárias. Não há dúvida de que é possível reduzir substancialmente as emissões da produção animal no Brasil (SILVA; RUVIARO; FERREIRA-FILHO, 2017) e no mundo (HERRERO et al., 2015), mas a viabilidade

\footnotetext{
${ }^{208}$ Especialmente os modelos conhecidos como "factory farming", onde o animal costuma passar todo o seu desenvolvimento confinado, que é o que ocorre com maior parte da produção de aves e de suínos no Brasil. Nesse ponto é necessário ressaltar que a intensificação da pecuária não significa, necessariamente, uma transição para esses sistemas, mas trata-se de uma produção animal em espaços menores, processados mais rapidamente, que envolve menos perdas (HEINRICH BÖLL FOUNDATION, 2015).
} 
econômica de tais mudanças deve ser levada em conta, especialmente tendo em vista uma economia capitalista onde a competição e a minimização de custos são fatores preponderantes para a sobrevivência de uma atividade ${ }^{209}$. Além disso, também é possível apontar problemáticas que costumam se agravar com a intensificação, como a questão do bem-estar animal e os problemas associados ao uso de antibióticos (SCHUCK; RIBEIRO, 2015).

O trabalho de Silva, Ruviaro e Ferreira-Filho (2017) aborda especificamente a intensificação pecuária como uma forma de política climática no Brasil, como forma de aliar o crescimento econômico à mitigação de GEE. De acordo com o estudo, e em consenso com outros trabalhos acadêmicos, os processos de intensificação podem reduzir o desmatamento na conversão de florestas em pastos. No entanto, como política climática de mitigação, o resultado final pode acabar sendo contraproducente, uma vez que as emissões líquidas finais podem acabar sendo maiores com o aumento da produtividade. Além disso, deve-se levar em conta que os sistemas intensivos geralmente agravam os problemas com uso excessivo de antibióticos e, dentro da questão ética, é tida como a forma de produção que envolve mais problemas de sofrimento e maus tratos para com os animais, por conta do confinamento (FOER, 2009).

Existem também sistemas extensivos mais sustentáveis, onde uma série de medidas, tais como técnicas de pastoreio ${ }^{210}$ e sistemas de integração ${ }^{211}$ podem ser adotadas para reduzir o impacto ambiental e emissões de GEE das pastagens. A própria produção de "carne orgânica" costuma seguir tais lógicas. No entanto, a produtividade de tais sistemas é reduzida, em comparação aos sistemas intensivos, o que limita a oferta. Nos países industrializados, por exemplo, apenas $2 \%$ da carne vendida é produzida dentro de padrões que podem ser considerados “orgânicos” (HEINRICH BÖLL FOUNDATION, 2015). Nesse sentido é possível questionar se essa forma de pecuária sustentável daria conta de suprir altas taxas de consumo.

Por fim, suprir a demanda atual através de produção pecuária mais sustentável, com reduzidas taxas de emissão de GEE, é tecnologicamente possível; resta investigar se isso é, de

\footnotetext{
${ }^{209}$ É preciso relembrar que, no Brasil, a opção pela pecuária extensiva, baseada em desmatamento se dá, frequentemente, pelo baixo custo de produção (AMARAL et al., 2012; CARVALHO; ZEN, 2017).

${ }^{210}$ Como o "Pastoreio Racional Voisin", que basicamente diz respeito à rotação racional das pastagens, ou ainda o "Manejo de Pastagem Ecológica", o qual também inclui diversificação das espécies forrageiras utilizadas e arborização (MELADO, 2007).

${ }^{211}$ Como, por exemplo, integração lavoura-pecuária, pecuária-floresta ou lavoura-pecuária-floresta (BARRETO, 2015).
} 
fato viável, especialmente se levarmos em conta o aumento esperado da demanda de carne nas próximas décadas, nosso sistema econômico e político, as dinâmicas de uso e ocupação do solo no país, dentre outros fatores. Será que a intensificação e aumento na produtividade, sem a alteração nas tendências de consumo, vai ser capaz de mitigar ou aumentar as emissões totais do setor?

\subsubsection{Consumo de carnes menos impactantes}

Além da intensificação sustentável e da redução do consumo de carne, outras opções também compõem o quadro de soluções com o potencial de reduzir o expressivo impacto que o sistema-carne exerce nas mudanças climáticas.

Como já estabelecido anteriormente, os sistemas de produção com ruminantes representam a maior parte das emissões da pecuária. De modo geral, os bois, representantes quase absolutos desta categoria, emitem muito mais GEE, comparativamente, do que galinhas, porcos e peixes ${ }^{212}$. Logo, a quantidade e velocidade não são os únicos fatores relevantes, mas os tipos de carne consumidos. Ou seja, a escolha das espécies que irão compor nosso cardápio também vai influenciar na forma com que o consumo de animais impacta o aquecimento global ${ }^{213}$ (HERRERO et al., 2015; ROJAS-DOWNING et al., 2017; TILMAN; CLARK, 2014).

Na graduação de emissões de GEE das carnes, os ruminantes representam o polo mais extremo, principalmente no Brasil (OBSERVATÓRIO DO CLIMA, 2017). Esta dinâmica se deve, especialmente, por conta do metano entérico (FOOD AND AGRICULTURE ORGANIZATION OF THE UNITED NATIONS, 2013a). Porém, outros fatores, tais como a menor eficiência energética e de recursos na criação de bois em comparação com outros animais, estão envolvidos nessa disparidade (ROJAS-DOWNING et al., 2017).

De acordo com o relatório do "Environmental Working Group" (HAMERSCHLAG, 2011), o ranking dos piores produtos alimentícios de origem animal, em termos de emissões de GEE, são respectivamente: a carne de cordeiro, carne bovina, queijos, porco, salmão de viveiro, peru, galinha, atum enlatado e ovos. Dentro da opção por tipos de carne menos

\footnotetext{
${ }^{212}$ É possível constatar isso observando a figura 8.

${ }^{213}$ O que se aproxima mais da ideia de "buycott", neologismo utilizado para exprimir opção de compra de serviços e produtos percebidos como ambientalmente e socialmente responsáveis (PORTILHO; CASTAÑEDA, 2009).
} 
impactantes, a forma de produção também pode ser levada em conta. Frutos do mar oriundos da pesca de arrasto jogadas no leito oceânico, possuem emissões de GEE três vezes maiores ${ }^{214}$ que as alternativas que não utilizam redes de arrasto (TILMAN; CLARK, 2014). Logo, também é necessário atentar ao fato de que as mudanças nos processos produtivos podem elevar as taxas médias de emissões destas carnes, tidas como "menos impactantes".

É preciso ressaltar que, apesar da substituição do consumo de carne bovina pela de porcos, frangos e peixes reduzir as emissões em muitos casos, ainda assim, a carga de GEE emitidos na produção de calorias, porções ou proteínas equivalentes de origem vegetal é consideravelmente menor (TILMAN; CLARK, 2014). A produção de carne de galinha e de porco, por exemplo, correspondem a um volume de emissões de GEE 20 a 25 vezes maior em comparação à produção de soja (BAILEY; FROGGATT; WELLESLEY, 2014; SCHUCK; RIBEIRO, 2015), o que se deve a uma alta necessidade de insumos agrícolas e a grandes quantidades de GEE liberados nos processos pós-fazenda (TOORN; BROEK; WORRELL, 2017).

A alternativa das "carnes menos poluentes" representa, por um lado, uma facilidade para aqueles que querem reduzir as emissões da dieta sem largar totalmente o consumo de alimentos de origem animal, mas, por outro lado, pode apresentar um desafio. De acordo com Sordi (2013), dentro de um provável espectro de "carnicidade", a carne bovina, seguramente, estaria situada no extremo superior, ou seja, figuraria como "a carne mais carne dentre as carnes”. Após, seguiriam outras carnes vermelhas, de mamíferos e, logo após, de aves. Os peixes estariam no ponto mais baixo, situados no limite entre carne e "não-carne". Seguindo essa constatação e outras descrições sobre a importância central que é dada à carne bovina dentro da categoria de alimentos de origem animal, principalmente no Brasil (SORDI, 2013), é considerável imaginar que a substituição justamente desta "carne das carnes" possa ser a mais difícil.

Por outro lado, tal substituição pode se alinhar mais facilmente a movimentos, tais como o "slow food" e o "locavorismo", que já comportam outras formas de "carnivorismos alternativos", não apenas no que diz respeito à quantidade e frequência de consumo reduzidas, mas com relação ao tipo de carne que é colocada na dieta, levando em conta o cuidado ético e artesanal nas cadeias produtivas, além da fatores socioambientais (AZEVEDO, 2015; SORDI, 2013; WEISS, 2012).

\footnotetext{
${ }^{214}$ A comparação é feita por emissões de $\mathrm{CO}_{2}$ eq por grama de proteína.
} 


\subsubsection{Outras alternativas e potenciais soluções}

Os alimentos de origem animal, sobretudo a carne, não podem ser resumidos a simples proteínas ou nutrientes, uma vez que estão ligados à diversos rituais, modos de vida e aspectos culturais e sociais, especialmente no Brasil. É preciso ressaltar a existência de certas alternativas que não consistem em substitutos de origem vegetal e nem estão baseadas na produção animal convencional, mas que também possuem um potencial para reduzir as emissões de GEE relacionadas à nossa ingestão de proteínas ${ }^{215}$.

A prática da entomofagia, que consiste no uso de insetos para a alimentação humana, é um costume comum em diversos locais do mundo, sendo um importante componente de diversas culturas alimentares (FOOD AND AGRICULTURE ORGANIZATION OF THE UNITED NATIONS, 2010). A produção de proteínas para a dieta humana através de insetos possui uma eficiência energética muito maior que a realizada convencionalmente pela pecuária industrial. Além disso, alguns insetos possuem uma alta eficiência alimentar, tendo em vista que um grande percentual de sua composição biológica é comestível, como demonstrado pelo caso do grilo na Figura 9. Por conta disso, de modo geral, a utilização de recursos naturais e as emissões de GEE podem ser substancialmente reduzidas através da inclusão de insetos comestíveis na alimentação (FOOD AND AGRICULTURE ORGANIZATION OF THE UNITED NATIONS, 2013b; PREMALATHA et al., 2011).

\footnotetext{
${ }^{215}$ Tomar a substituição do consumo de carne como uma simples questão de substituição de proteínas, apesar de ser uma abordagem relativamente reducionista, pode ser interessante, tendo em vista a percepção que os consumidores e pesquisadores possuem da carne como uma "fonte de proteína" (KIRINUS et al., 2013) e a existência do conceito de "proteínas sustentáveis" abordado por diversos estudos (HARTMANN; SIEGRIST, 2017).
} 
Figura 9 - Percentual comestível de alguns animais

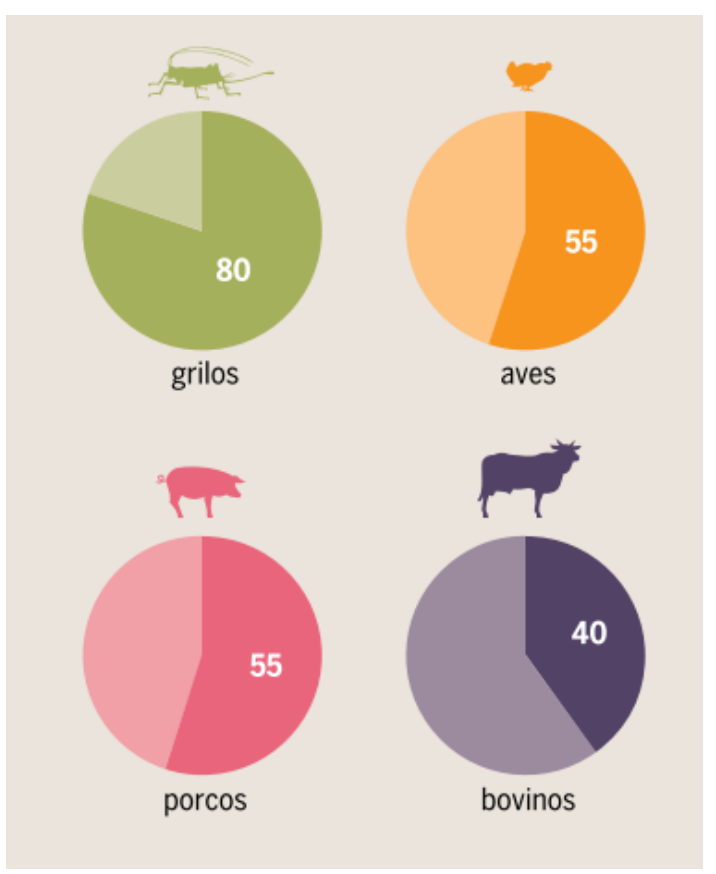

Fonte: Heinrich Böll Foundation, 2015.

Certas espécies já são consumidas tradicionalmente no Brasil, tais como a tanajura (fêmea formigas das saúvas, do gênero Atta), os bichos-das-palmeiras (larvas de besouros Rhynchophorus palmarum e Rhina barbirostris) dentre outros (SANTOS; FLORÊNCIO, 2013). Já é possível comprar pela internet barras protéicas e farinhas fabricadas a partir de insetos, através de empresas nacionais, como a Hakkuna (HAKKUNA, 2018), e até mesmo hambúrgueres feitos com larvas de bicho-da-farinha (Tenebrio molitor), vide Figura 10 (CAPARROS MEGIDO et al., 2016). 
Figura 10 - Hambúrguer feito de larvas bicho-da-farinha (Tenebrio molitor)

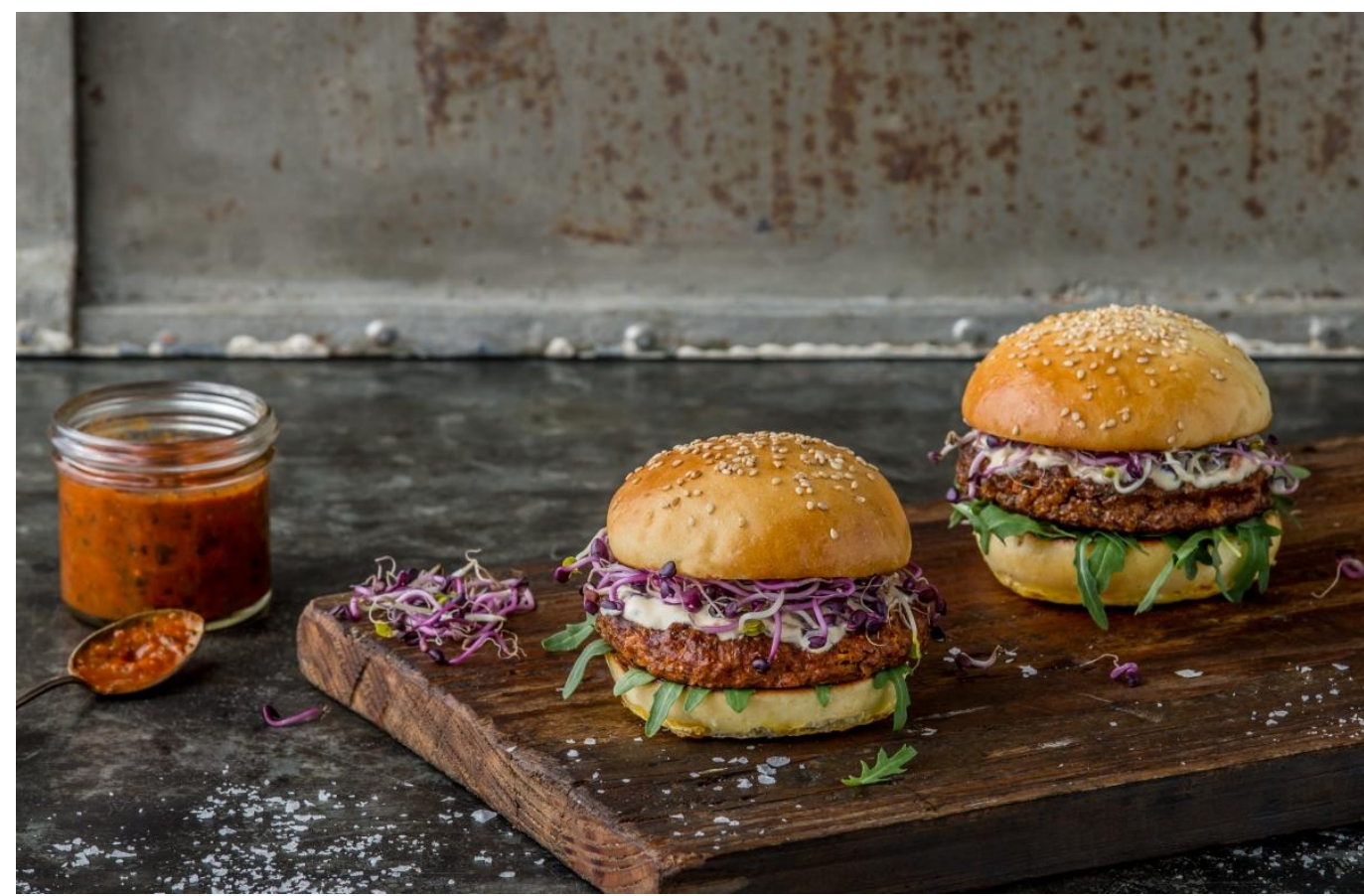

Fonte: Wikimedia Commons (https://goo.gl/iyBzFY).

A aceitação da entomofagia pelos consumidores, no entanto, pode ser controversa, uma vez que alimentos baseados em insetos ainda podem estar associados a sentimentos de medo, insegurança e nojo para algumas pessoas (CAPARROS MEGIDO et al., 2014, 2016). São necessários mais estudos que abordem a aceitação e viabilidade dos insetos como uma alternativa de proteína sustentável para o consumidor brasileiro.

Existe a chamada "carne artificial" ${ }^{216}$, que consiste em cultura de células animais produzidas artificialmente em laboratório. Em 2013, o primeiro hambúrguer produzido dessa forma foi colocado publicamente à prova. Segundo os produtores do experimento, que custou cerca de 250 mil dólares, a carne de laboratório, mostrada na Figura 11, possuía cor, textura e sabor idêntica à convencional (HEINRICH BÖLL FOUNDATION, 2015). Desde então, a carne artificial tem atraído muita atenção e diversos investimentos de iniciativas privadas (MORGAN, 2018), incluindo grandes empresas produtoras de carne (SORVINO, 2018).

\footnotetext{
${ }^{216}$ Também conhecidas como "carne de laboratório", "carne in vitro" ou "carne de cultura".
} 
Figura 11 - Primeiro hambúrguer produzido em laboratório

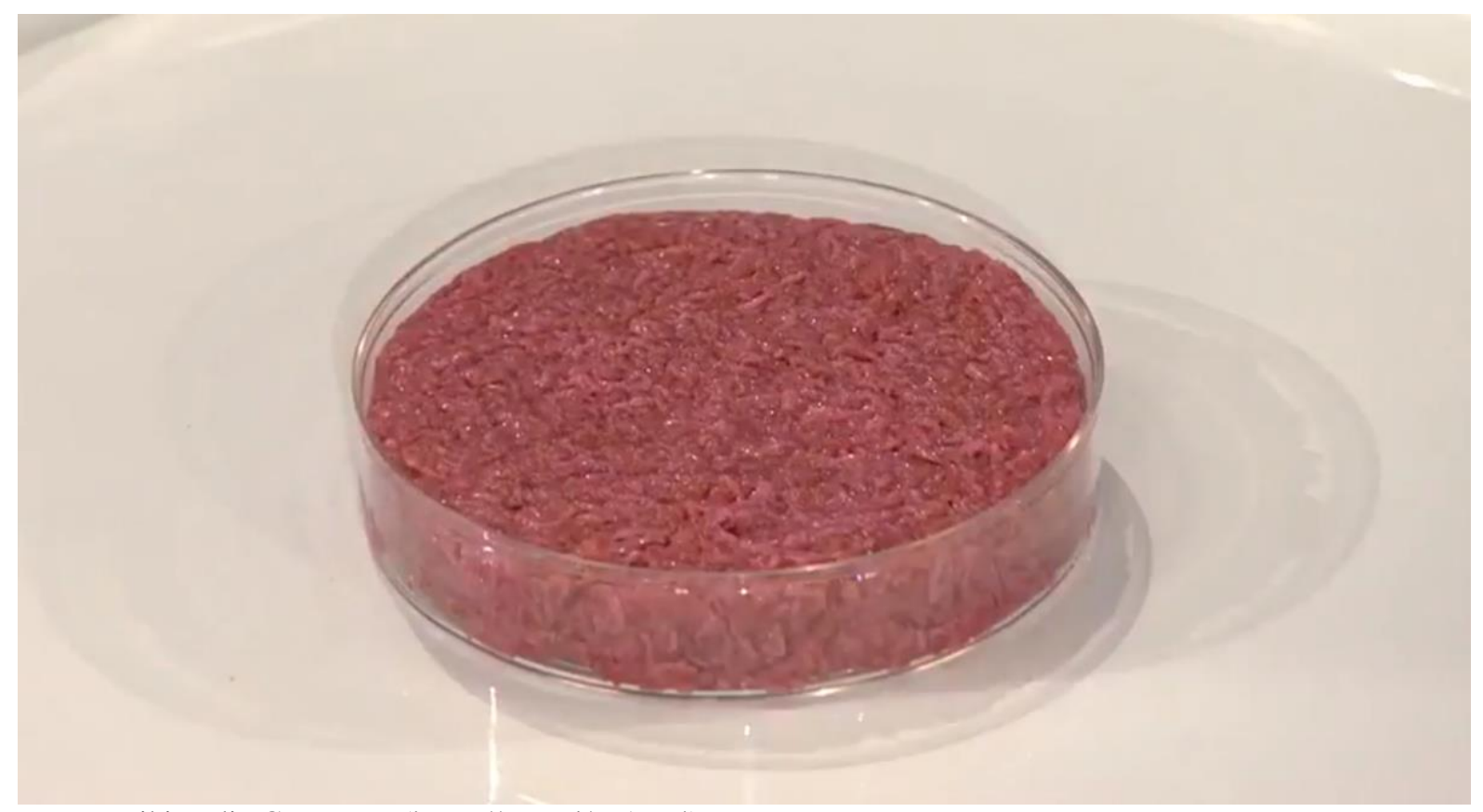

Fonte: Wikimedia Commons (https://goo.gl/ga1Xs4)

De acordo com Tuomisto e Teixeira de Mattos (2011), a produção de carne em laboratório, em comparação com a produção de carne convencional da Europa, envolve uma redução de: 7 a 45\% no uso energia, 78 a 95\% nas emissões de GEE, 82 a $89 \%$ do uso de água e $99 \%$ na necessidade de terras. Entretanto, essa produção também pode enfrentar obstáculos $^{217}$. Temos a questão da aceitação pelos consumidores (VERBEKE; SANS; VAN LOO, 2015) e, além disso, o custo de produção da carne artificial ainda é muito elevado, o que, no momento, a torna inviável economicamente, de acordo com diversos autores (HOCQUETTE, 2016). Entretanto, o avanço da tecnologia e redução nos custos da produção podem acabar fazendo dessa uma das soluções para os problemas ambientais da carne no futuro.

É possível citar até mesmo a produção de proteína microbiana, que também está associada a custos ambientais reduzidos. De acordo com Matassa, Boon e Pikaar (2016), é possível produzir proteínas através de algas, leveduras, fungos e biomassa celular bacteriana, com uma pegada ecológica reduzida, inclusive, no que diz respeito às emissões de GEE. Entretanto, a forma com que tais proteínas podem integrar a alimentação pode ser

${ }^{217}$ Há ainda a crítica de que a "carne artificial" pode ser um fator que vai agravar o distanciamento entre as pessoas e suas fontes de alimento (HEINRICH BÖLL FOUNDATION, 2015), além do questionamento se o seu consumo seria eticamente adequado para vegetarianos, uma vez que seu o processo produtivo não envolve diretamente a exploração de animais, mas envolve ainda tratam-se de células animais. 
problemática, e há o risco de agravar o processo de "medicalização da dieta", como descrito por Proença (2010). A comida não pode ser substituída por suplementação e uma alimentação digna e equilibrada não se trata somente de uma questão de ingestão de nutrientes, mas envolve diversos outros fatores que são essenciais para a vida humana.

\subsection{Síntese das controvérsias}

Uma controvérsia é, resumidamente, uma situação onde diferentes atores discordam em relação a algo. De maneira geral, elas se iniciam no momento que os atores discordam e não podem mais se ignorar e, por sua vez, terminam quando os atores alcançam algum compromisso de consenso sólido. No âmbito de seu estudo no meio científico, estas dizem respeito à parte da ciência que ainda não está estabilizada e não é tida como consenso na academia e, além de tudo, na qual existe certo grau de incerteza compartilhada e disputas envolvidas (LATOUR, 2005; VENTURINI, 2010a, 2010b).

No estudo das controvérsias, apesar das mesmas se apresentarem complexas e, geralmente, cercadas de conflitos, são ótimas ocasiões para observar a construção de novas ideias e a solidificação de conhecimentos, lembrando ainda que aquelas que envolvam conhecimento científico e técnico são especialmente importantes para a sociedade (ABRAMOVAY, 2007; CALLON, 2006; COLLINS; PINCH, 1998; LATOUR, 2005).

Tais controvérsias, que enrolam e confundem em uma mesma trama, questões não apenas sociais, mas também técnicas, podendo assim ser definidas como sociotécnicas, não existem apenas no âmbito acadêmico, mas, apesar de girarem em torno de questões científicas, envolvem cultura, política, tecnologia, moral, etc (LATOUR, 2005). No caso estudado, que compreende o vegetarianismo como uma alternativa para a redução de emissões de gases de efeito estufa, também é possível identificar esta trama de fatores que compõe o tema.

Além disso, apesar de suas particularidades, todas as controvérsias partilham algumas características intrínsecas, observadas por diversos autores, especialmente Latour (2005), e reunidas pelo trabalho de Venturini (2010a). É possível identificar também tais atributos ao longo da descrição e do desdobramento desta pesquisa, o que endossa a natureza controversa do tema: 
- Diversidade de atores (LATOUR, 2005; LAW, 1987): A discussão do vegetarianismo ambiental, especificamente com o foco que é dado, envolve atores humanos e não humanos, tais como os consumidores e os próprios animais; elementos naturais e biológicos: como a molécula de metano e a energia transferida entre níveis tróficos; organizações globais, como a FAO e o IPCC; dentre outros. Estes atores agem de formas distintas e participam de relações heterogêneas dentro do assunto em função das relações as quais são submetidos.

- Irredutibilidade (LATOUR, 2005; VENTURINI, 2010a): de modo geral, controvérsias não podem ser simplificadas, ou sequer resumidas em uma só pergunta. Isso se deve ao fato de que, nelas, os atores tendem a discordar inclusive dos preceitos que a configuram. Em suma, os atores não apenas discordam sobre as respostas, mas eles também discordam sobre os pressupostos envolvidos na questão. Nesse sentido, quando questionamos qual o papel da indústria de produção animal na segurança alimentar, por exemplo, o próprio conceito do que é segurança alimentar se desestabiliza, uma vez que diferentes grupos de atores possuem perspectivas opostas sobre sua definição e o que a mesma envolve ${ }^{218}$.

- Discussão e debate (LATOUR, 2005; VENTURINI, 2010a): geralmente, as controvérsias estão sempre sendo debatidas em diversas esferas, de maneiras distintas e por um número cada vez maior de atores. Nesse sentido, é possível perceber que a discussão do vegetarianismo ambiental, levando em conta as subcontrovérsias e temas que a compõe, não se limita ao âmbito acadêmico, mas está, até certo ponto ${ }^{219}$, presente na mídia (por exemplo, na internet) de maneiras diversas (CAPUTO et al., 2012).

- Conflitos (LATOUR, 2005; VENTURINI, 2010a): apesar de algumas controvérsias não se tornarem lutas propriamente ditas ${ }^{220}$, a maioria vem acompanhada de conflitos. Por mais que diversos assuntos que envolvam as mesmas sejam triviais, os atores tendem a levar muitas discussões à sério, pois, o que pode estar em jogo em muitos debates envolve diversos interesses, valores pessoais, dentre outros fatores. $\mathrm{O}$

\footnotetext{
${ }^{218}$ Vide as perespectivas opostas sobre a relação entre a indústria de produção animal e a segurança alimentar no item 3.1.1.

${ }^{219}$ Tendo em vista, como já mencionado, certo grau de desconhecimento e a supressão de toda a questão na mídia.

${ }^{220}$ Como é o caso da controvérsia estudada nesta pesquisa.
} 
vegetarianismo, especialmente o seu aspecto mais político e ativista, acaba envolvendo conflitos diversos, como mostrado pelo trabalho de Abonizio (2016) e Sordi (2013).

- Associações nas formas mais dinâmicas (CALLON, 1987; LATOUR, 2005; VENTURINI, 2010a): por exemplo, a controvérsia em questão alia, em uma mesma frente, ambientalistas, vegetarianos, animais, cientistas, dentre outros atores.

A Figura 12, apresenta as principais controvérsias encontradas nesta pesquisa ${ }^{221}$, além da sua respetiva escala ${ }^{222}$.

Figura 12 - Controvérsias identificadas e suas escalas

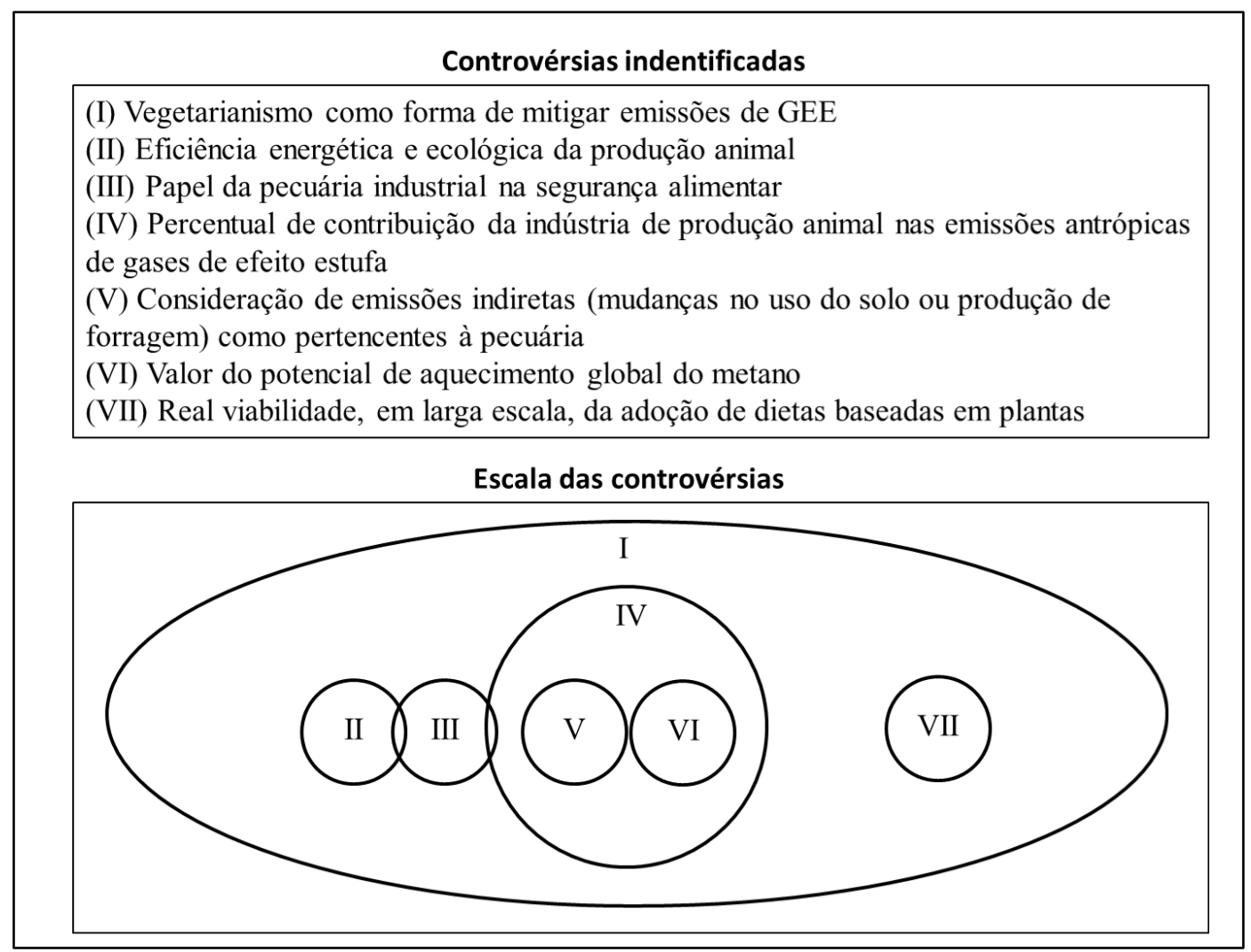

Fonte: Elaborado pelo autor.

O ponto principal do trabalho foi investigar o vegetarianismo como uma forma de reduzir as emissões de GEE da nossa alimentação. Nesse sentido, o potencial hipotético de

\footnotetext{
${ }^{221}$ Há algumas controvérsias citadas ao longo desta dissertação que não constam na Figura 12, pois não se relacionam de forma tão direta com foco central desta pesquisa.

222 Escala das controvérsias, como descrito por Venturini (2010b), é um elemento utilizado para representar controvérsias sociotécnicas e as subcontrovérsias que as compõem.
} 
minimizar emissões através de DBP não apresentou grandes discordâncias na literatura científica que aborda o tema ${ }^{223}$, tal qual já foi apresentado anteriormente.

Entretanto, se desdobramos o assunto, outras subcontrovérsias, que desestabilizam a suposta contribuição das DBPs para reduzir emissões, acabam por trazer complexidade ao tema e lhe conferir um caráter mais controverso ${ }^{224}$.

A questão da eficiência energética e ecológica da pecuária, em comparação com a agricultura, apresenta uma divergência. Por um lado, genericamente, a disparidade energética e ecológica entre as duas formas de produção de alimento explica os altos impactos da produção animal em larga escala. No entanto, a perspectiva que enfatiza a alta densidade nutricional e energética da carne (MEDEIROS, 2008), além de exemplos em que a produção animal utiliza recursos que não teriam como ser aproveitados pelo ser humano ou terras em que não é possível desenvolver agricultura (HERRERO et al., 2011) contrapõem esse ponto de vista inicial.

Essa segunda perspectiva, da carne energética e ecologicamente eficiente, faz com que a controvérsia II esteja circunscrita dentro da I na Figura 12, pois, tal argumento pode ser utilizado como forma de estabelecer a indústria de produção animal como uma forma importante, eficiente e, até mesmo, essencial de se produzir alimentos. O mesmo ocorre com o ponto de vista da pecuária industrial como sendo um fator que garante a segurança alimentar, referente à controvérsia III.

Ambas as controvérsias (II e III) se relacionam: a forma com que a indústria de produção animal é encarada, no que diz respeito à segurança alimentar, pode envolver a suposta eficiência ou ineficiência energética e ecológica da mesma; além disso, também pode ser influenciada pelo quão impactante ela é considerada no que diz respeito às emissões de GEE (controvérsia IV).

Estabelecer se o vegetarianismo, que envolve a retirada de certos produtos de origem animal na dieta, pode reduzir emissões de GEE da alimentação também pode depender do quão impactante a pecuária é considerada nesse sentido. A controvérsia IV, explorada nos itens 2.2.1 e 2.2.2, mostra um elevado grau de variação no percentual de emissões antrópicas de GEE atribuídos à indústria de produção animal. Tal variação se dá por questões

\footnotetext{
${ }^{223}$ Ainda que levemos em conta alguns casos pontuais que fogem à regra, em que a produção de certos alimentos de origem vegetal emitem mais GEE do que alguns de origem animal.

${ }^{224}$ Assim, o vegetarianismo como forma de reduzir emissões de GEE torna-se uma controvérsia, de fato.
} 
metodológicas que influenciam estudos que visam mensurar tais valores (subcontrovérsias $\mathrm{V}$ e VI).

Além disso, os percentuais de emissões da pecuária podem variar significativamente em função dos GWPs utilizados para o metano. Tanto a opção entre o GWP de 20 ou de 100 anos, como o próprio valor do GWP, que vem sofrendo constante revisão, configuram a subcontrovérsia VI.

A própria viabilidade e eficácia de mudanças para DBP em larga escala também é questionada (subcontrovérsia VII), especialmente no que diz respeito ao vegetarianismo, que, por se relacionar a abstenção, e não apenas a moderação do consumo de carne, envolve muitas limitações e resistências, como já mencionado. Diversos estudos apresentam significativos benefícios hipotéticos de DBP para reduzir emissões de GEE da nossa alimentação, declarando que mudanças nesse sentido não são apenas opções de mitigação ${ }^{225}$, mas medidas necessárias ${ }^{226}$. Outros estudos, porém, questionam se uma redução no consumo de alimentos de origem animal é mesmo realista (DAGEVOS; VOORDOUW, 2013), especialmente levando em conta as preferências dos consumidores, que costumam ser conservadoras (HERRERO et al., 2015), além de todo um emaranhado de questões culturais, sociais, econômicas e políticas abordadas nos itens 4.1.1 e 4.1.2.

\footnotetext{
${ }^{225}$ Como as recomendações da FAO e do IPCC.

${ }^{226}$ Ponto de vista defendido, por exemplo, por Springmann et al. (2018) e Searchinger et al. (2018), o qual também coloca a necessidade de redução do desperdício de alimentos e certas melhorias tecnológicas na produção de modo paralelo. Evidentemente, tal perspectiva também representa boa parte da visão vegetariana de que é necessário reduzir o consumo global de carne.
} 


\section{CONCLUSÕES}

O aumento no número de adeptos do vegetarianismo nos últimos anos, as crescentes controvérsias sobre o assunto, a multiplicidade de tópicos entrelaçados, bem como o desabrochar de um promissor campo de pesquisa, fazem deste sistema alimentar um interessante e complexo tema a ser estudado.

Apesar da definição do vegetarianismo, enquanto uma dieta, ser relativamente precisa, motivações, debates e assuntos que cercam o tema são variados. Além disso, seja como uma espécie de ativismo alimentar, consumo político, boicote ou como uma simples mudança no cardápio, sem grandes pretensões de mudar o mundo, as práticas vegetarianas, de modo geral, dizem respeito, necessariamente, ao não-consumo de carne ${ }^{227}$, podendo, ou não, incluir outros alimentos de origem animal. Ou seja, trata-se, por definição, de uma dieta, mas pode ir, e geralmente vai, muito além, assumindo contornos distintos e se relacionando com outros movimentos alternativos à nossa alimentação convencional.

Ainda que as principais justificativas para a adoção de dietas vegetarianas não apareçam de modo purificado e, pelo contrário, se misturem, é possível constatar que, apesar da crescente importância, questões ambientais costumam assumir uma posição secundária ou terciária para a adoção do vegetarianismo, sendo que critérios ligados à saúde, nutrição ou questões de natureza ética ligada aos direitos dos animais, costumam figurar em primeiro plano.

No entanto, a junção do vegetarianismo ao ambiental aponta para uma concepção do saudável que extrapola o aspecto individual e antrópico do conceito, sugerindo que é necessário levar em conta fatores e relações que vão além da nutrição do corpo humano e envolvem questões ambientais em nossas dietas e escolhas alimentares, seja lá qual for o grau de poder que realmente possuímos para realizar tais "escolhas".

Devido aos diversos problemas ambientais diretamente associados à indústria de produção animal, a relação entre vegetarianismo e meio ambiente tem ganhado importância e sido cada vez mais debatida em diferentes esferas. Diversos estudos acadêmicos, relatórios de instituições internacionais e trabalhos investigativos corroboram os significativos impactos socioambientais envolvidos na pecuária em escala industrial.

\footnotetext{
${ }^{227}$ É preciso ressaltar que a carne, portanto, possui um lugar central em toda a discussão, não apenas devido à importância do seu não-consumo na definição do vegetarianismo, mas, por conta de ser o elemento principal da criação animal, seja na produção, no rendimento ou no que diz respeito à demanda e consumo.
} 
Tal situação é explicada, sobretudo, pela perda de energia entre os níveis tróficos das pirâmides alimentares. Nesse sentido, em tese, produzir alimentos através da pecuária demanda um fluxo muito maior de matéria e energia quando comparado com a agricultura, exigindo, portanto, maiores quantidades de recursos e gerando um grau mais elevado de externalidades. No caso do Brasil, de modo geral, tal disparidade costuma se verificar tendo em vista critérios como produção de proteínas e calorias e até emissões de GEE. No entanto, existem diversas exceções a essa regra e certas formas de se consumir animais em situções específicas utilizam recursos de forma mais eficiente, seja com áreas em que não seria possível produzir cultivos agrícolas, com pesca de subsistência respeitando taxas em que as populações de peixes conseguem se recuperar ou alimentando os animais com plantas descartadas que seriam impróprias para consumo humano. Além disso, se considerarmos o alimento isoladamente, sob uma ótica mais reducionista, desconsiderando suas trocas energéticas ao longo de sua produção, é possível afirmar que a carne e alimentos de origem animal são energeticamente eficientes, tendo em vista que possuem uma alta densidade calórica. Esse ponto estabelece a primeira subcontrovérsia encontrada sobre o assunto, sendo que a principal divergência entre os pontos de vista está na adoção de uma visão mais sistêmica (carne é ineficiente), considerando relações, ou mais reducionista (carne eficiente), atendo-se ao alimento por si.

Por conta desta disparidade ecológica e suas implicações, que já foram observadas empiricamente e registradas por diversos autores, dietas vegetarianas ou baseadas em plantas são apontadas como sendo mais sustentáveis ou menos impactantes do que aquelas que incluam grandes quantidades de alimentos de origem animal. Entretanto, resumir o assunto a matéria, energia e racionalidades de uso de recursos é uma visão consideravelmente limitada.

A pecuária possui uma notável importância no PIB do país, na manutenção de milhões de empregos, além de ser uma atividade econômica estrutural em diversos municípios. Entretanto, o crescimento da produção pecuária, nas escalas e formas hegemonicamente industriais praticadas atualmente, se faz sobre um elevado custo para o meio ambiente, para os cofres públicos e contribuintes ${ }^{228}$, além de ameaçar os pequenos produtores e apresentar significativos problemas trabalhistas no setor. Em suma, sob certa perspectiva, tal indústria pecuária brasileira possui, até certo ponto, uma grande importância econômica, mas a mesma

${ }^{228}$ Vide os subsídios do BNDES para grandes produtoras de carne nacionais, como citado no item 3.1. 
o faz concentrando renda nas mãos de poucas empresas sobre um custo ambiental e humano consideravelmente alto.

Especialmente no Brasil, a carne está entre os alimentos mais consumidos. Logo, além de sua relevância na nutrição, diversos aspectos da cultura estão centrados no consumo de carne, ou seja, sua importância também transcende o aspecto alimentar e se extende a rituais, modos de vida, dentre outros fatores. Nesse sentido, parece que a aposta do vegetarianismo estaria situada em opções substitutas, sejam elas derivadas de vegetais ou fungos, que não apenas suprissem a função nutricional do alimento, relacionada geralmente com as proteínas, mas que pudessem cumprir os papéis específicos que a carne possui na vida do brasileiro. São necessários também mais estudos que compreendam este aspecto do vegetarianismo.

No que diz respeito à segurança alimentar e nutricional, também foram identificados dois pontos de vista discordantes. Por um lado, a pecuária é considerada essencial, pois supre milhões de pessoas com proteína animal; por outro, ela é considerada uma ameaça, devido aos seus significativos impactos socioambientais. Sem adentrar ainda em outras formas de produção de animais mais sustentáveis e deixando de lado posições binárias que situam a produção animal em uma posição de "inimiga" ou "amiga" da segurança alimentar, é preciso reconhecer que a escala e forma com que a produção animal atual se configura gera e agrava diversos riscos para alimentação e, até mesmo, para a sobrevivência humana neste planeta, sem deixar de compreender inegável dependência alimentar dessa produção na maior parte da sociedade. Levando em conta tal cenário, unido ao grande poder político e econômico que o agronegócio possui no Brasil, há um grande desafio com consideráveis obstáculos, o qual nos leva a questionar se as mudanças necessárias para atenuar essa situação devem estar focadas no polo do consumo, dos processos produtivos ou em ambos. As perspectivas dissonantes sobre a relação entre pecuária e segurança alimentar, no entanto, configuram outra subcontrovérsia identificada no trabalho.

Um fator que agrega ainda mais importância à discussão são as tendências e cenários de mudanças nos padrões de consumo para as próximas décadas. É estimado que a demanda mundial por carne pode dobrar até 2050 , especialmente por conta do aumento do poder aquisitivo das populações urbanas nos BRICS, especialmente na China. Em certos contextos, a carne costuma, inclusive, simbolizar o status social. Apesar disso, as populações que já atingiram taxas máximas de ingestão de carne do planeta estão nos países desenvolvidos, 
onde existem até evidências que apontam para uma lenta, mas progressiva, redução no consumo.

Apesar da antagonia entre o número crescente de pessoas que estão reduzindo ou se abstendo da ingestão de carne e daqueles que aumentam o seu consumo, o número de pessoas pertencentes ao segundo grupo é consideravelmente maior. Logo, tendo em vista os significativos impactos ambientais da produção animal atual, o cenário futuro se torna ainda mais preocupante.

Tratando-se das mudanças climáticas, recorte temático escolhido para abordar a relação entre vegetarianismo e meio ambiente, foi identificada uma significativa subcontrovérsia acerca do percentual de contribuição da indústria de produção animal no aquecimento global antropogênico. Devido a diferenças metodológicas (ACV e inventários de GEE), consideração ou desconsideração de emissões indiretas (produção de ração, mudanças no uso do solo, transporte e refrigeração da carne) e o uso de diferentes GWP atribuídos ao metano ${ }^{229}$, a responsabilidade da pecuária nas emissões antrópicas globais de GEE varia desde $8 \%$ até $51 \%$. Essa significativa variabilidade possui implicações diversas, podendo gerar incertezas e atrapalhar tomadas de decisões sobre o assunto, além de confundir a opinião pública.

No caso do Brasil, onde as estimativas de emissões costumam seguir as recomendações metodológicas para elaboração de inventários de GEE do IPCC, o que mais tem gerado emissões nos últimos anos é o setor denominado "mudanças de uso no solo". No entanto, se deixarmos de lado as categorias estabelecidas pelo IPCC e abordarmos as emissões por atividade econômica, a pecuária passa a ser o fator que mais gera emissões. Devido à marcante dinâmica extensiva da indústria de produção animal nacional, o setor figura como atividade antropogênica que mais desmata e ocupa territórios. Logo, uma grande parcela de emissões que é atribuída as "mudanças de uso do solo" trata-se da conversão de florestas para pastagens. Emissões indiretas, oriundas de cultivos destinados à produção de ração para animais, também podem ser, ou não, atribuídas à produção animal. É possível perceber, portanto, que as emissões relacionadas com a pecuária, neste tipo de metodologia, acabam por se dissolver em outros setores, o que não costuma ocorrer com ACVs. Devido à

\footnotetext{
${ }^{229} \mathrm{O}$ valor de GWP do metano, especialmente significativo para estimativas de emissões do setor pecuário, apresentou-se como uma subcontrovérsia baseada em escolhas metodológicas (escolha entre o uso do GWP de 20 ou de 100 anos). Além disso, há uma constante revisão dos valores por parte de cientistas climáticos, como no caso do trabalho de Etminan et al. (2016).
} 
limitação de tempo e do escopo deste trabalho, tais questões, que demandariam uma considerável atenção, não foram aprofundadas, mas sugerem futuros trabalhos que se dediquem a investigar as controvérsias sobre parcela de contribuição do setor pecuário para o AGA e os critérios utilizados para estabelecer os recortes setoriais nos inventários de emissões de GEE.

É necessário destacar um nítido protagonismo da criação de ruminantes nas emissões da agropecuária nacional, não apenas pela questão do metano, mas pela produção extensiva relacionada em desmatamento. Ou seja, maior parte do problema está centralizado na carne bovina, que costuma ser, neste aspecto, o exemplo extremo de maior impacto dentro da criação de animais para alimentação da nossa sociedade moderna.

Considerando todos os trabalhos revisados, há um certo consenso sobre o potencial que dietas baseadas em plantas possuem para mitigar as mudanças climáticas, com algumas exceções. De modo geral, moderar ou se abster de alimentos de origem animal pode reduzir, de forma significativa, as emissões de GEE relacionadas à nossa alimentação. Isso vai de acordo com recomendações de numerosos estudos científicos e relatórios de instituições diversas, tais como a FAO e o IPCC.

A demanda influencia e sustenta diretamente a produção, logo, o consumidor é um elemento importante em toda a questão, representando um ator ativo e influente nas dinâmicas do sistema-carne, e que possui, de fato, uma grande capacidade para gerar mudanças através de ações de boicote. É preciso, entretanto, destacar que as mudanças nos padrões de consumo de carne possuem significativas críticas e obstáculos. Além de alguns casos específicos, em que os sistemas alimentares e a nutrição podem ser de fato prejudicadas com a retirada da produção animal, a importância e dependência da carne, toda uma conjuntura econômica e política, paradigmas, a supressão dos problemas ambientais da pecuária na mídia, dentre diversos outros fatores representam obstáculos para a adoção de DBP na sociedade moderna.

É preciso destacar que o vegetarianismo é diferente de certas práticas que sugerem a mudança para um consumo moderado de carne. Perspectivas ligadas a uma abstenção total podem ser consideradas mais radicais e, portanto, menos viáveis. No entanto, princípios éticos que partem do pressuposto de uma eliminação total do consumo de certos alimentos de origem animal são o fator chave que torna possível a real mudança na alimentação para muitos, vide o crescimento do veganismo. Levando em conta tudo isso, a ideia de DBP parece ser adequada pois, ao mesmo tempo que sugere claramente uma mudança nos padrões 
alimentares, no sentido de consumir mais plantas e menos animais, abre um espectro mais amplo de opções, que vão desde uma moderação até a total abstenção.

Em outras palavras, essa recomendação pela adoção de DBP considera que as consequências da nossa forma de alimentar extrapolam o espaço individual e geram riscos diversos, mas, ao mesmo tempo que propõe mudar isso, também levam em conta o fato de que alimentação é uma questão muito pessoal e delicada.

Tendo em vista o problema de emissões da pecuária industrial como um todo, soluções relacionadas às mudanças nos processos produtivos, especialmente aquelas que melhorem a eficiência das pastagens, são as que, atualmente, possuem maior visibilidade e aceitação. A intensificação sustentável da produção animal, especialmente no Brasil, também apresenta um significativo potencial para reduzir as emissões do setor através de práticas e técnicas diversas. Entretanto, essa opção também pode enfrentar resistência, por conta de seu elevado custo financeiro e sua necessidade de infraestrutura e tecnologia. Além disso, o aumento na produtividade animal pode acarretar no crescimento dos rebanhos, o que pode resultar em um aumento líquido das emissões diretas de GEE no fim das contas.

A pecuária extensiva sustentável também pode representar uma opção, com técnicas de pastoreio e sistemas de integração que reduzem significativamente os impactos ambientais, estando relacionados à produção de uma carne de maior qualidade e, até mesmo, com o cumprimento dos padrões de produção animal orgânica. No entanto, esta também apresenta limitações por conta de possíveis custos elevados e envolve grandes áreas para produção, o que se torna um problema quando consideramos suprir altas taxas de consumo de carne através destes sistemas.

Outras soluções, como entomofagia e a carne artificial, aparecem como opções para reduzir emissões de GEE e os impactos ambientais da nossa alimentação. No entanto, também envolvem incertezas por conta de obstáculos culturais, tecnológicos e financeiros.

Logo, se considerarmos que "a redução do consumo é uma condição para um mundo efetivamente sustentável” (ZANIRATO; ROTONDARO, 2016. p. 87) e levarmos em conta os impactos ambientais da indústria de produção animal, especialmente no que diz respeito às emissões de GEE da produção agropecuária e das mudanças de uso do solo, a adoção de DBP e a redução no consumo de carne podem ser consideradas mudanças necessárias para uma alimentação sustentável, como afirmam trabalhos acadêmicos recentes e relatórios de instituições internacionais. 
Levando em conta a importância de respeitar decisões alimentares individuais, o fato de que a real viabilidade e aceitação da abstenção do consumo de carne envolve muitas incertezas e limitações e que, além disso, discutir um "vegetarianismo ambiental", em certos $\operatorname{contextos}^{230}$, não faz muito sentido, devemos ressaltar que as dietas vegetarianas não devem ser impostas. Também é preciso ressaltar que nem sempre há uma "escolha" alimentar de fato, uma vez que muitas pessoas possuem uma forte dependência para com a carne, em diversos aspectos. Entretanto, tendo em vista questões socioambientais, especialmente no que diz respeito à mitigação das mudanças climáticas, as DBP são muito bem vindas e desejáveis de modo geral e, portanto, podem ser estimuladas, desde que haja cuidado e respeito a questões de transição e adaptação nutricional e às especificidades alimentares locais, levando em conta, também, as limitações intrínsecas ao próprio vegetarianismo e perspectivas de abstenção.

O vegetarianismo, como forma de mitigação de emissões de GEE, divide opiniões dentro de uma complexidade de tópicos e subcontrovérsias, ainda que haja certo consenso sobre seus benefícios hipotéticos nesse sentido. É necessário levar em conta as visões dissonantes dos atores que compõe esse debate para evitar incorrer em soluções simplistas e que não se sustentem por ignorar aspectos sociais ou técnicos. Contudo, é preciso considerar, de forma sistêmica, toda a ampla gama de soluções para os impactos ambientais da agropecuária, bem como suas respectivas limitações e potencialidades, estejam elas focadas em mudanças nos padrões de consumo, regulações no mercado ou melhorias nos processos produtivos da indústria animal. Estudos que se dediquem a investigar a complexidade destas múltiplas abordagens na mitigação das emissões de GEE relacionadas à alimentação são importantes para auxiliar o debate público e as tomadas de decisões técnico-científicas e políticas. Sobretudo destaca-se a necessidade de trabalhos interdisciplinares, que não excluam nem fatores sociais nem questões técnicas, que considerem incertezas e controvérsias e que, por sua vez, apresentem prioridades realistas entre as estratégias e ações possíveis para promover uma alimentação mais sustentável, particularmente levando em conta a complexidade do contexto brasileiro atual.

\footnotetext{
${ }^{230}$ Situações em que a produção animal não apresenta grandes impactos e os animais são consumidos localmente em taxas muito baixas, como, por exemplo certas formas de pecuária de subsistência citadas no item 4.1.1.
} 


\section{REFERÊNCIAS ${ }^{231}$}

ABDON, M. DE M. et al. Análise do desmatamento no bioma Pantanal até o ano 2002. Anais $1^{\circ}$ Simpósio de Geotecnologias no Pantanal. Anais...Campo Grande: Embrapa Informática Agropecuária/INPE, 2006. Disponível em:

<https://www.alice.cnptia.embrapa.br/alice/bitstream/doc/9406/1/APAnaliseAbdonetalGeopa ntanal2006.pdf>. Acesso em: 12 nov. 2018

ABONIZIO, J. Consumo alimentar e anticonsumismo: veganos e freeganos. Ciências Sociais Unisinos, v. 49, n. 2, p. 191-196, 2013.

ABONIZIO, J. Conflitos à mesa: vegetarianos, consumo e identidade. Revista Brasileira de Ciências Sociais, v. 31, n. 90, p. 115-137, 2016.

ABRAMOVAY, R. O combate à fome no limiar do século XXI. 2000. Disponível em: $<$ http://ricardoabramovay.com/o-combate-a-fome-no-limiar-do-seculo-xxi/>. Acesso em: 23 nov. 2018.

ABRAMOVAY, R. Bem vindo ao mundo da controvérsia. In: VEIGA, J. E. DA (Ed.). . Transgênicos: Sementes da Discórdia. São Paulo: SENAC. p. 129-168. 2007.

ADAMS, C. J. The sexual politics of meat: a feminist-vegetarian critical theory. Londres: Continuum, 2015.

AGÊNCIA BRASILEIRA DE DESENVOLVIMENTO INDUSTRIAL. Relatório de acompanhamento setorial indústria de couro. Brasília: Agência Brasileira de Desenvolvimento Industrial - ABDI Qualquer, 2011.

ALEXANDRATOS, N.; BRUINSMA, J. World agriculture towards 2030/2050: the 2012 revision. Roma: Food and Agriculture Organization of the United Nations, 2012.

ALISSON, E. Contribuição humana para as mudanças climáticas é inegável, avaliam cientistas. Disponível em: <http://agencia.fapesp.br/contribuicao-humana-para-as-mudancasclimaticas-e-inegavel-avaliam-cientistas/27777/>. Acesso em: 2 dez. 2018.

ALLIEVI, F.; VINNARI, M.; LUUKKANEN, J. Meat consumption and production Analysis of efficiency, sufficiency and consistency of global trends. Journal of Cleaner Production, v. 92, p. 142-151, 2015.

ALTOÉ, I. M. Acionando memórias afetivas: a releitura de pratos-totem na culinária vegana. Trabalho de Conclusão de Curso (Bacharel em Jornalismo) - Departamento de Comunicação Social, Centro de Artes, Universidade Federal do Espírito Santo, Vitória, 2017.

AMARAL, G. et al. Panorama da pecuária sustentável. Agroindústria - BNDES Setorial, v. 36, p. 249-288, 2012.

${ }^{231}$ De acordo com a Associação Brasileira de Normas Técnicas (ABNT NBR 6023, 2002). 
ARGUMENTOS VEGANOS. Vegetarianismo não faz sentido, 2017. Disponível em: $<$ https://www.youtube.com/watch?v=h48StYpirT8>. Acesso em: 15 nov. 2018.

ASSOCIAÇÃO BRASILEIRA DAS INDÚSTRIAS EXPORTADORAS DE CARNES. Perfil da pecuária no Brasil: relatório anual. São Paulo: Associação Brasileira das Indústrias Exportadoras de Carne - ABIEC, 2018.

ASSOCIAÇÃO BRASILEIRA DE NORMAS TÉCNICAS. NBR 6023: informação e documentação: referências: elaboração. Rio de Janeiro, 2002. 24 p.

ASSOCIAÇÃO BRASILEIRA DE NORMAS TÉCNICAS. NBR ISO 26000 - Diretrizes sobre responsabilidade social. Rio de Janeiro, 2010. 110 p.

ASSOCIAÇÃO BRASILEIRA DE PROTEÍNA ANIMAL. Nota à imprensa - Falta de ração - risco de mortandade de animais. Disponível em: <http://abpa-

br.com.br/noticia/nota-a-imprensa-falta-de-racao-risco-de-mortandade-de-animais-2451>. Acesso em: 16 nov. 2018.

ATKINS, P. W.; JONES, L. Princípios de química: questionando a vida moderna e o meio ambiente. Porto Alegre: Bookman, 2012.

ATMAVEG. Você sabe o que é ser vegano? Disponível em:

<https://www.atmaveg.com/veganismo>. Acesso em: 16 nov. 2018.

AZEVEDO, E. Vegetarianismo. Demetra, v. 8, n. 1, p. 275-288, 11 set. 2013.

AZEVEDO, E. O ativismo alimentar na perspectiva do locavorismo. Ambiente e Sociedade, v. XVIII, n. 3, p. 81-98, 2015.

AZEVEDO, E. Alimentação, sociedade e cultura: temas contemporâneos. Sociologias, v. 19, n. 44, p. 276-307, 2017.

BAILEY, R.; FROGGATT, A.; WELLESLEY, L. Livestock - climate change's forgotten sector: global public ppinion on meat and dairy consumption. Londres: Chatham House, 2014.

BAIRD, C.; CANN, M. Química ambiental. Porto Alegre: Bookman, 2011.

BAJŽELJ, B. et al. Importance of food-demand management for climate mitigation. Nature Climate Change, v. 4, p. 924-929, 31 out. 2014.

BAKER, M. A.; SHIN, J. T.; KIM, Y. W. An exploration and investigation of edible insect consumption: the impacts of image and description on risk perceptions and purchase intent. Psychology \& Marketing, v. 33, n. 2, p. 94-112, 2016.

BANCO NACIONAL DE DESENVOLVIMENTO SOCIAL. Sistema BNDES -

Participações acionárias - Setembro/2018. Disponível em: $<$ https://www.bndes.gov.br/wps/wcm/connect/site/9d797de7-4b8a-4151-9b47e85053f0a860/Carteira+de+ativos+-+2018SET.pdf?MOD=AJPERES\&CVID=mtRrmqd $>$. Acesso em: 16 nov. 2018. 
BAR-ON, Y. M.; PHILLIPS, R.; MILO, R. The biomass distribution on Earth. Proceedings of the National Academy of Sciences of the United States of America, v. 115, n. 25, p. 6506-6511, 19 jun. 2018.

BARONA, E. et al. The role of pasture and soybean in deforestation of the Brazilian Amazon. Environmental Research Letters, v. 5, p. 1-9, 2010.

BARONI, L. et al. Evaluating the environmental impact of various dietary patterns combined with different food production systems. European Journal of Clinical Nutrition, v. 61, n. 2, p. 279-286, 2007.

BARRETO, P. Como reduzir a contribuição da pecuária brasileira para as mudanças climáticas? Belém: PA: Imazon, 2015.

BEARDSWORTH, A.; KEIL, T. The vegetarian option - varieties, concersions, motives, careers.pdf. The Sociological Review, v. 40, n. 2, p. 253-293, 1992.

BECK, U. Risk society: towards a new modernity. Londres: Sage, 1992.

BECKER, M. et al. A Pegada Ecológica de São Paulo - Estado e Capital e a família de pegadas. Brasília: WWF-Brasil, 2012.

BEEF POINT. Qualidade da carne brasileira e o mercado europeu. 2001. Disponível em: <https://www.beefpoint.com.br/qualidade-da-carne-brasileira-e-o-mercado-europeu-3915/>. Acesso em: 20 nov. 2018.

BEEF POINT. PA: boi vivo é o carro chefe das exportações. 2010. Disponível em: <https://www.beefpoint.com.br/pa-boi-vivo-e-o-carro-chefe-das-exportacoes-60218/>. Acesso em: 16 nov. 2018.

BEEF POINT. Conheça todos os produtos que são feitos a partir de bovinos. 2016. Disponível em: <https://www.beefpoint.com.br/conheca-todos-os-produtos-que-sao-feitos-apartir-de-bovinos-infografico/>. Acesso em: 16 jan. 2018.

BEEF POINT. Outra grande processadora de carne investe em proteínas vegetais. 2017a. Disponível em: <https://www.beefpoint.com.br/outra-grande-processadora-de-carne-investeem-proteinas-vegetais/>. Acesso em: 23 nov. 2018.

BEEF POINT. Ex-vegetarianos revelam por que voltaram a comer carne - BeefPoint. 2017b. Disponível em: <https://www.beefpoint.com.br/ex-vegetarianos-revelam-por-quevoltaram-a-comer-carne-novamente/>. Acesso em: 4 nov. 2018.

BERNERS-LEE, M. et al. The relative greenhouse gas impacts of realistic dietary choices. Energy Policy, v. 43, p. 184-190, 1 abr. 2012.

BERTONATTI, C. A confusão do veganismo. 2016. Disponível em: $<$ https://www.beefpoint.com.br/a-confusao-do-veganismo-por-claudio-bertonatti/>. Acesso em: 5 nov. 2018.

BONTEMPO, M. Alimentação para um novo mundo. Rio de Janeiro: Record, 2003. 
BOUVARD, V. et al. Carcinogenicity of consumption of red and processed meat. The Lancet. Oncology, v. 16, n. 16, 2015.

BRIAN, K. The Reducetarian Solution: How the Surprisingly Simple Act of Reducing the Amount of Meat in Your Diet Can Transform Your Health and the Planet, 2017. Disponível em: <https://philpapers.org/rec/KATTRS-2>. Acesso em: 13 dez. 2018

BRITISH BROADCASTING CORPORATION NEWS. Carne vencida e mascarada com "produtos cancerígenos": o escândalo que atinge as maiores empresas do Brasil. 2017. Disponível em: <https://www.bbc.com/portuguese/brasil-39313589>. Acesso em: 18 nov. 2018.

BRÜGGER, P. Educação ou adestramento ambiental? Biotemas, v. 9, n. 2, p. 71-73, 1994.

BRÜGGER, P. Nós e os outros animais: especismo, veganismo e educação ambiental. Linhas Críticas, v. 15, n. 29, p. 197-214, 2009.

Bryant, R. L. and Goodman, M. K. Peopling the practices of sustainable consumption: ecochic and the limits to the spaces of intention. In: Barendregt, B.; Jaffe, R. (eds.) Green Consumption: The Global Rise of Eco-Chic. Londres: Bloomsbury Academic, 2014.

BURLINGAME, B. Sustainable diets and biodiversity: directions and solutions for policy, research and action. Roma: Food and Agriculture Organization of the United Nations - FAO, 2010.

CALLON, M. Society in the Making: The Study of Technology as a Tool for Sociological Analysis. In: BIJKER, W. E.; HUGHES, T. P.; PINCH, T. J. (Eds.). The Social construction of technological systems: new directions in the sociology and history of technology. Londres: MIT Press, 1987.

CALLON, M. Pour une sociologie des controverses technologiques. In: Sociologie de la traduction. Paris: Presses des Mines, 2006. p. 135-157.

CAMBRIDGE DICTIONARY. Meaning of "agriculture" in the English Dictionary. Disponível em:

$<$ https://dictionary.cambridge.org/dictionary/english/agriculture?q=agriculture $>$. Acesso em: 15 nov. 2018.

CAMPELO, L. “O Trabalho Escravo É Uma Realidade Invisível”, Afirma Coordenador Da CPT. 2017. Disponível em: <https://www.brasildefato.com.br/2017/01/05/o-trabalhoescravo-e-uma-realidade-invisivel-afirma-coordenador-da-cpt/>. Acesso em: 18 nov. 2018.

CANTOR, D.; BONAH, C.; DÖRRIES, M. Meat, medicine and human health in the twentieth century. Londres: Pickering \& Chatto, 2010.

CAPARROS MEGIDO, R. et al. Edible insects acceptance by belgian consumers: Promising attitude for entomophagy development. Journal of Sensory Studies, v. 29, n. 1, p. 14-20, 2014.

CAPARROS MEGIDO, R. et al. Consumer acceptance of insect-based alternative meat 
products in Western countries. Food Quality and Preference, v. 52, p. 237-243, 2016.

CAPUTO, L. et al. Environmental Vegetarianism: report di una controversia. Milão, 2012.

CARLSSON-KANYAMA, A.; GONZÁLEZ, A. D. Potential contributions of food consumption patterns to climate change. The American Journal of Clinical Nutrition, v. 89, n. 5, p. 1704S-1709S, 1 maio 2009.

CARNEIRO, H. Comida e sociedade: uma história da alimentação. Rio de Janeiro: Elsevier, 2003.

CARREIRA, D.; RE'EM, A.; TARIN, M. Natural capital risk exposure of the financial sector in Brazil. Trucost, 2015.

CARRIJO, M. C. G. R.; ROCHA, H. J. Carne orgânica: "novos rumos para a pecuária de corte". I Conferência Virtual Global sobre Produção Orgânica de Bovinos de Corte. Concordia: Embrapa, p. 1-6, 2002.

CARVALHO, T. B. Estudo da elasticidade-renda da demanda de carne bovina, suína e de frango no Brasil. Dissertação (Mestrado em Economia Aplicada) - Escola Superior de Agricultura Luiz de Queiroz, Universidade de São Paulo, Piracicaba, 2007.

CARVALHO, T. B.; ZEN, S. DE. A cadeia de Pecuária de Corte no Brasil: evolução e tendências. Revista iPecege, v. 3, n. 1, p. 85, 16 fev. 2017.

CASSIDY, E. S. et al. Redefining agricultural yields: from tonnes to people nourished per hectare. Environmental Research Letters, v. 8, p. 1-8, 2013.

CAVIOLA, L.; EVERETT, J. A. C.; FABER, N. S. The moral standing of animals: Towards a psychology of speciesism. Journal of Personality and Social Psychology, 8 mar. 2018.

CEDERBERG, C. et al. Including carbon emissions from deforestation in the carbon footprint of brazilian beef. Environmental Science and Technology, v. 45, n. 5, p. 1773-1779, 2011.

CHADWICK, D. et al. Manure management: Implications for greenhouse gas emissions. Animal Feed Science and Technology, v. 166-167, p. 514-531, 23 jun. 2011.

CHAVES, F. Gafe: Site do Jornal Hoje mostra receita "vegan" que contém ovos.

Disponível em: <https://www.vista-se.com.br/gafe-site-do-jornal-hoje-mostra-receita-veganque-contem-ovos/>. Acesso em: 20 nov. 2018.

CHAVES, F. A confusão do carnismo - resposta ao artigo que afirma que veganos matam mais animais. Disponível em: <https://www.vista-se.com.br/a-confusao-docarnismo-reposta-ao-artigo-que-afirma-que-veganos-matam-mais-animais/>. Acesso em: 15 nov. 2018.

CHAVES, F. SVB refuta matéria da revista Época Negócios que afirma que o veganismo não é sustentável. Disponível em: <https://www.vista-se.com.br/svb-refuta-materia-darevista-epoca-negocios-que-afirma-que-o-veganismo-nao-e-sustentavel/>. Acesso em: 17 jan. 
2019.

CLEMENS, J. et al. Mitigation of greenhouse gas emissions by anaerobic digestion of cattle slurry. Agriculture, Ecosystems \& Environment, v. 112, n. 2-3, p. 171-177, 1 fev. 2006.

COHEN, T. In the land of milk and honey, Israelis turn vegan. Disponível em: $<$ https://www.reuters.com/article/us-israel-food-vegan/in-the-land-of-milk-and-honeyisraelis-turn-vegan-idUSKCNOPV1H020150721>. Acesso em: 15 jan. 2019.

COLLINS, H. M.; PINCH, T. The golem: what everyone should know about science. Cambridge: Cambridge University Press, 1998.

CONSELHO REGIONAL DE NUTRICIONISTAS. Parecer Técnico CRN-3 Nº 11/2015. São Paulo: Conselho Regional de Nutricionistas, 2015.

COOK, J. et al. Quantifying the consensus on anthropogenic global warming in the scientific literature. Environ. Res. Lett. n. 8, p. 1-7, 2013.

COSTA, G. N. Dietas alimentares e as emissões de gases de efeito estufa nas capitais brasileiras. Dissertação (Mestrado em Economia) - Centro de Ciências em Gestão e Tecnologia Programa, Universidade Federal de São Carlos, Sorocaba, 2018.

COWSPIRACY: O segredo da sustentabilidade. Direção, roteiro e produção: Kip Andersen, Keegan Kuhn. Intérpretes: Lisa Agabian, Manucher Alemi, Lindsey Allen e outros. Estados Unidos: A.U.M Films, 2014. Widescreen, color. Produzido por A.U.M Films (91 min).

CUNHA, J. JBS dobra lucro em ano de crise e diz que quer ser referência em transparência. Disponível em: <https://www1.folha.uol.com.br/mercado/2018/04/jbs-dobralucro-em-ano-de-crise-e-diz-que-quer-ser-referencia-em-transparencia.shtml>. Acesso em: 16 jan. 2019.

DAGEVOS, H.; VOORDOUW, J. Sustainability and meat consumption: Is reduction realistic? Sustainability: Science, Practice, and Policy, v. 9, n. 2, p. 60-69, 2013.

DAVIS, J. The vegetus myth. Disponível em: <http://www.vegsource.com/john-davis/thevegetus-myth.html>. Acesso em: 10 nov. 2018.

DE BACKER, C. J. S.; HUDDERS, L. From Meatless Mondays to Meatless Sundays: Motivations for Meat Reduction among Vegetarians and Semi-vegetarians Who Mildly or Significantly Reduce Their Meat Intake. Ecology of Food and Nutrition, v. 53, n. 6, 2014.

DE BOER, J.; DE WITT, A.; AIKING, H. Help the climate, change your diet: A crosssectional study on how to involve consumers in a transition to a low-carbon society. Appetite, v. 98, p. 19-27, 1 mar. 2016.

DE BOER, J.; SCHÖSLER, H.; AIKING, H. “Meatless days" or "less but better”? Exploring strategies to adapt Western meat consumption to health and sustainability challenges.

Appetite, v. 76, p. 120-128, 2014.

DELGADO, C. L. et al. Livestock to 2020: the next food revolution. Washington, D.C.: 
International Food Policy Research Institute, 1999.

DELGADO, C. L. Rising Consumption of Meat and Milk in Developing Countries Has Created a New Food Revolution. The Journal of Nutrition, v. 133, n. 11, p. 3907S-3910S, 1 nov. 2003.

DEPARTAMENTO INTERSINDICAL DE ESTATÍSTICA E ESTUDOS SOCIOECONÔMICOS. Impactos da operação carne fraca sobre o setor pecuário e os empregos. 2017. Disponível em:

<https://www.dieese.org.br/notatecnica/2017/notaTec176CarneFraca.pdf >. Acesso em: 15 nov. 2018.

DIAS, J. V. G. O Rigor da Morte: a Construção Simbólica do "Animal de Açougue" na Produção Industrial Brasileira. Dissertação (Mestrado em Antropologia Social) Departamento de Antropologia Social, Instituto de Filosofia e Ciências Humanas, Universidade Estadual de Campinas, Campinas, 2009.

DICIO. Significado de gado. Disponível em: <https://www.dicio.com.br/gado/>. Acesso em: 23 nov. 2018.

DOMINGUES, M. S.; BERMANN, C. O arco de desflorestamento na Amazônia: da pecuária à soja. Ambiente \& Sociedade, v. 15, n. 2, p. 1-22, ago. 2012.

DREWNOWSKI, A.; SPECTER, S. E. Poverty and obesity : the role of energy density and energy costs. The American Journal of Clinical Nutrition, v. 79, p. 6-16, 2004.

EATING BETTER. Principles for eating meat and dairy more sustainably: the 'less and better' approach. Eating Better, 2018.

ECHER, R. et al. Usos da terra e ameaças para a conservação da biodiversidade no bioma Pampa , Rio Grande do Sul. Thema, v. 12, n. 02, p. 4-13, 2015.

EMPRESA BRASILEIRA DE PESQUISA AGROPECUÁRIA; INSTITUTO NACIONAL DE PESQUISAS ESPACIAIS. Levantamento de informações de uso e cobertura da terra na Amazônia. Brasília: Empresa Brasileira de Pesquisa Agropecuária: Instituto Nacional de Pesquisas Espaciais, 2011.

EMPRESA BRASILEIRA DE PESQUISA AGROPECUÁRIA. Lavouras são apenas 7,6\% do Brasil, segundo a NASA. 2017. Disponível em:

$<$ https://www.embrapa.br/web/portal/territorial/busca-de-noticias//noticia/30972444/lavouras-sao-apenas-76-do-brasil-segundo-a-nasa>. Acesso em: 11 nov. 2018.

EMPRESA BRASILEIRA DE PESQUISA AGROPECUÁRIA. Animais criados livres no Pampa fornecem carne mais saudável. 2018. Disponível em: $<$ https://www.embrapa.br/busca-de-noticias/-/noticia/36742971/animais-criados-livres-nopampa-fornecem-carne-mais-saudavel>. Acesso em: 20 nov. $2018 \mathrm{a}$.

EMPRESA BRASILEIRA DE PESQUISA AGROPECUÁRIA. Pastagem. Disponível em: $<$ https://www.embrapa.br/qualidade-da-carne/carne-bovina/producao-de-carne- 
bovina/pastagem>. Acesso em: 15 dez. $2018 \mathrm{~b}$.

ERB, K.-H. et al. Exploring the biophysical option space for feeding the world without deforestation. Nature Communications, v. 7, n. 1, p. 11382, 19 dez. 2016.

ESHEL, G. et al. Diet, Energy, and Global Warming. Earth Interactions, v. 10, n. 9, p. 1-17, 2006.

ESHEL, G. et al. Land, irrigation water, greenhouse gas, and reactive nitrogen burdens of meat, eggs, and dairy production in the United States. Proceedings of the National Academy of Sciences, v. 111, n. 33, p. 11996-12001, 2014.

ESTEVE, E. V. O negócio da comida: quem controla nossa alimentação? São Paulo: Expressão Popular, 2017.

ETMINAN, M. et al. Radiative forcing of carbon dioxide, methane, and nitrous oxide: a significant revision of the methane radiative forcing. Geophysical Research Letters, v. 43, n. 24, p. 12.614-12.623, 28 dez. 2016.

EVANS-PRITCHARD, E. E. Os Nuer: uma descrição do modo de subsistência e das instituições políticas de um povo nilota., 2008. Disponível em:

<http://www.academia.edu/8136675/Os_Nuer._Evans-Pritchard>. Acesso em: 16 nov. 2018

FARM ANIMAL INVESTMENT RISK \& RETURN. The livestock levy: are regulators considering meat taxes? Farm Animal Investment Risk \& Return - FAIRR, 2017.

FGV. Crise e Castigo: a delação da JBS. Rio de Janeiro: FGV, 2017.

FISCHLER, C. L'homnivore: le goût, la cuisine et le corps. Paris: Odile Jacob, 1990.

FOER, J. S. Eating animals. Nova Iorque: Little, Brown and Company, 2009.

FOLEY, J. A. et al. Solutions for a cultivated planet. Nature, v. 478, p. 337-42, 2011.

FONT-I-FURNOLS, M.; GUERRERO, L. Consumer preference, behavior and perception about meat and meat products: an overview. Meat Science, v. 98, n. 3, p. 361-371, 2014.

FOOD AND AGRICULTURE ORGANIZATION OF THE UNITED NATIONS.

Livestock's long shadow: environmental issues and options. Roma: Food and Agriculture Organization of the United Nations, 2006.

FOOD AND AGRICULTURE ORGANIZATION OF THE UNITED NATIONS. Forest insects as food: humans bite back. Tailândia: Food and Agriculture Organization of the United Nations, 2010.

FOOD AND AGRICULTURE ORGANIZATION OF THE UNITED NATIONS. World Livestock 2011: Livestock in food security. Roma: Food and Agriculture Organization of the United Nations, 2011.

FOOD AND AGRICULTURE ORGANIZATION OF THE UNITED NATIONS. Tackling 
Climate Change Through Livestock: A global assessment of emissions and mitigation opportunities. Roma: Food and Agriculture Organization of the United Nations, 2013a.

FOOD AND AGRICULTURE ORGANIZATION OF THE UNITED NATIONS. The contribution of insects to food security, livelihoods and the environment. 2013b.

Disponível em: <http://www.fao.org/docrep/018/i3264e/i3264e00.pdf>. Acesso em: 16 nov. 2018b.

FOOD AND AGRICULTURE ORGANIZATION OF THE UNITED NATIONS. EI Estado de los bosques del mundo. Roma: Food and Agriculture Organization of the United Nations, 2016.

FOOD AND AGRICULTURE ORGANIZATION OF THE UNITED NATIONS. FAOSTAT. Current Worldwide Annual Meat Consumption per capita: Livestock and Fish Primary Equivalent. 2013c. Disponível em: 〈http://www.fao.org/faostat/en/\#data/CL〉. Acesso em: 15 nov. $2018 \mathrm{c}$.

FOOD AND AGRICULTURE ORGANIZATION OF THE UNITED NATIONS.

FAOSTAT. Livestock Primary Data. Disponível em:

<http://www.fao.org/faostat/en/\#data>. Acesso em: 15 nov. 2018.

FOX, M. A. Vegetarianism and planetary health. Ethics and the Environment, v. 5, n. 2, p. 163-174, 2000.

FOX, N.; WARD, K. Health, ethics and environment: a qualitative study of vegetarian motivations. Appetite, v. 50, p. 422-429, mar. 2008.

FRANCIONE, G. L. Animals as persons: essays on the abolition of animal exploitation. Nova Iorque: Columbia University Press, 2008.

FREIRE, L. D. L. Seguindo Bruno Latour: notas para uma antropologia simétrica. Comum, v. 11, n. 26, p. 46-65, 2006.

FUNDAÇÃO BRASILEIRA PARA O DESENVOLVIMENTO SUSTENTÁVEL.

Desmatamento na amazônia: desafios para reduzir as emissões brasileiras. Fundação Brasileira para o Desenvolvimento Sustentável - FBDS, 2010.

GAARD, G. C. Vegetarian ecofeminism: a review essay. Frontiers: A Journal of Women Studies, v. 23, n. 3, p. 117-146, 2002.

GAIMAN, N. Sandman: um sonho de mil gatos. Brain Store, 2002.

GALAZ, V. et al. Tax havens and global environmental degradation. Nature Ecology \& Evolution, v. 2, n. 9, p. 1352-1357, 13 set. 2018.

GALE, C. R. et al. IQ in childhood and vegetarianism in adulthood: 1970 British cohort study. British Medical Journal, v. 334, n. 7587, p. 245-248, 2007.

GAZZANIGA, M. Who's in Charge?: Free Will and the Science of the Brain. Londres: Constable \& Robinson, 2012. 
GEORGE, K. P. Animal, vegetable, or woman?: a feminist critique of ethical vegetarianism. Nova Iorque: State University of New York Press, 2000.

GERBER, P. J. et al. Mitigation of greenhouse gas emissions in livestock production : a review of technical options for non- $\mathrm{CO}_{2}$ emissions. Roma: Food and Agriculture Organization of the United Nations, 2013.

GILL, M.; SMITH, P.; WILKINSON, J. M. Mitigating climate change: the role of domestic livestock. The Animal Consortium, v. 4, n. 03, p. 323-333, 22 mar. 2009.

GIROD, B.; VAN VUUREN, D. P.; HERTWICH, E. G. Climate policy through changing consumption choices: Options and obstacles for reducing greenhouse gas emissions. Global Environmental Change, v. 25, n. 1, p. 5-15, 2014.

GLOBAL CHALLENGES FOUNDATION. Global catastrophic risks 2018. Estocolmo: Global Challenges Foundation, 2018.

GODFRAY, H. C. J. et al. Food security: the challenge of feeding 9 billion people. Science, v. 327, n. 5967, p. 812-818, 2010.

GOLDIM, J. R. Princípio da Precaução. Disponível em:

<https://www.ufrgs.br/bioetica/precau.htm>. Acesso em: 20 nov. 2018.

GOMES, L. B. M. A postura ética vegetariana frente à contemporânea exploração dos animais não humanos. Trabalho de Conclusão de Curso (Bacharelado em História) Instituto de História, Universidade Federal de Uberlândia, Uberlândia, 2006.

GOODLAND, R.; ANHANG, J. Livestock and climate change: what if the key actors in climate change are... cows, pigs, and chickens? World Watch Institute, p. 10-19, 2009.

GOSDEN, E. Lettuce "three times worse than bacon" for the environment, scientists claim. Disponível em:

$<$ https://www.telegraph.co.uk/news/earth/environment/12052711/Lettuce-worse-than-baconfor-the-environment-scientists-claim.html>. Acesso em: 7 dez. 2018.

GREEN, R. et al. The potential to reduce greenhouse gas emissions in the UK through healthy and realistic dietary change. Climatic Change, v. 129, n. 1-2, p. 253-265, 26 mar. 2015.

GREIF, S. Sustentabilidade econômica e ecológica mediante a opção pelo vegetarianismo. Cadernos de Debate, v. IX, p. 55-69, 2002.

GROTZINGER, J.; JORDAN, T. H. Understanding Earth. Nova Iorque: W.H. Freeman and Company, 2014. v. 18

GUIDOTTI, V. et al. A funcionalidade da agropecuária brasileira (1975 a 2020).

Sustentabilidadeem Debate, n. 2, p. 11, 2015.

HAACK, M. D. S. Análise de materiais por espectroscopia no infravermelho dentro do sistema de gestão de qualidade conforme ABNT NBR ISO/IEC 17025. Journal of Chemical Information and Modeling, v. 53, n. 9, p. 1689-1699, 2010. 
HAKKUNA. Hakkuna. Disponível em: <http://hakkuna.com/>. Acesso em: 16 dez. 2018.

HAMERSCHLAG, K. Meat Eater's Guide to Climate and Health. Environmental Working Group, 2011.

HARARI, Y. N. Sapiens: uma breve história da humanidade. Porto Alegre: L\&PM, 2017.

HARAWAY, D. A partilha do sofrimento: relações instrumentais entre animais de laboratório e sua gente. Horizontes Antropológicos, v. 17, n. 35, p. 27-64, jun. 2011.

HARRIS, M. Canibais e reis. Lisboa: Edições 70, 1990.

HARTMANN, C.; SIEGRIST, M. Consumer perception and behaviour regarding sustainable protein consumption: A systematic review. Trends in Food Science and Technology, v. 61, p. 11-25, 2017.

HAYES, J. R. et al. Multiple-Antibiotic Resistance of Enterococcus spp. Isolated from Commercial Poultry Production Environments. Society, v. 70, n. 10, p. 6005-6011, 2004.

HEDENUS, F.; WIRSENIUS, S.; JOHANSSON, D. J. A. The importance of reduced meat and dairy consumption for meeting stringent climate change targets. Climatic Change, v. 124, n. 1-2, p. 79-91, 28 maio 2014.

HEINRICH BÖLL FOUNDATION. Meat atlas: facts and figures about the animals we eat. Berlim: Heinrich Böll Foundation, 2014.

HEINRICH BÖLL FOUNDATION. Atlas da carne: fatos e números sobre os animais que comemos. Rio de Janeiro: Heinrich Böll Foundation, 2015.

HENDERSON, B. B. et al. Greenhouse gas mitigation potential of the world's grazing lands: Modeling soil carbon and nitrogen fluxes of mitigation practices. Agriculture, Ecosystems \& Environment, v. 207, p. 91-100, set. 2015.

HERRERO, M. et al. Livestock and greenhouse gas emissions: The importance of getting the numbers right. Animal Feed Science and Technology, v. 166-167, p. 779-782, 2011.

HERRERO, M. et al. Livestock and the Environment: What Have We Learned in the Past Decade? Annu. Rev. Environ. Resour., v. 40, p. 177-202, 2015.

HERTWICH, E. G.; VAN DER VOET, E.; TUKKER, A. Assessing the environmental impacts of consumption and production: priority products and materials. Paris: United Nations Environment Programme, 2010.

HILL, I. D. Segurança alimentar: palavra de ordem para a pecuária. Disponível em: $<$ https://www.agrolink.com.br/colunistas/coluna/seguranca-alimentar--palavra-de-ordempara-a-pecuaria_384984.html>. Acesso em: 16 nov. 2018.

HOCQUETTE, J. F. Is in vitro meat the solution for the future? Meat Science, v. 120, p. 167-176, 2016. 
HOEKSTRA, A. Y.; MEKONNEN, M. M. The water footprint of humanity. Proceedings of the national academy of sciences, v. 109, n. 9, p. 3232-3237, 2012.

HOFFMAN, S. R. et al. Differences between health and ethical vegetarians. Strength of conviction, nutrition knowledge, dietary restriction, and duration of adherence. Appetite, v. 65, p. 139-144, 2013.

HUANG, J.; BOUIS, H. Structural changes in the demand for food in Asia. International Food Policy Research Institute, 1996.

HUNT, J. R. Bioavailability of iron, zinc, and other trace minerals from vegetarian diets. The American journal of clinical nutrition, v. 78, n. 3 Suppl, p. 633S-639S, set. 2003.

IGUALDAD ANIMAL. México, el país con más vegetarianos en Latinoamérica. Disponível em: <http://www.igualdadanimal.org/noticias/7611/mexico-el-pais-con-masvegetarianos-en-latinoamerica $>$. Acesso em: 15 jan. 2019.

INGOLD, T. Hunters, pastoralists, and ranchers: reindeer economies and their transformations. Cambridge: Cambridge University Press, 1988.

INGOLD, T. Humanidade e Animalidade. 1995. Disponível em: <http://www.biolinguagem.com/ling_cog_cult/ingold_1994_humanidade_animalidade.pdf >. Acesso em: 12 nov. 2018.

INGOLD, T. Being alive: essays on movement, knowledge and description. Londres: Routledge, 2011.

INSTITUTO BRASILEIRO DE GEOGRAFIA E ESTATÍSTICA. Área por atividade econômica no Brasil. Disponível em:

<https://brasilemsintese.ibge.gov.br/agropecuaria/atividade-economica-area.html >. Acesso em: 11 nov. 2018.

INSTITUTO BRASILEIRO DE GEOGRAFIA E ESTATÍSTICA. Produto interno bruto dos municípios : 2010-2013. Rio de Janeiro: Instituto Brasileiro de Geografia e Estatística IBGE, 2015.

INSTITUTO BRASILEIRO DE GEOGRAFIA E ESTATÍSTICA. Estimativas de

População. Disponível em: <https://www.ibge.gov.br/estatisticasnovoportal/sociais/populacao/9103-estimativas-depopulacao.html?edicao=16985\&t=resultados $>$. Acesso em: 15 nov. 2018.

INSTITUTO BRASILEIRO DE OPINIÃO PÚBLICA E ESTATÍSTICA. Dia Mundial do Vegetarianismo: $8 \%$ da população brasileira afirma ser adepta do estilo. Disponível em: $<$ http://www.ibope.com.br/pt-br/noticias/Paginas/Dia-Mundial-do-Vegetarianismo-8-dapopulacao-brasileira-afirma-ser-adepta-ao-estilo.aspx>. Acesso em: 21 fev. 2017.

INSTITUTO BRASILEIRO DE OPINIÃO PÚBLICA E ESTATÍSTICA. 14\% da população se declara vegetariana | IBOPE Inteligência. Disponível em:

$<$ http://www.ibopeinteligencia.com/noticias-e-pesquisas/14-da-populacao-se-declaravegetariana/>. Acesso em: 3 nov. 2018. 
INSTITUTO DE MANEJO E CERTIFI CAÇÃO FLORESTAL E AGRÍCOLA. Evolução das emissões setor de agropecuária no Brasil (1970-2013) de gases de efeito estufa. São Paulo: Instituto de Manejo e Certificação Florestal e Agrícola - Imaflora, 2015.

INTERGOVERNMENTAL PANEL ON CLIMATE CHANGE: Annex II: Glossary. Mach, K.J., S. Planton and C. von Stechow (eds.). In: Climate Change 2014: Synthesis Report. Contribution of Working Groups I, II and III to the Fifth Assessment Report of the Intergovernmental Panel on Climate Change [Core Writing Team, R.K. Pachauri and L.A. Meyer (eds.)]. IPCC, Geneva, Switzerland, pp. 117-130.

INTERGOVERNMENTAL PANEL ON CLIMATE CHANGE. Mitigation of Climate Change Working. Nova Iorque: Cambridge University Press, 2014b.

INTERGOVERNMENTAL PANEL ON CLIMATE CHANGE. Annex II: Glossary. Disponível em: <https://www.ipcc.ch/pdf/assessmentreport/ar5/syr/AR5_SYR_FINAL_Glossary.pdf>. Acesso em: 30 nov. 2018c.

INTERGOVERNMENTAL PANEL ON CLIMATE CHANGE. Direct Global Warming Potentials. Disponível em: <https://www.ipcc.ch/publications_and_data/ar4/wg1/en/ch2s210-2.html>. Acesso em: 14 jul. 2017.

INTERNATIONAL LIVESTOCK RESEARCH INSTITUTE. Mapping of poverty and likely zoonoses hotspots. International Livestock Research Institute - ILRI, 2012.

JABS, J.; DEVINE, C. M. Time scarcity and food choices: An overview. Appetite, v. 47, n. 2, p. 196-204, 2006.

JACKSON, C. R. et al. Effects of tylosin use on erythromycin resistance in enterococci isolated from swine. Applied and Environmental Microbiology, v. 70, n. 7, p. 4205-4210, 2004.

JACOBI, P. Meio Ambiente e Sustentabilidade. n. 1993, p. 175-183, 1996.

JAIN, J. C. Jainismo: vida e obra de Mahavira Vardhamana. São Paulo: Palas Athena, 1982.

JAMIESON, A. UN admits flaw in report on meat and climate change. Disponível em: $<$ https://www.telegraph.co.uk/news/earth/environment/climatechange/7509978/UN-admitsflaw-in-report-on-meat-and-climate-change.html>. Acesso em: 30 nov. 2018.

JANSSEN, M. et al. Motives of consumers following a vegan diet and their attitudes towards animal agriculture. Appetite, v. 105, p. 643-51, 1 out. 2016.

JONY, E.; RIBEIRO, J.; FRACALOSSI DE MORAES, R. De BRIC a BRICS: como a África do Sul ingressou em um clube de gigantes. Boletim de Economia e Política Internacional, n. 10, 2012.

JOY, M. Why we love dogs, eat pigs, and wear cows: an introduction to carnism. Massachusetts: Conari Press, 2010.

KAIMOWITZ, D. et al. Hamburger connection fuels Amazon desctruction : cattle ranching 
and deforestation in Brazil's Amazon. Center for International Forestry Research, p. 1-10, 2017.

KANALY, R. A. et al. Energy Flow, Environment and Ethical Implications for Meat Production. Bangkok: UNESCO, 2010.

KAPLAN, H. et al. A theory of human life history evolution: Diet, intelligence, and longevity. Evolutionary Anthropology: Issues, News, and Reviews, v. 9, n. 4, p. 156-185, 1 jan. 2000.

KEY, T. J.; APPLEBY, P. N.; ROSELL, M. S. Health effects of vegetarian and vegan diets. Proceedings of the Nutrition Society, v. 65, p. 35-41, 2006.

KIRINUS, J. et al. Relação entre faixas de renda e o perfil dos consumidores de carne bovina da região sul do Brasil. Revista Monografias Ambientais, v. 12, n. 12, p. 2776-2784, 30 ago. 2013.

KOCHHAR, R. The vedic people: their history and geography. Hyderabad: Orient Longman, 2000 .

LACOUR, C. et al. Environmental Impacts of Plant-Based Diets: How Does Organic Food Consumption Contribute to Environmental Sustainability? Frontiers in Nutrition, v. 5, n. February, p. 1-13, 2018.

LAESTADIUS, L. I. et al. "We don't tell people what to do": An examination of the factors influencing NGO decisions to campaign for reduced meat consumption in light of climate change. Global Environmental Change, v. 29, 2014.

LAHSEN, M. Buffers against inconvenient knowledge: Brazilian newspaper representations of the climate-meat link. Desenvolvimento e Meio Ambiente, v. 40, p. 17-35, 2017.

LAMIM-GUEDES, V. Teias ecológicas, consumo de carne e de calorias. Educação Ambiental em Ação, n. 41, 2012.

LAPLANE, M.; SARTI, F. Prometeu Acorrentado: o Brasil na indústria mundial no início do século XXI. Política Econômica em Foco, n. 7, p. 271-291, 2005.

LAPPÉ, F. M. Diet for a small planet. Nova Iorque: Ballantine Books, 1982.

LAROUSSE DICTIONNAIRE. Agriculture. Disponível em:

<https://www.larousse.fr/dictionnaires/francais/agriculture/1773?q=agriculture\#1778>. Acesso em: 15 nov. 2018.

LARSSON, S. C.; ORSINI, N. Red meat and processed meat consumption and all-cause mortality: a meta-analysis. American Journal of Epidemiology, v. 179, n. 3, p. 282-289, 2013.

LATOUR, B. A esperança de Pandora: Ensaiois sobre a relidade dos estudos cientificos. 1. ed. Bauru: EDUSC, 2001. 
LATOUR, B. Reassembling the Social: an introduction to Actor-Network-Theory. 1. ed. Hampshire: Oxford, 2005.

LATOUR, B. Jamais fomos modernos. Rio de Janeiro: Editora 34, 2009.

LAW, J. Technology and Heterogeneous Engineering: The Case of Portuguese

Expansion. Disponível em:

<https://books.google.com.br/books/about/Technology_and_Heterogeneous_Engineering.htm 1?id=y_XgYgEACAAJ\&redir_esc=y>. Acesso em: 20 jan. 2019.

LAW, J.; HASSARD, J. Actor network theory and after. 1. ed. Nova Jersey: WileyBlackwell, 1999.

LAWRENCE, V. Is vegetarianism a diet or an ideology? Cmaj, v. 148, n. 6, p. 998-1002, 1993.

LEITE, J. C. Controvérsias na climatologia: o IPCC e o aquecimento global antropogênico. Scientiae Studia, v. 13, n. 3, p. 643-677, 2015.

LEROY, F.; PRAET, I. Meat traditions. The co-evolution of humans and meat. Appetite, v. 90, p. 200-211, 2015.

LEWGOY, B. ; SORDI, Caetano . As guerras da carne: o consumo carnívoro, seus defensores e críticos: novas e velhas configurações. In: STEIL, C.A.; CARVALHO, Isabel. (Org.). Cultura, Percepção e Ambiente: diálogos com Tim Ingold. São Paulo: Terceiro Nome, 2012, v. , p. 137-151.

LIMA, R. P. Crescimento das exportações de carne bovina brasileira entre 2005 e 2015: fatores econômicos. Dissertaçao (Mestrado em Economia) - Faculdade de Administração, Ciências Contábeis e Economia, Universidade Federal de Goiás, Goiânia, 2018.

LINDEMAN, M.; SIRELIUS, M. Food choice ideologies: the modern manifestations of normative and humanist views of the world. Appetite, v. 37, p. 175-184, 2001.

LISBOA, M. V. Violência institucional e globalização econômica: o caso brasileiro. Projeto História, n. 38, p. 231-244, 2009.

LOBATO, A. C.; LAGO, R. M. Ensinando a Química do Efeito Estufa no Ensino Médio: Possibilidades e Limites. Quimica Nova na Escola, v. 31, n. 2001, 2004.

LOBATO, L. et al. Planeamento de refeições vegetarianas para crianças em restauração coletiva: princípios base. Lisboa: Programa Nacional para a Promoção da Alimentação Saudável, 2016.

LOCATELLI, P. Pastelarias cariocas e empresa de comida do Rock in Rio estão em nova atualização da lista suja e do trabalho escravo. Disponível em:

$<$ https://reporterbrasil.org.br/2018/04/pastelarias-cariocas-e-empresa-de-comida-do-rock-inrio-estao-em-nova-atualizacao-da-lista-suja-do-trabalho-escravo/>. Acesso em: 18 nov. 2018.

LOCK, K. et al. Health, agricultural, and economic effects of adoption of healthy diet 
recommendations. Lancet, v. 376, p. 1699-1709, 2010.

LOPES, A. Consumo alimentar sustentável: vegetarianismo e omnivorismo. Concurso de Mérito Académico do Centro Vegetariano, p. 1-16, 2013.

LYRA, A. R. T. C. Secretaria de Inspeção do Trabalho - SIT/MTE registra um aumento de 10,39\% no número de trabalhadores em situação análoga à de escravo em 2012. Brasília: Secretaria de Inspeção do Trabalho, 2012.

MACDIARMID, J. I. Is a healthy diet an environmentally sustainable diet? Proceedings of the Nutrition Society, v. 72, n. 1, p. 13-20, 2013.

MACEDO, E. U. História da Índia: uma narrativa do Vale do Rio Indo a

Chandrayaaan-1. Carolina do Sul: Amazon Independent Publishing, 2017.

MACHADO, M. Doação ou investimento? A atuação legislativa dos parlamentares da bancada ruralista e a questão do financiamento de campanhas. Monografia (Graduação em Ciência Política) - Instituto de Ciência Política, Universidade de Brasília, 2013.

MACHOVINA, B.; FEELEY, K. J.; RIPPLE, W. J. Biodiversity conservation: The key is reducing meat consumption. Science of the Total Environment, v. 536, p. 419-431, 2015.

MACIEL, M. E. Churrasco à gaúcha. Horizontes antropológicos, v. 2, n. 4, p. 34-48, 1996.

MADURO, A. E. V. V. Tecnologia e economia agrícola no território alcobacense: séculos XVII-XX. Tese (Doutorado em História) - Faculdade de Letras, Universidade de Coimbra, Coimbra, 2007.

MALUF, R. S.; MENEZES, F. Caderno "Segurança Alimentar”, Conselho Nacional de Segurança Alimentar e Nutricional, 2004.

MAMONA, K. Marfrig dispara após venda bilionária para dona da Friboi. Disponível em: <https://exame.abril.com.br/mercados/marfrig-dispara-apos-venda-bilionaria-para-donada-friboi/>. Acesso em: 16 nov. 2018.

MARÇAL, D. A. et al. Consumo da carne suína no Brasil: Aspectos simbólicos como determinantes dos comportamentos. Revista em Agronegocio e Meio Ambiente, v. 9, n. 4, p. 989-1005, 2016.

MARLOW, H. J. et al. Diet and the environment: does what you eat matter? The American Journal of Clinical Nutrition, v. 89, n. 5, p. 1699S-1703S, 1 maio 2009.

MARRAS, S. Virada animal, virada humana: outro pacto. Scientiae Studia, p. 215-260, 2014.

MARTINKO, K. The meat industry should be worried, food policy expert says. Disponível em: <https://www.treehugger.com/green-food/meat-industry-should-be-worriedfood-policy-expert-says.html>. Acesso em: 16 jan. 2019.

MATASSA, S.; BOON, N.; PIKAAR, I. Microbial protein : Future sustainable food supply 
route with low Microbial protein : future sustainable food supply route with low environmental footprint. Microbial Biotechnology, v. 0, p. 1-8, 2016.

MATURANA, M. V. G. Indústria da carne: degradação do meio ambiente e da vida animal. Monografia (Especialização em Direito Ambiental) - Departamento de Economia Rural e Extensão, Setor de Ciências Agrárias, Universidade Federal do Paraná, Curitiba, 2015.

MAZOYER, M.; ROUDART, L. História das agriculturas no mundo: do neolítico à crise contemporânea. São Paulo: Editora Unesp, 2010.

MEDEIROS, M. L. DE. Quais as influências para as pessoas adotarem o estilo de vida vegano. Trabalho de Conclusão de Curso (Graduação em Administração de Empresas) Pontifícia Universidade Católica, Rio de Janeiro, 2017.

MEDEIROS, S. R. Valor nutricional da carne bovina e suas implicações para a saúde humana. Campo Grande: Embrapa Gado de Corte, 2008.

MEKONNEN, M. M.; HOEKSTRA, A. Y. A global assessment of the water footprint of farm animal products. Ecosystems, v. 15, p. 401-415, 2012.

MELADO, J. Pastagem Ecológica e serviços ambientais da pecuária sustentável. Revista Brasileira de Agroecologia, v. 2, n. 2, p. 1777-1783, 2007.

MELINA, V.; CRAIG, W.; LEVIN, S. Position of the Academy of Nutrition and Dietetics: Vegetarian Diets. Journal of the Academy of Nutrition and Dietetics, v. 116, n. 12, p. 1970-1980, 2016.

MERCY FOR ANIMALS. O guia vegetariano. 2016. Disponível em: <https://escolhaveg.com.br/vsg>. Acesso em: 10 nov. 2018.

MICHELINI, J.; LAHSEN, M. Implicações da pecuária brasileira para a segurança alimentar : a ciência e o discurso do setor produtivo. Sustentabilidade em Debate, v. 7, n. 3, p. 112-126, 2016.

MINISTÉRIO DA CIÊNCIA, TECNOLOGIA, INOVAÇÕES E COMUNICAÇÕES. Estimativas anuais de emissões de gases de efeito estufa no Brasil. Brasília: Ministério da Ciência, Tecnologia, Inovações e Comunicações, 2017.

MINISTÉRIO DA PREVIDÊNCIA SOCIAL; MINISTÉRIO DO TRABALHO E EMPREGO. Anuário Estatístico de Acidentes do Trabalho. Disponível em: $<$ http://www.previdencia.gov.br/dados-abertos/aeat-2009-anuario-estatistico-de-acidentes-dotrabalho-2009/>. Acesso em: 18 nov. 2018.

MINISTÉRIO DA SAÚDE. Guia Alimentar para a População Brasileira. Brasília: Ministério da Saúde, 2014.

MINISTÉRIO DO MEIO AMBIENTE. Mapas de cobertura vegetal dos biomas brasileiros. Brasília: Ministério do Meio Ambiente, 2007.

MINISTÉRIO DO MEIO AMBIENTE. Plano de ação para prevenção e controle do 
desmamatamento e das queimadas: cerrado. Brasília: Ministério do Meio Ambiente, 2011.

MINSON, J. A.; MONIN, B. Do-Gooder Derogation: Disparaging Morally Motivated Minorities to Defuse Anticipated Reproach. Social Psychological and Personality Science, v. 3, n. 2, p. 200-207, 18 mar. 2012.

MIRANDA, S. H. G. DE. Quantificação dos efeitos das barreiras não-tarifárias sobre as exportações brasileiras de carne bovina. Tese (Doutorado em Economia Aplicada) - Escola Superior de Agricultura Luiz de Queiroz, Universidade de São Paulo, Piracicaba, 2001.

MISHORI, D. Environmental Vegetarianism: Conflicting Principles, Constructive Virtues. Law and Ethics of Human Rights, v. 11, n. 2, p. 253-284, 2017.

MONIN, B. Holier Than Me? Threatening Social Comparison in the Moral Domain. Revue Internationale de Psychologie Sociale, v. 20, n. 1, p. 53-58, 2007.

MONTANARI, M. Comida como cultura. São Paulo: SENAC, 2008.

MORGAN, R. The slow but steady rise of vegetarianism in Australia. Disponível em: <http://www.roymorgan.com/findings/vegetarianisms-slow-but-steady-rise-in-australia201608151105>. Acesso em: 15 jan. 2019a.

MORGAN, R. Vegetarianism on the rise in New Zealand. Disponível em: $<$ http://www.roymorgan.com/findings/6663-vegetarians-on-the-rise-in-new-zealand-june2015-201602080028>. Acesso em: 15 jan. 2019b.

MORGAN, R. Bill Gates and Richard Branson bet on lab-grown meat startup.

Disponível em: <https://www.cnbc.com/2018/03/23/bill-gates-and-richard-branson-bet-onlab-grown-meat-startup.html>. Acesso em: 16 dez. 2018.

MORTARA, A. 'Techno mums' motivations towards vegetarian and vegan lifestyles. Italian Sociological Review, v. 3, n. 3, p. 184-192, 2013.

MULLEE, A. et al. Vegetarianism and meat consumption: A comparison of attitudes and beliefs between vegetarian, semi-vegetarian, and omnivorous subjects in Belgium. Appetite, v. 114, 2017.

NASA. John Tyndall. Disponível em:

<https://www.earthobservatory.nasa.gov/features/Tyndall>. Acesso em: 15 out. 2018.

NATIONAL CENTERS FOR ENVIRONMENTAL INFORMATION. Greenhouse Gases:

Water Vapor. Disponível em: <https://www.ncdc.noaa.gov/monitoring-

references/faq/greenhouse-gases.php?section=watervapor>. Acesso em: 3 dez. 2018.

NETHERLANDS ENVIRONMENTAL ASSESSMENT AGENCY. Rethinking global

biodiversity strategies. Haia: Netherlands Environmental Assessment Agency, 2010.

NIJDAM, D.; ROOD, T.; WESTHOEK, H. The price of protein: Review of land use and carbon footprints from life cycle assessments of animal food products and their substitutes.

Food Policy, v. 37, n. 6, p. 760-770, 1 dez. 2012. 
NOBRE, A. D. O futuro climático da Amazônia: relatório de avaliação científica. São José dos Campos: ARA: CCST-INPE: INPA, 2014.

NOOR, P. Caroline Lucas is wrong - a meat tax would only hurt the poor. Disponível em: <https://www.theguardian.com/commentisfree/2019/jan/07/caroline-lucas-is-wrongmeat-tax-climate-crisis >. Acesso em: 16 jan. 2019.

NUNES, E. L. M. Vegetarianismo além da dieta: ativismo vegano em São Paulo.

Dissertação (Mestrado em Ciências) - Pontifícia Universidade Católica, São Paulo, 2010.

NUTRIKÉO. Les protéines du futur. Disponível em: <http://www.nutrikeo.com/wpcontent/uploads/2016/09/Nutrikeo_Actifs_article_GuideAZ_proteines_futur_2015-0313.pdf>. Acesso em: 14 nov. 2018.

NUWER, R. O que aconteceria se o mundo inteiro virasse vegetariano? Disponível em: <https://www.bbc.com/portuguese/vert-fut-38129638>. Acesso em: 11 dez. 2018.

O'MARA, F. P. The significance of livestock as a contributor to global greenhouse gas emissions today and in the near future. Animal Feed Science and Technology, v. 166-167, p. 7-15, 2011.

O'RIORDAN, T.; STOLL-KLEEMANN, S. The Challenges of Changing Dietary Behavior Toward More Sustainable Consumption. Environment: Science and Policy for Sustainable Development, v. 57, n. 5, p. 4-13, 3 set. 2015.

OBSERVATÓRIO DO CLIMA. Emissões de GEE do Brasil e suas implicações para políticas públicas e a contribuição brasileira para o acordo de Paris. Observatório do Clima, 2017.

OBSERVATÓRIO DO CLIMA. Rebanho bovino responde por $17 \%$ das emissões de gases de efeito estufa no Brasil. Disponível em:

$<$ http://www.observatoriodoclima.eco.br/rebanho-bovino-responde-por-17-das-emissoes-degases-de-efeito-estufa-no-brasil/>. Acesso em: 2 dez. 2018 .

OBSERVATÓRIO DO CLIMA. Metodologia. Disponível em:

$<$ http://seeg.eco.br/metodologia/>. Acesso em: 1 dez. 2018 b.

ODUM, E. P.; BARRETT, G. W. Fundamentos de Ecologia. São Paulo: Cengage Learnin, 2008.

OMETTO, J. G. S. Apoio à Agropecuária e à Segurança Alimentar. Disponível em: $<$ http://domtotal.com/direito/pagina/detalhe/30419/apoio-a-agropecuaria-e-a-segurancaalimentar>. Acesso em: 16 nov. 2018.

ONG REPÓRTER BRASIL. Moendo gente: a siatuação nos frigoríficos. São Paulo: ONG Repórter Brasil, 2013.

OPEN SOCIETY INSTITUTE. The price of silence: the growing threat of soft censorship in Latin America. Nova Iorque: Open Society Institute, 2008. 
ORGANIZAÇÃO DAS NAÇÕES UNIDAS PARA A EDUCAÇÃO A CIÊNCIA E A CULTURA. Declaração Universal dos Direitos dos Animais. Disponível em: <http://portal.cfmv.gov.br/uploads/direitos.pdf>. Acesso em: 5 nov. 2018.

ORGANIZAÇÃO DAS NAÇÕES UNIDAS PARA AGRICULTURA E ALIMENTAÇÃO. Plano de ação mundial para os recursos genéticos animais e declaração de Interlaken. Brasília: Embrapa Recursos Genéticos e Biotecnologia, 2010.

PÁGINA 22. Grandes produtores de soja, boi e peixe na Amazônia receberam dinheiro de paraísos fiscais. Disponível em: <http://pagina22.com.br/2018/12/08/grandes-produtoresde-soja-e-boi-na-amazonia-receberam-dinheiro-de-paraisosfiscais/?fbclid=IwAR3ME_j00YiIUr7yI3ihFx5m2S5cnT2dixsgZgAYfYfGA8ZIQBkJZ6jiPg>. Acesso em: 18 jan. 2018.

PALEY, W. Works of William Paley D. D.: and an account of the life and writings of the author by the Rev. Edmund Paley. Londres: Longman, 1838.

PARK, M.; SINGER, P. The Globalization of Animal Welfare. Foreign Affairs, 2012. Disponível em: <https://www.foreignaffairs.com/articles/2012-02-13/globalization-animalwelfare >.Acesso em: 12 nov. 2018.

PARRY, J. Gender and slaughter in popular gastronomy. Feminism and Psychology, v. 20, n. 3, p. 381-396, 2010.

PATHAK, H. et al. Carbon footprints of Indian food items. Agriculture, Ecosystems \& Environment, v. 139, n. 1-2, p. 66-73, 15 out. 2010.

PELISSARI, M.; TEIXEIRA, T. M. Ecologia básica. EDUCERE, v. 13, n. 1, p. 7-14, 2013.

PERRY, B. D.; GRACE, D. C. How Growing Complexity of Consumer Choices and Drivers of Consumption Behaviour Affect Demand for Animal Source Foods. EcoHealth, v. 12, n. 4, p. 703-712, 2015.

PHELPS, N. The longest struggle: animal advocacy from Pythagoras to PETA. Nova Iorque: Lantern Books, 2007.

PIGNARRE, P.; STENGERS, I. Capitalist sorcery: breaking the spell. Londrres: Saffron House, 2011.

PIMENTA, J. Desenvolvimento Sustentável E Povos Indígenas: Os Paradoxos De Um Exemplo Amazônico. Anuário Antropológico, v. 2002-2003, p. 115-150, 2004.

PIMENTEL, D.; PIMENTEL, M. Sustainability of meat-based and plant-based diets and the environment. The American Journal of Clinical Nutrition, v. 78, p. 660-663, 2003.

PINTO, G. V. R. Operação carne fraca: uma análise da intervenção estatal no domínio econômico em sua modalidade fiscalizatória. Monografia (Bacharel em Direio) - Centro de Ciências Sociais Aplicadas, Universidade Federal do Rio Grande do Norte, Natal, 2017.

PLATÃO. A República. Rio de Janeiro: Nova Fronteira, 2016. 
POLLAN, M. The omnivores dilemma: a natural history of four meals. Nova Iorque: The Penguin Press, 2006.

PONDÉ, L. F. A carne ética. Disponível em:

<https://www1.folha.uol.com.br/fsp/ilustrad/fq1210200916.htm>. Acesso em: 5 nov. 2018.

POPP, A.; LOTZE-CAMPEN, H.; BODIRSKY, B. Food consumption, diet shifts and associated non- $\mathrm{CO} 2$ greenhouse gases from agricultural production. Global Environmental Change, v. 20, n. 3, p. 451-462, 1 ago. 2010.

PORTAL DO GOVERNO. Projeto "Segunda sem Carne" é vetado por governador. Disponível em: <http://www.saopaulo.sp.gov.br/spnoticias/projeto-segunda-sem-carne-evetado-por-governador/>. Acesso em: 16 jan. 2019.

PORTAL G1. Brasil tem 14\% de vegetarianos e $81 \%$ de adeptos à dieta com carne, diz pesquisa Ibope | Bem Estar | G1. Disponível em:

$<$ https://g1.globo.com/bemestar/noticia/brasil-tem-14-de-vegetarianos-e-81-de-adeptos-adieta-com-carne-diz-pesquisa-ibope.ghtml>. Acesso em: 3 nov. $2018 \mathrm{a}$.

PORTAL G1. Marfrig compra empresa de carne bovina nos EUA por mais de R\$ 3 bilhões. Disponível em: <https://g1.globo.com/economia/noticia/marfrig-adquire-controle-deprocessadora-de-carne-bovina-nos-eua-por-us-969-milhoes.ghtml>. Acesso em: 16 jan. $2019 b$.

PORTILHO, F.; CASTAÑEDA, M. Certificação e confiança face-a-face na feira de produtos orgânicos. IV Encontro Nacional da ANPPAS. Anais...Brasília: ANPPAS, 2008

PORTILHO, F.; CASTAÑEDA, M. Consumo e política: neomodernismo e reflexividade social. XIV Congresso Brasileiro de Sociologia. Anais...Rio de Janeiro: XIV Congresso Brasileiro de Sociologia, 2009. Disponível em:

$<$ http://scholar.google.com/scholar?hl=en\&btnG=Search\&q=intitle:Consumo+e+política:+ne o-modernismo+e+reflexividade+social\#0>. Acesso em 04 out. 2018.

PORTILHO, F.; CASTAÑEDA, M.; CASTRO, I. R. R. DE. A alimentação no contexto contemporâneo: consumo, ação política e sustentabilidade. Ciência \& Saúde Coletiva, v. 16, n. 1, p. 99-106, 2011.

PREECE, R. Awe for the tiger, love for the lamb: a chronicle of sensibility to animals. Vancouver: UBC Press, 2003.

PREECE, R. Sins of the flesh: a history of ethical vegetarian thought. Vancouver: UBC Press, 2009.

PREMALATHA, M. et al. Energy-efficient food production to reduce global warming and ecodegradation: The use of edible insects. Renewable and Sustainable Energy Reviews, v. 15, n. 9, p. 4357-4360, 2011.

PROENÇA, R. P. DA C. Alimentação e globalização: algumas reflexões. Ciência e Cultura, v. 62 , n. 4, p. 43-47, 2010. 
QUEIROZ, C. A.; SOLIGUETTI, D. F. G.; MORETTI, S. L. DO A. As Principais

Dificuldades Para Vegetarianos Se Tornarem Veganos: Um Estudo Com O Consumidor Brasileiro. DEMETRA: Alimentação, Nutrição \& Saúde, v. 13, n. 3, p. 535-554, 2018.

QUEIROZ, T. P.; GOMES, L. G. F. F.; PORTILHO, F. Na Pegada do Ambientalismo: discursos e práticas de consumo. VI Encontro Nacional de Estudos do Consumo. Anais...Rio de Janeiro: VI Encontro Nacional de Estudos do Consumo, 2012.

REA, S. Vegetarian and "Healthy" Diets Could Be More Harmful to the Environment. Disponível em: <https://www.cmu.edu/news/stories/archives/2015/december/diet-andenvironment.html>. Acesso em: 15 out. 2018.

REARDON, S. WHO warns against "post-antibiotic" era. Disponível em: <http://www.nature.com/doifinder/10.1038/nature.2014.15135>. Acesso em: 6 nov. 2018.

REGANOLD, J. P.; WACHTER, J. M. Organic agriculture in the twenty-first century. Nature Plants, v. 2, n. 2, p. 15221, 3 fev. 2016.

REISINGER, A.; CLARK, H. How much do direct livestock emissions actually contribute to global warming? Global Change Biology, v. 24, n. 4, p. 1749-1761, 2018.

REPORTERS WITHOUT BORDERS. Brazil, the country of thirty Berlusconis. Disponível em: <https://rsf.org/en/reports/brazil-country-thirty-berlusconis>. Acesso em: 11 dez. 2018.

RETTMANN, R. Redução do desmatamento na Amazônia por meio da intensificação da pecuária em assentamentos de reforma agrária. Dissertação (Mestrado em Desenvolvimento Sustentável) - Centro de Desenvolvimento Sustentável. Universidade de Brasília, Brasília, 2013.

RIBEIRO, C. D. S. G.; CORÇÃO, M. O consumo de carne no Brasil: entre valores socioculturais e nutricionais. Demetra, v. 8, n. 3, p. 425-438, 2013.

RIBEIRO, D. L. DA S. Impactos ambientais de carne. Dissertação (Mestrado em Educação Ambiental) - Instituto A Vez do Mestre, Universidade Candido Mendes, Rio de Janeiro, 2016.

RIBEIRO, P. M. Certificação e desenvolvimento de marcas como estratégia de diferenciação de produtos: o caso da cadeia agroindustrial da carne bovina. Tese (Doutorado em Engenharia de Produção) - Departamento de Engenharia de Produção da Universidade Federal de São Carlos, São Carlos, 2008.

RICKLEFS, R. E. A economia da natureza. Rio de Janeiro: Guanabara Koogan, 2010.

RIFKIN, J. Beyond beef: the rise and fall of the cattle culture. Nova Iorque: Plume, 1993.

RIVERO, S. et al. Pecuária e desmatamento: Uma análise das principais causas diretas do desmatamento na Amazônia. Nova Economia, v. 19, n. 1, p. 41-66, 2009.

ROBBINS, J. Diet for a new America: how your food choices affect your health, your happiness, and the future of life on Earth. Novato: Hj Kramer, 2012. 
ROÇA, R. DE O. Composição química da carne. Disponível em:

<http://www.fca.unesp.br/Home/Instituicao/Departamentos/Gestaoetecnologia/Teses/Roca10 2.pdf>. Acesso em: 1 nov. 2018.

ROJAS-DOWNING, M. M. et al. Climate Risk Management Climate change and livestock : Impacts , adaptation, and mitigation. Climate Risk Management, v. 16, p. 145-163, 2017.

ROSENFELD, D. L.; BURROW, A. L. Vegetarian on purpose: Understanding the motivations of plant-based dieters. Appetite, v. 116, 2017.

ROTHGERBER, H. A comparison of attitudes toward meat and animals among strict and semi-vegetarians. Appetite, v. 72, p. 98-105, 2014.

ROWLAND, M. P. Millennials Are Driving The Worldwide Shift Away From Meat. Disponível em:

<https://www.forbes.com/sites/michaelpellmanrowland/2018/03/23/millennials-move-awayfrom-meat/\#1a7b7886a4a4>. Acesso em: 4 nov. 2018.

RUBY, M. B. Vegetarianism. A blossoming field of study. Appetite, v. 58, p. 141-150, 2012.

SABATÉ, J.; SORET, S. Sustainability of plant-based diets: back to the future. The American Journal of Clinical Nutrition, v. 100, n. suppl_1, p. 476S-482S, 1 jul. 2014.

SACHS, I. Estratégias de transição para o século XXI. In: BURSZTYN, M. (Ed.). Para Pensar o Desenvolvimento Sustentável. São Paulo: Brasiliense, 1993.

SALONEN, A. O.; HELNE, T. T. Vegetarian diets: a way towards a sustainable society. Journal of Sustainable Development, v. 5, n. 6, p. 10-24, 2012.

SANTOS, C. A. B.; FLORÊNCIO, R. R. Breve Histórico Das Relações Homem-Ambiente Presentes Na Entomofagia E Entomoterapia. Polêm!ca, v. 12, n. 2, p. 786-798, 2013.

SANTOS, J. P. M. DOS; BELEZA, W. L. F. Princípio da precaução. Disponível em: $<$ http://ambitojuridico.com.br/site/?n_link=revista_artigos_leitura\&artigo_id=15600\&revista_ caderno=5>. Acesso em: 20 nov. 2018.

SANTOS, G. M.; SANTOS, A. C. M. Sustentabilidade da pesca na Amazônia. Estudos Avançados, v. 19, n. 54, p. 165-182, 2005.

SAPKOTA, A. R. et al. Poultry farms that transitioned to organic practices. Environmental Health Perspectives, v. 119, n. 11, p. 1622-1629, 2011.

SAWE, B. E. Countries With The Highest Rates Of Vegetarianism. Disponível em: $<$ https://www.worldatlas.com/articles/countries-with-the-highest-rates-ofvegetarianism.html>. Acesso em: 15 jan. 2019.

SCHLINDWEIN, M. M.; KASSOUF, A. L. Análise da influência de alguns fatores socioeconômicos e demográficos no consumo domiciliar de carnes no Brasil. Revista de Economia e Sociologia Rural, v. 44, n. 3, p. 549-572, set. 2006. 
SCHUCK, C.; RIBEIRO, R. Comendo o planeta: impactos ambientais da criação e consumo de animais. São Paulo: Vesper AMB, 2015.

SEARCHINGER, T. et al. Creating a sustainable food future: a menu of solutions to feed nearly 10 billion people by 2050. Washington D.C.: World Resources Institute, 2018.

SHERMAN, H. C. Permanent gains from the food conservation movement. Columbia University Quaterly, v. 21, n. 1, p. 1-14, 1919.

SHINDELL, D. T. et al. Improved attribution of climate forcing to emissions. Science, v. 326, n. 5953 , p. $716-8,30$ out. 2009.

SILVA, D. R. DA. Los efectos de la operación "carne débil" en la imagen de Brasil. Revista Estratégia Organizacional, v. 5, n. 1, p. 49-58, 2016.

SILVA, J. G. DA; RUVIARO, C. F.; FERREIRA-FILHO, J. B. DE S. Livestock intensification as a climate policy: Lessons from the Brazilian case. Land Use Policy, v. 62, p. 232-245, 1 mar. 2017.

SINGER, P. Libertação Animal. Porto Alegre: Lugano, 2004.

SIQUEIRA, A. DE. Ética e educação ambiental no consumo de produtos de origem animal. REMEA, v. 1, p. 318-330, 2014.

SLYWITCH, E. Virei vegetariano, e agora? São Paulo: Editora Alaúde, 2010.

SLYWITCH, E. Guia alimentar de dietas vegetarianas. Sociedade Vegetariana Brasileira, p. $1-66,2012$.

SMITH, A. The wealth of nations. Nova Iorque: Bantam Classics, 2007.

SMITH, P. et al. Greenhouse gas mitigation in agriculture. Philosophical transactions of the Royal Society of London. Series B, Biological sciences, v. 363, n. 1492, p. 789-813, 27 fev. 2008.

SMITH, P. et al. How much land-based greenhouse gas mitigation can be achieved without compromising food security and environmental goals? Global Change Biology, v. 19, n. 8, p. 2285-2302, 1 ago. 2013.

SMITH, P. et al. Agriculture, Forestry and Other Land Use (AFOLU). In: EDENHOFER, O. et al. (Eds). Climate Change 2014: Mitigation of Climate Change - Working Group III Contribution to the Fifth Assessment Report of the Intergovernmental Panel on Climate Change. Nova Iorque: Cambridge University Press, 2014.

SOCIEDADE VEGETARIANA BRASILEIRA. Vegetarianismo. Disponível em: <https://www.svb.org.br/vegetarianismo1/o-que-e>. Acesso em: 04 nov. 2018a.

SOCIEDADE VEGETARIANA BRASILEIRA. Mercado vegetariano. Disponível em: $<$ https://www.svb.org.br/vegetarianismo1/mercado-vegetariano>. Acesso em: 04 nov. 2018b. 
SOCIEDADE VEGETARIANA BRASILEIRA. Opção Vegana. Disponível em:

<http://opcaovegana.svb.org.br/\#a-campanha>. Acesso em: 16 jan. 2018c.

SOCIETÀ SCIENTIFICA DI NUTRIZIONE VEGETARIANA. Making the Change to a Vegetarian Diet. Disponível em:

<https://www.scienzavegetariana.it/nutrizione/VNPGI_IVD/Changetoavegndiet.html>.

Acesso em: 13 dez. 2018.

SORDI, C. De carcaças e máquinas de quatro estômagos: estudo das controvérsias sobre o consumo e a produção de carne no Brasil. Dissertação (Mestrado em Antropologia Social) Universidade Federal do Rio Grande do Sul, Porto Alegre, 2013.

SORVINO, C. Tyson Invests In Lab-Grown Protein Startup Memphis Meats, Joining Bill Gates And Richard Branson. Disponível em:

$<$ https://www.forbes.com/sites/chloesorvino/2018/01/29/exclusive-interview-tyson-invests-inlab-grown-protein-startup-memphis-meats-joining-bill-gates-and-richardbranson/\#7786c0b13351>. Acesso em: 23 nov. 2018.

SOUZA, A. DE M. et al. Alimentos mais consumidos no Brasil: Inquérito Nacional de Alimentação 2008-2009. Revista de Saúde Pública, v. 47, p. 190s-199s, fev. 2013.

SOUZA, R. O. C. Vegetarianismo ambiental. VIII Encontro Nacional da Associação Nacional da Pós-Graduação. Anais... Natal: ENNANPAS, 2017.

SPENCER, C. The heretic's feast: a history of vegetarianism. Líbano: University Press of New England, 1996.

SPRINGMANN, M. et al. Analysis and valuation of the health and climate change cobenefits of dietary change. Proceedings of the National Academy of Sciences of the United States of America, v. 113, n. 15, p. 4146-4151, 2016.

SPRINGMANN, M. et al. Options for keeping the food system within environmental limits. Nature, v. 562, n. 7728, p. 519-525, 10 out. 2018.

STAVE, K. A.; KOPAINSKY, B. A system dynamics approach for examining mechanisms and pathways of food supply vulnerability. Journal of Environmental Studies and Sciences, v. 5, n. 3, p. 321-336, 2015.

STEHFEST, E. et al. Climate benefits of changing diet. Climatic Change, v. 95, n. 1-2, p. 83-102, 4 jul. 2009.

STRATHERN, M. Partial connections. Walnut Creek: AltaMira Press, 2004.

SUBRAMANIAM, M. An introduction to the concept of vegetarianism amongs hindus in Malaysia. Jurnal Pengajian India, v. 10, n. 1, p. 51-60, 2011.

SUNDRUM, A. Organic livestock farming: A critical review. Livestock Production Science, v. 67, n. 3, p. 207-215, 1 jan. 2001.

TAKEUTI, D.; OLIVEIRA, J. M. Para além dos aspectos nutricionais: uma visão ambiental 
do sistema alimentar. Campinas, v. 20, n. 2, p. 194-203, 2013.

TARDE, G. Monadologia e sociologia. Monadologia e sociologia: e outros ensaios, p. 51$131,2007$.

TAVARES, A. P. Comida afetiva: uma expresão de gosto, hospitalidade e memória. Dissertação (Mestrado Profissional em Turismo) - Centro de Excelência em Turismo, Universidade de Brasília, Brasília, 2018.

TAYLOR, A.-L. Rise of the "semi-vegetarians". Disponível em: <http://www.bbc.co.uk/food/0/19294585>. Acesso em: 10 dez. 2018.

TEIXEIRA, J. C. Saúde ambiental. Apostila (Curso de Engenharia Sanitária e Ambiental) Universidade Federal de Juiz de Fora, Juiz de Fora, 2012.

THE GUARDIAN. Meat tax 'inevitable' to beat climate and health crises, says report. Disponível em: <https://www.theguardian.com/environment/2017/dec/11/meat-tax-inevitableto-beat-climate-and-health-crises-says-report>. Acesso em: 16 jan. 2019.

THE LOCAL. One in ten Swedes is vegetarian: survey. Disponível em: <https://www.thelocal.se/20140321/one-in-ten-swedes-is-vegetarian-survey>. Acesso em: 15 jan. 2019.

THE VEGAN SOCIETY. Definition of veganism. Disponível em: <https://www.vegansociety.com/go-vegan/definition-veganism>. Acesso em: 22 out. 2018.

THÉRY, H. et al. Atlas do trabalho escravo no Brasil. São Paulo: Amigos da Terra Amazônia Brasileira, 2012.

THÉRY, H.; MELLO, N. A. DE. DIVERSIDADES E MOBILIDADES DA AGRICUlTURA BRASILEIRA. Cadernos de Ciência \& Tecnologia, v. 22, n. 1, p. 21-36, 2005.

THOMS, U. Vegetarianism, meat, and life reform in early twentieth-century Germany and their fate in the "Third Reich". In: Meat, medicine and human health in the twentieth century. Abingdon: Routledge, 2010.

THORNTON, P. K.; HERRERO, M. Potential for reduced methane and carbon dioxide emissions from livestock and pasture management in the tropics. Proceedings of the National Academy of Sciences of the United States of America, v. 107, n. 46, p. 19667-72, 16 nov. 2010.

TILMAN, D.; CLARK, M. Global diets link environmental sustainability and human health. Nature, v. 515, n. 7528, p. 518-522, 2014.

TOLENTINO, M.; ROCHA-FILHO, R. C. A química no efeito estufa. Química Nova na Escola, n. 8, 1998.

TOM, M. S.; FISCHBECK, P. S.; HENDRICKSON, C. T. Energy use, blue water footprint, and greenhouse gas emissions for current food consumption patterns and dietary 
recommendations in the US. Environment Systems and Decisions, v. 36, n. 1, p. 92-103, 24 mar. 2015.

TOORN, S. I. AAN DEN; BROEK, M. A. VAN DEN; WORRELL, E. Decarbonising meat: Exploring greenhouse gas emissions in the meat sector. Energy Procedia, v. 123, p. 353360, 2017.

TOUZEAU, A. et al. Diet of ancient Egyptians inferred from stable isotope systematics. Journal of Archaeological Science, v. 46, n. 1, p. 114-124, 2014.

TUOMISTO, H. L.; MATTOS, M. J. T. DE. Environmental impacts of cultured meat production. Environmental Science and Technology, v. 45, n. 14, p. 6117-6123, 2011.

TUSO, P. J. et al. Nutritional update for physicians: plant-based diets. The Permanente Journal, v. 17, n. 2, p. 61-66, 2013.

UNIÃO VEGETARIANA INTERNACIONAL. Definitions. Disponível em: <https://ivu.org/portuguese/faq/definitions.html>. Acesso em: 2 nov. 2018.

UNITED NATIONS. World population projected to reach 9.8 billion in 2050 , and 11.2 billion in 2100. Disponível em:

$<$ https://www.un.org/development/desa/en/news/population/world-population-prospects2017.html>. Acesso em: 5 dez. 2018.

UNITED NATIONS ENVIRONMENT PROGRAMME. Growing greenhouse gas emissions due to meat production. Environmental Development, v. 5, p. 156-163, 2013.

UNITED NATIONS FRAMEWORK CONVENTION ON CLIMATE CHANGE. Reporting requirements. Disponível em: <https://unfccc.int/process-and-meetings/transparency-andreporting/reporting-and-review-under-the-convention/greenhouse-gas-inventories-annex-iparties/reporting-requirements>. Acesso em: 1 dez. 2018.

VALE, P. M.; ANDRADE, D. C. Comer carne e salvar a Amazônia? A produtividade da pecuária em Rondônia e sua relação com o desmatamento. Estudos Sociedade e Agricultura, v. 20, n. 2, p. 381-408, 2012.

VARGAS, E. V. Gabriel Tarde e a diferença infinitesimal. In: Monadologia e Sociologia e Outros Ensaios. São Paulo: Cosac Naify, 2007.

VEIGA, J. E. DA. Indicadores de Sustentabilidade. Estudos Avançados, v. 24, n. 68, p. 39$52,2010$.

VEIGA, J. E. DA. Âmago Da Sustentabilidade. Estudos Avançados, v. 28, n. 82, p. 7-24, 2014.

VENTURINI, T. Diving in magma: how to explore controversies with actor-network theory. Public Understanding of Science, v. 19, n. 3, p. 258-273, 2010a.

VENTURINI, T. Building on faults: how to represent controversies with digital methods. Public Understanding of Science, v. 21, n. 7, p. 796-812, 2010b. 
VENTURINI, T. Designing Controversies and their Publics. Design Issues, v. 29, n. 4, p. 17$30,2015$.

VERBEKE, W.; SANS, P.; VAN LOO, E. J. Challenges and prospects for consumer acceptance of cultured meat. Journal of Integrative Agriculture, v. 14, n. 2, p. 285-294, 2015.

VERMEULEN, S. J.; CAMPBELL, B. M.; INGRAM, J. S. I. Climate Change and Food Systems. Annual Review of Environment and Resources, v. 37, n. 1, p. 195-222, 21 nov. 2012.

VIEIRA, I. Para especialistas, churrasco de domingo é vilão do aquecimento global. Disponível em: <http://agenciabrasil.ebc.com.br/geral/noticia/2016-11/para-especialistaschurrasco-de-domingo-e-vilao-do-aquecimento-global>. Acesso em: 18 jan. 2019.

VINNARI, M.; VINNARI, E. A Framework for Sustainability Transition: The Case of PlantBased Diets. Journal of Agricultural and Environmental Ethics, v. 27, n. 3, 2014.

VRANKEN, L. et al. Curbing global meat consumption: Emerging evidence of a second nutrition transition. Environmental Science \& Policy, v. 39, p. 95-106, maio 2014.

WALDMAN, M. Recursos hídricos: impactos da produção de alimentos e dos resíduos orgânicos. São Paulo: Kotev, 2003.

WALDMAN, M. De onde vem o lixo produzido no mundo. Disponível em: $<$ https://www.estadao.com.br/infograficos/sustentabilidade,de-onde-vem-o-lixo-produzidono-mundo,235040>. Acesso em: 16 nov. 2018.

WALTERS, K. S. Vegetarianism: a guide for the perplexed. Londres: Bloomsbury Academic, 2012.

WEBER, C. L.; MATTHEWS, H. S. Food-Miles and the Relative Climate Impacts of Food Choices in the United States. Environmental Science \& Technology, v. 42, n. 10, p. 35083513, maio 2008.

WEISS, B. Configuring the authentic value of real food: Farm-to-fork, snout-to-tail, and local food movements. American Ethnologist, v. 39, n. 3, p. 614-626, 2012.

WEISSHEIMER, M. Todas as opressões estão conectadas. Veganismo é uma extensão lógica da luta anti-opressão. Disponível em: <https://www.sul21.com.br/ultimasnoticias/geral/2018/04/todas-as-opressoes-estao-conectadas-veganismo-e-uma-extensaologica-da-luta-anti-opressao/>. Acesso em: 2 maio. 2018.

WHERRY, E. Does a low-protein diet produce racial inferiority? Science, v. 38, n. 970, p. 156-158, 1913.

WILKIE, R. Livestock/deadstock: working with farm animals from birth to slaughter. Filadélfia: Temple University Press, 2010.

WILlET, M. How We Eat Meat Around The World. Disponível em: 
<https://www.businessinsider.com/how-we-eat-meat-around-the-world-2014-1>. Acesso em: 16 jan. 2019.

WILLIAMS, H. The ethics of diet: a catena of authorities deprecatory of the practice of flesh-eating. Champaign: University of Illinois Press, 2003.

WIRSENIUS, S. Efficiencies and biomass appropriation of food commodities on global and regional levels. Agricultural Systems, v. 77, n. 3, p. 219-255, 2003.

WORLDOMETERS. World Population. Disponível em:

<http://www.worldometers.info/world-population/>. Acesso em: 15 nov. 2018.

YADAV, Y.; KUMAR, S. The food habits of a nation. Disponível em:

<https://www.thehindu.com/todays-paper/the-food-habits-of-a-nation/article3089973.ece>. Acesso em: 15 jan. 2019.

YASBEK, M. Fome Zero: uma política social em questão. Saúde e Sociedade, v. 12, n. 1, p. 43-50, 2003.

ZANIRATO, S. H.; ROTONDARO, T. Consumo, um dos dilemas da sustentabilidade. Estudos Avançados, v. 30, n. 88, p. 77-92, 2016.

ZEN, S. DE et al. Pecuária de corte brasileira: impactos ambientais e emissões de gases efeito estufa (GEE). Piracicaba: Centro de Estudos Avançados em Economia Aplicada, 2008. 